\title{
Geology of the Payette National Forest and Vicinity, West-Central Idaho
}
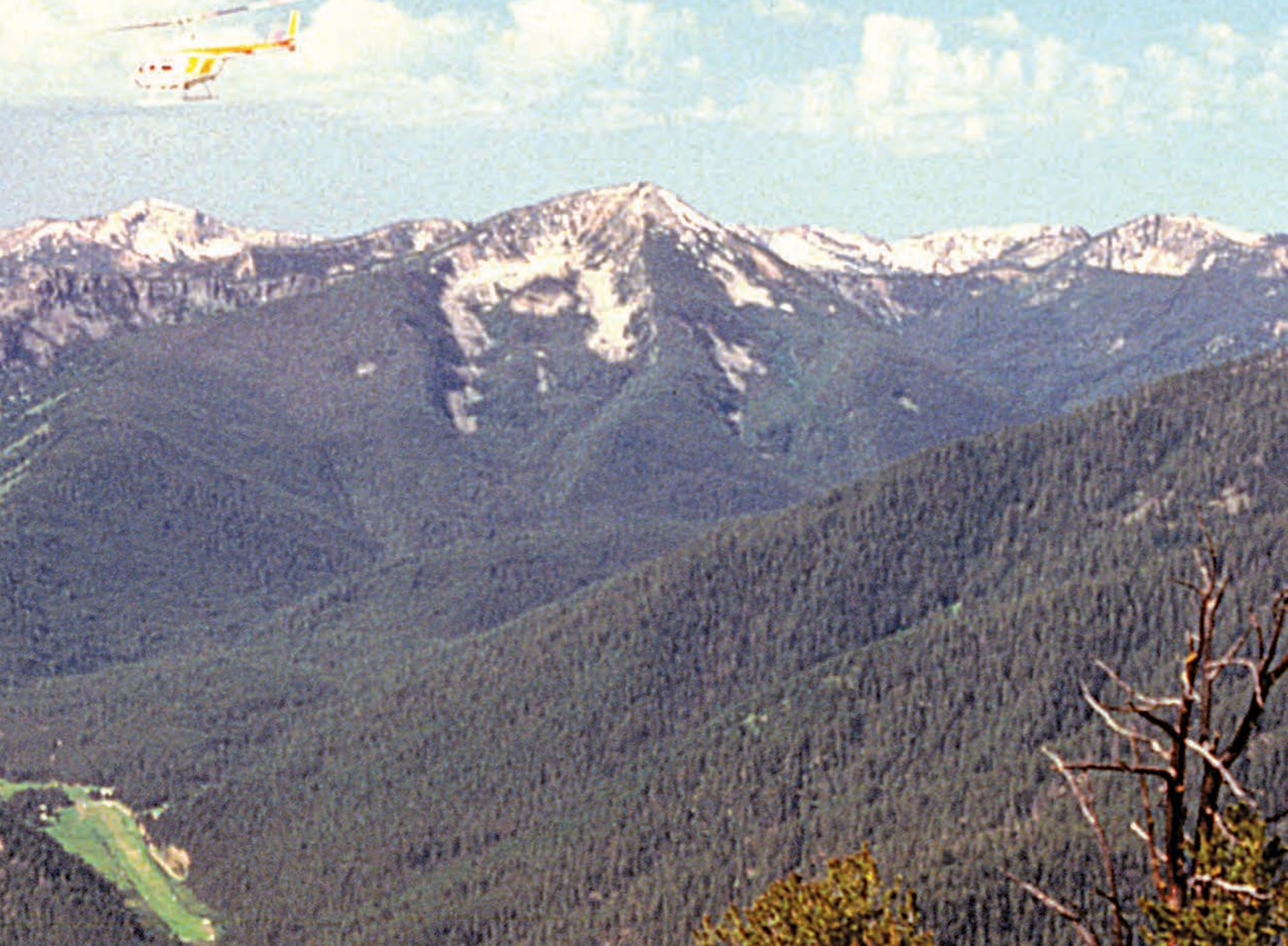

Professional Paper 1666

Version 1.1, April 2021

Supersedes USGS Miscellaneous Geologic nvestigations:

Map I-2599 and the GIS datain USGS Open Elle, Report 98-219-B.

U.S. Department of the Interiof

U.S. Geological Survey

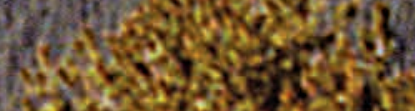
ist

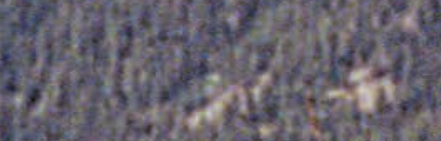
1) 
Cover. View to south of Big Creek airstrip and Edwardsburg in midground from McFadden Point. North end of hogback at airstrip is dated location of the Neoproterozoic Hogback Rhyolite Member of the Edwardsburg Formation, one of the herein named and dated formations of the Windermere Supergroup. Western and northern edge of Thunder Mountain caldera in peaks to left and middle of Profile Gap, and roof pendants of Windermere Supergroup floating above Cretaceous granite in peaks to right. 
Geology of the Payette National Forest and Vicinity, West-Central Idaho 


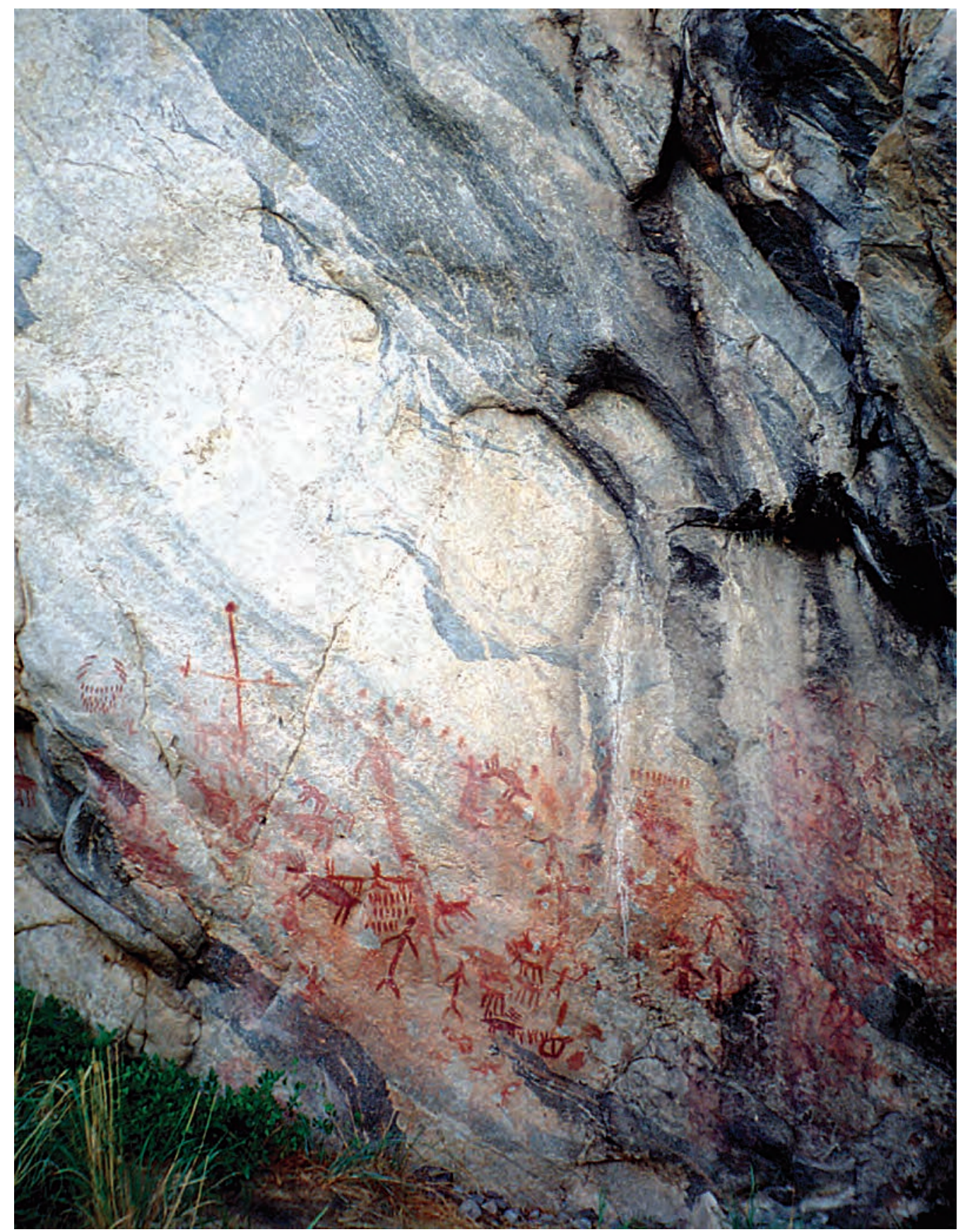

Frontispiece. A first publication on the Mesoproterozoic biotite gneiss migmatite (Ygn) of the Middle Fork Salmon River (date unknown). 


\section{Geology of the Payette National Forest and Vicinity, West-Central Idaho}

By Karen Lund

Chapter A

Geologic Setting of the Payette National Forest, West-Central Idaho

By Karen Lund

Chapter B

Description of Map Units for the Geologic Map of the

Payette National Forest, West-Central Idaho

By Karen Lund

Chapters $A$ and $B$ are issued as a single volume and are not available separately

Professional Paper 1666-A-B

Version 1.1, April 2021

Supersedes USGS Miscellaneous Geologic Investigations Map I-2599 and

the GIS data in USGS Open-File Report 98-219-B 


\section{U.S. Geological Survey, Reston, Virginia First release: 2004 Revised: April 2021 (ver. 1.1)}

For sale by U.S. Geological Survey, Information Services Box 25286, Denver Federal Center

Denver, CO 80225

For more information about the USGS and its products: Telephone: 1-888-ASK-USGS

World Wide Web: https://www.usgs.gov/

Any use of trade, product, or firm names in this publication is for descriptive purposes only and does not imply endorsement by the U.S. Government.

Although this report is in the public domain, permission must be secured from the individual copyright owners to reproduce any copyrighted materials contained within this report.

Suggested citation:

Lund, K., 2004, Geology of the Payette National Forest and vicinity, west-central Idaho (ver. 1.1, April 2021):

U.S. Geological Survey Professional Paper 1666-A, -B, 89 p., https://doi.org/10.3133/pp1666. [Supersedes USGS

Miscellaneous Geologic Investigations Map I-2599 and the GIS data in USGS Open-File Report 98-219-B.] 


\section{Geologic Setting of the Payette National Forest, West-Central Idaho}

By Karen Lund

Chapter A of

Geology of the Payette National Forest and Vicinity,

West-Central Idaho

By Karen Lund

Professional Paper 1666-A

Version 1.1, April 2021

Supersedes USGS Miscellaneous Geologic Investigations Map I-2599 and the GIS data in USGS Open-File Report 98-219-B 



\section{Contents}

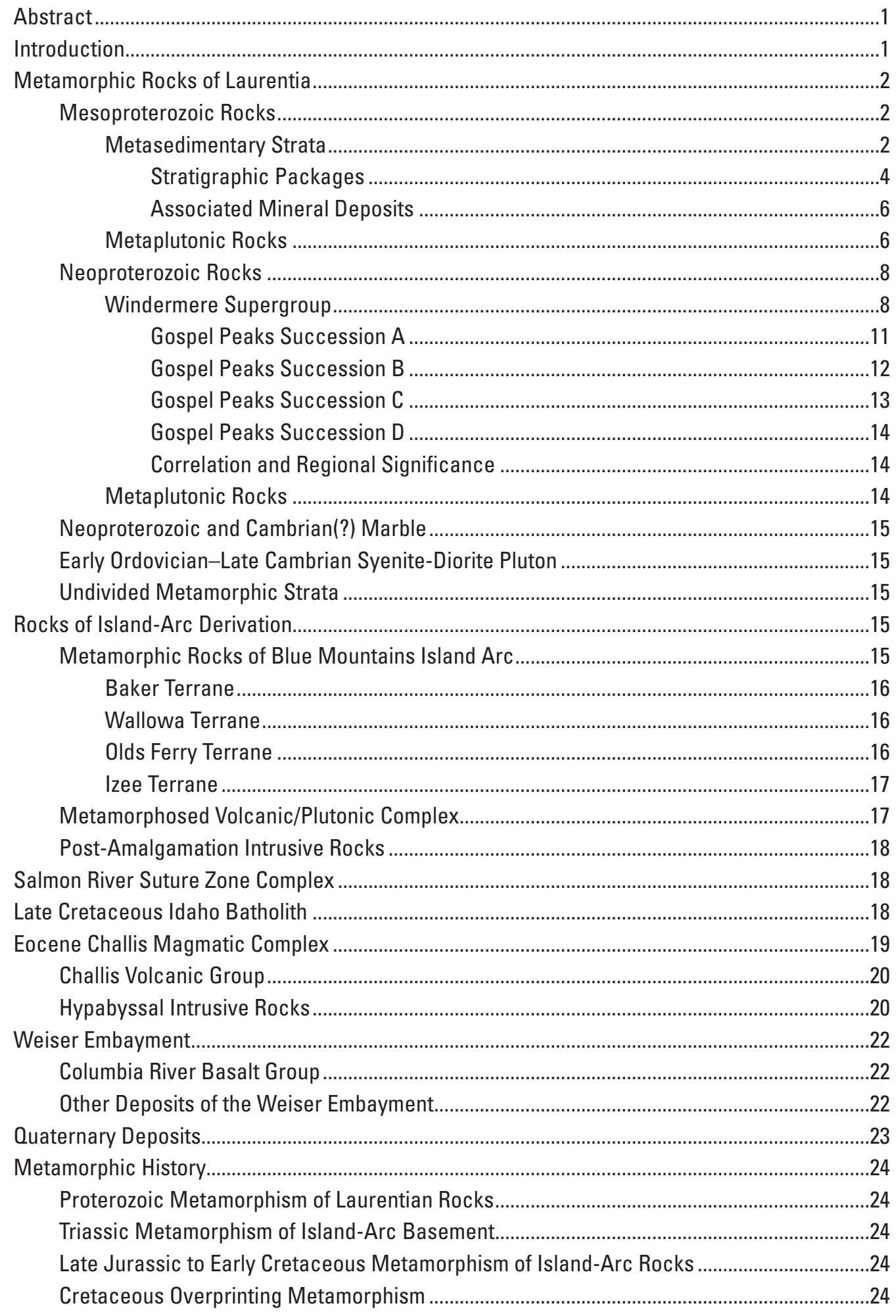


Structure

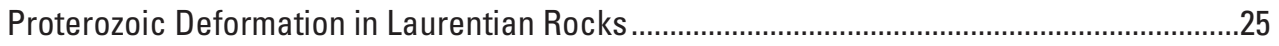

Triassic Deformation in the Wallowa Terrane...................................................................25

Late Middle Jurassic to Early Cretaceous(?) Deformation in Island-Arc Rocks .....................26

Late Jurassic to Early Cretaceous Deformation in Island-Arc Rocks ....................................26

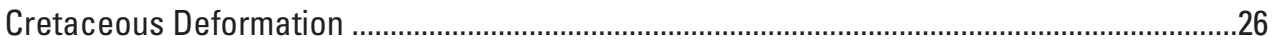

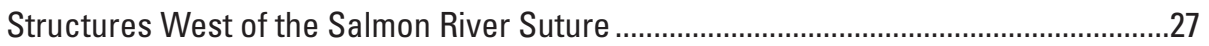

Thrust Faulting and Folding East of the Salmon River Suture ........................................28

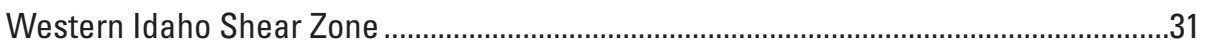

Geometry of Cretaceous Deformation ......................................................................32

Shear Zones and Related Mineral Deposits East of the Salmon River Suture................32

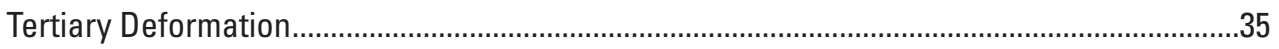

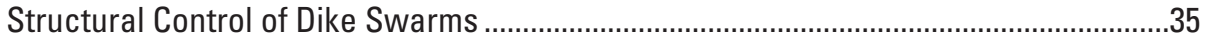

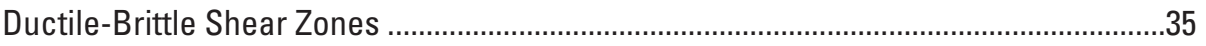

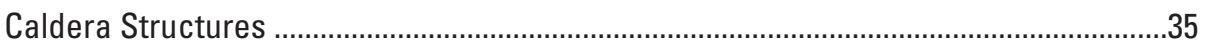

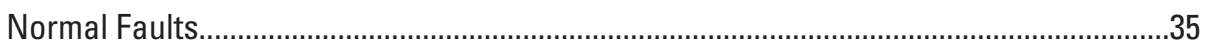

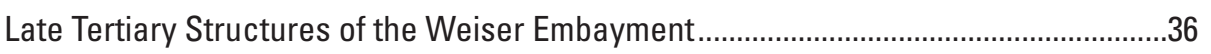

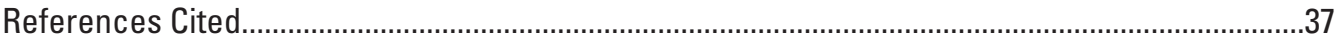

\section{Plates}

[In pocket]

1. Geologic map of the western part of the Payette National Forest, west-central Idaho.

2. Geologic map of the eastern part of the Payette National Forest, west-central Idaho.

\section{Figures}

A1-4. Maps showing:

A1. Geographic extent of Payette and Salmon National Forests .....................................

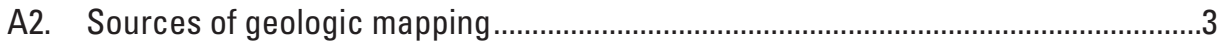

A3. Generalized geology of Payette National Forest and vicinity ....................................

A4. Mining districts in Payette National Forest and vicinity ..........................................

A5. Regional correlation diagram for Neoproterozoic strata of northern

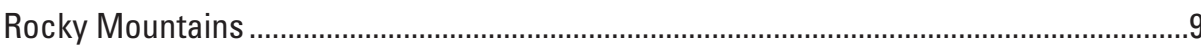

A6. Map showing locations of type sections of Neoproterozoic units named and described in this study.

A7-12. Photographs showing:

A7. Flat dikes (sills) of Eocene rhyolite cutting Late Cretaceous granite ......................21

A8. Contrasting metamorphic and deformation features across

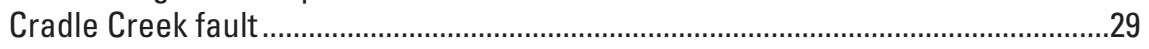

A9. Asymmetric folds in calc-silic ate gneiss of Missouri Ridge Formation ...................30

A10. Overturned crossbedding in quartzite of Square Mountain Formation...................31

A11. Deformation in metamorphosed volcanic/plutonic complex ....................................33

A12. Shearing and mylonitization in Late Cretaceous granite ............................................34

\section{Table}

Al. Geochemical data for volcanic rocks of Neoproterozoic Edwardsburg Formation........11 


\title{
Geologic Setting of the Payette National Forest, West-Central Idaho
}

\author{
By Karen Lund
}

\section{Abstract}

Before the Late Cretaceous, the eastern and western parts of the geologically complex Payette National Forest, as divided by the Salmon River suture, had fundamentally different geologic histories. The eastern part is underlain by Mesoproterozoic to Cambrian(?) rocks of the Laurentian (Precambrian North American) continent. Thick Mesoproterozoic units, which are at least in part equivalent in age to the Belt Supergroup of northern Idaho and western Montana, underwent Mesoproterozoic metamorphic and deformational events, including intrusion of Mesoproterozoic plutons. During the Neoproterozoic to early Paleozoic, the western edge of Laurentia was rifted. This event included magmatism and resulted in deposition of rift-related Neoproterozoic to Lower Cambrian(?) volcanic and sedimentary rocks above Mesoproterozoic rocks. The western part of the forest is underlain by upper Paleozoic to lower Mesozoic island-arc volcanic and sedimentary rocks. These rocks comprise four recognized island-arc terranes that were amalgamated and intruded by intermediate-composition plutons, probably in the Late Jurassic and Early Cretaceous, and then sutured to Laurentia along the Salmon River suture in the Late Cretaceous.

The Salmon River suture formed as a right-lateral, transpressive fault. The metamorphic grade and structural complexity of the rocks increase toward the suture from both sides, and geochemical signatures in crosscutting plutonic rocks abruptly differ across the crustal boundary. Having been reactivated by younger structures, the Salmon River suture forms a north-trending topographic depression along Long Valley, through McCall, to the Goose Creek and French Creek drainages.

During the last stages of metamorphism and deformation related to the suture event, voluminous plutons of the Idaho batholith were intruded east of the suture. An older plutonic series is intermediate in composition and preserved as elongated and deformed bodies near the suture and as parts of roof pendants to younger intrusions to the east. A younger magma series consists of undeformed, marginally peraluminous plutons that formed east of the suture after accretion.

After suture-related compression, crustal extension resulted in voluminous volcanic and plutonic rocks of the Eocene Challis magmatic complex on the east side of the forest. Extension, from the Late Cretaceous to post-Miocene, uplifted the area of the Idaho batholith relative to the western part of the forest and formed dominant highlands along the Snake River. Extensional basins also formed such that, in the Miocene, the Columbia River Basalt Group and related basaltic lavas flowed over most of the lower elevations on the western side of the forest and redirected erosional debris into north-trending, fault-controlled drainages and young sedimentary basins.

\section{Introduction}

The Payette National Forest (hereafter referred to as the forest) covers 2.3 million acres, making up most of west-central Idaho (fig. A1). For the most part, the area is heavily forested and fairly inaccessible. The eastern one-third and northwestern one-sixth of the forest are designated "Wilderness Areas" and have no road access. A significant amount of the center of the forest is classified as "Roadless Areas." Geologic study of the forest was requested by the U.S. Forest Service for land-use planning purposes.

This geologic map (pls. 1 and 2; supersedes Lund and others, 1998) is a compilation of both previously published and new data (fig. A2). Before this study, large parts of the area had no previous geologic studies or had only reconnaissance geologic mapping. Because of difficult access and time constraints, the geologic mapping of the wilderness areas consists of generalized reconnaissance mapping and, although improved in places for this study, remains primarily compiled from previous sources. Where it was possible to field check and update during this study, the previous mapping in the eastern part of the forest commonly was found to be very unsatisfactory. However, other areas of the forest, particularly in the west half, had more accurate and available geologic information (fig. A2).

Geologically, the forest has a unique location, spanning the abrupt island-arc-continent boundary known as the Salmon River suture (fig. A3); rocks on either side of it had very different origins and histories before suturing. Older Laurentian (Precambrian and Paleozoic North American) continent on the east side of the forest is separated by the suture from allochthonous oceanic rocks on the west side. The stratigraphy and history of the continental rocks must be pieced together from exposures in roof pendants because the eastern side of the area is in the Idaho batholith province and is largely underlain by 
plutonic rocks of four different Mesoproterozoic to Eocene intrusive episodes. Oceanic rocks on the west side are from at least four island-arc terranes and include plutons that intruded after the terranes were amalgamated but before their accretion to Laurentia. Although both oceanic and continental terranes underwent deformation and metamorphism earlier and independently, the most pervasive deformation and metamorphism in the forest resulted from accretionary processes that ultimately resulted in suturing the island-arc rocks to Laurentia; these effects decrease in intensity away from the suture. The early history of the suture itself is obscured by Cretaceous plutons that record only the younger history of the zone. The Weiser embayment of the Columbia River Basalt Group is in the western part of the area, where basalt flows were confined by uplifts related to Tertiary block faulting (fig. A3). Tertiary faulting is also responsible for the control of late Tertiary sedimentation and of most present-day drainage patterns in the forest.

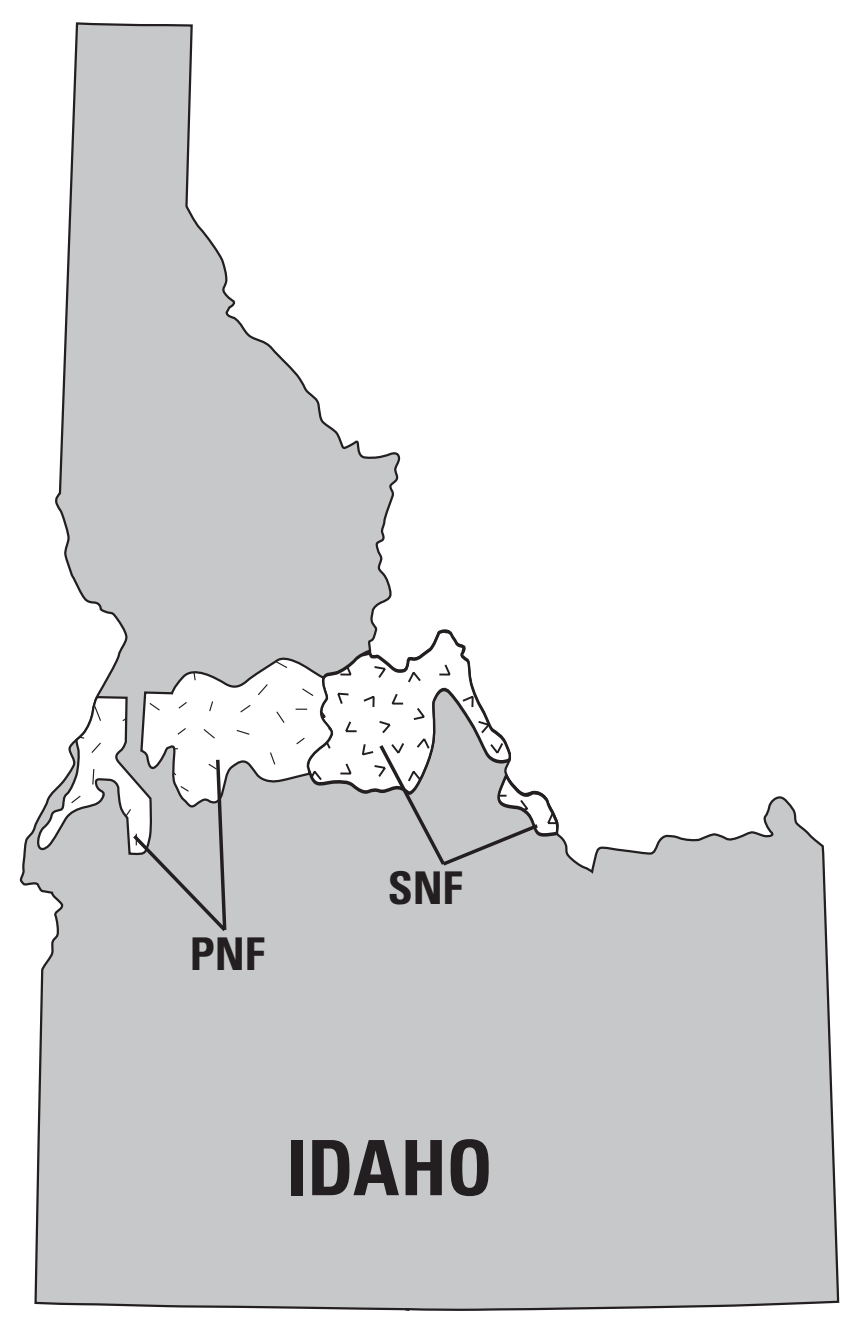

Figure A1. Geographic extent of Payette (PNF) and Salmon (SNF) National Forests, west-central Idaho.

\section{Metamorphic Rocks of Laurentia}

The metamorphic rocks of Laurentian derivation are preserved as roof pendants, migmatitic gneisses, and screens in the plutonic rocks of the Idaho batholith. Four major roof pendants are named Marshall Mountain, Stibnite, Big Creek, and mouth of the Middle Fork (fig. A3). Several large inclusions, at Burgdorf Summit, Sheepeater Mountain, Middle Fork of the Salmon River, and surrounding the more intact roof pendants, are present in the forest where rocks above and within plutons of the Idaho batholith are preserved (pl. 2). Metamorphic rocks of the southern part of the Gospel Peaks and Buffalo Hump roof pendants (northwestern pl. 2; northern fig. A3) are also discussed in this report. Roof pendants are large and coherent enough for individual units to be traced and mapped. Zones of migmatitic gneiss are exposed primarily along the Salmon River where Cretaceous and Mesoproterozoic magmas intruded into high-grade, partially melted terrigenous rocks, possibly because of exposure of deeper crustal levels through a combination of thrust fault exposure and normal-fault block tilting. Screens predominate near the Salmon River suture where metamorphic rocks are highly deformed together with Cretaceous plutonic rocks. In the screens and migmatitic gneiss zones, primary features have been replaced by dynamothermal and melt features, respectively, and lithodemic units are difficult to map.

Geologic mapping of the forest and nearby areas has demonstrated that there are two major age groups represented in these discontinuous exposures of metamorphic rocks of Laurentian derivation. A band of Mesoproterozoic rocks crops out in a northwest-southeast trend across the eastern part of plate 2 (central and eastern fig. A3). A parallel band of Neoproterozoic metamorphic rocks and minor Lower Cambrian(?) metamorphic rocks lies southwest of the older rocks.

\section{Mesoproterozoic Rocks}

\section{Metasedimentary Strata}

Recent mapping (Lund, 1984; Lewis and others, 1990; Lund and Esparza, 1990; Evans and Green, 2003; this study) has significantly upgraded previous generalized lithologic mapping of metamorphic rocks across central Idaho. Because of these efforts, tectonostratigraphic packages are traced across the State and most of the metamorphic rocks are correlated with known stratigraphic units. In general, the Mesoproterozoic strata of central Idaho are equivalent to rocks of the Mesoproterozoic Belt Supergroup of northern and central Montana and northern Idaho. However, the relatively better studied Mesoproterozoic strata of eastern Idaho and adjacent southwestern Montana are not conclusively correlated with specific units of the Belt Supergroup and probably originated in somewhat different settings and environments (Tysdal, 2000). Strata in the forest are probably most closely related to those of eastern Idaho rather than to the Belt Supergroup farther north. 


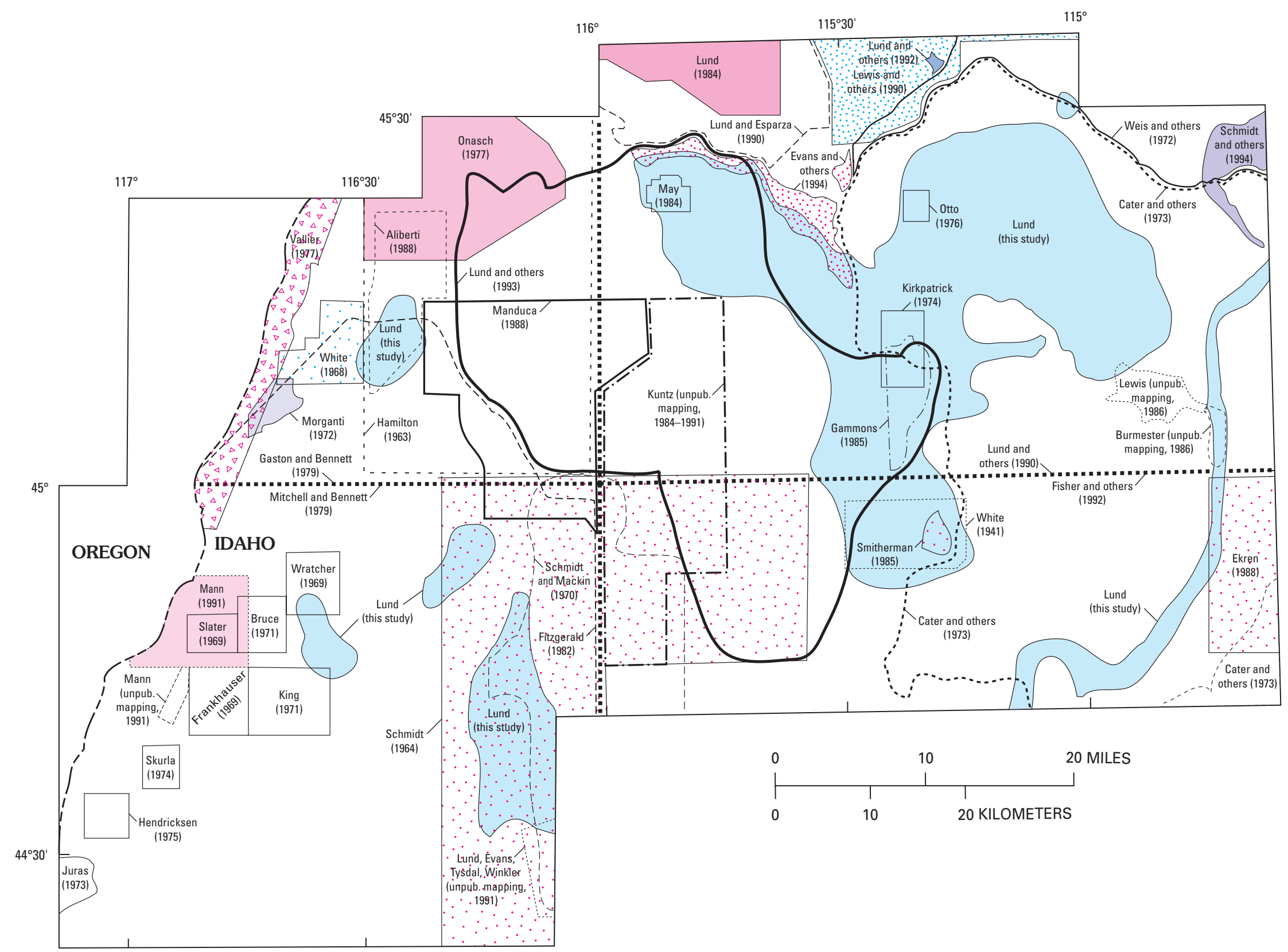

Figure A2. Sources of geologic mapping used to compile geologic map of Payette National Forest and vicinity, west-central Idaho. 


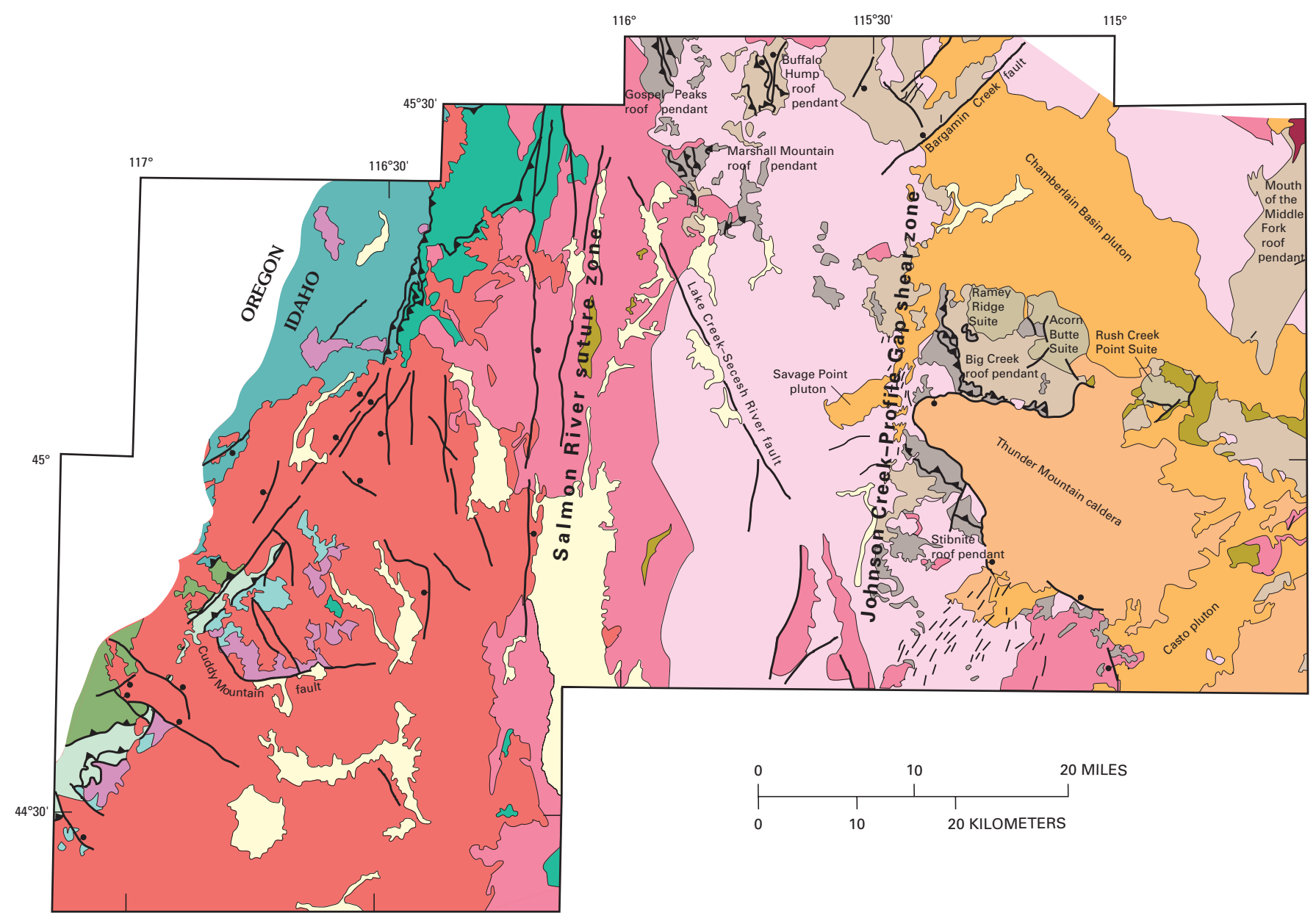

Figure A3. (above and facing page). Generalized geologic map of Payette National Forest and vicinity, west-central Idaho.

A northwest-trending band of Mesoproterozoic metasedimentary rocks is preserved in the Marshall Mountain, Stibnite, Big Creek, and mouth of the Middle Fork roof pendants (fig. A3) as well as near Burgdorf Summit and Sheepeater Mountain (north-central pl. 2), and north of the Salmon River in the Buffalo Hump and Gospel Peaks roof pendants in the Nez Perce National Forest (northern fig. A3). Although some of the Mesoproterozoic rocks are in isolated locations and are metamorphosed to high grades, most of the Mesoproterozoic rocks can be subdivided into two discrete packages of rocks that can be traced into equivalent rocks of lower metamorphic grade in east-central Idaho based on composition, thickness of units, contiguous exposures, and (or) sedimentary structures. Additionally, the studies of the Payette and Salmon National Forests (this study and Evans and Green, 2003, respectively; fig. A1) document that metamorphic-deformational belts parallel the trend of the stratigraphic packages across central Idaho.

\section{Stratigraphic Packages}

The Mesoproterozoic Yellowjacket Formation-Hoodoo Quartzite-argillaceous quartzite succession (Yy, Yh, Yaq, respectively) extends into the eastern side of the forest from the reference areas in the Salmon National Forest about $20 \mathrm{~km}$ east of plate 2 (Ross, 1934; Ekren, 1988; Tysdal, 2000; Tysdal and others, 2000) and can be physically traced to lower Big Creek (east-central pl. 2). Although the metamorphic grade increases from the east into the area of plate 2 and few sedimentary structures remain, the scale of lamination and the overall stratigraphic succession indicate probable correlation of units into lower Big Creek. In the Salmon National Forest, the Yellowjacket and associated units are bounded on the east and north by a basal thrust fault that puts this succession over strata of the Lemhi Group (Tysdal, 2000; Tysdal and others, 2000; K. Lund, unpub. data, 2001-2002; Tysdal and others, 2003). The same or a similar structure probably bounds the northern margin of the Yellowjacket Formation and associated units in the Payette National Forest, enveloped within the elongate body of the Chamberlain Basin pluton (eastern fig. A3). North of this engulfed thrust fault, remnants of footwall rock are marked by greater deformation and different composition, as compared to the Yellowjacket Formation and associated units of the hanging wall. The top of the succession associated with the Yellowjacket Formation is eroded or cut by intrusive rocks both in the reference area in the Salmon National Forest to the east and in this study area; thus, the temporal relationship between this succession and other Mesoproterozoic strata (see subsequent discussion of the Lemhi Group) is unknown. 


\section{EXPLANATION}

Alluvium and glacial deposits (Quaternary)

WEISER EMBAYMENT

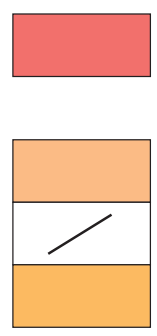

Basalt flows and interbedded sedimentary rocks (Tertiary)

EOCENE MAGMATIC COMPLEX

Challis Volcanic Group (Eocene)

Rhyolite to dacite dikes (Eocene)

Hypabyssal intrusive rocks (Eocene)

IDAHO BATHOLITH

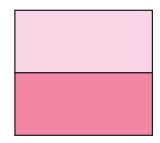

Granite and granodiorite (Late Cretaceous)

Foliated granodiorite and tonalite (Late Cretaceous)

ALLOCHTHONOUS BLUE MOUNTAINS ISLAND ARC

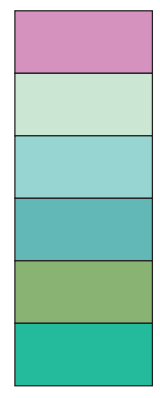

Granodiorite, quartzdiorite, and gabbro (Cretaceous to Jurassic)

Intra-arc basin rocks of Izee terrane (Jurassic)

Island-arc rocks of Olds Ferry terrane (Triassic)

Island-arc rocks of Wallowa terrane (Triassic to Permian)

Fore-arc basin rocks of Baker terrane (Mesozoic to Paleozoic)

Metamorphosed island-arc rocks (Jurassic to Permian)

\section{LAURENTIAN ROCKS}

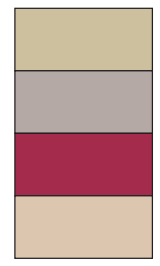

Syenite-diorite plutons (Neoproterozoic)

Windermere Supergroup (Neoproterozoic to lower Paleozoic(?))

Granite and augen gneiss (Mesoproterozoic)

Lemhi Group and Swauger Formation; Yellowjacket Formation and Hoodoo Quartzite (Mesoproterozoic)

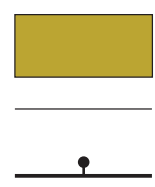

Metamorphosed rocks, undivided (Neoproterozoic to Mesoproterozoic)

Contact

Normal fault-Bar and ball on downthrown side where relative movement known

Thrust fault-Sawteeth on upper plate

Metasedimentary rocks in the Big Creek roof pendant along the middle part of the Big Creek drainage (east-central fig. A3 and center pl. 2) are not in physical contact with other Mesoproterozoic rocks. These rocks are herein correlated with part of the Mesoproterozoic Lemhi Group based on preserved sedimentary structures and stratigraphic succession. Specific correlations are with the upper Apple Creek and Gunsight Formations of the upper Lemhi Group and with the overlying Swauger Formation (Ylau, Ylg, and Ys, respectively) (Ruppel, 1975). The prominent centimeter-scale sandstone-siltite (light-and-dark) layering and water-escape features in the biotite phyllite (fig. B19) are identical to sedimentary features found in rocks described as the banded siltite unit of the Apple Creek Formation in the Blackbird mine and northern Lemhi Range areas east of the forest (Tysdal and others, 2000; Tysdal and others, 2003; previously called the middle part of the Yellowjacket Formation in the Blackbird mine area by Connor and Evans, 1986; Evans, 1998). Quartz-feldspar-rich phyllite interlayers in metasandstone form a unit most likely correlative with the arkosic sandstone of the Gunsight Formation east of the forest (Tysdal and others, 2000; Tysdal and others, 2003; previously thought to be the upper part of the Yellowjacket Formation in the Blackbird mine area by Connor and Evans; 1986; Evans, 1998; and previous workers). An upper quartz-rich metasandstone to quartzite is 
herein correlated with the Swauger Formation (Ys); however, in places, especially Profile and middle Big Creeks, parts of the Swauger Formation are probably included in rocks mapped as the Gunsight Formation. The stratigraphic relationship between these units and the Yellowjacket Formation and associated units (Yy, Yh, Yaq) is unknown regionally but could lie in the little known middle part of the Big Creek drainage in the northern part of the Thunder Mountain caldera. The top of the Lemhi Group in the east-central part of the forest is eroded and Neoproterozoic strata overlie what may have been an angular unconformity.

High-grade migmatitic metasedimentary rocks (Ygn) cut by Mesoproterozoic granite (Yagn) in the mouth of the Middle Fork roof pendant (northeast corner fig. A3 and pl. 2) were previously mapped as lithodemic units (Lund, Evans, and Esparza, 1983; Schmidt and others, 1994). Recent mapping and interpretation of previous work indicate continuity with lower grade metasedimentary rocks to the south and southeast (K. Lund, unpub. data, 2001) and correlation with the Apple Creek Formation of the Lemhi Group (Ylau; Tysdal and others, 2003). Very few primary sedimentary features are preserved in these intensely deformed and metamorphosed rocks, and only structural continuity and stratigraphic succession can be used to suggest correlations among individual units on the extreme east side of the forest and contiguous parts of the Salmon National Forest (K. Lund, unpub. data, 2001-2002). These rocks are part of a northwest-trending belt of high-grade metamorphic rock that, in some areas, was near the point of melting during formation of the Mesoproterozoic plutons (figs. B8 and B9). This suggests that at least some of the metamorphic fabric in these rocks formed in the Mesoproterozoic, which is confirmed by dating studies about $20 \mathrm{~km}$ east of the forest (Doughty and Chamberlain, 1996). By inference, a metamorphic belt trending northwest across central Idaho, including these rocks in the northeastern part of the forest, may be a Mesoproterozoic orogenic belt (K. Lund, unpub. data, 2001-2003).

The high-grade Mesoproterozoic metasedimentary rocks in the Stibnite and Marshall Mountain roof pendants (Ybfq) were not correlated with other Mesoproterozoic packages because the rocks have such a high metamorphic grade and because the exposures are not extensive enough to provide a good sense of stratigraphic sequence. However, compositions, interlayered characteristics, and regional unit trends suggest that these may be high-grade equivalents to the Gunsight Formation (Ylg). Mesoproterozoic exposures east of the Buffalo Hump roof pendant and between the Big Creek and Marshall Mountain roof pendants are also not correlated with other Mesoproterozoic successions primarily because they were not extensively examined during this study. Regional trends interpreted from this study and from mapping in the Salmon National Forest to the east (K. Lund, unpub. data, 2001) suggest that some of these strata may correlate with parts of the Lemhi Group.

\section{Associated Mineral Deposits}

Previously mined gold-silver-copper quartz-vein deposits and other mineralized but unmined areas along the middle reaches of Big Creek in the east-central part of the forest (Cater and others, 1973) are hosted in rocks herein tentatively correlated with the upper part of the Mesoproterozoic Apple Creek Formation (Ylau). Stream-sediment geochemistry indicates a high regional association for cobalt and related elements (Lund and others, 1990). The limited available information suggests that these vein deposits may be younger remobilizations of Blackbird-type cobalt-copper sediment-hosted deposits or zones of high metal concentrations in host rocks that did not originally result in mineral deposits. These indications of cobalt-copper mineralization in the host rocks reinforce correlation of the host rocks with the redefined upper part of the Apple Creek Formation (banded siltite unit) of the Blackbird mining district (Tysdal, 2000; Tysdal and others, 2000).

\section{Metaplutonic Rocks}

Mesoproterozoic porphyritic granite and granitic augen gneiss (Yagn) intruded Mesoproterozoic metasedimentary rocks (Ygn) in and near the lower canyon of the Middle Fork of the Salmon River (Evans, 1981; Lund, Evans, and Esparza, 1983; Lewis and others, 1990; Schmidt and others, 1994). These intrusions are part of a band of similar granites that trends northwest across central Idaho (fig. A3 and pl. 2). Strong deformation fabrics led earliest workers to suggest that these were Archean basement (for example, Umpleby, 1913). Alternatively, before the complexity of intrusive events in Idaho was appreciated, these granites were considered by some workers to be part of the Late Cretaceous Idaho batholith (Ross, 1925; Anderson, 1942; Shockey, 1957). Preliminary $\mathrm{Rb}-\mathrm{Sr}$ model ages for the augen gneiss were about 1,500 Ma and reinforced the idea that the granites and the rocks they intruded might be part of a pre-Mesoproterozoic basement terrane that was then named the Salmon River arch (Armstrong, 1975).

Several samples of these granites in the Salmon National Forest (about $25 \mathrm{~km}$ east of the Payette National Forest) are dated at about 1,370 Ma (Evans, 1981; Evans, 1986; Evans and Zartman, 1990; Doughty and Chamberlain, 1996). The 1,370-Ma age of the granites, together with recent dating of Mesoproterozoic rocks of the Belt Supergroup in western Montana (Evans and others, 2000), indicates that the granites were emplaced near the end of Mesoproterozoic sedimentation. Because of these ages and because the granites postdate Mesoproterozoic basin formation, these Mesoproterozoic granites do not provide evidence for a pre-Mesoproterozoic metamorphic-plutonic terrain called the Salmon River arch (Evans, 1981; Evans and Lund, 1981; Evans and Zartman, 1990; Doughty and Chamberlain, 1996); this concept should be abandoned. 


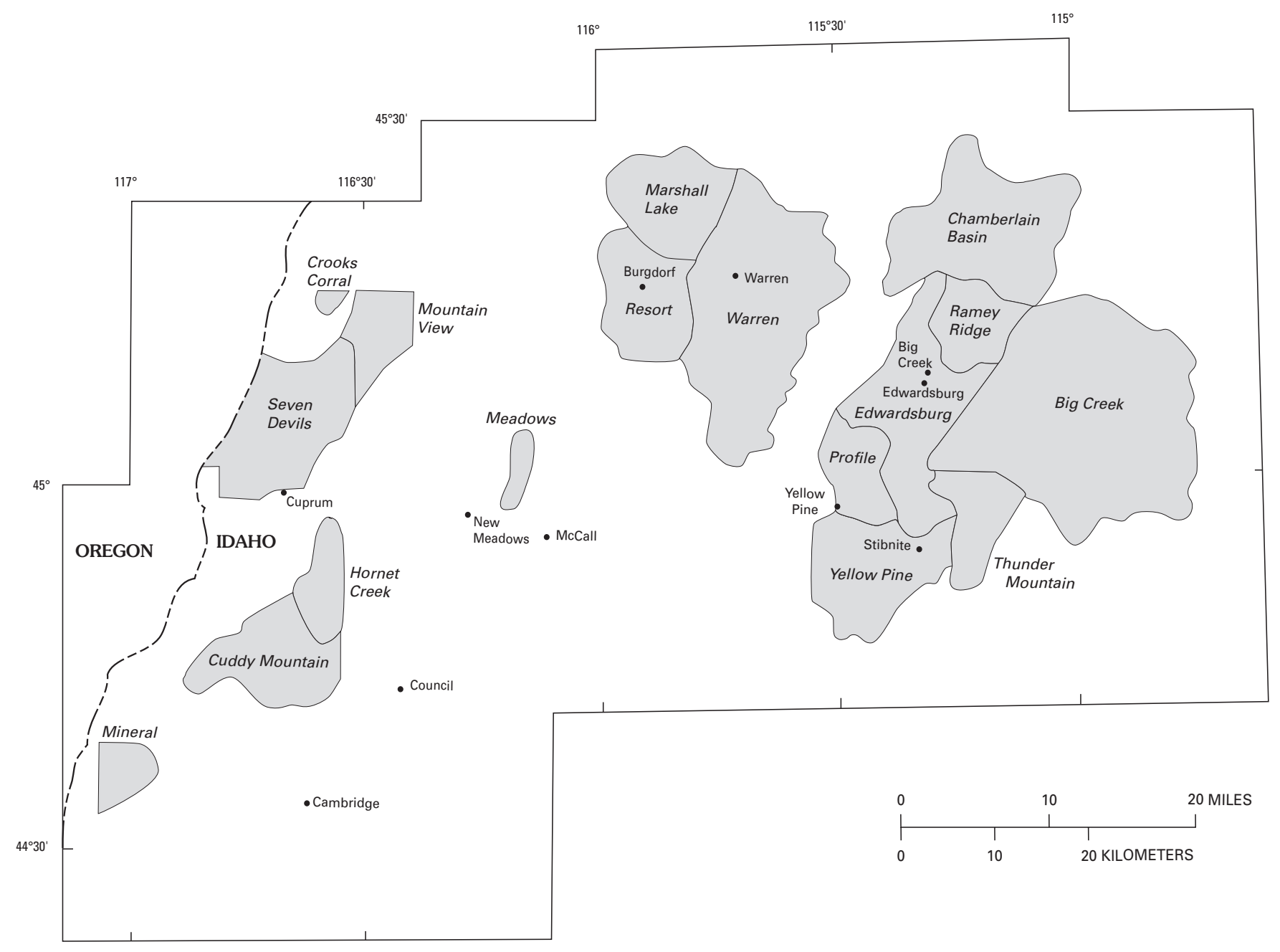

Figure A4. Mining districts in Payette National Forest and vicinity, west-central Idaho.

The chemistry of the granites suggests that they are similar to Mesoproterozoic granites present in a belt from the southwestern United States to Labrador, Canada, and thought to be anorogenic (Evans, 1981; Lewis and others, 1996), caused by melting related to influx of heat by injection of mafic dikes into the sedimentary basin (Doughty and Chamberlain, 1996; Lewis and others, 1996). However, the Mesoproterozoic metasedimentary rocks in the Middle Fork of the Salmon River consist of partial-melt migmatites and, although the leucosomes (melt fractions) were previously thought to be related to formation of the Late Cretaceous Idaho batholith (Hamilton, 1978), they were subsequently dated at about 1,370 Ma (Doughty and Chamberlain, 1996). In the same area, Mesoproterozoic pophyritic granite/augen gneiss (Yagn) occurs both as discrete plutons cutting low- to high-grade metasedimentary rocks and as migmatite stringers and veins in high-grade metasedimentary rocks (figs. B8 and B9). Thus, the granitic magma that formed the porphyritic granite/augen gneiss in the Middle Fork of the Salmon River area may be the result of near in-situ melting during a Mesoproterozoic (about 1,370 Ma) dynamothermal orogenic event rather than a rift-related or anorogenic event.
Amphibolite dikes (ZYam) in the forest cut Mesoproterozoic and oldest Neoproterozoic metasedimentary rocks. The mafic dikes have not been dated but some may be part of the Mesoproterozoic magmatic event that includes amphibolites elsewhere to the east and west (Evans, 1986; Evans and Fischer, 1986; Doughty and Chamberlain, 1996). It has been previously suggested that mafic igneous rocks such as the amphibolite gneiss bodies and dikes (ZYam) in the forest and near Shoup (about $25 \mathrm{mi}$ east of the forest) may have formed from rift-related mafic magma that was injected into the crust and caused crustal melting, in turn forming the Mesoproterozoic granitic magmas (Doughty and Chamberlain, 1996; Lewis and others, 1996). Because mafic dikes in the forest have not been dated and because some intruded rocks are probably Neoproterozoic, some of the dikes may be related to the Neoproterozoic syenite-diorite plutonic bodies that also intruded Mesoproterozoic metasedimentary rocks, indicating that there may be two ages of amphibolite dikes. The available information also allows that amphibolite dikes in the forest are all Neoproterozoic. 


\section{Neoproterozoic Rocks}

A discontinuous northwest-trending band of metamorphosed Neoproterozoic (Windermere Supergroup) and associated Cambrian(?) strata crosses the eastern part of the forest west and south of Mesoproterozoic strata (fig. A3). Parts of this complicated package of rocks are preserved in the Gospel Peaks, Marshall Mountain, Big Creek, and Stibnite roof pendants (pl. 2 and fig. A3) and in the Indian Creek to Little Loon Creek and Grouse Creek areas along the Middle Fork of the Salmon River (southeast corner of pl. 2 and fig. A3).

Rich mineral deposits in and near the Stibnite roof pendant (fig. A3) have been the subject of the few previous studies in that area. Several of these studies resulted in local subdivision of the rocks into lithodemic units that are similar to those used in the present study; additionally, previous workers suggested that some of the rocks might be Paleozoic rather than Mesoproterozoic (Schrader and Ross, 1926; Shenon and Ross, 1936; White, 1941; Ross and Forrester, 1947; Smitherman, 1985). Those age interpretations and lithodemic subdivisions were disputed (Ross, 1962) and the most recent geologic map of Idaho shows all previously recognized metamorphic rocks in the central part of the forest as Mesoproterozoic metasedimentary rocks (Bond, 1978). Additionally, the most recent mapping and compilation of the southeastern part of the forest (southern one-third of pl. 2, Challis $1^{\circ} \times 2^{\circ}$ quadrangle) show all previously known metamorphic rocks in the Stibnite area as either the Mesoproterozoic Yellowjacket Formation or Hoodoo Quartzite (Fisher and others, 1992), terminology defined for Mesoproterozoic rocks east of the forest (Ross, 1934; Ekren, 1988; Tysdal, 2000; Tysdal and others, 2000).

Although no metamorphic rocks are shown on the State map of Idaho in the area of Marshall Mountain (Bond, 1978), more recent reconnaissance mapping of the Marshall Lake mining district (May, 1984) described metamorphic strata in a large roof pendant there and adopted an age of Paleozoic (fig. A4) as proposed by White (1941) for metamorphic rocks near Stibnite.

Metamorphic rocks in the southern part of the Big Creek roof pendant (Profile Gap mining district; figs. A3 and A4) were partly mapped during study of mineral deposits by Shenon and Ross (1936). In that study, rocks at Profile Gap were suggested to be Paleozoic, whereas similar rocks near the settlement of Big Creek just a few kilometers to the north were shown as Mesoproterozoic Yellowjacket Formation and Hoodoo Quartzite (Shenon and Ross, 1936). During a later study of the metamorphic rocks near the settlement of Big Creek, a metavolcanic layer was recognized in the metamorphic rocks; however, the whole package was correlated with the Mesoproterozoic Yellowjacket Formation (Leonard, 1962). Subsequently, a more complete description of the lithologic sequence of the rocks near Big Creek was made but correlation with Mesoproterozoic strata was not questioned (Kirkpatrick, 1974).

In the southeastern part of the forest, mapping of the Challis $1^{\circ} \times 2^{\circ}$ quadrangle identified relatively small areas of metamorphic inclusions in plutonic rock. The metamorphic rocks were described as roof pendants, were mostly not differentiated compositionally, and were suggested to be Mesoproterozoic in age (Fisher and others, 1992).

Strata in the Gospel Peaks roof pendant were previously suggested to be Neoproterozoic (Lund, 1984, 1988b; Lund and Snee, 1988) and strata in the Big Creek roof pendant were recognized as part of the same succession (Lund and others, 1997). However, the isolation of the central Idaho exposures from sections with published descriptions and the lack of temporal context made it difficult to develop specific correlations for the central Idaho strata. The discovery of zircon-bearing felsic volcanic strata in roof pendants in the forest provided the opportunity for directly dating this largely metasedimentary succession, thereby putting them in a regional context. The new isotopic dates and regional correlations derived from work in the forest (Lund and others, 2003) also provide a better temporal framework for other Cordilleran Neoproterozoic strata that are much better known but remain largely undated.

\section{Windermere Supergroup}

The name "Windermere Group" is recognized by the U.S. Geological Survey for rocks of the Neoproterozoic facies belt in the United States part of the Cordillera, whereas "Windermere Supergroup" is preferred for the more completely preserved succession in the Canadian part of the Cordillera. Because Windermere Supergroup is more widely used for the better preserved exposures, this report follows the recent Decade of North American Geology usage (Link and others, 1993) and the term "Windermere Supergroup" will be used for Neoproterozoic strata in the forest. However, the formal group-rank units of the Windermere Supergroup will not be used in this report. A recent trend in the literature includes both older and younger Neoproterozoic rift-related units within the Windermere Supergroup (see Lund and others, 2003) and this usage is followed.

Rocks of the Windermere Supergroup in central Idaho are herein divided into four packages that are informally designated as Gospel Peaks succession A through D. The most complete stratigraphic sections are in the Gospel Peaks (north-central edge fig. A3; northwestern corner pl. 2), for which the succession is named. Herein, nine new formations (fig. A5) are named and described for metamorphosed carbonate-siliciclastic-volcanic-diamictite strata that overlie Mesoproterozoic rocks in roof pendants across central Idaho. The newly described stratigraphic section is composite, based on isolated exposures of parts of the succession. The areas for which each formation is named and where each is best exposed are shown in figure A6. Most are named for exposures in the Gospel Peaks roof pendant where most of the units are best exposed. Units not exposed there are named for exposures in the Big Creek and Stibnite roof pendants. 


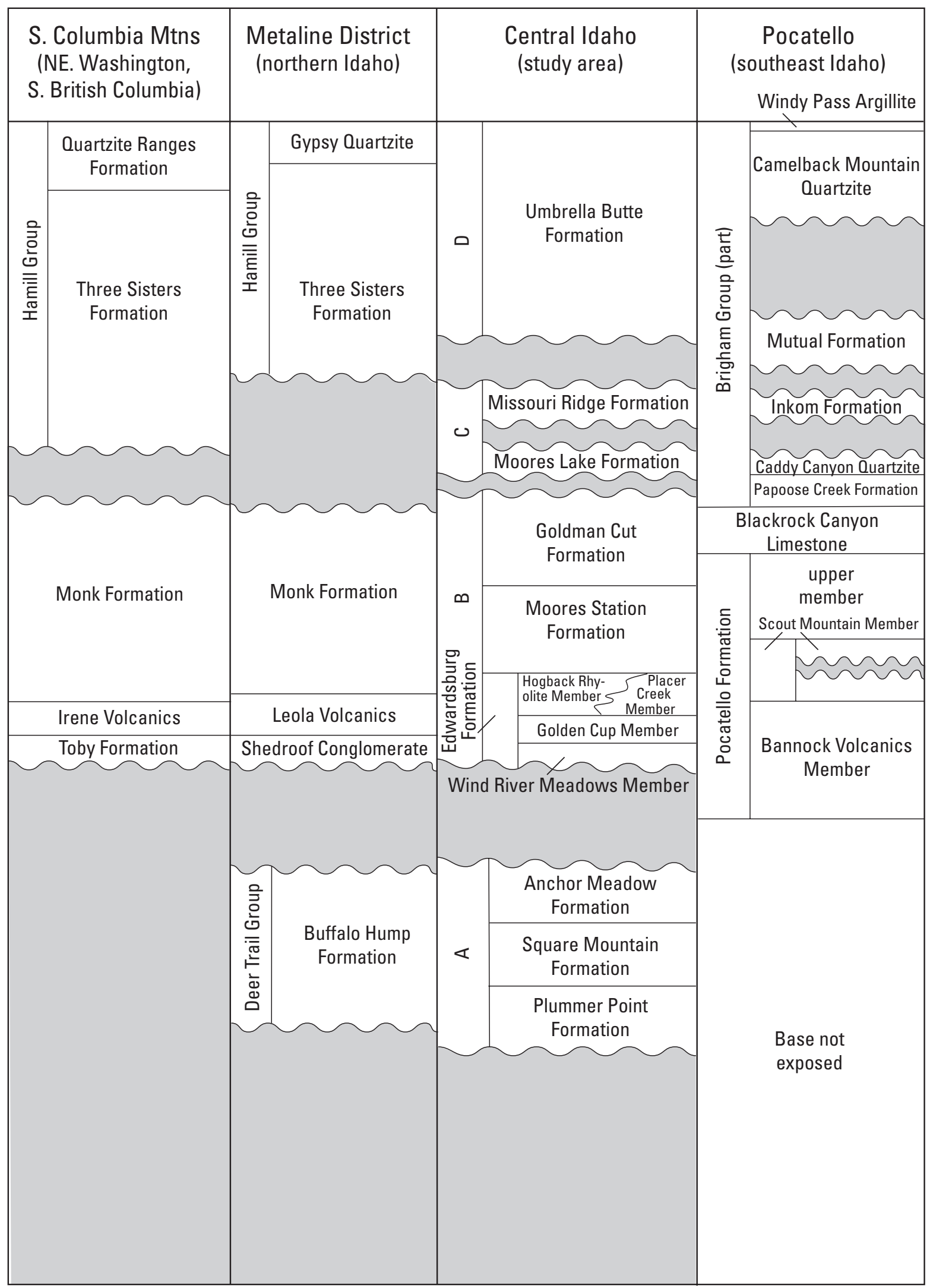

Figure A5. Regional correlation diagram for Neoproterozoic strata of northern Rocky Mountains showing new nomenclature for Gospel Peaks successions A-D of Windermere Supergroup in central Idaho. 


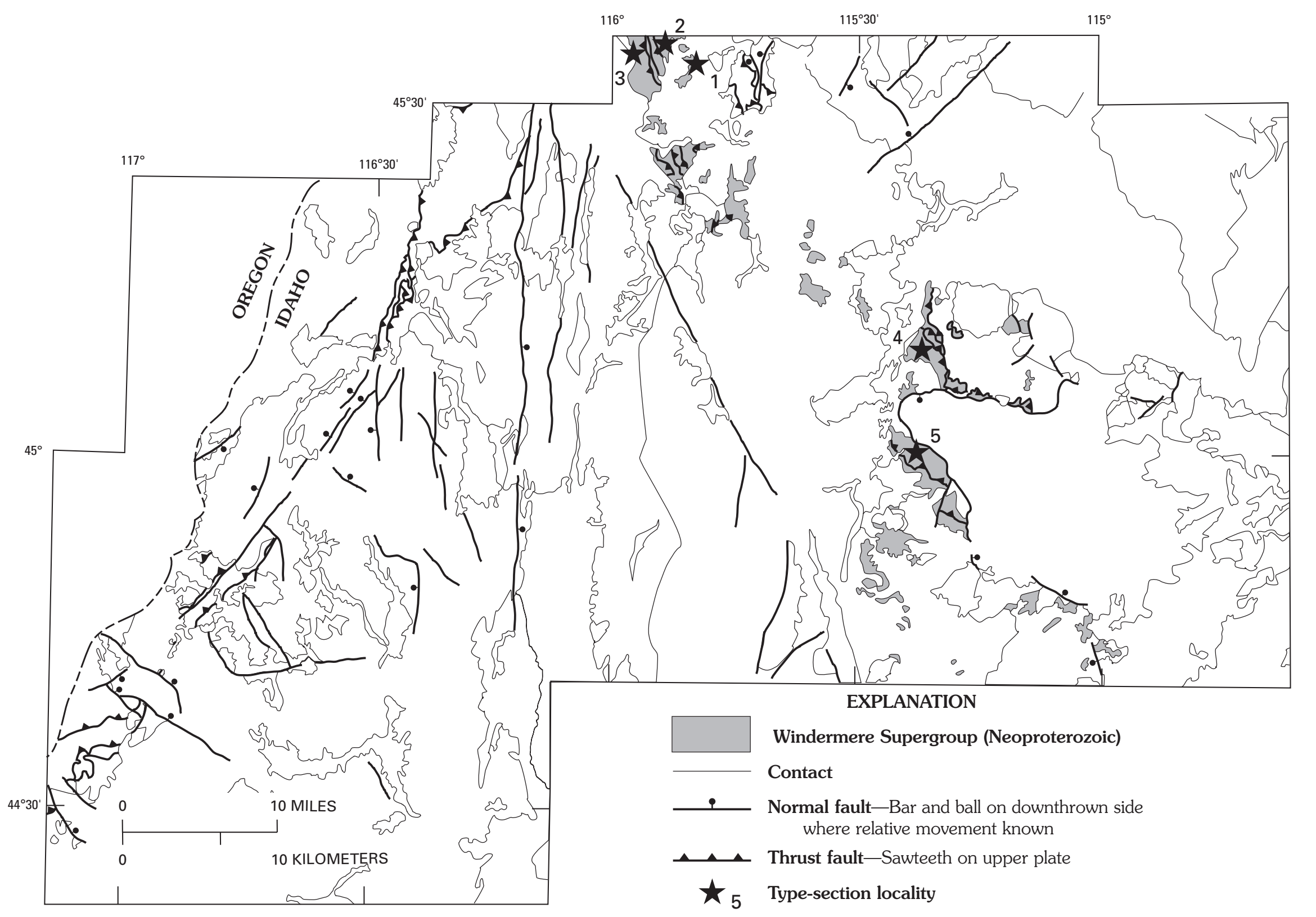

Figure A6. Locations of type sections for Neoproterozoic units named and described in this study. 1, Plummer Point Formation; 2, Square Mountain, Anchor Meadow, Moores Station, and Moores Lake Formations and Wind River Meadows Member of Edwardsburg Formation; 3, Umbrella Butte Formation; 4, Edwardsburg Formation (including Hogback Rhyolite, Placer Creek, and Golden Cup Members) and Goldman Cut Formation; 5, Missouri Ridge Formation. 
Table Al. Geochemical data for volcanic rocks of Neoproterozoic Edwardsburg Formation.

IWavelength dispersive X-ray nuorescence (WDXRF) analyses perrorrned by U.S. Geological Survey laboratories, Denver, Colo.J

\begin{tabular}{|c|c|c|c|c|c|c|c|c|c|c|c|c|}
\hline $\begin{array}{l}\text { Field } \\
\text { number }\end{array}$ & Sample description & $\mathrm{SiO}_{2}$ & $\mathrm{Al}_{2} \mathrm{O}_{3}$ & $\mathrm{FeTO}_{3}{ }^{1}$ & $\mathrm{MgO}$ & $\mathrm{CaO}$ & $\mathrm{Na}_{2} \mathrm{O}$ & Ко & $\mathrm{TiO}_{2}$ & $\mathbf{P}_{2} \mathbf{O}_{5}$ & $\mathrm{MnO}$ & $\mathrm{LOI}^{2}$ \\
\hline 3KL045 & $\begin{array}{l}\text { Amphibolite, Golden Cup } \\
\text { Member. }\end{array}$ & 46.7 & 8.87 & 11.5 & 13.3 & 12.4 & 1.26 & 0.53 & 2.50 & 0.32 & 0.18 & 0.62 \\
\hline 99KL027 & $\begin{array}{l}\text { Amphibolite, Golden Cup } \\
\text { Member. }\end{array}$ & 42.6 & 8.70 & 11.5 & 10.6 & 15.5 & 1.94 & 0.19 & 2.26 & 0.39 & 0.21 & 4.92 \\
\hline 2KE084A & $\begin{array}{l}\text { Rhyolite, Hogback Rhyolite } \\
\text { Member. }\end{array}$ & 62.2 & 15.4 & 7.13 & 0.81 & 2.07 & 5.07 & 2.99 & 0.68 & 0.16 & 0.22 & 1.14 \\
\hline 98KL021 & $\begin{array}{l}\text { Rhyodacite, Wind River } \\
\text { Meadows Member. }\end{array}$ & 65.7 & 13.9 & 6.73 & 2.11 & 1.78 & 4.07 & 2.75 & 1.39 & 0.72 & 0.13 & 0.61 \\
\hline 00KL040 & $\begin{array}{l}\text { Rhyodacite, Wind River } \\
\text { Meadows Member. }\end{array}$ & 68.2 & 13.1 & 6.70 & 1.38 & 1.03 & 4.6 & 1.96 & 1.11 & 0.42 & 0.10 & 0.66 \\
\hline
\end{tabular}

${ }^{1} \mathrm{FeTO}_{3}$, total iron as $\mathrm{Fe}_{2} \mathrm{O}_{3}$.

${ }^{2} \mathrm{LOI}$, loss on ignition.

\section{Gospel Peaks Succession A}

Three newly named formations overlie the Mesoproterozoic units and underlie dated Neoproterozoic units (see the following section). These formations are relatively thin in comparison to the great thickness and continuity of compositions that are characteristic of Mesoproterozoic units. The lowest formation, the Plummer Point Formation (Zpp), is named for exposures at Plummer Point at the eastern edge of the Gospel Peaks roof pendant (location 1 in fig. A6; northwestern pl. 2; Marble Butte 7-1/2 ' quadrangle). The Plummer Point Formation is predominantly sillimanite-muscovite schist and amphibolite and minor calc-silicate gneiss. The Plummer Point Formation is gradational with the overlying Square Mountain Formation over about $1 \mathrm{~m}$ on the east side of Square Mountain (location 2, fig. A6; Marble Butte 7-1/2` quadrangle). It discordantly overlies Mesoproterozoic units. The basal contact is structural in some places and possibly unconformable in others. The Square Mountain Formation (Zsm), which forms the middle unit, is named for exposures that underlie Square Mountain in the Gospel Peaks roof pendant (location 2, fig. A6; Marble Butte 7-1/2‘ quadrangle). This formation is also well exposed in the core of the Knob Lakes syncline (Lund, 1984) in the center of the Gospel Peaks roof pendant (north of northeastern corner of pl. 2). The Square Mountain Formation consists of massive and crossbedded quartzite; bimodal-size quartz grains include minor quartz granules and pebbles. The Anchor Meadow Formation (Zam) is named for Anchor Meadow on the southeast side of the Gospel Peaks roof pendant and is best exposed on the ridge north of Anchor Creek and west of Square Mountain (location 2, fig. A6; Marble Butte 7-1/2' quadrangle). The Anchor Meadow Formation, at the top of Gospel Peaks succession A, is calc-silicate gneiss having prominent centimeter-scale layering. The lower part of the Anchor Meadow Formation is predominantly dark, well-layered, calc-silicate-bearing siliciclastic rock; the upper part is light-gray-green, tremolite-bearing marble.

Bedding orientations, types of structures, and metamorphic history in the Neoproterozoic rocks differ significantly from those of the underlying older units. A marked regional change in structural style, metamorphic grade, and bedding attitudes between Mesoproterozoic rocks and overlying rocks suggests the base of the Neoproterozoic rocks may have been unconformable. Alternatively, the base of the Plummer Point Formation is commonly strongly deformed, suggesting that in some areas the unit marks a structural discontinuity between units above and below, or that older gneisses are included at the base of the unit along structures. Where overlain by the younger Neoproterozoic units and not disrupted by structures, the Square Mountain and Anchor Meadow Formations are variably missing but the Plummer Point Formation is usually present. This incomplete stratigraphic record suggests differential erosion and an unconformity at the top of these strata.

The location of these units between Mesoproterozoic and dated Neoproterozoic strata on a regional basis and their composition and thickness characteristics suggest possible general correlations (fig. A5). These strata may be equivalent to units such as the Buffalo Hump Formation, which lies at the top of the Deer Trail Group of northern Idaho and northeastern Washington (Campbell and Loofbourow, 1962; Evans, 1987; Miller and Whipple, 1989), or the Big Cottonwood Formation or Uinta Mountain Group of northern Utah (Ehlers and others, 1997), which may be the base of the Neoproterozoic section and related to onset of Neoproterozoic rifting (Evans, 1987; Ehlers and others, 1997). 


\section{Gospel Peaks Succession B}

Gospel Peaks succession B includes two lithologic packages, in ascending order: (1) diamictite and bimodal volcanic strata and (2) carbonate and siliciclastic strata. The bimodal volcanic and diamictite strata constitute the herein named Edwardsburg Formation (Ze), which is divided into four interfingered members: the Wind River Meadows, Golden Cup, Placer Creek, and Hogback Rhyolite Members. The most complete sections of the Edwardsburg Formation and its four members are found in fault-disrupted, overturned exposures on ridges near the settlements of Big Creek and Edwardsburg (location 4 of fig. A6; center pl. 2). Carbonate and fine-grained siliciclastic strata overlie this lithologic package and are herein named the Moores Station and Goldman Cut Formations. Based on the rocks present in the forest and on proposed regional correlations (Lund and others, 2003), rocks of the Gospel Peaks succession $\mathrm{B}$ represent continental rifting with consanguineous glaciation and a subsequent interglacial period.

The Wind River Meadows Member is herein named for Wind River Meadows in the southern Gospel Peaks roof pendant (location 2, fig. A6; Hanover Mountain 7-1/2‘ quadrangle). The matrix-supported diamictite of the Wind River Meadows Member is the most continuous and distinctive unit in the central Idaho Neoproterozoic strata. Clasts of quartzite and calc-silicate gneiss composition in this matrix-supported diamictite probably originated from the underlying Gospel Peaks succession A. This origin suggests that faulting in the basin exposed subjacent units to erosion, resulting in their redeposition as clasts in this younger unit. Link and others (1994) interpreted deposits such as these to have formed in an ice-proximal basin environment lacking currents to rework the deposits.

Local rhyodacite flow breccia, tuff, graded volcaniclastic sandstone, and heterogeneous volcaniclastic conglomerate dominate the base of the Wind River Meadows Member and may intertongue with, or regionally grade into, the matrix-supported diamictite. Rhyodacite tuff is dated by U-Pb SHRIMP dating at $687 \pm 10 \mathrm{Ma}$ (Lund and others, 2003), giving a maximum age for the volcanic-glaciogenic strata. Primary sedimentary structures, including tuffaceous flow breccia and water-laid tuff with graded bedding, are locally preserved and show that the unit is overturned in the exposure west of Big Creek. Volcanic conglomerate in the upper part of this unit contains a heterogeneous mixture of rhyodacite clasts and minor quartzite clasts in a water-worked tuffaceous matrix. The composition of the clasts indicates that both the local rhyodacite and older quartzite units were being eroded and redeposited into this unit. The volcaniclastic conglomerate and graded sandstone of the Wind River Meadows Member are similar to deposits in the Neoproterozoic Scout Mountain Member of the Pocatello Formation near Pocatello, Idaho, which are interpreted to have formed as ice-distal, subwave-base, gravity-flow deposits (Link and others, 1994). Link and others (1994) further interpreted such heterogeneous diamictite and graded sandstone deposits as having been deposited in deeper water settings than rocks such as the matrix-supported diamictites (previously described). They sug- gested that these deposits may have formed either as transitional glacial-marine sediments in the area of grounded till or as rapid rain-out below icebergs at the zone of glacial disintegration. The laterally gradational relationship between matrix-supported diamictite and rhyodacites of the Wind River Meadows Member suggests synchronous volcanism and glaciation in the basin.

Metamorphosed mafic volcanic and volcaniclastic rocks of the Golden Cup Member form the middle of the Edwardsburg Formation. The Golden Cup Member is herein named for the Golden Cup mine on the south side of the ridge south of Placer Creek (location 4, fig. A6; Big Creek 7-1/2' quadrangle) in the Big Creek roof pendant. Mafic volcaniclastic rocks of this member are well exposed at the head of Moores Creek (location 2, fig. A6; Hanover Mountain 7-1/2 ' quadrangle) in the Gospel Peaks roof pendant. Although not previously recognized as part of the Windermere Supergroup, mafic volcanic rocks interlayered with metasedimentary rocks near Big Creek, Idaho, were described by Leonard (1962), who correlated them and the enclosing metasedimentary rocks with the Mesoproterozoic Yellowjacket Formation, a conclusion not supported by stratigraphy or dating. Geochemical data from mafic volcanic rocks of the Golden Cup Member (table 1) indicate that these rocks originated as tholeiitic basalt; their geochemistry is similar to published geochemical data from the Neoproterozoic Bannock Volcanic Member of the Pocatello Formation, southeastern Idaho (Harper and Link, 1986), and the volcanic member of the Huckleberry Formation, northeastern Washington (Devlin and others, 1985). The data suggest that the Golden Cup Member, the Bannock Volcanic Member of the Pocatello Formation, and the volcanic member of the Huckleberry Formation resulted from continental rifting (Devlin and others, 1985; Harper and Link, 1986; Lund and others, 2003). The presence of local felsic volcanic rocks interlayered with the central Idaho strata suggests proximity to persistent rift-related faults because both the rhyodacite in the Wind River Meadows Member and the younger Hogback Rhyolite Member (see following paragraphs) are local deposits.

The Placer Creek Member of the Edwardsburg Formation is herein named for Placer Creek, $5 \mathrm{~km}$ northwest of Big Creek (location 4, fig. A6; Big Creek 7-1/2` quadrangle), where this member is best exposed on ridges at the head of Placer Creek. This member is also exposed on Cottontail Point $9 \mathrm{~km}$ north of Warren (north-central pl. 2), on ridges near the headwaters of Bear Creek in the northern and eastern Marshall Lake roof pendant (northwestern pl. 2), and on the ridge about $2 \mathrm{~km}$ southeast of Moores Lake in the Gospel Peaks roof pendant (north of northwest corner pl. 2). The Placer Creek Member is composed of two distinct types of clast-supported conglomerate. Clasts in the lower clast-supported conglomerate are a heterogeneous mixture of mafic and felsic volcanic clasts whereas the upper clast-supported conglomerate contains a mixture of quartzite and calc-silicate pebbles together with mafic and rhyodacitic volcanic pebbles. The heterogeneous composition of clasts from this upper clast-supported conglomerate indicates erosion of both the underlying Gospel Peaks succession A and the local volcanic rocks of the Golden Cup Member and possibly the 
Hogback Rhyolite Member. These diamictites are similar to deposits interpreted to have formed by gravity-flow reworking of glacial-marine sediments (Link and others, 1994). The different compositions of the clasts and the nature of this diamictite, as compared with diamictite of the Wind River Meadows Member, indicate that the diamictites resulted from separate glacial advances and different environments of deposition (see, for example, Link and others, 1994).

Locally, the top of the Edwardsburg Formation is the herein named Hogback Rhyolite Member (earlier called the rhyolite of Big Creek in Evans and others, 1997). This unit is named for the hogback (location 4, fig. A6; Big Creek 7-1/2 quadrangle) in the valley at Big Creek (central pl. 2); the only identified exposures of this member are in the valley of Big Creek near the settlements of Big Creek and Edwardsburg. The Hogback Rhyolite Member is composed of epiclastic porphyritic rhyolite tuff, tuff breccia, and tuff. The textures indicate that this is an extrusive flow. The Hogback Rhyolite Member is dated at $687 \pm 7 \mathrm{Ma}$ by U-Pb SHRIMP methods (Lund and others, 2003; preliminary data previously reported in Evans and others, 1997). This date provides an upper limit for the volcanic-glaciomarine rocks of the Edwardsburg Formation.

The regionally extensive Moores Station Formation (Zms) is herein named for exposures of a composite unit that is well exposed near Moores Station in the Gospel Peaks roof pendant (location 2, fig. A6; Hanover Mountain 7-1/2‘ quadrangle). The Moores Station Formation is also well exposed at the head of Placer Creek (location 4, fig. A6) in the Big Creek roof pendant and in fault slivers near Cinnabar Peak (east-central pl. 2) in the Stibnite roof pendant. The formation is composed of interlayered dark apatite-pyrite-bearing fine-grained quartzite, calc-silicate gneiss, marble, muscovite schist, and metasiltite layers. The compositions represent original intertonguing of black shale and carbonate layers and variations of the two. Thin dark apatite-pyrite-bearing silicic layers may have formed as silicate-facies iron-formation such as formed in Windermere (Ross and others, 1989) and other Proterozoic rift environments (Spry and others, 2001). The relative amount of each composition in the interbedded strata varies across the map area.

The Moores Station Formation grades upward into the andalusite-mica schist of the herein named Goldman Cut Formation (Zgc), which is best exposed at Goldman Cut (location 4, fig. A6; Wolf Fang Peak 7-1/2' quadrangle) on the drainage divide between Smith and Government Creeks about $3 \mathrm{~km}$ northwest of Big Creek (central pl. 2). The Goldman Cut Formation is also present in fault slivers near Cinnabar Peak in the Stibnite roof pendant (east-central fig. A3; central pl. 2). The Goldman Cut Formation is omitted in the otherwise more complete stratigraphic section of the Gospel Peaks pendant (northwest corner pl. 2, north-central fig. A3) perhaps because of erosion at the overlying unconformity at the base of the Moores Lake Formation (see following paragraphs). Together, the carbonate and siliciclastic strata of the Moores Station and Goldman Cut Formations are strikingly similar to units having similar compositions and parallel stratigraphic positions above the volcanic-diamictite sections, and correlated the length of the
Cordillera (fig. A5; Lund and others, 2003). The carbonate and siliciclastic units of the Moores Station and Goldman Cut Formations correlate with units in the lower part of the "terrigenous detrital sequence" of Link and others (1993). Rocks correlative with the carbonate and fine-grained siliciclastic rocks of the Moores Station and Goldman Cut Formations are interpreted as post-rift deposits of a continental slope to platform turbidite system (Ross and others, 1995) and as post-glacial deposits in that environment (Link and others, 1994).

\section{Gospel Peaks Succession C}

Gospel Peaks succession C comprises two siliciclastic and carbonate units that overlie the glaciogenic and terrigenous detrital successions of Gospel Peaks succession B. Based on proposed regional correlations (fig. A5), succession $\mathrm{C}$ represents another possible Neoproterozoic glacial and interglacial succession.

The Moores Lake Formation ( $\mathrm{Zml}$ ) is herein named for predominantly quartz metasandstone to quartzite rocks that are best exposed at the head of Moores Lake Creek (location 2, fig. A6; Hanover Mountain 7-1/2 ' quadrangle) in the Gospel Peaks roof pendant (north-central fig. A3; northwest corner pl. 2). The Moores Lake Formation is composed of recrystallized quartz-rich metasandstone to quartzite but includes lenses of quartzite-cobble conglomerate near its base (Lund and others, 2003). Where best exposed in the Gospel Peaks roof pendant (north-central fig. A3, northwestern pl. 2), the presence of the conglomerate lenses and the absence of the elsewhere underlying Goldman Cut Formation suggest a basal unconformity. The quartzite-cobble conglomerate and quartzite of the Moores Lake Formation are similar to, and in the same stratigraphic position as, the Caddy Canyon Quartzite in southeastern Idaho and Utah (fig. A5). Together with an overlying regional unconformity, the Moores Lake Formation is interpreted to document the time of a younger Neoproterozoic glacial episode than that represented by the glaciomarine rocks of the Edwardsburg Formation (Devlin and others, 1985; Link and others, 1993; see discussion in Lund and others, 2003).

The Missouri Ridge Formation ( $\mathrm{Zmr}$ ) is herein named for exposures on Missouri Ridge (location 5, fig. A6; Stibnite 7-1/2' quadrangle) in the northern Stibnite roof pendant (central fig. A3 and pl. 2). The Missouri Ridge Formation is also exposed as fault slivers in the southern Stibnite roof pendant but is absent in the Marshall Lake and Gospel Peaks roof pendants (fig. A3). The Missouri Ridge Formation is a unique ribbon-laminated calcareous and siliciclastic unit that can be traced discontinuously southeastward across the forest into ribbon-laminated, carbonate-bearing siltite and marble of the "carbonate-siltstone sequence" of Hobbs and Hays (1990; Hobbs and others, 1991), suggesting further regional extent. The Missouri Ridge Formation is in a similar stratigraphic position as a number of lithologically similar units along the Cordillera (fig. A5; Lund and others, 2003) that have been interpreted as being deposited on the developing continental slope of the Neoproterozoic rift basin (Ross and others, 1989). 


\section{Gospel Peaks Succession D}

Gospel Peaks succession D comprises the Umbrella Butte Formation (Zub), which is named for exposures at Umbrella Butte in the Gospel Peaks roof pendant (location 3, fig. A6; Hanover Mountain 7-1/2 ' quadrangle). The Umbrella Butte Formation is predominantly quartzite and arkosic quartzite-pebble conglomerate but includes continuous layers of carbonate and schist. Several horizons of quartzite-pebble conglomerate as much as $5 \mathrm{~m}$ thick are found near the base of this unit. Several laterally traceable 5- to 10-m-thick marble and schist units are found higher in the unit (Lund, 1984; Lund and others, 1997; and interpreted from maps by White, 1941; Smitherman, 1985). Where the pebbles are found, it is a distinctive unit. Where nonconglomeratic, the quartzite is difficult to distinguish from the older quartzite units, the Moores Lake, Square Mountain, or Swauger Formations. The Umbrella Butte Formation traces discontinuously along a southeastern trend across central Idaho to the Clayton area (25 km south of southeast corner pl. 2) where Lower Cambrian or Neoproterozoic quartzites in several thrust fault slivers (Hobbs and Hays, 1990; Hobbs and others, 1991) are probably correlative. Quartzite-dominant units in central Idaho above the carbonate and siliciclastic section do not contain paleontologic or geochronologic control. They fit in the general regional pattern of Neoproterozoic carbonate and siliciclastic units giving way upward to thick latest Neoproterozoic to Cambrian quartzite strata along the length of the Cordillera (fig. A5; Lund and others, 2003).

\section{Correlation and Regional Significance}

Dating (Lund and others, 2003) is critical to documenting the Neoproterozoic stratigraphic section recently mapped in central Idaho (Lund, 1984; Lund and others, 1997; this study). The dates also give a stratigraphic context to rocks that are younger than Mesoproterozoic but older than the dated rocks. The ages determined for volcanic rocks in the Edwardsburg Formation (Ze) indicate that these rocks are part of the Windermere Supergroup and can be fit into a regional stratigraphic framework (fig. A5; Link and others, 1993; Lund and others, 2003). The matrix-supported diamictite of the Wind River Meadows Member below the mafic volcanic rocks of the Golden Cup Member is correlative with the Toby Formation and Shedroof Conglomerate (locally called the conglomerate member of the Huckleberry Formation) in Canada to northeastern Washington and northern Idaho (fig. A5). The mafic volcanic rocks of the Golden Cup Member are correlative with the Irene and Leola Volcanics (locally called the volcanic member of the Huckleberry Formation) in Canada to northeastern Washington and northern Idaho (Devlin and others, 1985) and partly correlative with the Bannock Volcanic Member of the Pocatello Formation in southeastern Idaho (Harper and Link, 1986; Link and others, 1993). The upper clast-supported diamictite of the Placer Creek Member is equivalent to the lower part of the Monk Formation from Canada to northeastern Washington and northern Idaho and to the Scout Mountain Member of the Pocatello Formation in southeastern Idaho (fig. A5). The overlying interlayered carbonate and siliciclastic Moores Station and Goldman Cut Formations are correlative with the Horsethief Creek Group and Monk Formation in Canada to northeastern Washington and northern Idaho and the upper member of the Pocatello Formation in southeastern Idaho (fig. A5; Link and others, 1993; Lund and others, 2003).

Recognition of two separate stratigraphic packages in the roof pendants in central Idaho and dating of the Neoproterozoic metavolcanic rocks at the settlement of Big Creek as Neoproterozoic (Lund and others, 2003) change the understanding of the geologic setting and history of the region. It can now be interpreted that the Neoproterozoic rocks were deposited on the rifted western Laurentian margin and continental shelf/ slope. Although a central Idaho segment of the continental miogeocline was long thought to be missing (Stewart, 1991), this study shows that it is possible to trace the miogeoclinal rocks more continuously than previously thought through Canada and northeastern Washington, across central Idaho in this study, and into southeastern Idaho, Utah, Nevada, and California (Lund and others, 2003).

\section{Metaplutonic Rocks}

Neoproterozoic syenite-diorite suites (Zsd) are exposed as three bodies along a northwest trend (Cater and others, 1973); these are, from west to east, the Ramey Ridge, Acorn Butte, and Rush Creek Point suites (fig. A3). Syenite and diorite are intermingled on outcrop scale and herein interpreted as co-existing magmas although the diorite component of the Ramey Ridge suite was first thought to be metavolcanic inclusions in syenite (thus, Ramey Ridge "Complex" of Leonard, 1963). The Ramey Ridge suite intruded Mesoproterozoic strata tentatively correlated with the upper Apple Creek Formation (Ylau). The Acorn Butte and Rush Creek Point suites intruded Mesoproterozoic Yellowjacket Formation biotite phyllite (Yy) and probable Mesoproterozoic Hoodoo Quartzite (Yh) and the overlying argillaceous quartzite unit (Yaq) in the eastern Big Creek roof pendant. They are not known to have intruded Neoproterozoic strata. U-Pb zircon dates for these intrusive rocks resulted in an age of $651 \pm 5 \mathrm{Ma}$ for the Ramey Ridge and Rush Creek Point suites and $661 \pm 7 \mathrm{Ma}$ for the Acorn Butte suite (J.N. Aleinikoff, K.V. Evans, and K. Lund, unpub. data, 2003) and indicate that these plutons are Neoproterozoic intrusives that are about 30 m.y. younger than the Neoproterozoic volcanic rocks that are described herein (Edwardsburg Formation, Ze).

Chemical analysis of the Ramey Ridge suite (Leonard, 1963) indicates that both the syenite and diorite are metaluminous alkalic-series rocks. Alkali ratios show that the syenite is sodic whereas the diorite is average to slightly potassic. This chemistry suggests a rift-related origin for the magma. The strong west-northwest alignment of the plutons is notable. The trend suggests that they were emplaced along a Neoproterozoic rift-related fault system that was also related to formation of the Neoproterozoic volcanic rocks (Edwardsburg Formation). The syenite-diorite plutons are also related to the Neoproterozoic and early Paleozoic rifting event(s) that initiated formation of the Cordilleran miogeocline. 
Precious-metal quartz-vein deposits in lenticular veins occupy shear zones in the Ramey Ridge and Acorn Butte syenite-diorite suites. The quartz is coarse grained and banded with pyrite, chalcopyrite, pyrrhotite, and minor galena. Gold was the primary metal produced, silver was less important, and antimony and copper were produced from a few localities (Bookstrom and others, 1998). The age and origin of the mineral deposits is unknown. What little is known about these deposits indicates similarity to Late Cretaceous vein deposits, such as in the Edwardsburg mining district. Although there are no nearby exposures of Late Cretaceous granite to have provided the mineralizing fluids as in the case of mining districts in the east-central part of the forest (fig. A4), preliminary ${ }^{40} \mathrm{Ar} /{ }^{39} \mathrm{Ar}$ ages range from about 79 to $65 \mathrm{Ma}(\mathrm{K}$. Lund and M.J. Kunk, unpub. data, 2001); it is not known if these reflect regional cooling or approximate mineralization ages. Although Late Cretaceous granite possibly underlies this area, cross-section reconstructions indicate that the top of such granite would have to be several kilometers below the vein systems, perhaps too deep to have been the source of mineralizing fluids.

\section{Neoproterozoic and Cambrian(?) Marble}

Gray marble (€Zgm) is the uppermost unit of the Neoproterozoic and Cambrian(?) strata. The color ranges from dark gray, through medium gray, to light tan and is not a good diagnostic feature of the unit, probably reflecting alteration conditions. The marble is mostly calcareous and has minor dolomitic beds. Carbonate minerals are medium grained; coarse-grained, unoriented tremolite-actinolite crystals are fairly common. This unit is recognized in the Stibnite roof pendant, where previous mapping differentiated two carbonate units based on color (Smitherman, 1985), and in the Gospel Peaks roof pendant (K. Lund, unpub. data, 1983). Because of recrystallization and growth of metamorphic minerals, no younging indicators have been found. Fossils were previously reported from this unit (Lewis and Lewis, 1982) but none were found during this study and it is possible that the reported fossils were calc-silicate minerals (B.F. Leonard, USGS, oral commun., 1983).

\section{Early Ordovician-Late Cambrian Syenite-Diorite Pluton}

On the far east side of plate 2, the Yellowjacket suite $\left(\mathrm{O} \epsilon_{s d}\right)$ is a syenite-diorite pluton that forms a southeastern extension of the zone of Neoproterozoic syenite-diorite plutons (Zsd). Although compositionally similar to the older plutons, it has been dated as Early Ordovician or possibly Late Cambrian, about $491 \pm 4$ Ma (J.N. Aleinikoff, K.V. Evans, and K. Lund, unpub. data, 2003). This pluton gives evidence that extensional faulting along a northwest-southeast trend across central Idaho was long lived from the Neoproterozoic to early Ordovician.

\section{Undivided Metamorphic Strata}

Quartzite, feldspathic quartzite, calc-silicate gneiss, biotite gneiss, micaceous schist, and amphibolite (ZYs) are exposed as screens and schlieren along the east side of the Salmon River suture. These were not mapped separately because of limited local preservation and no consistent sense of relationships among lithodemic units (M.A. Kuntz, USGS, oral commun., 1995). The discontinuous nature was caused by intense deformation and metamorphism during suturing and engulfment by syndeformational intrusions. These screens are separated from other metamorphic strata by the Lake CreekSecesh River fault (fig. A3), which may be a normal fault reactivation of a regionally important thrust fault (K. Lund, unpub. data, 2001). These rocks may have originated as strata of a different age or environment than other strata in the forest. Undivided metamorphic rocks are also mapped in the southeastern part of the forest where, because of access and time, rocks in roof pendants could not be remapped and subdivided during this study. Available exposures or previous descriptions of these rocks are so limited that it is not possible at present to subdivide them into Mesoproterozoic or Neoproterozoic packages.

\section{Rocks of Island-Arc Derivation}

\section{Metamorphic Rocks of Blue Mountains Island Arc}

Metamorphic rocks of oceanic island-arc derivation in the forest include mafic through silicic island-arc volcanic and plutonic rocks, volcaniclastic sedimentary rocks, carbonate rocks, and island-arc basement. Four oceanic metamorphic terranes have been identified in the forest; these correlate with terranes that cross from central Oregon into Idaho in a northeast-trending belt (Silberling and others, 1992). The four terranes include two volcanic arc successions (Wallowa and Olds Ferry terranes), a fore-arc basin-accretionary prism (Baker terrane), and an intra-arc basin (Izee terrane) that represent parts of the Blue Mountains island arc. The terranes had complex overlapping deposition during syndepositional Late Triassic dismemberment and were subsequently stacked (fig. A3) upon each other during late Middle Jurassic to Early Cretaceous amalgamation (Walker, 1989; Vallier, 1995) along what are now steep, west-dipping faults and shear zones (Mann, 1991). During and before amalgamation, these terranes underwent local low-grade metamorphism and ductile deformation.

During the Cretaceous, they were sutured to Laurentia along the Salmon River suture, resulting in widespread, overprinting metamorphic and deformational events. During suturing, these metamorphic rocks were stacked in reverse metamorphic sequence (higher grade overlying lower grade) along east-dipping thrust faults that steepen nearer the suture (see "Cretaceous Deformation" section). Near the suture, 
island-arc rocks have undergone intense ductile deformation, metamorphism to partial melt conditions, and intrusion. Thus, the eastern edge of the oceanic rocks are so changed by the processes of accretion that the terrane(s) they belong to, their age, and much of their original context is unknown (Hamilton, 1963; Lund, 1984; Onasch, 1987; Lund and Snee, 1988; Blake, 1991; Selverstone and others, 1992; Lund, 1995; Lund and others, 1997).

\section{Baker Terrane}

Rocks of the Baker terrane (Silberling and others, 1992) were previously called the dismembered oceanic crust terrane (Brooks and Vallier, 1978) and the central melange terrane (Dickinson, 1979). In Oregon, the Baker terrane is a strongly deformed succession of rocks primarily consisting of melange that probably originated in an accretionary wedge fore-arc environment (Brooks and Vallier, 1978; Dickinson, 1979; Walker, 1995). In the forest, exposures include deformed phyllite, cherty phyllite, and limestone that probably originated in a fore-arc basin environment (Mann, 1991). The interbedded cherty and fine-grained clastic nature of the phyllite reflects deep-water deposition by turbidity currents. The noticeable lack of conglomeratic and coarse clastic rocks in the Baker terrane reflects a deeper water, more stable environment than that of the other three terranes.

\section{Wallowa Terrane}

The Wallowa terrane (Silberling and others, 1992) was originally called the Wallowa Mountains-Seven Devils island arc (Brooks and Vallier, 1978) and the Seven Devils terrane (Dickinson and Thayer, 1978). The Wallowa terrane is interpreted to be a Permian to Triassic volcanic island arc built on metamorphosed plutonic-oceanic basement ( $M z P z n)$, exposed at The Oxbow (Vallier, 1977; Ave Lallemant and others, 1980) on the Snake River (west-central edge pl. 1). The oldest volcanic rocks in the island arc are the Windy Ridge Formation (Psw) of the Seven Devils Group, which formed as accumulations from local volcanic vent sources. The overlying Hunsaker Creek Formation (Psh) of the Seven Devils Group is mainly pyroclastic rocks of a more silicic composition. This formation marked the onset of widespread subduction-related arc volcanism (Vallier, 1977). An unconformity at the top of the Hunsaker Creek Formation represents an Early Permian to Middle Triassic volcanic hiatus in formation of the island arc. During this hiatus, Late Permian pre-tectonic gabbro, diorite $(\mathrm{Pd})$, and syntectonic quartz diorite $(\mathrm{Pqd})$ plutons were intruded into the basement (MzPzgn) between 249 and $259 \mathrm{Ma}$ (Walker, 1986) and mylonitic deformation occurred along the Oxbow-Cuprum shear zone in the basement rocks.

The upper two units of the Seven Devils Group, the Wild Sheep Creek and Doyle Creek Formations (Ksw and ksd, respectively), are primarily flows and volcaniclastic rocks in contrast to the more silicic pyroclastic rocks of the
Hunsaker Creek Formation. The Triassic part of the Wallowa volcanic island arc was fringed and overlain by Upper Triassic carbonate rocks and shales of the Martin Bridge Formation $(\mathrm{km})$, which formed in carbonate platform, slope, and basin environments. Carbonate and basinal environments became more dominant as arc volcanism waned in the Triassic (Lund, Scholten, and McCollough, 1983; Lund and others, 1993; Follo, 1994; Lund, 1995) but fossil evidence indicates equatorial latitudes in Pacific environments (summarized in White and others, 1992). Middle Jurassic rocks at the top of the Wallowa terrane $(20 \mathrm{~km}$ northwest of the northwestern corner of the forest) include fluvial and ash-flow deposits and fossil assemblages with some North American affinity. This suggests change of environments possibly in response to beginning accretion processes (White and others, 1992) at the same time as plutons (Bald Mountain and Wallowa batholiths) intruded the Wallowa terrane and metamorphosed volcanic/plutonic complex.

Intermediate-composition volcanic and dome-complex rocks of the Hunsaker Creek Formation host volcanogenic massive sulfide deposits (Bookstrom and others, 1998). The deposits are stacked layers of stratiform massive sulfide and strata-bound sulfide veinlets. The mineralogy includes pyrite, chalcopyrite, sphalerite, barite, and in places galena. Mineralized breccia and exhalatives are also part of the deposits (Fifarek and others, 1994).

\section{Olds Ferry Terrane}

The volcanic island-arc succession called the Huntington Formation (kh) forms the Olds Ferry terrane (Silberling and others, 1984; Silberling and others, 1992), which was originally named the Juniper Mountain-Cuddy Mountain volcanic arc (Brooks and Vallier, 1978) and later the Huntington arc terrane (Dickinson, 1979). The greenstone volcanic, volcaniclastic, and minor chert and carbonate rocks formed in a Middle to Late Triassic volcanic island arc. It has been suggested that the Olds Ferry island arc was built on part of the oceanic crust and fore-arc basin rocks of the Baker terrane during renewed volcanism after a change in orientation of subduction caused volcanic activity to wane in the Wallowa terrane (Vallier, 1995). However, it should be noted that the volcanic rocks of the Huntington Formation are essentially coeval with the Wild Sheep Creek and Doyle Creek Formations of the Wallowa terrane ( $\mathrm{kwS}$ and $\mathrm{kwd}$, see preceding discussion).

Intermediate-composition plutons, which include porphyritic biotite granodiorite ( $\mathrm{kgd}$ ), hornblende-biotite quartz diorite ( $\mathrm{kqd}$ ), and porphyritic hornblende gabbro ( $\mathrm{kqb}$ ), crop out extensively in the Hitt Mountains and at Cuddy Mountain (southwestern and western pl. 1, respectively), southeast of exposures of the Huntington Formation (west-central pl. 1) that they intruded. Mapping suggests that they are in contact with rocks of the Izee terrane in the Hitt Mountains but, because the plutons are thought to be older than rocks of the Weatherby Formation (Izee terrane), more information on possible depositional or structural relationships and age data on 
the plutons are needed. The plutons are a spatially and genetically related sequence, as documented in the Hitt Mountains (Henricksen, 1975) and Cuddy Mountain (Bruce, 1971). K-Ar ages are not well constrained and some of the isotopic dates conflict with the relative ages determined from crosscutting relations (Bruce, 1971; Henricksen, 1975). K-Ar data on hornblende and biotite for these intermediate-composition plutons give preliminary cooling ages between about 225 and $182 \mathrm{Ma}$. Preliminary U-Pb zircon data indicate that both the youngest of the units, granodiorite (kgd), and the oldest, gabbro ( $\mathrm{kqb}$ ), are about $220 \mathrm{Ma}$ (K. Lund and D.M. Unruh, unpub. data, 2002). Their exposure is partly due to normal faulting that formed the Hitt Mountains and Cuddy Mountain and possibly to an east-directed structure that juxtaposed the Olds Ferry terrane against other island-arc rocks to the east but that is mostly hidden beneath basalt flows in the Weiser embayment.

A number of porphyry copper systems have been identified in the Mineral and Cuddy Mountain mining districts (fig. A4) of the Hitt Mountains and Cuddy Mountain, respectively (Bookstrom and others, 1998). These are thought to be genetically related to porphyritic biotite granodiorite and tonalite ( $\mathrm{kgd}$ ), which is one of the younger intrusive units, and to associated minor porphyry and aplite intrusions (Field and others, 1975) that are undated. These rocks are probably exposed due to faults active before the area was covered by basalt flows of the Weiser embayment and that may have controlled development of that north-trending basin.

\section{Izee Terrane}

The Izee terrane (Silberling and others, 1992) was previously called the flysch terrane (Brooks and Vallier, 1978). The principal unit in the Izee terrane, the Weatherby Formation (Jws), is interpreted to have been deposited in a fore-arc basin (Dickinson and Thayer, 1978; Dickinson, 1979) or intra-arc basin setting (Vallier, 1995) on top of the Olds Ferry terrane (Brooks and Vallier, 1978). Turbiditic sandstone and shale in the Weatherby Formation (Jws) have both volcaniclastic and cherty constituents that were derived from the volcanic Huntington Formation ( $\mathrm{kh}$ ) of the Olds Ferry terrane and from the oceanic crust rocks of the Baker terrane ( $\left.\mathrm{Mz}_{\mathrm{z}} \mathrm{b}\right)$, respectively. Volcanic conglomerates of the Weatherby Formation were derived from the Huntington Formation. Individually mapped andesite and rhyolite tuff units (Jwa and Jwr, respectively) in the Weatherby Formation indicate that volcanism was ongoing during formation of the Izee terrane. These conclusions are based on observations that the Weatherby Formation was unconformably deposited on the Huntington Formation (Slater, 1969; Bruce, 1971; Brooks and Vallier, 1978) but was also partly thrust over the Huntington Formation (Izee terrane over Olds Ferry terrane) in the Jurassic (Livingston, 1932; Skurla, 1974; Henricksen, 1975) during amalgamation of the Blue Mountains island arc (Vallier, 1995). The Weatherby Formation is partly coeval with and possibly related to Middle Jurassic rocks at the top of the Wallowa terrane northwest of the forest (White and others, 1992).

\section{Metamorphosed Volcanic/Plutonic Complex}

The metamorphosed volcanic/plutonic complex (KJPvp) consists of highly deformed, high-grade island-arc rocks and highly deformed plutonic rocks that are in places so mixed as to be indistinguishable at this scale. This unit lies in an elongate belt on the west side of the Salmon River suture (fig. A3; eastern pl. 1). Both the volcanic and plutonic parts of the complex underwent intense ductile deformation during suturing that completely obliterated original features (fig. B6); the unit looks remarkably like zones in the Canyon Mountain Complex in the Baker terrane of Oregon (Bishop, 1995). Cores of garnets in amphibolites related to this complex (from JPam) were dated as pre-144 Ma and two-stage garnets were dated at about $128 \mathrm{Ma}$ (Selverstone and others, 1992; Getty and others, 1993). The Jurassic plutons (KJtf) were cut by Early Cretaceous deformed plutons and dikes at about $110 \mathrm{Ma}$ (D.M. Unruh and K. Lund, unpub. data, 2002) and $118 \pm 5 \mathrm{Ma}$ (Manduca, 1988; Manduca and others, 1993), which are the same age as, and probably related to units of, the Salmon River suture complex (Kgn and Kpgdm). The dates on metamorphic garnets indicate that these metavolcanic rocks formed prior to Jurassic plutonism in the Wallowa terrane, metamorphism and deformation during the Late Jurassic to Early Cretaceous, and Early Cretaceous intrusions related to the Salmon River suture zone complex (Kgn, see next section).

Along the eastern side of the oceanic terranes, higher grade island-arc rocks are intermixed with intrusive rock and structurally juxtaposed against lower grade Wallowa terrane, and isolated from the other terranes by the intervening basalt cover of the Weiser embayment (fig. A3). These factors make it difficult to use field observations to determine possible correlations among the high-grade oceanic rocks and the named island-arc terranes. In areas where the metavolcanic rocks are mapped separately from metaplutonic rocks and not combined into the metamorphosed volcanic/plutonic complex (KJPvp), they are mapped as undivided metamorphic rocks (JPmv) or amphibolite gneiss (JPam), or correlated with units of the Riggins Group (JPrs, JPrl, JPrf; Hamilton, 1963; Onasch, 1977, 1987; Lund, 1984; Aliberti, 1988; Manduca, 1988; Lund and others, 1993). Preliminary Nd-Sm dates of pre-144 Ma metamorphism from amphibolite gneiss near Pollock Mountain (JPam; northeastern pl. 1; Selverstone and others, 1992; Getty and others, 1993) and U-Pb dates of about $160 \mathrm{Ma}$ on crosscutting plutons (see following) indicate that the rocks are pre-Late Jurassic. These rocks may correlate with some of the terranes in the Blue Mountains island arc (Lund, 1984; Lund and Snee, 1988; Silberling and others, 1992; Lund and others, 1993; Vallier, 1995) or with unknown terranes caught between the oceanic terranes and Laurentia. Intermediate-composition metavolcanic rocks, mapped as unit JPmv at Peck Mountain, $5 \mathrm{~km}$ northeast of Hornet Ranger Station (central pl. 1), host a volcanogenic massive sulfide deposit. These rocks may be part of the Olds Ferry terrane based on mineral deposit characteristics and on being along trend with that terrane (Mangham, 1994). 
The metamorphosed volcanic/plutonic complex (KJPvp) includes foliated tonalite plutons (KJtf) that are mapped separately in some areas in the Little Salmon and Weiser River drainages and that are dated by U-Pb zircon at about 160 and $158 \mathrm{Ma}$ (D.M. Unruh, J.N. Aleinikoff, K. Lund, unpub. data, 2002). These plutons are about the same age as the Bald Mountain and Wallowa batholiths in the Wallowa terrane of Oregon (Armstrong and others, 1977) and were intruded in the earliest Late Jurassic at about the same time as end of deposition of the volcanic and volcanogenic sedimentary rocks in the Izee and Wallowa terranes. The similar ages may provide a link for correlating the high-grade metamorphic gneisses of the metamorphosed volcanic/plutonic complex (KJPvp, JPmv, JPam) and Riggins Group (JPrs, JPrl, JPrf) with the Wallowa terrane. Plutonic rocks in this unit are cut by minor Early Cretaceous intrusions that are not mapped separately but have been dated at about $110 \mathrm{Ma}$ (K. Lund and D.M. Unruh, unpub. data, 2001) and $118 \mathrm{Ma}$ (Manduca and others, 1993) and are related to the plutonic rocks of the heterogeneous orthogneiss complex.

\section{Post-Amalgamation Intrusive Rocks}

In the southern Seven Devils Mountains, the Deep Creek pluton (Cannon and others, in Hamilton, 1963; White, 1968, 1973; north-central pl. 1) is dated by K-Ar on hornblende at about $137 \mathrm{Ma}$ (Armstrong and others, 1977; recalculated by Walker, 1986). A greenschist metamorphosed tonalite in the lower Rapid River (Hamilton, 1963; Aliberti, 1988) is dated by ${ }^{40} \mathrm{Ar} /{ }^{39} \mathrm{Ar}$ on hornblende at $145.1 \pm 1.5 \mathrm{Ma}$ (Snee and others, 1995). The K-Ar dates are probably minimum ages of emplacement (Walker, 1986). The Deep Creek and nearby Echols Mountain plutons were intruded across the earlier deformation belt of the Oxbow-Cuprum shear zone (Cook, 1954; Cannon and others, in Hamilton, 1963; Vallier, 1967, 1995; White, 1968, 1973). All three plutons intruded marble and volcaniclastic rocks that are herein considered to be the Triassic parts of the Wallowa terrane, mostly the Triassic Martin Bridge Formation ( $\mathrm{km}$ ) and the Doyle Creek Formation ( ksd; interpreted from descriptions in Cook, 1954; Cannon and others, in Hamilton, 1963; White, 1968, 1973; Onasch, 1977; Gualtieri and Simmons, 1978; G.C. Simmons, USGS, unpub. data, 1980; Aliberti, 1988). Foliation in the Deep Creek and Echols Mountain plutons was interpreted either to be tectonic (Cook, 1954; Hamilton, 1963) or flow foliation (White, 1968, 1973). Plutons of this age have been mapped in the Clearwater National Forest (Davidson, 1990; about $100 \mathrm{~km}$ north of pl. 1) and provide evidence of latest Jurassic to Early Cretaceous magmatism in the oceanic rocks from northeastern Oregon to north-central Idaho. This magmatism may have been related to amalgamation processes (Walker, 1986) or to early accretionary processes, both occurring after building of the Blue Mountains island arc had ceased in the Jurassic.

\section{Salmon River Suture Zone Complex}

The deformed heterogeneous unit of porphyritic granodiorite and hornblende tonalite gneiss (Kgn and, where mapped separately, porphyritic granodiorite gneiss, Kpgdm) straddle the suture (Manduca, 1988). The porphyritic granodiorite gneiss $(\mathrm{Kpgdm})$ is differentiated from the heterogeneous orthogneiss complex (Kgn) in a large unmixed body forming much of the West Mountains (Bonnichsen, 1987; east-central pl. 1). The porphyritic granodiorite gneiss is dated at $115 \pm 1 \mathrm{Ma}$ (SHRIMP U-Pb zircon age by K. Lund, J.N. Aleinikoff, D.M. Unruh, unpub. data, 2002; previously dated at $111 \pm 5$ Ma by Manduca, 1988). Related minor intrusions cutting the metamorphosed volcanic/plutonic complex (KJPvp) are between 110 and $118 \mathrm{Ma}$ (see preceding section). The initial strontium isotope values in the plutonic rocks show a sharp increase across the complex from "oceanic" values $(<0.704)$ in the west to "continental" values $(>0.706)$ in the east (Armstrong and others, 1977; Fleck and Criss, 1985). The location of this sharp increase is taken as the location of the suture between continental and oceanic basement (Lund, 1984; Ave Lallemant and others, 1985; Lund and Snee, 1988), the Salmon River suture (fig. A3). Plutonic rocks of this complex were interpreted to have been localized in response to intense transpressional deformation and emplaced at deep crustal levels (Zen and Hammarstrom, 1984; Zen, 1985). Steeply inclined to vertical foliation and (or) lineation and, in places, mylonite fabrics are superposed on the heterogeneous orthogneiss complex (Manduca, 1988; Manduca and others, 1993; Lund and others, 1997). The mylonites and discrete shear zones define the Western Idaho shear zone (Fleck and Criss, 1985; Manduca, 1988; Strayer, 1988; Strayer and others, 1989), probably a discrete young shearing within the broader, longer-lived Salmon River suture (see "Structure" section).

\section{Late Cretaceous Idaho Batholith}

The Late Cretaceous Idaho batholith consists of two plutonic series that were emplaced sequentially. These two plutonic series are significantly more distinct in terms of time, conditions of emplacement, and composition than is commonly recognized. The older series plutons (plus strongly deformed plutonic rocks in the suture zone, Kgn and Kpgdm, and some of the deformed plutonic rocks in the metamorphosed volcanic/ plutonic complex, KJPvp) have been called the "border zone of the Idaho batholith" (Hamilton, 1963, 1969). However, the plutonic rocks of the metamorphosed volcanic/plutonic complex (KJPvp) and Salmon River suture complex (Kgn and Kpgdm) are considerably (more than $20 \mathrm{Ma}$ ) older than the Idaho batholith and presumably at least partially allochthonous.

The older plutonic series of the Idaho batholith includes a variety of composite, intermediate-composition plutons and was emplaced east of the Salmon River suture. Mafic mineral-rich porphyritic granodiorite (Kpgdf) is about $93 \mathrm{Ma}$ (K. Lund and D.M. Unruh, unpub. data, 2002) and intruded 
only in the south-central part of the forest (southwestern pl. 2) probably along early compressional structures. Foliated hornblende-biotite tonalite (Ktf) and foliated biotite granodiorite (Kgdf) intruded between 91 and $89 \mathrm{Ma}$ (K. Lund, J.N. Aleinikoff, and D.M. Unruh, unpub. data, 2002). Near the suture zone, plutons of the older plutonic series (Ktf and Kpgdf) are elongated parallel to the suture and are internally strongly foliated and lineated (Lund, 1984; Manduca and others, 1993). Farther east from the suture, the elongation of plutons and formation of internal fabrics are not as strongly developed. Remnants of the older plutonic series are preserved throughout central Idaho along the margins and as roof pendants to the younger series (Lund and others, 1997). Primary epidote in these plutons suggests emplacement at crustal depths of about $30 \mathrm{~km}$ (Zen and Hammarstrom, 1984; Zen, 1985). Following emplacement of the older plutonic series, uplift and erosion on the continental side of the suture stripped as much as $10 \mathrm{~km}$ of crust prior to emplacement of the younger plutonic series at shallower crustal depths (Lund and Snee, 1988; Lund, 1995).

The voluminous younger plutonic series is composed of marginally peraluminous granites that form the core and "main phase" of the Idaho batholith. The younger plutonic series was emplaced east of the suture (Lund, 1984; Lund and Snee, 1988; Manduca and others, 1993; Lund and others, 1997) between 87 and $78 \mathrm{Ma}$ (K. Lund, J.N. Aleinikoff, and D.M. Unruh, unpub. data, 2001-2002) and forms most of the plutonic rocks in the eastern part of the forest. This younger plutonic series consists of rare-earth-element-bearing porphyritic muscovite-biotite granite/granodiorite (Kpg; Schmidt, 1964) and biotite-muscovite granite $(\mathrm{Kg})$. Although direct crosscutting contacts were not observed in the field, map relations consistently show that the biotite-muscovite granite $(\mathrm{Kg})$ cuts and forms a core to the porphyritic muscovite-biotite granite/granodiorite (Kpg; east-central pl. 2). These plutons intruded into continental metamorphic rocks and into and above the roof zone of the older plutonic series at shallower crustal depths of 6-9 km (Lund and others, 1986). The younger plutonic series intruded passively into the country rocks, thereby preserving pre-intrusion stratigraphy, metamorphic gradients, and structures.

Slow cooling and uplift of the region followed emplacement of the younger plutonic series (Lund and others, 1986). The roof zone of the porphyritic muscovite-biotite granite/granodiorite (Kpg) is the site of the precious-metal quartz-vein deposits in the mining districts of Warren, Resort, and Marshall Lake (fig. A4) that formed about 74.5 Ma (K. Lund, unpub. data, 1990). These vein systems formed in cooling fractures at or just above the roof of the Idaho batholith (Lund and others, 1986; Lund and Esparza, 1990). Precious-metal quartz-vein deposits to the east in the forest are also Late Cretaceous (Gammons, 1988), probably related to the biotite-muscovite granite (Kg; Lund and others, 1986). Precious-metal vein deposits (Bookstrom and others, 1998) have been mined by adits (in the case of discrete veins), by open pits (in the case of more disseminated deposits), and by eluvial placering (where chemical weathering resulted in enrichment of bedrock deposits).

\section{Eocene Challis Magmatic Complex}

A younger magmatic event cut the Idaho batholith in the eastern part of the forest and formed the Eocene Challis Volcanic Group and associated hypabyssal dikes and plutons that are herein called the Challis magmatic complex. The specific relations between intrusive and extrusive rocks in the Challis magmatic complex have not been documented because field relations between them have not been well studied and dating has not been well integrated with field mapping. The only Eocene plutonic rock that has been dated in the forest is pink hornblende-biotite granite ( $\mathrm{Tg}$ ) of the Casto pluton. Two fairly different $\mathrm{K}-\mathrm{Ar}$ ages are reported: one biotite age is $43.9 \pm 1.3$ Ma (Armstrong and others, 1977) and the other is 47.8 \pm 1.9 Ma (Leonard and Marvin, 1982), which probably reflect cooling rather than differing emplacement. No rocks from the newly described Chamberlain Basin or Savage Point plutons have been dated. K-Ar ages from the study of the Challis $1^{\circ} \times 2^{\circ}$ quadrangle to the south and east of the forest indicate that, in general, ranges in dates for some of the extrusive rocks are older than most dates for plutonic rocks (Fisher and others, 1992) but also that most of the dates overlap. Dates for plutonic rocks are some of the youngest; this probably reflects slower cooling rates for plutons than for extrusive rocks. Thus, the volcanic and plutonic rocks are essentially coeval, indicating a magmatic event ranging from about 51 to $39 \mathrm{Ma}$.

During this Eocene event, magma rose to near-surface depths and occasionally vented, commonly resulting in caldera complexes. Other magma cooled in the upper crust 2-4 km below the surface, as evidenced by miarolitic cavities, and formed shallowly emplaced (epizonal) plutons (Rehn and Lund, 1981). In places, plutonic rocks can be shown to intrude volcanic ejecta and in other places evidence has been found that the top of a pluton breached the surface and erupted (Fisher and others, 1992).

Although not linked directly by isotopic studies or by observed field relations, the present information is herein interpreted as showing that phases of intrusive and extrusive rocks have a parallel compositional sequence. The earliest phase of volcanism in the Challis volcanic field produced intermediate and mafic lavas, the middle period of volcanic activity produced rhyodacite ash-flow tuffs, and the youngest phase of volcanism produced alkali-rhyolite ash-flow tuffs (McIntyre and others, 1982). In parallel sequence (Fisher and others, 1992; Lund and others, 1997; K. Lund, unpub. data, 1992), the oldest phases of the Casto, Chamberlain Basin, and Savage Point plutons (fig. A3) are granodiorite and diorite, the main phase of the Chamberlain Basin and Savage Point plutons and a less important phase of the Casto pluton are porphyritic gray monzogranites, and the youngest phases of the three plutons are syenogranites, usually pink in color. 


\section{Challis Volcanic Group}

The Challis Volcanic Group is a voluminous succession of Eocene rhyolitic to dacitic tuffs and lavas and minor volcaniclastic sedimentary rocks. The major exposures of this group are southeast of the forest but parts of two caldera complexes have been recognized by previous workers (Fisher and others, 1992) in the southeastern part of the forest (pl. 2) - the Van Horn Peak and Thunder Mountain calderas. The volcanic rocks in the east-central part of the forest are undivided because of the reconnaissance nature of available mapping (Cater and others, 1973). Throughout the east-central part of the forest, boundaries of the volcanic rocks were not well delineated by the reconnaissance mapping, and brief examination during the present study demonstrated that some contacts may be mislocated by several kilometers.

The tuff of Ellis Creek (Tce) formed during the voluminous eruption that triggered subsidence of the Van Horn Peak caldera (Fisher and others, 1992). More of this unit is probably included in the eastern side of the undivided Challis Volcanic Group (Tc). Although ages are inconclusive, mapping suggests that extrusion of this unit preceded subsidence of the Thunder Mountain caldera.

Most of the Challis Volcanic Group in the forest is part of the Thunder Mountain caldera complex (fig. A3). The geometry of the caldera as a whole is poorly constrained because the rocks have not been subdivided in the northern part of the caldera. Eruptions of the Lapilli tuff (Tct), located along the southeastern and southwestern parts of the caldera, triggered subsidence of the Thunder Mountain caldera (Fisher and others, 1992). Buff rhyolite (Tcbr) is in an equivalent position to the lapilli tuff (Tct) on the western side of the caldera. Ash flow tuff of the perlitic rhyolite (TcP) and lava flows of the lower latite lava (Tcll) form thin units in the caldera complex. The most voluminous rocks in the caldera are the Sunnyside tuff (Tcs), an informal unit that only locally has been subdivided on previous maps (Shannon and Reynolds, 1975; Fisher and others, 1992). The rocks that have received the most interest are in the Thunder Mountain mining district (fig. A4). The latite of Lookout Mountain (Tcl) and the volcaniclastic rocks of Dewey mine (Tcd) are the youngest strata of the Thunder Mountain caldera complex (Ross, 1933; Fisher and others, 1992) and are genetically related to hydrothermal fluids that formed gold deposits in the caldera. Carbonaceous plant remains in the volcaniclastic rocks of Dewey mine (Tcd), which are mostly mudflow or lahar deposits, chemically fixed the gold that was mined at the Dewey mine (central pl. 2; Ross, 1933). The Dewey mine, the recently mined Sunnyside deposit, and other related deposits (central pl. 2) are hotspring-type gold-silver deposits (Bookstrom and others, 1998).

Although hosted by Late Cretaceous granite and older metasedimentary rocks, the Hermes mercury deposit and other nearby related prospects and small deposits along the western margin of the Thunder Mountain caldera in the eastern Yellow
Pine mining district (fig. A4; central pl. 2) are probably related to the Thunder Mountain caldera (fig. A3). This association of the Hermes mine and related deposits with the Thunder Mountain caldera seems most favorable given that these are probably hot-spring-type mercury deposits (Bookstrom and others, 1998).

\section{Hypabyssal Intrusive Rocks}

Several major dike swarms are mapped in the central and eastern parts of the forest (pl. 2). The Pistol Creek dike swarm (south-central pl. 2 and fig. A3; Fisher and others, 1992) and parts of the Profile Gap-Smith Creek dike swarm (central pl. 2; east-central fig. A3; Shenon and Ross, 1936; Lund and others, 1997) were previously described. The dikes (Tpr) in these two swarms strike north-northeast and have steep to vertical dips. West of the Johnson Creek-Profile Gap shear zone and south of and parallel to the Savage Point pluton (fig. A3; central pl. 2), the east-northeast-striking Rainbow Ridge dike swarm and minor parallel dikes near Van Meter Hill north of Yellow Pine (central pl. 2; Lund and others, 1997) have steep to vertical dips but strike east-northeast, as do compositional and textural units in the Savage Point pluton (fig. A3; central pl. 2; Lund and others, 1997). From field relations, these dikes apparently are in the roof zone of unexposed or partially exposed Eocene plutons where magma from the top of a magma chamber escaped into brittle fractures that followed regional fracture patterns. The Profile Gap-Smith Creek dike swarm follows the Johnson Creek-Profile Gap shear zone. However, the Rainbow Ridge dike swarm, Savage Point pluton, and dikes near Van Meter Hill are probably in extension fractures related to and west of the Johnson Creek-Profile Gap shear zone. They are probably oriented in response to tension fracturing related to movement along that strike-slip fault zone (Lund and others, 1997; see "Tertiary Deformation" section).

Other unnamed rhyolitic dike (Tpr) swarms are found along the Middle Fork of the Salmon River on the east side of the forest and near the southeast corner of plate 2. Many of the dike swarms along the Middle Fork of the Salmon River on the south side of the mouth of Big Creek and directly southeast of the forest boundary (eastern pl. 2) have shallow to horizontal dips and seem to form "sills" or areas of lesser accumulation of magma between adjacent Eocene magma bodies (fig. A7).

Several new plutons were mapped in the course of this study. The Savage Point pluton has already been described (Lund and others, 1997). What was informally called the Wolf Fang Peak complex in Lund and others (1997) is the southwestern arm of the complex roof zone of the much larger (but at that time unrecognized) Chamberlain Basin pluton, which is first recognized as an Eocene pluton and named in this report. The use of "Wolf Fang Peak complex" as a separate plutonic body is discarded. The Big Horn Crags pluton (Cater and 
others, 1973; east edge pl. 2) is herein shown to be an eastern extension of, and an individual intrusive unit in, the huge Chamberlain Basin pluton, by far the largest Eocene plutonic complex in Idaho.

The Eocene epizonal plutons (fig. A3) are complex bodies. Access was insufficient to map out different intrusions and cooling units in the Chamberlain Basin pluton but several compositional as well as textural phases were noted; it is a compositionally complicated plutonic complex. Compositional and textural varieties are mapped in the Savage Point pluton (Lund and others, 1997) and parts of the Casto pluton (Fisher and others, 1992). The two main compositional varieties are medium- to coarse-grained, pink hornblende-biotite syenogranite and porphyritic, medium-grained, gray hornblende-biotite monzogranite. Both compositional varieties are combined in unit $\mathrm{Tg}$ on plate 2 because insufficient information exists to subdivide the unit throughout the map area. Most of the Casto pluton is the pink syenogranite. Both the eastern (previously named Big Horn Crags pluton of Cater and others, 1973) and western parts of the Chamberlain Basin pluton are known to be pink syenogranite but most of the center of this pluton is porphyritic gray monzogranite. The Savage Point pluton has several textural phases of gray monzogranite (Lund and others, 1997). Field relations suggest that, in each case, the monzogranite may be slightly older and somewhat more deeply emplaced than the syenogranite.

Granite porphyry (Tgp), containing common miarolitic cavities, represents chilled marginal or roof facies of either variety of granite $(\mathrm{Tg})$. The granite porphyry of the Savage Point pluton is pink syenogranite porphyry containing abundant well-developed miarolitic cavities. K-Ar dates for granite porphyry (Tgp) given in Fisher and others (1992) are slightly older than those of granite $(\mathrm{Tg})$; more rapid cooling rather than separate intrusion is probably responsible but specific dating studies of these textural phases have not been undertaken.

Minor hornblende-biotite granodiorite (Tgd) was the initial intrusion of the Savage Point pluton. Similar early diorite bodies ( $\mathrm{Td}$ ) are found in the western part of the Chamberlain Basin pluton (north-central pl. 2) and are associated with the Casto pluton (southeastern pl. 2).

Composite three-dimensional views of the plutons and their host setting are beginning to emerge as a consequence of the mapping for this study area, the Challis $1^{\circ} \times 2^{\circ}$ quadrangle (Fisher and others, 1992), and the areas north of the Salmon River (Lund, 1980; Lund, Rehn, and Holloway, 1983; Toth, 1983; Lund and others, 1992). Data from the forest and other

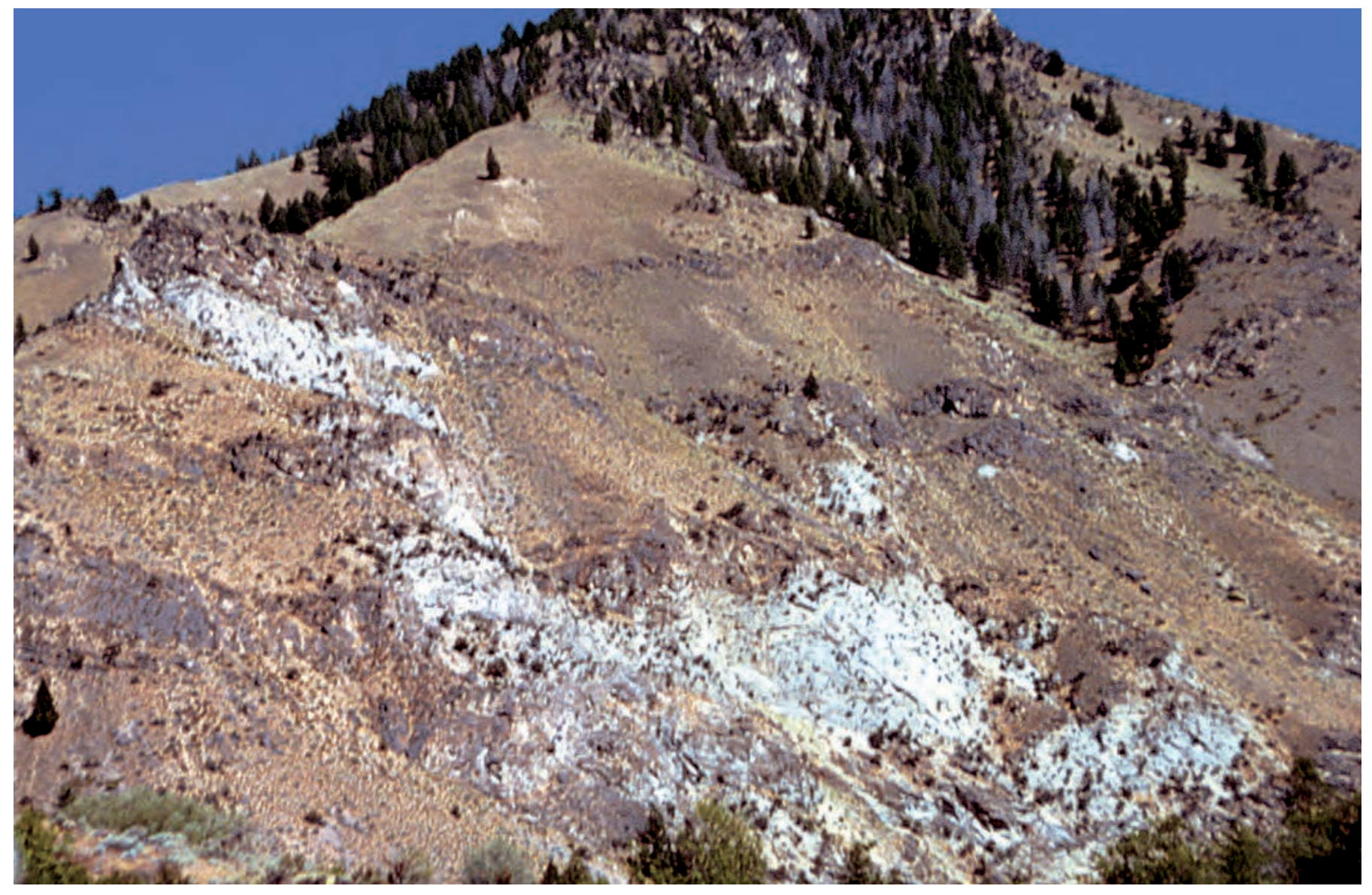

Figure A7. Flat dikes (sills) of Eocene rhyolite cutting Late Cretaceous granite near Sheep Creek on Middle Fork Salmon River (southeastern pl. 2). View looking west. 
plutons to the north (Lund, 1980; Lund, Rehn, and Holloway, 1983; Lund and others, 1992) indicate that Eocene magmas were introduced into the crust in a variety of dike compositions that can be seen beneath Eocene granite bodies and that do not have miarolitic cavities. The magma intruded to near surface levels and coalesced at a depth of 2-4 km (Rehn and Lund, 1981); at times, the magma vented or intruded related volcanic ejecta (Lund, Rehn, and Holloway, 1983; Fisher and others, 1992). The magma formed irregularly shaped sill-like masses, occurring as minor flat-lying dikes (fig. A7) and large relatively thin plutons in the upper crust throughout central Idaho. North-northeast-tending granitic dikes having chill textures, such as common miarolitic cavities, formed in regionally oriented tension fractures as dike swarms (such as the Pistol Creek, Profile Gap-Smith Creek, Rainbow Ridge dike swarms, previously described) at the top of the plutons.

\section{Weiser Embayment}

The southeasternmost lobe of basalt of the Columbia Plateau is called the Weiser embayment (fig. A3). The most voluminous and oldest basalts are part of the Columbia River Basalt Group (Tcr). A younger group of flows, the basalt of Weiser and basalt of Cuddy Mountain (Tw and Tcm), are of more local origin.

\section{Columbia River Basalt Group}

The coarsely porphyritic Imnaha Basalt (Tcri) forms the oldest flows of the Columbia River Basalt Group in the forest. Because they spread farthest to the southeast, the flows of Imnaha Basalt define the Weiser embayment. At least $700 \mathrm{~m}$ of Imnaha Basalt are in the Weiser embayment; individual flows are 20-60 m thick (Fitzgerald, 1982). Imnaha Basalt originated from vents and dikes on both sides of the Snake River along the Oregon-Idaho border (Hooper and Swanson, 1990), including the Brownlee Reservoir area of the forest. As these flows spread eastward across western Idaho, they disrupted drainage on the east side of the Weiser embayment that had flowed westward out of the Salmon River Mountains (Fitzgerald, 1982).

The mostly nonporphyritic (aphyric) flows of the Grande Ronde Basalt (Tcrg) conformably overlie the Imnaha Basalt. Individual flows are thinner, in the 10- to 20-m range, and are more resistant to weathering than the Imnaha Basalt (Fitzgerald, 1982). The Grande Ronde Basalt is the most voluminous unit in the Columbia River Basalt Group (Reidel, 1983) but is less than $300 \mathrm{~m}$ thick in the Weiser embayment (Fitzgerald, 1982). Grande Ronde vents are west of the Imnaha River in Oregon, entirely outside of the forest. The Grande Ronde Basalt flowed into the Weiser embayment from the north and the flows thin southward because of northward structural tilting (Fitzgerald, 1982).

\section{Other Deposits of the Weiser Embayment}

The basalt of Weiser (Tw) accumulated as a great thickness of flows in the center of the north-trending Indian Valley trough of the Weiser embayment (fig. A3; Fitzgerald, 1982). Basalt flows were accompanied by pumice breccia, scoria, and ash especially near vents. Two vents have been recognized; one is east of Cambridge and the other south of Midvale (south-central pl. 1; McIntyre, 1976; Fitzgerald, 1982). Based on the diverse geochemical compositions of the basalt of Weiser and because it is the same age as the basal member of the Strawberry Volcanics of east-central Oregon, these flows are thought to be related to the Strawberry Volcanics rather than to the Columbia River Basalt Group (Hooper and Swanson, 1990).

The basalt of Cuddy Mountain (Tcm) is mapped as a separate unit because it is physically isolated on the Cuddy Mountain uplift. It is geochemically distinct from the other basalt units (Fitzgerald, 1982). Because of its physical isolation, the origin of the basalt of Cuddy Mountain relative to that of rocks of the Columbia River Basalt Group and the basalt of Weiser is unknown. An older flow of the basalt of Cuddy Mountain underlies a Grande Ronde Basalt flow and, additionally, a young flow may overlie a Grande Ronde Basalt flow (Fitzgerald, 1982). These observations suggest that the basalt of Cuddy Mountain spanned at least the time of the Grande Ronde Basalt (Fitzgerald, 1982) and its uniqueness may be related to early faulting of the Cuddy Mountain uplift, which may have caused an isolated vent to form. Alternatively, Hooper and Swanson (1990) included the basalt of Cuddy Mountain in the basalt of Weiser and correlated both with the Strawberry Volcanics of Oregon.

Between eruptions, soils were developed and reworked ash and sediment were deposited as interbeds and in local basins caused by structural disturbances. These thin, discontinuous deposits are part of the Payette Formation (Tp) and are correlative with the Latah Formation of the Clearwater embayment (the southern tip of which extends into the northern edge of pl. 1). The lower part of the Payette Formation is interbedded with the Imnaha and Grande Ronde Basalts and the upper part of the Payette Formation is interbedded with the basalt of Weiser (Fitzgerald, 1982).

Thick arkosic sediments of the Idaho Group (QTi) were deposited along the southern margin of the Weiser embayment and in fault-bounded Long Valley, south of McCall and Cascade (eastern pl. 1; Kirkham, 1931). The composition of this debris indicates source areas in granitic rocks of the Idaho batholith to the east. The location of the deposits shows that modern drainages were established at the time of deposition (Schmidt and Mackin, 1970; Fitzgerald, 1982).

During gold placer operations, Tertiary shale, sandstone, and lignite deposits were discovered under Quaternary deposits from lower Grouse Creek into Secesh Meadows, and in Warren Creek above and below the town of Warren (central pl. 2). The deposits are tilted as much as $25^{\circ}$ and have faulted margins (Capps, 1940). These are not shown on the map because of their minor exposures in abandoned placers. 


\section{Quaternary Deposits}

Quaternary deposits (Qu) in the forest include sandy and gravelly alluvium, talus, landslide debris, moraines, and glacial outwash. These deposits are closely linked to the Quaternary structural history and are critical in understanding the formation of the important placer deposits in the forest.

Block faulting controlled formation and filling of basins from the Pleistocene to Holocene (Schmidt and Mackin, 1970). At least 2,300 $\mathrm{m}$ of valley-fill sediments are found in Long Valley between the West Mountains escarpment on the Long Valley fault and the town of Donnelly (southeastern pl. 1; Kinoshita, 1962; Schmidt and Mackin, 1970). These are composite deposits that began to form in the late Tertiary because of drainage disruption during basalt eruption (see previous discussion on Idaho Group, QTi) but resulted mostly from glacial activity during the Pleistocene.

Four periods of alpine glaciation have been identified in the forest. The oldest glacial deposits, which include fluvial, lacustrine, and morainal remnants, are considered early Pleistocene (pre-Bull Lake) but the age is not well constrained (Schmidt and Mackin, 1970). A 20-km-long glacier descended from Marshall Mountain to the mouth of Lake Creek, a 17-km-long glacier descended from War Eagle Mountain to Secesh Meadows (northwestern pl. 2; Capps, 1940), and the longest glacier descended more than $34 \mathrm{~km}$ down the North Fork of the Payette River into Long Valley south of McCall (west-central pl. 2 to east-central pl. 1; Schmidt and Mackin, 1970). Lacustrine deposits and associated minor lignite deposits (Capps, 1940), which are related to this glaciation, are tilted as much as $25^{\circ}$ by continued normal fault activity (Schmidt and Mackin, 1970). Morainal deposits form subdued dissected ridges containing deeply weathered boulders. Conspicuous quartzite-pebble gravels along valley walls are interpreted as a refractory element of once larger lateral moraine deposits (Capps, 1940; Schmidt and Mackin, 1970). These quartz-cobble gravels are thought to have been formed by total disintegration of granitic materials that must have originally formed the bulk of the lateral moraine deposits. Lateral moraines of this age have been identified on the basis of these gravels (Capps, 1940).

Bull Lake moraines are found upstream from pre-Bull Lake glacial deposits and are well displayed in Long Valley south of McCall (eastern pl. 1). These moraines have been noticeably subdued by erosion into smooth hummocky topography. Typical of Bull Lake deposits in general, a large percentage of the granitic pebbles to boulders in the morainal deposits disintegrate easily when struck by a hammer. Most depositional features of the Bull Lake outwash in Long Valley have been eroded or covered by younger activity (Schmidt and Mackin, 1970). Evidence of probable Bull Lake-equivalent outwash is also described in Secesh Meadows (Capps, 1940).

Inactive high gravel terraces are found in and upstream from Secesh Meadows (west-central pl. 2; Capps, 1940) and along some streams such as the South Fork of the Salmon River (central pl. 2). These are at least $10 \mathrm{~m}$ above present stream levels and are probably remains of outwash from the two earlier glaciations (Capps, 1940). Gravel deposits stranded on the west sides of the Secesh River (central pl. 2) and the West Fork of the Rapid River (north-central pl. 1) drainages are outwash derived from terminal moraines coalescing at the mouth of tributary drainages. The upper part of Big Creek, near the settlements of Big Creek and Edwardsburg, to the mouth of Smith Creek (central pl. 2) is underlain by glacial outwash probably related to both early glaciations. The hogback in the middle of the valley is either a roche moutonnée or a remnant caused by crowding of the outwash stream against the east wall of the valley where it cut into bedrock instead of following the main part of the valley.

In most cases, Pinedale glaciers did not extend as far downstream as earlier glaciers. Except for the long valley glacier that reached down the North Fork of the Payette River (west-central pl. 2), they mostly stayed in tributary valleys (Capps, 1940). The Pinedale moraines are rough and little modified by erosion. A large percentage of the pebbles to boulders in the moraines are fresh. Much of the depositional surface of the Pinedale outwash is preserved and is prominent in aerial photographs of Long Valley south of McCall (see Schmidt and Mackin, 1970; eastern pl. 1). This outwash fills the valley that was cut into earlier outwash during the intervening interglacial period (Schmidt and Mackin, 1970).

Glacial deposits are important hosts to detrital placer gold. The quartz-cobble deposits found along valley walls that are the remains of pre-Bull Lake lateral moraine and outwash deposits were worked early in the history of placer mining particularly in the Secesh River and Warren Creek drainages (eastern and central pl. 2, respectively; Capps, 1940) and in French Creek (west-central edge pl. 1). These deposits formed as a result of both glacial transport of older gold-bearing stream gravels and later weathering that disintegrated granitic boulders of the moraines (particularly lateral moraines), allowing much of the debris to be washed away and thus concentrating the gold in the refractory materials (particularly along valley walls). Pre-Bull Lake and Bull Lake glacial outwash terrace gravels were placered along the South Fork of the Salmon River (central pl. 2).

Cirque glaciers formed in north- and northeast-oriented valleys at higher elevations throughout the forest. These probably formed as a composite of Pleistocene and Holocene glaciers; some moraines, present high in these cirques, are extremely fresh and unvegetated. These are found particularly in the Seven Devils Mountains (northern pl. 1) but also on Cuddy Mountain (west-central pl. 1) and in the West Mountains to Council Mountain area (east-central pl. 1). They are also prevalent in the peaks along the east side of McCall (locally referred to as the McCall alps), near Stibnite, in the Profile Gap to Big Creek area, and in the River-of-No-Return Wilderness (central to eastern pl. 2).

Most streams contain minor active alluvial sediments, which are mostly not shown on the map. Some placer mines have been located in modern stream sediments. 
Large block-field and talus deposits are particularly common in the high granitic peaks east of McCall. The granodiorite/tonalite rocks there are not as prone to chemical breakdown as the granites to the east, and the environment is conducive to freeze-thaw action and formation of blocks.

Landslide deposits in the forest are most common in ground underlain by volcanic rocks of the Blue Mountains island arc, the Columbia River Basalt Group, and the Thunder Mountain caldera. This is primarily because of widespread alteration and abundance of clay minerals.

\section{Metamorphic History}

Areas of the forest east and west of the Salmon River suture had different metamorphic histories before accretion of the island-arc rocks to Laurentia in the Late Cretaceous. The history of both sides includes several early metamorphic events resulting in both regional and local metamorphic changes. However, because late Early Cretaceous (pre-130 Ma) assemblages near the suture are so dominant, it can be difficult to identify earlier metamorphic fabrics.

\section{Proterozoic Metamorphism of Laurentian Rocks}

Mesoproterozoic sedimentary rocks of Laurentia underwent metamorphism ranging from low to high grade during the Mesoproterozoic. The existence and age of this early metamorphic event are documented by observations from the east side of the forest and the adjacent Salmon National Forest. In the Salmon National Forest, Mesoproterozoic sedimentary inclusions in 1,370-Ma granitic porphyritic granite/augen gneiss (Evans, 1981; Evans and Zartman, 1990) were metamorphosed and cleaved prior to being intruded, and greenschist facies metamorphic fabric in the Mesoproterozoic sedimentary rocks is overprinted by a metamorphic aureole related to the granites (Evans, 1981). Additional evidence comes from high-grade gneisses and migmatites along the Salmon River, which formed during this Mesoproterozoic metamorphic event in association with porphyritic granite/ augen gneiss (Yagn). Migmatite leucosomes were dated at 1,370 Ma (Doughty and Chamberlain, 1996). Migmatites along the lower Middle Fork of the Salmon River are also closely related to porphyritic granite/augen gneiss (fig. B9). It is not known how much of the lower grade metamorphism seen in east-central parts of the forest may have formed during this early event.

Neoproterozoic rift-related intrusions may have resulted in minor contact metamorphism but mineral assemblages related to this event have not been identified in this study.

\section{Triassic Metamorphism of Island-Arc Basement}

The oldest metamorphism represented in island-arc rocks in the forest is in the amphibolite facies rocks of the Oxbow-Cuprum shear zone (Vallier, 1967), which form the basement to the Wallowa terrane (west-central edge pl. 1).
This syndeformational metamorphism is dated between 233 and $213 \mathrm{Ma}$ (Ave Lallemant and others, 1980; Walker, 1986). The metamorphism and deformation in the Permian and older rocks and the hiatus in Wallowa terrane volcanism are related to Late Triassic left-lateral intra-arc tectonism (Ave Lallemant, 1995; Vallier, 1995).

\section{Late Jurassic to Early Cretaceous Metamorphism of Island-Arc Rocks}

Lower greenschist facies rocks of the Blue Mountains island arc along the Snake River, at Cuddy Mountain, and in the Hitt Mountains are the lowest grade metamorphic rocks west of the Salmon River suture zone in the forest. Metamorphism of these rocks is related to early phases of deformation (White, 1968, 1973). The lower greenschist facies metamorphic event has not been dated but, in the Seven Devils Mountains, it predated local contact metamorphic overprinting related to emplacement of younger plutons (preliminary date of about $137 \mathrm{Ma}$; Armstrong and others, 1977). The lower greenschist facies metamorphism in western island-arc rocks has been related to intra-arc tectonism that resulted in amalgamation of the terranes (Vallier, 1995), first thought to be during the Late Triassic and Early Jurassic (Ave Lallemant and others, 1985) but more recently recognized as a Late Jurassic to earliest Cretaceous event (Walker, 1989; Ave Lallemant, 1995; Vallier, 1995). Serpentinized melange containing fragments of the Baker terrane ( $\left.\mathrm{MzP}_{z} \mathrm{~b}\right)$ and the Weatherby Formation (Jws) of the Izee terrane marks the Cuddy Mountain fault zone (west-central pl. 1), along which the Baker and Izee terranes are juxtaposed during this event (Mann, 1989, 1991; Vallier, 1995). In the high-grade metamorphosed Riggins Group gneisses (JPmv) of the metamorphosed volcanic/plutonic complex, garnet cores have been dated as pre-144 Ma (Selverstone and others, 1992; Getty and others, 1993) and thus preserve metamorphism of latest Jurassic age but of unknown origin, perhaps related to nearby 158- to 160-Ma magmatism. Direct evidence of relationships was probably destroyed by intense overprint of Cretaceous tectonism.

\section{Cretaceous Overprinting Metamorphism}

The predominant metamorphic mineral assemblages and oriented fabrics, prevalent in the central part of the forest, formed during the Cretaceous suturing of the oceanic rocks to Laurentia and overprinted and destroyed most earlier metamorphic effects. This metamorphism is manifested in metamorphic grade that increases structurally upward and toward the suture from both the east and west. This is a regional inverted metamorphic gradient caused by structural stacking of deeper, hotter rocks over more shallow, cooler rocks (Lund, 1984, 1988a; Lund and Snee, 1988). The metamorphic grade related to this event ranges from greenschist to upper amphibolite facies. East of the suture, much of the 
metamorphic rock now exposed was at depths in the crust such that it was not uplifted and cooled until after emplacement of the Late Cretaceous Idaho batholith (Lund and others, 1986). Thus, attempts at dating metamorphic minerals from Laurentian rocks have not resulted in good information about the timing of this metamorphic event. Dates on the metamorphism from west of the suture, where rocks were not as deeply buried or were more expeditiously uplifted and cooled, indicate prolonged Cretaceous metamorphic events having multiple pulses of thrust (and reverse) faulting and cooling. The most intense metamorphic events ranged from 120 to $110 \mathrm{Ma}$ (Lund and Snee, 1988), perhaps beginning by $128 \mathrm{Ma}$ (Getty and others, 1993). Because the country rocks were already hot from compressional tectonism and thrust fault burial, contact metamorphic effects related to Idaho batholith plutons are only found locally in the lowest grade country rocks. Some contact metamorphic mineral growth occurred in rocks not much affected by nearby thrust faults or by deep burial. Narrow hydrothermal alteration zones are present around polymetallic vein systems affecting both metamorphic and igneous rocks.

\section{Structure}

As with metamorphism, rocks east and west of the Salmon River suture underwent separate early deformational histories. During Cretaceous accretion of the island-arc terranes to Laurentia, rocks on both sides of the suture underwent complex deformation. Kinematically related Cretaceous and younger deformation affected both sides together.

\section{Proterozoic Deformation in Laurentian Rocks}

Strong foliation and outcrop-scale folding of biotite gneiss (Ygn) exposed in and near the lower Middle Fork of the Salmon River (eastern pl. 2) were thought to be related to deformation and melting associated with formation of the Late Cretaceous Idaho batholith (Hamilton, in Cater and others, 1973). However, this study shows that the foliated, folded, and migmatized biotite gneiss (Ygn) is cut by Mesoproterozoic porphyritic granite/augen gneiss (Yagn; fig. B8), a relationship documented in the Salmon National Forest (25 km to the east) by geologic data (Evans, 1981; Evans and Zartman, 1990) and dating (Doughty and Chamberlain, 1996). Therefore the deformation preceded intrusion of porphyritic granite/augen gneiss (Yagn; fig. B8). Preliminary evidence further suggests that the deformation was part of a Mesoproterozoic orogenic event that led to melting of the biotite gneiss and was related to formation of porphyritic granite/augen gneiss (Yagn), as seen in the high-grade gneisses in the Middle Fork of the Salmon River canyon (fig. B9; Lund, Evans, and Esparza, 1983). The foliation of country rock and the partial melt related to formation of the porphyritic granite/augen gneiss are the only known evidence of a pre-Cretaceous (Mesoproterozoic) compressional deformation in the forest. Detailed study of style, sequence, orientation, and timing of deformations has not been attempted, so kinematic interpretation of this proposed event awaits future study.

Neoproterozoic volcanic rocks and syenite-diorite plutons (Zsd) formed as the result of Neoproterozoic rift-related normal faulting. No specific faults of this age are presently recognized in the forest. However, the general west-northwest trend of Neoproterozoic strata across the forest and a parallel large aeromagnetic anomaly (McCafferty, 1992; Kleinkopf, 1998) are herein interpreted to relate to a Neoproterozoic rift zone. The west-northwest orientation of Neoproterozoic plutons is thought to be directly related to Neoproterozoic normal fault control.

\section{Triassic Deformation in the Wallowa Terrane}

The Oxbow-Cuprum shear zone (Vallier, 1967, 1977, 1995) is a foliated and mylonitized zone in mafic gneisses of Wallowa terrane basement, Permian volcanic rocks, and mafic plutons that extends northeast from near The Oxbow on the Snake River into the southern Seven Devil Mountains (Cook, 1954; Cannon and others, in Hamilton, 1963; White, 1973; Gualtieri and Simmons, 1978). Based on U-Pb zircon dates on deformed plutons intrusive into the gneisses, the minimum age for the complex is about $249 \mathrm{Ma}$ (Walker, 1989). The elongation and deformation of the plutons in this zone (western to north-central pl. 1) suggest that the zone was already an important structure by Late Permian time and is probably related to the volcanic hiatus between Early Permian and Middle Triassic volcanic units of the Seven Devils Group.

Based on ${ }^{40} \mathrm{Ar} /{ }^{39} \mathrm{Ar}$ dates between 224 and $217 \mathrm{Ma}$ on metamorphic hornblende and biotite, which have been related to deformation in the zone (Ave Lallemant and others, 1980), a Late Triassic left-lateral intra-arc deformation event has been interpreted (Ave Lallemant and others, 1985). Blueschist formed in the Baker terrane in central Oregon at about the same time (Hotz and others, 1977). The 217- to 224-Ma deformation events in the Oxbow-Cuprum shear zone of the Wallowa terrane and in the Baker terrane were concurrent with formation of widespread carbonate reefs in the Martin Bridge Formation of the Wallowa terrane and onset of volcanism and plutonism in the Olds Ferry terrane. This tectonic event in the Wallowa terrane probably related to an intra-arc event that signalled a major change of tectonic facing in the Blue Mountains island arc and resulted in waning of volcanism that built the Wallowa terrane and beginning of volcanism to build the Olds Ferry terrane. 


\section{Late Middle Jurassic to Early Cretaceous(?) Deformation in Island-Arc Rocks}

Late Middle Jurassic to Early Cretaceous(?) structural features and plutonic rocks are probably related to amalgamation of the island-arc terranes into their present relative geometry (Walker, 1986). Structures are preserved as northwest-dipping (southeast-vergent) reverse and thrust faults in southwestern parts of the forest (fig. A3; pl. 1). The Wallowa terrane was thrust southeastward over the Baker terrane along the Wildhorse fault (Mann, 1989, 1991), which trends northeast generally along the Wildhorse River (west-central pl. 1). The Baker terrane was faulted over the Izee terrane along the Jurassic southeast-vergent Connor Creek thrust fault (Brooks, 1979), which can be traced northeastward along the west side of Cuddy Mountain (western pl. 1). In the forest, the Connor Creek thrust fault has subsequently been tilted to steeply dipping, and has undergone significant late Cenozoic reactivation as a normal fault (called the Cuddy Mountain fault by Mann, 1989, 1991). In the Cuddy and Hitt Mountains and in Oregon, the Izee terrane, although partially derived from the Olds Ferry terrane, also is thrust eastward over the Olds Ferry terrane (Brooks, 1979; Mann, 1989) on a series of northwest-dipping reverse faults. These faults have been referred to in part as the Bayhorse thrust (Livingston, 1932), and traced across the Hitt Mountains and the Middle Brownlee Creek to the Crooked River (Mann, 1989).

The amalgamation-related, southeast-directed reverse faults previously were considered a Triassic to Jurassic event (Ave Lallemant and others, 1980, 1985) or a Late Jurassic event (Ave Lallement, 1995; Vallier, 1995). This has been more closely defined by the presence of distinct Upper Triassic and Jurassic volcanic and volcanogenic sedimentary rocks in the Olds Ferry, Izee, and Wallowa terranes (deformed by the southeast-vergent reverse faulting) and by dating of Late Jurassic to Early Cretaceous(?) plutons that intruded the structures. Thus, age of amalgamation is limited to late Middle Jurassic to earliest Cretaceous (pre-124 Ma; Walker, 1986, 1989). The complex relationships, which are indicated by interpretations that the Izee terrane was formed partially atop the Olds Ferry terrane from debris derived from both the Olds Ferry and Baker terranes, suggest that instead of an amalgamation of separately formed terranes, a complex history of intraarc deformation and changes of subduction direction is probably the case (as implied by Vallier, 1995). During the Middle Jurassic, the Blue Mountains island arc changed character and approached Laurentia as evidenced by renewed volcanism and the deposition of fluvial rocks having fossils with some North American affinity on the Wallowa terrane (White and others, 1992). Late Middle Jurassic plutons (KJtf) dated at about $158 \mathrm{Ma}$ in unit KJPvp and the same age Wallowa and Bald Mountain batholiths in Wallowa terrane of Oregon (Armstrong and others, 1977) and in the metamorphosed volcanic/plutonic complex (this study) are the magmatic effects of this event.

\section{Late Jurassic to Early Cretaceous Deformation in Island-Arc Rocks}

Several regional-scale, west-directed thrust faults (northwest pl. 1) are interpreted to be Late Jurassic to Early Cretaceous from contradictory information. The westernmost juxtaposes Permian Hunsaker Creek Formation east of (and above) Triassic rocks probably along a west-directed thrust fault that has undergone later down-to-the-east normal faulting (interpreted from Cannon and others, in Hamilton, 1963; Vallier, 1967, 1977; Morganti, 1972; G.C. Simmons, USGS, unpub. data, 1980). Another thrust system, which lies structurally below and west of the Rapid River thrust fault, probably cuts previously folded rocks in a duplex structure (C.M. Onasch, written commun., 2003) and resulted in deformation and imbrication of Martin Bridge and Doyle Creek Formations throughout much of the north-central part of plate 1 (interpreted from Onasch, 1977; Detra, 1980; G.C. Simmons, USGS, unpub. data, 1980; Aliberti, 1988; Gray, 2001). The western side of the pluton in Rapid River (KJqd) intruded one of these thrust faults between the Martin Bridge and Doyle Creek Formations (Gualtieri and Simmons, 1978; G.C. Simmons, USGS, unpub. data, 1980; Gray, 2001). A similar structure or a continuation of this structure can be interpreted from mapping and descriptions in the southern Seven Devils Mountains (Cook, 1954; White, 1968) where the Deep Creek and Echols Mountain plutons (KJqd) preferentially intruded a zone of strongly deformed carbonate rocks overlying volcaniclastic rocks. That the pluton intruded as a possible sheet form (Cook, 1954) is corroborated by map expression. Although foliation, cataclasis, and metamorphism in roof pendants and wall rocks of the Deep Creek and Echols Mountain plutons were previously attributed to intrusive pressure, and foliation in the plutons was attributed to magma flow (White, 1968, 1973), these may relate to syndeformational emplacement during synclinal folding (Cook, 1954) and (or) thrust faulting. Thus, emplacement conditions and geometries for these plutons are like those for the pluton in Rapid River, along structural trend to the north. The approximate 137-Ma age of the Deep Creek pluton (Armstrong and others, 1977) and the approximate 145-Ma age for the pluton in Rapid River (Snee and others, 1995), being K-Ar system ages, give an approximate minimum age for the west-directed structures. Although the ages for these plutons and the structures they cut are in the time bracket for amalgamation events (Walker, 1986), this structure fits geometrically as an early outboard record for the onset of accretion. Because it is as much as $15 \mathrm{Ma}$ earlier than related structures, the latest Jurassic to earliest Cretaceous(?) magmatism and west-directed structures remain enigmatic.

\section{Cretaceous Deformation}

The predominant ductile structures in the forest are complex overprinting features that have been kinematically linked to right-lateral transpressive accretion of the island-arc 
rocks to Laurentia in the Cretaceous (Lund, 1984), spanning about $40 \mathrm{Ma}$ (Lund and Snee, 1988; Selverstone and others, 1992; Manduca and others, 1993; Snee and others, 1995). Pervasive deformational fabrics are strongest where diverse country rocks and pre- and syn-deformation plutons on the leading edges of both the oceanic terranes and Laurentia are strongly deformed through a complex sequence of events (Lund and Snee, 1988). High-angle reverse faults brought rocks near the suture up from deeper crustal levels and over the less deformed rocks to both the east and west. Deformation fabrics are progressively more discrete and weaker away from the suture. Farther away from the suture, the country rocks are foliated and original sedimentary layering is commonly preserved. In areas of the forest farthest from the suture, some of the country rocks only exhibit cleavage rather than schistosity and original features of the rocks are well preserved. Astride the suture, country rocks and Early Cretaceous plutons are strongly foliated, folded, and lineated together. A number of studies have concentrated on geochemistry and deformation in these plutonic rocks where discrete mylonite zones in the Salmon River suture complex are referred to as the Western Idaho shear zone.

\section{Structures West of the Salmon River Suture}

In the northwestern part of the forest (northern pl. 1), Cretaceous structures west of the Salmon River suture are west-directed reverse and thrust faults and associated folds. The west-directed Cretaceous reverse and thrust faults form an inverted metamorphic sequence, wherein higher grade rocks are faulted westward over lower grade rocks. In the eastern part of the belt, the intense deformation obliterated Late Triassic shear zones and late Middle Jurassic southeast-directed island-arc amalgamation reverse faults. In the west-central part of plate 1, cover by the Columbia River Basalt Group obscures the interplay among the west-directed Cretaceous structures and metamorphism (related to island-arc accretion), east-directed Triassic shear zones (intra-arc deformation), and late Middle Jurassic to Early Cretaceous(?) reverse and thrust faults (formed during arc amalgamation).

The most throughgoing, west-directed thrust fault thought to be part of the Salmon River suture event is a southern continuation of the Rapid River thrust fault, named near Riggins, Idaho, north of the forest boundary (Hamilton, 1963) and mapped into the forest (White, 1968; Onasch, 1977; Gualtieri and Simmons, 1978; Aliberti, 1988). The Rapid River thrust fault is a regionally recognizable structure that marks an important juxtaposition of rocks of different metamorphic grades. Along the Rapid River thrust fault, upper greenschist facies muscovite-chlorite metavolcanic schist of the Lightning Creek Schist (JPrl) and graphitic biotite schist of the Squaw Creek Schist (JPrs), which are continuous with metamorphosed island-arc rocks to the north (the Riggins Group of Hamilton, 1963), are thrust westward over greenstone volcanic and sedimentary rocks and minor lower greenschist facies rocks of the Wallowa terrane (pl. 1).
Based on the location of footwall versus hanging-wall rocks, a further southward continuation of this fault is probably covered by the Columbia River Basalt Group along or near the eastern flank of Cuddy Mountain (central pl. 1). The Rapid River thrust fault has essentially been viewed as a terrane boundary (Brooks and Vallier, 1978; Hamilton, 1978; Vallier, 1995) although the high-grade rocks east of the fault have been correlated with different terranes by different authors (see discussion in Lund, 1988). In the absence of conclusive information on protolith age or correlation of the high-grade island-arc rocks, and after consideration of the overall structural patterns, it is simplest to interpret the Rapid River thrust fault as only one of a series of similar west-directed faults west of the suture and being related to the suturing process (Lund, 1984, 1988a, 1995).

The Rapid River thrust fault is a complex zone of thrust faulting. In the footwall along the Rapid River and in the western Seven Devils Mountains (northern pl. 1), slivers of Martin Bridge Formation ( $\mathrm{km}$ ) and greenschist facies Lightning Creek and Squaw Creek Schist (JPrl and JPrs) are associated with steep shear fabrics (Onasch, 1977; Detra, 1980; G.C. Simmons, USGS, unpub. data, 1980; Aliberti, 1988; Gray, 2001). Additional normal fault reactivation, shown by chloritic breccia in plutonic rocks, occurred along much of the Rapid River drainage.

Structurally above the Rapid River thrust fault, another major west-directed moderately steep reverse fault cuts the north and west sides of Pollock Mountain and continues northeastward to cross the Salmon River (northern pl. 1). This reverse fault brings upper amphibolite facies metamorphic rocks (JPam) westward over the greenschist facies rocks (Aliberti and Manduca, 1988; Aliberti, 1988; Selverstone and others, 1992; this study). The amphibolite facies rocks are complexly deformed (fig. B7) beginning at about $128 \mathrm{Ma}$ (Selverstone and others, 1992; Getty and others, 1993). In the eastern extent of the unit, amphibolite facies rocks underwent intense shearing and lit-par-lit injection and cooled in thrust plate packages about 118 and $90 \mathrm{Ma}$ (Lund and Snee, 1988; Manduca, 1988; Manduca and others, 1993; Snee and others, 1995; K. Lund and D.M. Unruh, unpub. data, 2002).

Faults along the eastern and western margins of the heterogeneous orthogneiss complex of the Salmon River suture (Kgn and Kpgdm) are interpreted to be two steeply dipping divergent reverse faults (Aliberti, 1988; Selverstone and others, 1992; Manduca and others, 1993) and are discussed in more detail in the "Western Idaho Shear Zone" section. This geometry is similar to that described in the Nez Perce National Forest (north of fig. A3) where it is interpreted to represent structures bounding the youngest zones of deformation related to the Salmon River suture (Lund, 1984, 1988a, 1995; Lund and Snee, 1988; Lund and others, 1993). Both of these zones of reverse faulting underwent post-Miocene reactivation by normal faults with opposite sense of movement (as shown on eastern pl. 1). 


\section{Thrust Faulting and Folding East of the Salmon River Suture}

East of the Salmon River suture, there have been few structural studies and it is commonly assumed that no effects of suturing were recorded east of the suture (see, for example, Tikoff and others, 2001). However, recent mapping in Laurentian rocks east of the suture has documented similar but reversed patterns of east-directed higher grade rocks over lower, and of more deformed over lesser. The age of dynamothermal tectonism is pre-Idaho batholith (Lund, 1984; Lund and Snee, 1988; Lund and others, 1997), ending by 94-90 Ma (K. Lund, J.N. Aleinikoff, and D.M. Unruh, unpub. data, 2001-2002). The predominant structural fabric of the pre-Cretaceous rocks is their general northwest trend (central pl. 2). This trend is similar to geometries mapped in rocks better exposed to the east, where northwest-striking packages of Mesoproterozoic rocks, juxtaposed along northwest-trending thrust faults, are documented to be the regional structural pattern (Evans and Green, 2003). Through the middle of this belt, much of the exposed stratigraphy youngs to the southwest.

Based on stratigraphic interpretation from this study and map patterns projected into the forest from the Salmon National Forest to the east (Tysdal and others, 2003), there is an important break in trends in the eastern part of the Chamberlain Basin pluton (fig. A3; northern pl. 2). Mesoproterozoic rocks north of the Chamberlain Basin pluton are high-grade gneiss (Ygn) probably originally part of the Apple Creek Formation (Ylau), whereas Mesoproterozoic rocks south of the pluton are the Yellowjacket Formation and associated units (Yy and $Y h$ ). The major northwest-trending Cretaceous Iron Lake thrust fault in the western Salmon National Forest (Tysdal and others, 2000; Tysdal and others, 2003), which juxtaposes Yellowjacket Formation and Hoodoo Quartzite on the southwest against Lemhi Group units on the northeast, probably crosses the Middle Fork of the Salmon River in the area of Cradle Creek where low-grade calc-silicate-bearing siltite on the south (fig. A $8 A$ ) is juxtaposed against migmatite gneiss on the north (fig. A $8 B$ ). This fault zone probably continues northwest into the Chamberlain Basin pluton (fig. A3; northern pl. 2) where the marked northwest elongation of the pluton was probably controlled by the Iron Lake fault. The northwesterly aligned Neoproterozoic plutons are probably in the hanging wall where the thrust fault may have ramped up the Neoproterozoic to early Paleozoic rift margin normal faults. Major aeromagnetic anomalies (McCafferty, 1992; Kleinkopf, 1998; McCafferty and others, 1999), which lie parallel to the southern margins of the plutons, give further evidence of preexistence of an important compressional structure.

Comparison of the general stratigraphic sequence, from northeast to southwest across the Big Creek and Stibnite roof pendants (fig. A3), suggests a secondary structure that is part of this northwestward trend of units. Younging of units southwestward across the Big Creek roof pendant and northeastward across the Stibnite roof pendant suggests a large shallowly northwest plunging synclinal structure at least $25 \mathrm{~km}$ across. This inferred large syncline is much disrupted by Late Cretaceous intrusions and covered by Eocene volcanic rocks. The Thunder Mountain caldera lies entirely within this inferred syncline and is elongated in the axial direction. This superposition implies Cretaceous structural control on the location and geometry of the Thunder Mountain caldera.

To the northwest, the stratigraphic/structural packages change trend from northwest to north-northwest from the Marshall Mountain roof pendant to the Gospel Peaks roof pendant (fig. A3; northwestern pl. 2). The northerly structures near the Salmon River suture are probably influenced by proximity to that dominant structure. Because of the extent of Late Cretaceous intrusive rocks and present lack of data, the relative sequence of the northwesterly versus northerly trends is not determined. They may be: (1) a continuous reorientation of the regional patterns from northeast-directed thrust faulting in the eastern part of the forest to east-directed thrust faulting or (2) a younger set of east-directed structures that overprints the northeast-directed structures and thus mirrors the overprinted compressional geometry described west of the Salmon River suture.

Structures within individual roof pendants are part of larger regional trends but are complex at all scales. The basal contact of the Neoproterozoic rocks was probably an unconformity between the packages. However, a structural boundary is common between Mesoproterozoic and Neoproterozoic strata at the level of the Plummer Point Formation (Zpp). Layering and foliation of the two packages of rocks are regionally and locally discordant. High-grade gneisses and migmatitic rocks in lower parts of the Plummer Point Formation suggest that, in places, the base of the unit includes slivers of deeper seated rocks. The extreme thickness and relatively monotonous compositions of Mesoproterozoic units make interpreting structures in the Mesoproterozoic rocks very difficult, and little progress has been made in studying medium-scale structures in these rocks in the forest. Most of the identified structures are in the thinner, compositionally more diverse Neoproterozoic units. The complexity of map patterns shown on plate 2 indicates that the deformation was quite complex and that much more detailed structural study is required to determine kinematic history.

Outcrop patterns in the Marshall Mountain roof pendant (fig. A3) show that quartzite of the Square Mountain Formation (Zsm) overlies the other units along a low-angle thrust fault such that this unit forms a thrust sheet over the other units in the roof pendant. Minor folds in that thrust sheet are overturned to the northeast, indicating that the hanging wall moved northeastward. Units below the thrust fault are disrupted by additional faulting but comprehensive study of structures has not been addressed by the present work.

The structurally lowest recognized thrust fault in the Big Creek roof pendant (fig. A3), in the West Fork of Beaver Creek, North Fork of Smith Creek, and main Smith Creek drainages (north-central pl. 2), brings high-grade Mesoproterozoic calc-silicate and biotite gneiss (Ybc) eastward over lower to middle greenschist facies Mesoproterozoic biotite 

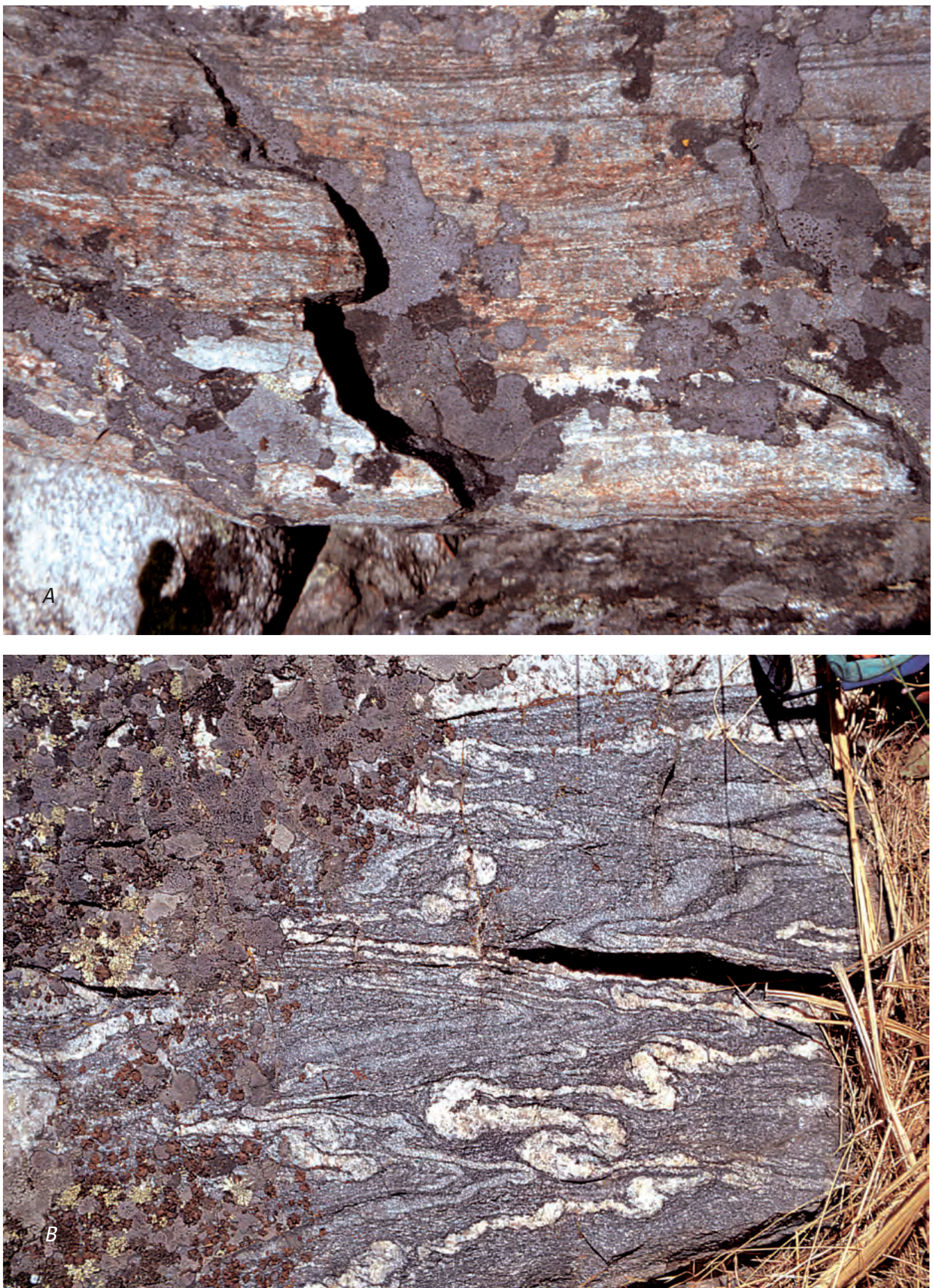

Figure A8. Contrasting metamorphic and deformation features across Cradle Creek fault on Middle Fork Salmon River. A, Greenschist facies calc-silicate-bearing siltite above mouth of Papoose Creek. View $20 \mathrm{~cm}$ wide. B, Migmatite gneiss, east side of Middle Fork Salmon River across from mouth of Cradle Creek. View $35 \mathrm{~cm}$ wide. 


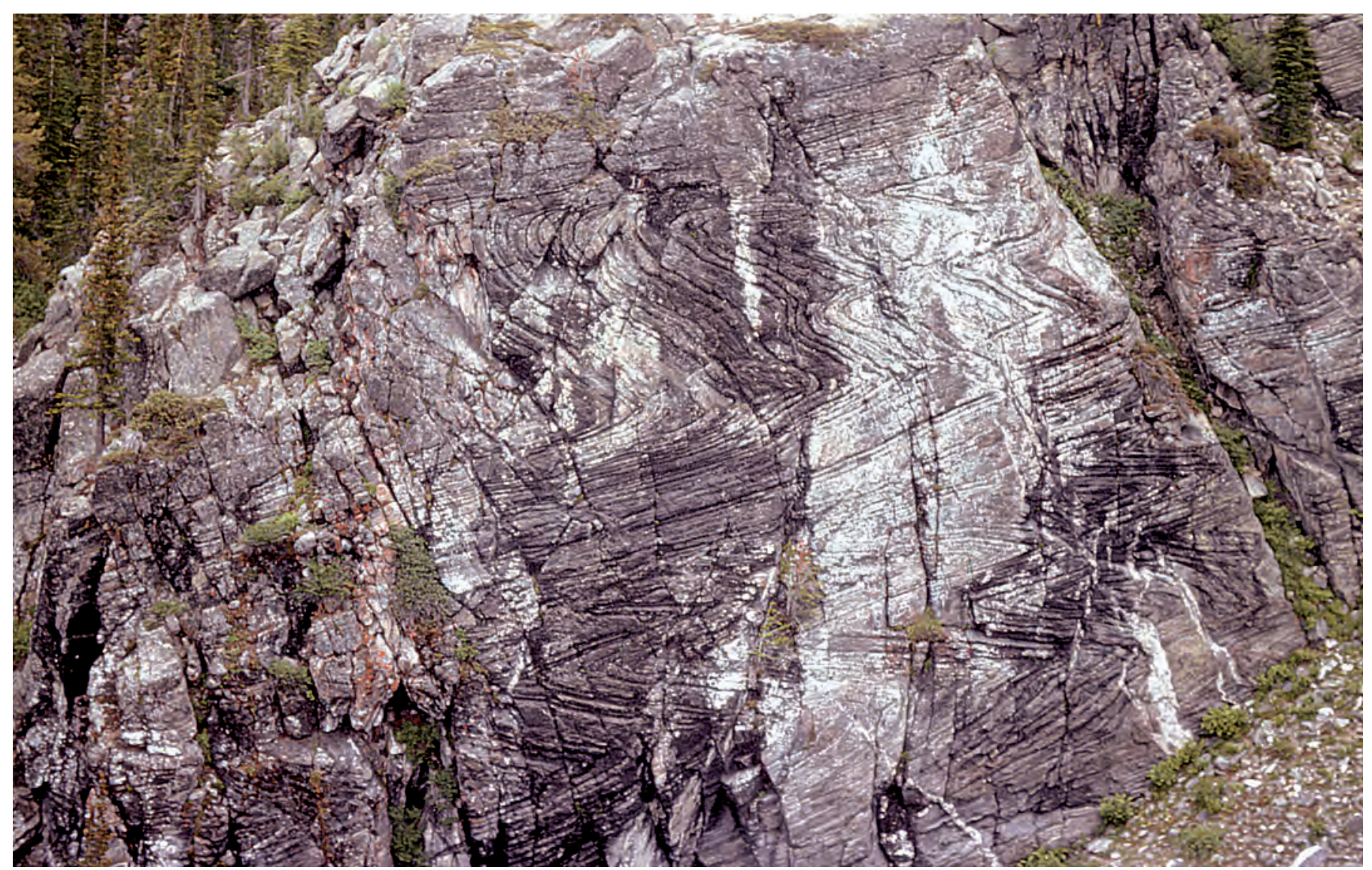

Figure A9. Asymmetric folds in calc-silicate gneiss of Missouri Ridge Formation (Zmr). View looking northeast on northwest side of Sugar Mountain (central pl. 2).

phyllite correlated with the upper part of the Apple Creek Formation (Ylau). This thrust fault is cut out progressively upward by thrust sheets that carry very different strata: (1) A steeply dipping overturned panel of rocks from the middle part of the Neoproterozoic section (Zam, Ze, Zms, and Zgc) lies in the middle of the stack. Limited exposure of this structure suggests interpretations of either an overturned thrust panel or a limb of a southwest-vergent overturned fold. (2) An upright section of the Neoproterozoic Square Mountain Formation (Zsm) is at the top of the stack but is exposed to the east as klippen of Square Mountain Formation lying directly on the lower plate of Mesoproterozoic rocks (Ylau and Ylg) without the intervening sheets that carry Neoproterozoic or higher grade Mesoproterozoic rocks. This complex geometry of cutting out of intervening thrust sheets suggests that the thrust faults were folded during progressive folding and thrust faulting, probably in a duplex structure. This western part of the Big Creek roof pendant is stranded between structures related to the western margin of the Thunder Mountain caldera directly to the east and the Johnson Creek-Profile Gap shear zone to the west. The amount of rotation, if any, of older structures by movement along either of these younger structures is not known.

Rocks in the central and northern Stibnite roof pendant, near Missouri Ridge and Profile Gap (central pl. 2), are predominantly a repetition of quartzite and carbonate units (Zlc and Zmr) from the upper part of the Neoproterozoic Windermere Supergroup. It is unknown if some of these rocks have been overturned and it is not presently possible to determine the relative amount to which folding or faulting has contributed to the repetition of these two units. Sense of transport from asymmetric folding seen in the Missouri Ridge Formation (Zmr) would indicate west-directed kinematics (fig. A9) but this cannot be confirmed directly because younging direction in these rocks was not established. The pattern of repetition is complicated in the middle part of the Stibnite roof pendant near Sugar Mountain (central pl. 2). There, diamictites of the Edwardsburg Formation (Ze) are preserved as a middle sheet; the older Neoproterozoic Anchor Meadow and Square Mountain Formations are in the highest sheet. These remnants of stacked thrust sheets are now perched high on the mountain as small klippen of older rocks structurally overlying younger. Under these isolated thrust sheets, there is a semblance of the repetition of the younger parts of the Windermere Supergroup like that seen elsewhere in the Stibnite roof pendant. In the southern part of the Stibnite roof pendant, a southwestward overturned syncline was suggested from previous mapping near the Fern mine (south-central pl. 2; White, 1941; Smitherman, 1985). Directly northeast, both upright and overturned 


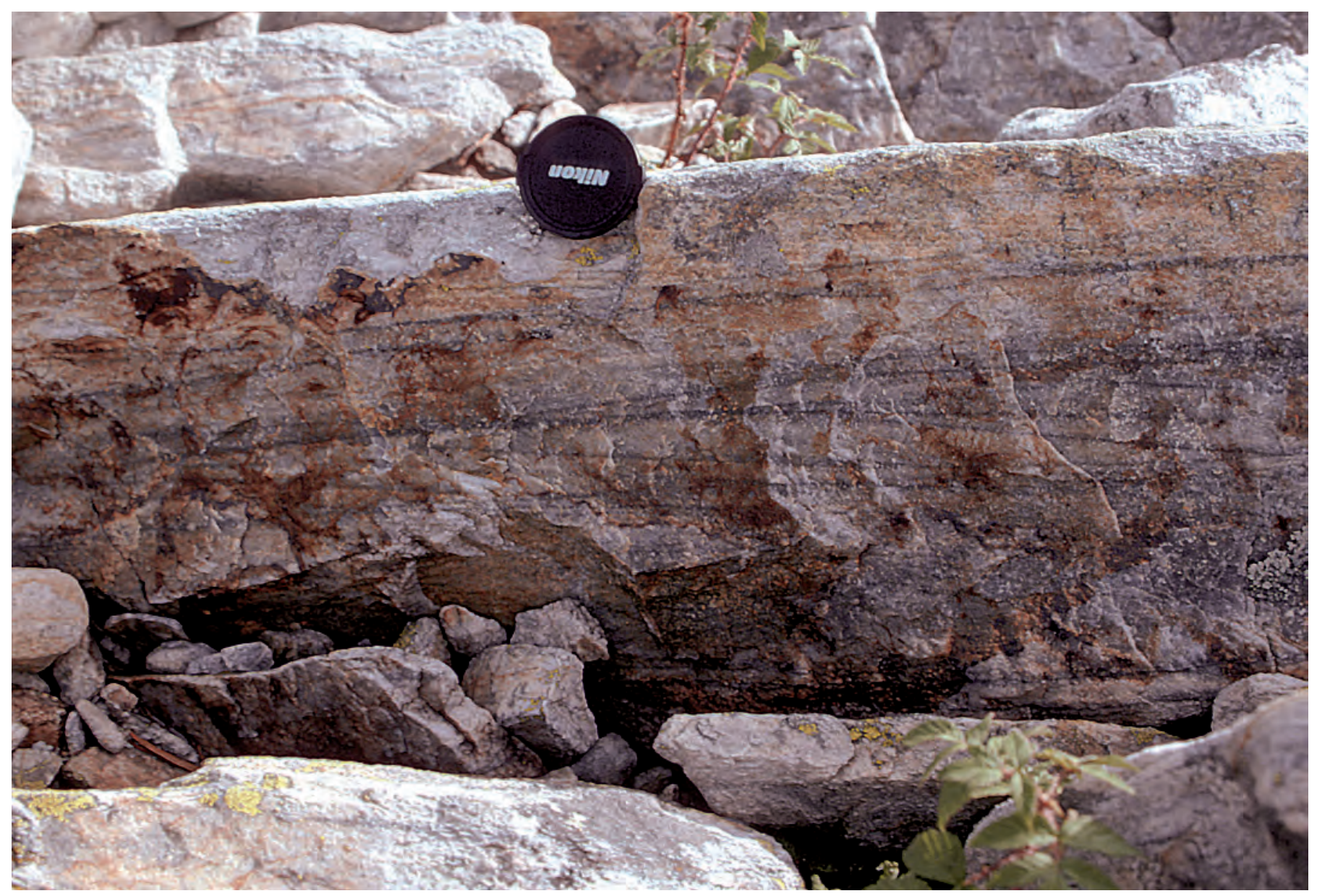

Figure A10. Overturned crossbedding in quartzite of Square Mountain Formation (Zsm). View looking north on north end of Cinnabar Peak ridge (central pl. 2). Lens cap $(7 \mathrm{~cm})$ for scale.

bedding (fig. A10) and discontinuous stratigraphic segments near Cinnabar Peak suggest several generations of thrust faults and folds. The order of units as presently understood might suggest a southwest-vergent anticline of a previously thrust faulted section, in turn suggesting duplex-style deformation.

There are very few known indications of transport direction along the faults or for vergence direction of the folds. In the Marshall Mountain roof pendant, small-scale folds indicate southwest-over-northeast vergence. The reverse fault in the northern part of the Big Creek roof pendant brings higher grade rocks over lower in a generally southwest-over-northeast sense of movement. Although the overall sense of compressional transport is thought to be northeastward, possible slivers of overturned folds west of the Thunder Mountain caldera and east of the Johnson Creek-Profile Gap shear zone suggest southwest vergence. Possible explanations for a local sense of southwest vergence between the Johnson Creek-Profile Gap shear zone and the western margin of the Thunder Mountain caldera include: (1) structures near the west side of the caldera may have been rotated by Tertiary normal faulting and (or) (2) Cretaceous faulting along the Johnson Creek-Profile Gap shear zone (see "Tertiary Deformation" section) may have developed local structures related to right-lateral transpressional kinematics along that shear zone, locally disrupting the overall southwest-over-northeast transport. The northwesterly trend of structures changes to a more northerly trend near the Salmon River suture, possibly as a re-orientation or as an overprinting of events. Further work on the compressional structures is clearly needed.

\section{Western Idaho Shear Zone}

A 20- to 25-km-wide zone along the Salmon River suture has been the focus of several studies (Manduca, 1988; Blake, 1991; Manduca and others, 1993; Tikoff and Manduca, 1997; McClelland and others, 2000). In this zone, part of the metamorphosed volcanic/plutonic complex, the heterogeneous orthogneiss complex, rocks of the older plutonic series, and screens of country rock are strongly foliated, lineated, and elongated parallel to the suture. Ductile fabrics are north-northeast-trending, vertical to steep east-dipping foliations, which are parallel to the suture, and near-vertical mineral and fold lineations (fig. A11). These indicate a large component of pure (nonrotational) shear and vertical movement (Lund, 1984; 
Lund and Snee, 1988; Manduca, 1988; Selverstone and others, 1992; Lund, 1995; Lund and others, 1997). Based on detailed fabric analysis, discrete mylonite zones within these strongly deformed rocks show a component of right-lateral motion (Tikoff and Manduca, 1997; McClelland and others, 2000) matching the direction of movement interpreted from regional structural studies (Lund, 1984; Lund and Snee, 1988). The planar fabrics and elongation of plutonic masses reflect emplacement and simultaneous deformation during the late stages of suturing. This is especially true for the gneissic units (Kpgdm, $\mathrm{Kgn}$, and KJPvp). Other plutons directly to the east, although elongate, are only foliated (Ktf and Kgdf) and the intensity of foliation decreases to the east away from the suture (Lund, 1984; Lund and others, 1997). This series of discrete shear and mylonite zones that cut the plutons emplaced into the Salmon River suture has been called the Western Idaho shear zone (Fleck and Criss, 1985; Strayer, 1988; Strayer and others, 1989) or locally the Little Goose Creek shear zone (Manduca, 1988; Manduca and others, 1993). The shear zone has been interpreted to be a separate, post-accretion event (Manduca, 1988; McClelland and others, 2000; Tikoff and others, 2001). However, regional interpretation of structure and timing suggests that features identified as part of the Western Idaho shear zone are areally restricted but kinematically related to earlier Cretaceous regional deformation. Accordingly, the Western Idaho shear zone is interpreted as a young stage of deformation related to transpressional accretion along the Salmon River suture (Lund, 1984; Lund and Snee, 1988).

Shearing along the Western Idaho shear zone continued until as late as $89 \mathrm{Ma}$, as older plutonic series plutons were deformed. Following emplacement of the older plutonic series, as much as $15 \mathrm{~km}$ of uplift on the continental side of the suture resulted in as much as $10 \mathrm{~km}$ of erosional stripping from 90 to $82 \mathrm{Ma}$. This uplift enhanced the cooling of metamorphic country rocks and the older plutonic series, and preceded emplacement of the younger plutonic series at shallower crustal depths (Lund and Snee, 1988; Manduca and others, 1993; K. Lund, J.N. Aleinikoff, and D.M. Unruh, unpub. data, 2001-2002).

\section{Geometry of Cretaceous Deformation}

Cretaceous deformational and metamorphic patterns indicate that intense ductile and brittle upwelling occurred along the axis of the Salmon River suture and that such deformation is similar to that documented in transpressional fault zones (Sylvester and Smith, 1976; Saleeby, 1981; Sylvester, 1988; Saint Blanquat and others, 1998). Based on the geometry of regional-scale structural and metamorphic patterns across the suture zone and on generally parallel ages of deformation on both sides, the Salmon River suture was interpreted to be an oblique right-lateral accretionary structure (Lund, 1984; Lund and Snee, 1988). This has been corroborated by detailed studies confined to the center of the zone and to the intrusive rocks that were deformed along related discrete structures (Manduca, 1988; Selverstone and others, 1992; Manduca and others, 1993; Tikoff and others, 2001). Although interpreted by some workers as separate accretion and post-accretion deformations (Manduca, 1988; Selverstone and others, 1992; Manduca and others, 1993; McClelland and others, 2000; Tikoff and others, 2001), both regional and suture-zone restricted deformations appear to be related to dextral transpression. The multiple phase, dynamothermal deformation features, which young toward the suture, are herein interpreted to be kinematically related to accretion.

\section{Shear Zones and Related Mineral Deposits East of the Salmon River Suture}

The Johnson Creek-Profile Gap shear zone (Lund and others, 1997) trends N. $10^{\circ}$ E. across the east-central part of the forest (fig. A3; central pl. 2). The shear zone is a 2-km-wide ductile structure in pre-Tertiary rocks, which also can be traced along discrete brittle fault segments in Eocene and pre-Tertiary rocks (Shenon and Ross, 1936; Gammons, 1988). Late Cretaceous granites (Kpg and Kg) and metasedimentary rocks caught in the shear zone have been sheared, mylonitized, and silicified (fig. A12). The metasedimentary rocks are dismembered and stretched parallel to the shear zone. Mylonitic fabrics superimposed on Late Cretaceous granites (fig. A12) indicate that the fault zone had a Late Cretaeous to Paleocene component of right-lateral movement. A component of pre-Eocene down-to-the-east offset is indicated by the presence of metasedimentary rocks caught in the shear zone and as roof pendants east of the zone whereas only more deeply emplaced plutonic rocks are exposed on the west side. Metamorphic trends are also disrupted across the zone; rocks to the west are higher grade than those to the east. The disruption of regional stratigraphic and metamorphic trends across this fault suggests it may have been a tear fault during Cretaceous compressional deformation, and right-lateral transpression may account for the possible southwest-directed folds on the east side of this fault zone. Near Stibnite, the Meadow Creek fault (White, 1941; Cookro and others, 1988) lies to the east of and parallels the Johnson Creek-Profile Gap shear zone (central pl. 2). Kinematics have not been determined for the Meadow Creek fault but deeper crustal rocks, exposed on the west side, indicate a component of down-to-the-east motion, and fold geometries suggest right-lateral motion (see following discussion). Thus, the large north-northeast-trending right-lateral shear zones east of the suture zone, the Johnson Creek-Profile Gap and Meadow Creek faults, may be genetically related to the Salmon River suture and right-lateral transpression may have continued to affect western Laurentia after intrusion of the Idaho batholith granites (Kpg and $\mathrm{Kg}$ ).

Precious-metal quartz-vein deposits of the Yellow Pine, Profile, and Edwardsburg mining districts (fig. A4) are localized within and along the east side of the Johnson Creek-Profile Gap shear zone. These vein systems trend north-northeast, parallel to the shear zone. The veins are abruptly discontinuous and quartz in the veins is strained (Gammons, 1988), indicating that the veins were emplaced during late-stage 


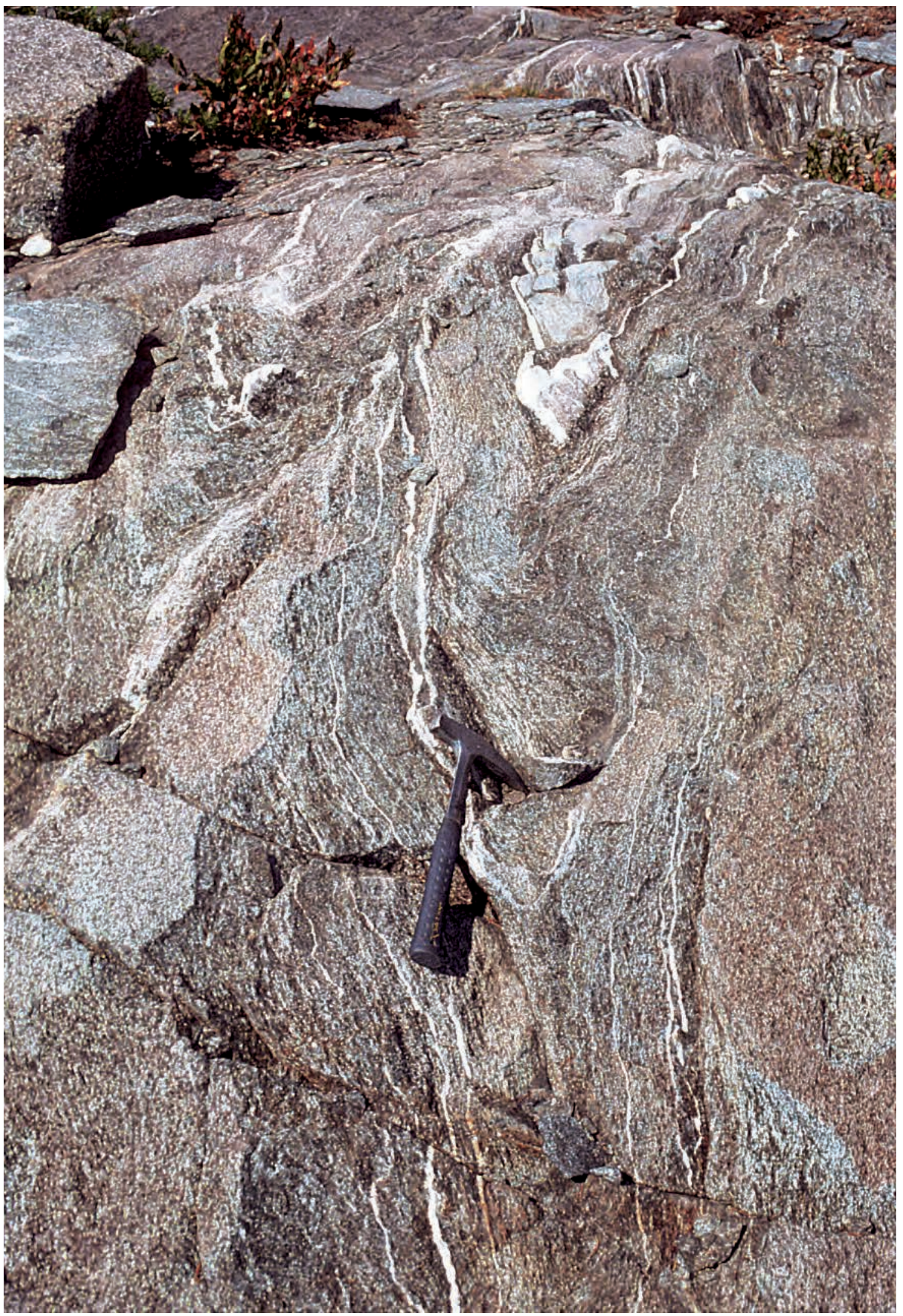

Figure A11. Deformation in metamorphosed volcanic/plutonic complex (KJPvp) in Salmon River suture zone. Pervasive, steep, north-northeast-striking foliation with steep fold and mineral lineations superimposed on several lithologies now structurally interleaved. Exposure west of Goose Lake (eastern pl. 1). View looking north. Hammer (handle $30 \mathrm{~cm}$ long) for scale. 


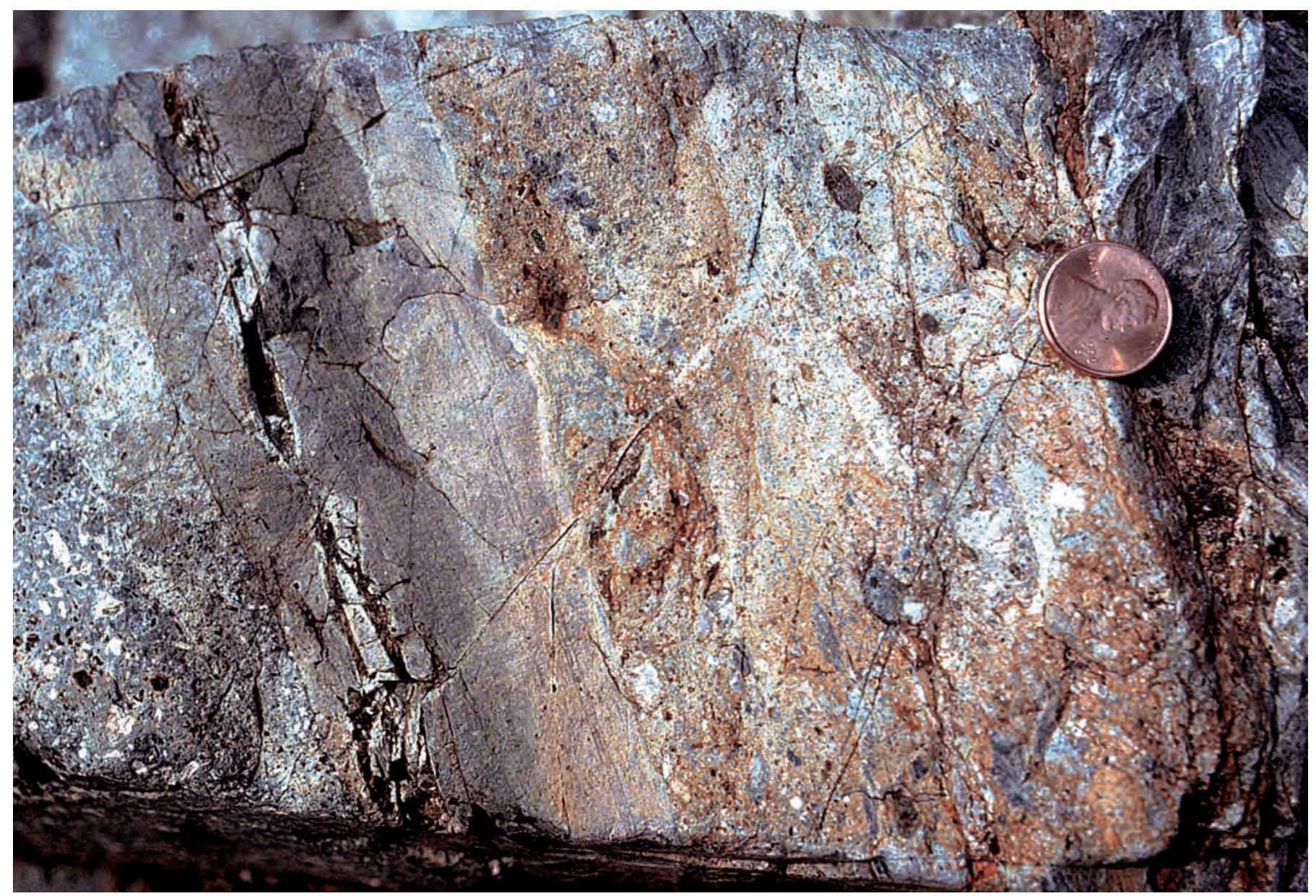

Figure A12. Shearing and mylonitization in Late Cretaceous granite $(\mathrm{Kg})$ from Johnson Creek-Profile Gap shear zone. Photograph of exposure $2 \mathrm{~km}$ west of Profile Gap (central pl. 2). Note undeformed Eocene rhyolite porphyry cutting shear zone on left side of photograph. Penny $(1.9 \mathrm{~cm})$ for scale.

ductile deformation and have been disrupted by Eocene and later brittle faulting. Dates on these deposits are complicated but are primarily Late Cretaceous (Gammons, 1988), about the same age as vein deposits with similar mineralogy in the Warren, Resort, and Marshall Lake mining districts (K. Lund, unpub. data, 1992). Disseminated gold and tungsten deposits near Stibnite (notably those at the West End, Meadow Creek, and Yellow Pine mines) are hosted at the intersection between the Meadow Creek shear zone and a northeast-trending strand (Cookro and others, 1988; Gammons, 1988). These deposits are also Late Cretaceous (Gammons, 1988).

A west-northwest-trending, low-angle mylonitic shear zone is mapped along the north side of the Neoproterozoic Rush Creek Point syenite-diorite complex (R.S. Lewis, Idaho Geological Survey, written commun., 1996) where it is in contact with the Mesoproterozoic Yellowjacket Formation and Hoodoo Quartzite (west-central pl. 2, fig. A3). The southeast end of the shear zone has not been mapped. The shear zone is cut off by Eocene volcanic and plutonic rocks on the northwest end. Measured lineations in the mylonite fabric dip shallowly east-southeast (R.S. Lewis, Idaho Geological Survey, written commun., 1996), indicating that this zone formed during east-southeast stretching. Based on crosscutting relationships, the age of this shear zone can only be constrained between the Neoproterozoic and Eocene. Unfortunately, this northern edge of the Rush Creek Point suite is the only place in the trend that is mapped in any detail so there is too little information to document the origin of the shearing or extent of the zone. The shear direction, as indicated by lineation in the mylonite fabrics on the north side of the Rush Creek pluton, parallels (1) the west-northwest trend of the Ramey Ridge, Acorn Butte, and Rush Creek Point syenite-diorite suites (fig. A3); (2) the Big Creek roof pendant of which the plutons are a part; (3) the northern edge of the Thunder Mountain caldera; (4) the southern margin of the Chamberlain Basin pluton (fig. A3); and (5) a prominent aeromagnetic gradient (McCafferty, 1992; McCafferty and others, 1999). These features suggest that this may be an important reactivated crustal feature that is at least as old as Neoproterozoic. The implication from the alignment of Neoproterozoic plutons, and possibly from the aeromagnetic data, is that the geology of the area was controlled by a structure related to Neoproterozoic rifting and later reactivated during Cretaceous compressional and Tertiary extensional deformations. 


\section{Tertiary Deformation}

\section{Structural Control of Dike Swarms}

North-northeast-trending fractures hosting Eocene dike swarms are prevalent throughout the south-central part of the forest in roof zones above concealed Eocene plutons. This orientation for extensional fractures filled with Eocene dikes is a widespread regional phenomenon in central Idaho, indicating regional east-southeast to west-northwest extension from about 50 to $45 \mathrm{Ma}$ (Rehn and Lund, 1981; Janecke, 1992; Vandenburg and Janecke, 1998). The Johnson Creek-Profile Gap shear zone (fig. A3) was reactivated during and after emplacement of Eocene magmas. Movement on the Johnson Creek-Profile Gap shear zone probably resulted in localization of the Profile Gap-Smith Creek dike swarm (Lund and others, 1997; central pl. 2) along the shear zone and emplacement of the Eocene Savage Point pluton (fig. A3) west of the shear zone. The Savage Point pluton is elongate in a west-southwest direction consistent with tension fracturing related to right-lateral movement along the Johnson Creek-Profile Gap shear zone in the Late Cretaceous to Eocene. The Rainbow Ridge dike swarm (Lund and others, 1997) is along a parallel southwest-northeast trend south of the Savage Point pluton and probably had the same origin.

\section{Ductile-Brittle Shear Zones}

In the Johnson Creek-Profile Gap shear zone, the Eocene dikes and small elongate stocks cut the mylonitic fabrics and are fractured and brecciated (fig. A12) by brittle reactivation along the fault zone (Gammons, 1988; Lund and others, 1997). Oxidation caused by low-temperature alteration systems is common along these brittle features. The overprinting of brittle deformation indicates that this fault was active from at least the Cretaceous until the late Eocene. The sense of Eocene and post-Eocene offset continued to be down-to-the-east as shown by the localization of rocks of the Thunder Mountain caldera on the east side of the shear zone (see "Caldera Structures" section).

The major northeast-trending Bargamin Creek fault (northern pl. 2) controls a segment of the Salmon River along the northern boundary of the forest and the drainage of Bargamin Creek to the north. This prominent lineament disrupts structural trends and juxtaposes rocks of different age and origin (Weis and others, 1972; Cater and others, 1973; Greenwood and Morrison, 1973; Lewis and others, 1990) and it may consist of a number of fault strands north of the forest (Lewis and others, 1990). Ductile shear fabrics have been noted along the Bargamin Creek fault (Cater and others, 1973; Greenwood and Morrison, 1973) and Cater and others (1973) suggested that it could be a strike-slip fault. Fold trends in offset metamorphic rocks across the Bargamin Creek fault suggest it may have been a left-lateral tear fault related to Cretaceous thrust faults exposed north and east of the forest (K. Lund, unpub. data, 2002). Evidence of Eocene down-to-the-west, left-lateral motion is recorded by mylonitized Eocene dikes in the fault zone (Lewis and others, 1998). The juxtaposition of Eocene granite $(\mathrm{Tg})$ with Mesoproterozoic metamorphic rocks across the fault (see pl. 2 and Lewis and others, 1990) indicates postearly Eocene down-to-the-west offset of several kilometers and continued reactivation of the zone. Emplacement of the Chamberlain Basin pluton to the south (fig. A3) may have been partly controlled by extension related to the intersection of the Bargamin Creek and Johnson Creek-Profile Gap shear zones.

\section{Caldera Structures}

The internal part of the Thunder Mountain caldera (fig. A3) in the eastern part of the forest is dominated by north-northeast-trending normal faults similar to those described in the preceding section. However, the margins of the caldera are well defined by curved ring faults (central pl. 2). The western margin of the caldera was thought to be defined by a north-northeast-trending fault described as a ring fracture (Leonard and Marvin, 1982). However, this study has shown that (1) the fault in question was a segment of the much more regional and older Johnson Creek-Profile Gap shear zone and (2) a curvilinear normal fault at the margin of the volcanic rocks is the fault controlling subsidence of the west side of the caldera as well as controlling the present outcrop distribution of the volcanic rocks.

\section{Normal Faults}

In the area between the Johnson Creek-Profile Gap shear zone and the Salmon River suture (central pl. 2), several long normal faults have been mapped in Late Cretaceous granite. Most of these were active during the Tertiary and Quaternary but because of the lack of marker horizons, the sense or amount of offset is difficult to determine. The most important of these is a northwest-trending fault controlling Lake Creek and the middle part of the Secesh River called the Lake Creek-Secesh River fault (fig. A3; western pl. 2; Capps, 1941). Capps noted a series of hot springs lying along the trace of this fault. A large amount of alluvium, some of which is glacial moraine and outwash, lies along the west side of the fault and, despite glacial reworking and lack of offset indicators, a sense of down-to-the-west movement is indicated. A southeastern extension of this fault, along Burnt Log Creek (south-central pl. 2), is inferred to have had post-Cretaceous down-to-the-west movement based on offset of porphyritic biotite granodiorite (Kpgdf). The northwest orientation and great length of this fault (at least $50 \mathrm{~km}$ ) suggest that normal faulting on this trend may have been a reactivation of Cretaceous or older structures. A parallel down-to-the-east normal fault called the Secesh Meadows fault (Capps, 1941) controls the upper part of the Secesh River (west-central pl. 2). Basin-fill deposits in the Secesh Meadows contain Tertiary beds under younger gravels (Capps, 1940), showing that activity along 
this fault was occurring by the late Tertiary. A north-trending down-to-the-east normal fault controls the Warren Creek basin (west-central pl. 2; Reed, 1937) and, because placering activity uncovered Tertiary beds underlying Quaternary gravels (Capps, 1941), activity on this fault was also shown to date at least from the late Tertiary. A similar situation exists for thrust faults in the western part of the forest. Brittle deformation along the Rapid River is especially apparent where chloritic breccia formed in Early Cretaceous(?) and Late Jurassic quartz diorite plutons (KJqd) due to normal-fault reactivation along the Rapid River thrust fault zone (Hamilton, 1963; Gray, 2001: this study). Thrust faults in the northern Seven Devils Mountains were also reactivated by normal faults (Detra, 1980).

\section{Late Tertiary Structures of the Weiser Embayment}

Based on interpretation of ages and relationships among layered rocks, structure, and intrusive rocks, a northeast- or north-trending intra-arc structure is suspected to underlie the axis of the Miocene Weiser Embayment and to have impacted location and orientation of the basin. Miocene and younger structural development of the western part of the forest was dominated by deformation related to three main structural elements: (1) Normal faults reactivated earlier island-arc structures parallel to the Snake River (west edge pl. 1) and formed the northeast-trending Snake River fault system. (2) North-trending normal faults of the Long Valley fault system (east side pl. 1), located between the Salmon River Mountains on the east and the main exposures of the Columbia River Basalt Group (Weiser embayment) on the west, are nearly parallel to and reactivate the Salmon River suture, resulting in a series of west-tilted blocks (Lund, 1984; Lund and others, 1993; Tikoff and others, 2001). (3) The northwest-trending Paddock Valley fault system formed a large down-dropped basin that crosses the southern part of plate 1 (Fitzgerald, 1982). These fault systems are cut off by younger structures related to formation of the Snake River Plain near the southwest corner of plate 1 .

Examination of the Miocene depositional record in the western part of the forest indicates that by the beginning of the Neogene a north-northeast-trending uplift was already apparent along the present-day area of the Hitt-Cuddy-Seven Devils Mountains (fig. A3). This proto-highland is what separated the Weiser embayment of the Columbia River Basalt Group from the Clearwater embayment to the north (see Swanson and others, 1979). Development of this highland along the Snake River progressed throughout the Neogene but most of the uplift followed extrusion of Miocene basalt. Uplift occurred by means of normal-fault reactivation of earlier compressional faults along a $25-\mathrm{km}$-wide zone. Both the Wildhorse fault and the Connor Creek fault (western pl. 1) were reactivated as down-to-the-west normal faults (Mann, 1989, 1991). This predominant west-side-down fault movement resulted in an average of 1,000 $\mathrm{m}$ of offset across the Snake
River from the Seven Devils Mountains to the Oregon Plateau west of the forest (Fitzgerald, 1982).

The 30-km-wide Long Valley fault system (eastern pl. 1) forms the eastern margin of the Weiser embayment (fig. A3). This fault system generally parallels the Salmon River suture, and many of the faults in the zone are probably reactivated discrete faults related to earlier shear zones. Although responsible for the overall high elevation of the Idaho batholith terrane relative to that of the island-arc rocks, most of the youngest, most well-exposed faults of this system are east-side-down, with west-dipping fault blocks. There is about $1,000 \mathrm{~m}$ of east-side-down offset along the west side of Long Valley in the West Mountains area (Schmidt and Mackin, 1970; Fitzgerald, 1982). The Long Valley fault system controlled drainages all along the west side of the Salmon River Mountains; the north-flowing Little Salmon River and the south-flowing Payette and upper Weiser Rivers (eastern pl. 1) are controlled by structures of the Long Valley fault system. Because of the north-south structural control of drainages related to the Long Valley fault system, most of the post-Miocene sediments derived from the Idaho batholith to the east were transported southward down Long Valley and the Payette River rather than into the Weiser embayment. Movements on this fault system occurred after deposition of the Grande Ronde Basalt (Tcrg), from about 14 Ma to the present (Schmidt and Mackin, 1970; Fitzgerald, 1982).

The northwest-trending Paddock Valley fault system (southern pl. 1) is a 50- to 80-km-wide diffuse zone of late Tertiary to Holocene normal faults (a number of these faults have only minor movement) and related folds. The greatest offsets are along normal faults at the margin of the system, which probably formed the vents for flows of the basalt of Weiser (Tw; Fitzgerald, 1982). The transverse nature of this fault system segmented the uplift near the Snake River and formed some of the bounding faults for the uplifts of the Hitt Mountains and Cuddy Mountain (western and central pl. 1). Because of the well-defined uplifts and basins, which were caused by activity of the Paddock Valley fault system, flows of the basalt of Weiser (Tw) and sediments of the Idaho Group (QTi) were confined to the local Paddock Valley basin area (southern pl. 1; McIntyre, 1976; Fitzgerald, 1982). The Paddock Valley fault system is genetically related to early Snake River Plain faulting (Fitzgerald, 1982) centered in southern Idaho.

Continued growth of uplifts and basins from just before eruption of the basalt of Weiser (Tw) have resulted in the present topography and stream patterns along the western side. The Hitt Mountains uplift (western pl. 1) is a northwest-trending anticline. Cuddy Mountain (central pl. 1) is a fault-bounded uplift block. The southern part of the Seven Devils Mountains (northern pl. 1) is a homocline that dips south. The Salmon River Mountains (pl. 2) are a high plateau that is bounded on the west by the Long Valley fault system (eastern pl. 1). Many of the present drainages are structurally controlled as previously described and others became antecedent streams as incision kept pace with uplift. 


\section{References Cited}

Aliberti, E.A., 1988, A structural, petrographic, and isotopic study of the Rapid River area and selected mafic complexes in the northwestern United States-Implications for the evolution of an abrupt island arc-continent boundary: Cambridge, Mass., Harvard University Ph.D. thesis, 194 p.

Aliberti, E., and Manduca, C.A., 1988, Field guide to a transect across an island arc-continent boundary in west-central Idaho, in Lewis, S.E., and Berg, R.B., eds., Precambrian and Mesozoic plate margins, Montana, Idaho, and Wyoming, with field guides for the 8th International Conference on Basement Tectonics: Montana Bureau of Mines and Geology Special Publication 96, p. 181-189.

Anderson, A.L., 1942, Endomorphism of the Idaho batholith: Geological Society of America Bulletin, v. 53, p. 1099-1126.

Anderson, A.L., 1975, Precambrian (1500 m.y. old) rocks of central Idaho - The Salmon River Arch and its role in Cordilleran sedimentation and tectonics: American Journal of Science, v. 275-A, p. 437-467.

Armstrong, R.L., Taubeneck, W.H., and Hales, P.L., 1977, Rb/ $\mathrm{Sr}$ and $\mathrm{K} / \mathrm{Ar}$ geochronometry of Mesozoic granitic rocks and their Sr isotopic composition, Oregon, Washington, and Idaho: Geological Society of America Bulletin, v. 88, p. 397-411.

Ave Lallemant, H.G., 1995, Pre-Cretaceous tectonic evolution of the Blue Mountains province, northeastern Oregon, in Vallier, T.L., and Brooks, H.C., eds., Geology of the Blue Mountains region of Oregon, Idaho, and WashingtonPetrology and tectonic evolution of pre-Tertiary rocks of the Blue Mountains region: U.S. Geological Survey Professional Paper 1438, p. 271-304.

Ave Lallemant, H.G., Phelps, D.W., and Sutter, J.F., 1980, ${ }^{40} \mathrm{Ar} /{ }^{39} \mathrm{Ar}$ ages of some pre-Tertiary plutonic and metamorphic rocks of eastern Oregon and their geologic relationships: Geology, v. 8, p. 371-374.

Ave Lallemant, H.G., Schmidt, W.J., and Kraft, J.L., 1985, Major Late Triassic strike-slip displacement in the Seven Devils terrane, Oregon and Idaho-A result of left-oblique plate convergence?: Tectonophysics, v. 119, p. 299-328.

Balcer, D.E., $1980,{ }^{40} \mathrm{Ar} /{ }^{39} \mathrm{Ar}$ ages and REE geochemistry of basement terranes in the Snake River Canyon, northeastern Oregon-western Idaho: Columbus, Ohio, The Ohio State University Master's thesis, $111 \mathrm{p}$.

Bishop, E.M., 1995, Mafic and ultramafic rocks of the Baker terrane, eastern Oregon, and their implications for terrane origin, in Vallier, T.L., and Brooks, H.C., eds., Geology of the Blue Mountains region of Oregon, Idaho, and Washington-Petrology and tectonic evolution of pre-Tertiary rocks of the Blue Mountains region: U.S. Geological Survey Professional Paper 1438, p. 221-246.
Blake, D.E., 1991, Geology of the western Idaho suture zone in the Salmon River gorge, west-central Idaho: Pullman, Wash., Washington State University Ph.D. dissertation, 330 p.

Bond, J.G., 1978, Geologic map of Idaho: Idaho Bureau of Mines and Geology, scale 1:500,000.

Bonnichsen, B., 1987, Pre-Cenozoic geology of the West Mountain-Council Mountain-New Meadows area, west-central Idaho, in Vallier, T.L., and Brooks, H.C., eds., Geology of the Blue Mountains region of Oregon, Idaho, and WashingtonThe Idaho batholith and its border zone: U.S. Geological Survey Professional Paper 1436, p. 151-170.

Bookstrom, A.A., Johnson, B.R., Cookro, T.M., Lund, K., Watts, K.C., King, H.D., Kleinkopf, M.D., Pitkin, J.A., Sanchez, J.D., and Causey, J.D., 1998, Potential mineral resources, forest, Idaho-Description and probabilistic estimation: U.S. Geological Survey Open-File Report 98-219-A, 254 p.

Brooks, H., 1979, Plate tectonics and the geologic history of the Blue Mountains: Oregon Geology, v. 41, p. 71-80.

Brooks, H.C., and Vallier, T.L., 1978, Mesozoic rocks and tectonic evolution of eastern Oregon and western Idaho, in Howell, D.G., and McDougall, K.A., eds., Mesozoic paleogeography of the Western United States (Pacific Coast Paleogeography Symposium 2): Los Angeles, Calif., Society of Economic Paleontologists and Mineralogists, Pacific Section, p. 133-145.

Bruce, W., 1971, Geology, mineral deposits, and alteration of parts of the Cuddy Mountain District, western Idaho: Corvallis, Oreg., Oregon State University Ph.D. dissertation, $165 \mathrm{p}$.

Campbell, I., and Loofbourow, J.S., Jr., 1962, Geology of the magnesite belt of Stevens County, Washington: U.S. Geological Survey Bulletin 1142-F, 53 p.

Capps, S.R., 1940, Gold placers of the Secesh Basin, Idaho County, Idaho: Idaho Bureau of Mines and Geology Pamphlet 52, 43 p.

Capps, S.R., 1941, Faulting in western Idaho and its relation to the high placer deposits: Idaho Bureau of Mines and Geology Pamphlet 56, 20 p.

Cater, F.W., Pinckney, D.M., Hamilton, W.B., Parker, R.L., Weldin, R.D., Close, T.J., and Zilka, N.T., 1973, Mineral resources of the Idaho Primitive Area and vicinity, Idaho: U.S. Geological Survey Bulletin 1304, 431 p.

Connor, J.J., and Evans, K.V., 1986, Geologic map of the Leesburg quadgrangle, Lemhi County, Idaho: U.S. Geological Survey Miscellaneous Field Studies Map MF-1880, scale $1: 62,500$. 
Cook, E.F., 1954, Mining geology of the Seven Devils Region: Idaho Bureau of Mines and Geology Pamphlet 97, 22 p.

Cookro, T.M., Silberman, M.L., and Berger, B.R., 1988, Gold-tungsten-bearing hydrothermal deposits in the Yellow Pine mining district, Idaho, in Schafer, R.W., Cooper, J.J., and Vikre, P.G., eds., Bulk mineable precious metal deposits of the western United States: Reno, Nev., Geological Society of Nevada, p. 577-624.

Davidson, G.F., 1990, Cretaceous tectonic history along the Salmon River suture zone near Orofino, Idaho: Metamorphic, structural and ${ }^{40} \mathrm{Ar} /{ }^{39} \mathrm{Ar}$ constraints: Corvallis, Oreg., Oregon State University Master's thesis, 143 p.

Detra, E.H., 1980, Structural investigation of a section through the Seven Devils Mountains, Idaho: Missoula, Mont., University of Montana Master's thesis, $49 \mathrm{p}$.

Devlin, W.J., Bond, G.C., and Brueckner, H.K., 1985, An assessment of the age and tectonic setting of volcanics near the base of the Windermere Supergroup in northeastern Wawhington-Implications for latest Proterozoic-earliest Cambrian continental separation: Canadian Journal of Earth Sciences, v. 22, p. 829-837.

Dickinson, W.R., 1979, Mesozoic fore-arc basin in central Oregon: Geology, v. 7, p. 166-170.

Dickinson, W.R., and Thayer, T.P., 1978, Paleogeographic and paleotectonic implications of Mesozoic stratigraphy and structure in the John Day inlier of central Oregon, in Howell, D.G., and McDougall, K.A., eds., Mesozoic paleogeography of the Western United States (Pacific Coast Paleogeography Symposium 2): Los Angeles, Calif., Society of Economic Paleontologists and Mineralogists, Pacific Section, p. 147-161.

Doughty, P.T., and Chamberlain, K.R., 1996, Salmon River Arch revisited-New evidence for 1370 Ma rifting near the end of deposition in the Middle Proterozoic Belt basin: Canadian Journal of Earth Science, v. 33, p. 1037-1052.

Ehlers, T.A., Chan, M.A., and Link, P.A., 1997, Proterozoic tidal, glacial, and fluvial sedimentation in Big Cottonwood Canyon, Utah, in Link, P.K., and Kowallis, B.J., eds., Geological Society of America field trip guide book: Salt Lake City, Utah, Brigham Young University Geology Studies, 42, pt. 1, p. 31-58.

Ekren, E.B., 1988, Stratigraphic and structural relations of the Hoodoo Quartzite and Yellowjacket Formation of Middle Proterozoic age from Hoodoo Creek eastward to Mount Taylor, central Idaho, with a Geologic map of the region between the Middle Fork of the Salmon River and the Salmon River: U.S. Geological Survey Bulletin 1570, 17 p.
Evans, J.G., 1987, Geology of the Stensgar Mountain quadrangle, Stevens County, Washington: U.S. Geological Survey Bulletin 1679, 23 p.

Evans, K.V., 1981, Geology and geochronology of the eastern Salmon River Mountains, Idaho, and implications for regional Precambrian tectonics: University Park, Penn., The Pennsylvania State University Ph.D. dissertation, 222 p.

Evans, K.V., 1986, Middle Proterozoic deformation and plutonism in Idaho, Montana, and British Columbia, in Roberts, S.M., ed., Belt Supergroup: Montana Bureau of Mines and Geology Special Publication 94, p. 237-244.

Evans, K.V., 1998, The Yellowjacket Formation of east-central Idaho, in Berg, R.B., ed., Proceedings of Belt Symposium III: Montana Bureau of Mines and Geology Special Publication 111 , p. 15-29.

Evans, K.V., Aleinikoff, J.N., Obradovich, J.D., and Fanning, C.M., 2000, SHRIMP U-Pb geochronology of volcanic rocks, Belt Supergroup, western Montana-Evidence for rapid deposition of sedimentary strata: Canadian Journal of Earth Sciences, v. 37, p. 1287-1300.

Evans, K.V., and Fischer, L.B., 1986, U-Pb geochronology of two augen gneiss terranes, Idaho- -New data and tectonic implications: Canadian Journal of Earth Sciences, v. 23, p. 1919-1927.

Evans, K.V., and Green, G.N., compilers, 2003, Geologic map of the Salmon National Forest and vicinity, east-central Idaho: U.S. Geological Survey Geologic Investigations Series I-2765, scale 1:100,000, 19-p. pamphlet.

Evans, K.V., and Lund, K., 1981, The Salmon River “Arch”?: Geological Society of America Abstracts with Programs, v. 13, p. 448.

Evans, K.V., Lund, K., Aleinikoff, J.N., and Fanning, C.M., 1997, SHRIMP U-Pb age of Late Proterozoic volcanism in central Idaho: Geological Society of America Abstracts with Programs, v. 29, no. 6, p. 196.

Evans, K.V., Lund, K., Nowlan, G.A., and Esparza, L.E., 1994, Geologic and mineral resource potential map of the Salmon River and Cove Mountain Additions to the Frank Church-River of No return Wilderness, Idaho County, Idaho: U.S. Geological Survey Miscellaneous Field Studies Map MF-2272, scale 1:50,000.

Evans, K.V., and Zartman, R.E., 1990, U-Th-Pb and Rb-Sr geochronology of Middle Proterozoic granite and augen gneiss, Salmon River Mountains, east-central Idaho: Geological Society of America Bulletin, v. 102, p. 63-73. 
Field, C.W., Briskey, J.A., Henricksen, T.A., Jones, M.B., Schmuck, R.A., and Bruce, W.R., 1975, Chemical trends in Mesozoic plutons associated with porphyry-type metallization of the Pacific Northwest: Society of Mining Engineers A.I.M.E. Preprint Number 75-L-359, p. 26.

Fifarek, R.H., Juhas, A.P., and Field, C.W., 1994, Geology, mineralization, and alteration of the Red Ledge volcanogenic massive sulfide deposit, western Idaho, in Vallier, T.L., and Brooks, H.C., eds., Geology of the Blue Mountains region of Oregon, Idaho, and Washington-Stratigraphy, physiography, and mineral resources of the Blue Mountains region: U.S. Geological Survey Professional Paper 1439, p. 113-150.

Fisher, F.S., McIntyre, D.H., and Johnson, K.M., 1992, Geologic map of the Challis $1^{\circ} \times 2^{\circ}$ quadrangle, Idaho: U.S. Geological Survey Miscellaneous Investigations Series Map I-1819, scale 1:250,000.

Fitzgerald, J.F., 1982, Geology and basalt stratigraphy of the Weiser embayment, west-central Idaho, in Bonnichsen, B., and Breckenridge, R.M., eds., Cenozoic geology of Idaho: Idaho Bureau of Mines and Geology Bulletin 26, p. 103-128.

Fleck, R.J., and Criss, R.E., 1985, Strontium and oxygen isotopic variations in Mesozoic and Tertiary plutons of central Idaho: Contributions to Mineralogy and Petrology, v. 90 , p. 291-308.

Follo, M.F., 1994, Sedimentology and stratigraphy of the Martin Bridge Limestone and Hurwal Formation (Upper Triassic to Lower Jurassic) from the Wallowa terrane, Oregon, in Vallier, T.L., and Brooks, H.C., eds., Geology of the Blue Mountains region of Oregon, Idaho, and Washington-Stratigraphy, physiography, and mineral resources of the Blue Mountains region: U.S. Geological Survey Professional Paper 1439, p. 1-27.

Frankhauser, R.E., 1969, Geology and mineralization of the southern Cuddy Mountains, Washington County, Idaho: Corvallis, Oreg., Oregon State University Master's thesis, $137 \mathrm{p}$.

Gammons, C.H., 1988, Studies in hydrothermal phenomena-(1) The solubility of silver sulfide in aqueous sulfide solutions to $300^{\circ} \mathrm{C}$; (2) A paragenesis and fluid inclusion study of polymetallic vein mineralization in the Big Creek mining district, central Idaho: University Park, Penn., The Pennsylvania State University Ph.D. dissertation, 337 p.

Gammons, C.H., Rose, A.W., Snee, L.W., and Lund, K., 1985, Paragenesis, fluid inclusions, and Ar dating of the Big Creek mining district, Valley County, central Idaho: Geological Society of America Abstracts with Programs, v. 17, p. 588.
Gaston, M.P., and Bennett, E.H., 1979, Geologic map of the Grangeville quadrangle: Idaho Bureau of Mines and Geology Geologic Map Series, scale 1:250,000.

Getty, S.R., Selverstone, J., Wernicke, B.P., Jacobsen, S.B., Aliberti, E., and Lux, D.R., 1993, Sm-Nd dating of multiple garnet growth events in an arc-continent collision zone, northwestern U.S. Cordillera: Contributions to Mineralogy and Petrology, v. 115, p. 45-57.

Gray, K.D., 2001, Contrasting structural histories between the Salmon River belt and the Wallowa terrane; implications for the timing and evolution of the Salmon River suture: Moscow, Idaho, University of Idaho Master's thesis, $54 \mathrm{p}$.

Greenwood, W.R., and Morrison, D.A., 1973, Reconnaissance geology of the Selway-Bitterroot Wilderness Area: Idaho Bureau of Mines and Geology Pamphlet, $30 \mathrm{p}$.

Gualtieri, J.L., and Simmons, G.C., 1978, Preliminary geologic map of the Hells Canyon area, Idaho County, Idaho, and Wallowa County, Oregon: U.S. Geological Survey Open-File Report 78-805, scale 1:48:000.

Hamilton, W., 1963, Metamorphism in the Riggins region, western Idaho: U.S. Geological Survey Professional Paper 436, $95 \mathrm{p}$.

Hamilton, W., 1969, Reconnaissance geologic map of the Riggins quadrangle, west-central Idaho: U.S. Geological Survey Miscellaneous Geologic Investigations Map I-579, scale 1:125,000.

Hamilton, W., 1978, Mesozoic tectonics of the western United States, in Howell, D.G., and McDougall, K.A., eds., Mesozoic paleogeography of the Western United States (Pacific Coast Paleogeography Symposium 2): Los Angeles, Calif., Society of Economic Paleontologists and Mineralogists, Pacific Section, p. 33-70.

Harper, G.D., and Link, P.K., 1986, Geochemistry of Upper Proterozoic rift-related volcanics, northern Utah and southeastern Idaho: Geology, v. 14, p. 864-867.

Henricksen, T.A., 1975, Geology and mineral deposits of the Mineral-Iron Mountain District, Washington County, Idaho, and of a metallized zone in western Idaho and eastern Oregon: Corvallis, Oreg., Oregon State University Ph.D. dissertation, $205 \mathrm{p}$.

Hobbs, S.W., and Hays, W.H., 1990, Ordovician and older rocks of the Bayhorse area, Custer County, Idaho: U.S. Geological Survey Bulletin 1891, 40 p.

Hobbs, S.W., Hays, W.H., and McIntyre, D.H., 1991, Geologic map of the Bayhorse area, central Custer County, Idaho: U.S. Geological Survey Miscellaneous Investigations Series Map I-1882, scale 1:62,500. 
Hooper, P.R., and Swanson, D.A., 1990, The Columbia River Basalt Group and associated volcanic rocks of the Blue Mountains province, in Walker, G.W., ed., Geology of the Blue Mountains region of Oregon, Idaho, and Washington-Cenozoic geology of the Blue Mountains region: U.S. Geological Survey Professional Paper 1437, p. 63-100.

Hotz, P.E., Lanphere, M.A., and Swanson, D.A., 1977, Triassic blueschist from northern California and north-central Oregon: Geology, v. 5, p. 659-663.

Janecke, S.U., 1992, Kinematics and timing of three superposed extensional systems, east-central Idaho-Evidence for an Eocene tectonic transition: Tectonics, v. 11, p. 1121-1138.

Juras, D.S., 1973, Pre-Miocene geology of the northwest part of the Olds Ferry quadrangle, Washington County, Idaho: Moscow, Idaho, University of Idaho Master's thesis, 82 p.

King, J.R., 1971, The geology of the southeastern Cuddy Mountain district, western Idaho: Corvallis, Oreg., Oregon State University Master's thesis, 78 p.

Kinoshita, W.T., 1962, A gravity survey of part of the Long Valley district, Idaho: U.S. Geological Survey Open-File Report, $11 \mathrm{p}$.

Kirkham, V.R.D., 1931, Revisions of the Payette and Idaho Formations: Journal of Geology, v. 38, p. 652-653.

Kirkpatrick, G.E., 1974, Geology and ore deposits of the Big Creek area, Idaho and Valley Counties, Idaho: Moscow, Idaho, University of Idaho M.S. thesis, 92 p.

Kleinkopf, M.D., 1998, Aeromagnetic and gravity studies of Payette National Forest, Idaho: U.S. Geological Survey Open-File Report 98-219-D, 19 p.

Leonard, B.F., 1962, Old metavolcanic rocks of the Big Creek area, central Idaho, in Short papers in geology, hydrology, and topography: U.S. Geological Survey Professional Paper 450-B, p. B11-B15.

Leonard, B.F., 1963, Syenite complex older than the Idaho batholith, Big Creek quadrangle, central Idaho, in Short papers in geology, hydrology, and topography: U.S. Geological Survey Professional Paper 450-E, p. E93-E97.

Leonard, B.F., and Marvin, R., 1982, Temporal evolution of the Thunder Mountain caldera and related features, central Idaho, in Bonnichsen, B., and Breckenridge, R.M., eds., Cenozoic geology of Idaho: Idaho Bureau of Mines and Geology Bulletin 26, p. 23-41.

Lewis, C.F., and Lewis, R.D., 1982, Fossil evidence of Ordovician age roof pendants previously considered as Precambrian in the Idaho batholith: Geological Society of America Abstracts with Programs, v. 14, p. 265.
Lewis, R.S., Burmester, R.F., and Bennett, E.H., 1998, Metasedimentary rocks between the Bitterroot and Atlanta Lobes of the Idaho batholith and their relationship to the Belt Supergroup, in Berg, R.B., ed., Belt Symposium III: Montana Bureau of Mines and Geology Special Publication 112, p. 130-144.

Lewis, R.S., Burmester, R.F., Bennett, E.H., and White, D.L., 1990, Preliminary geologic map of the Elk City region, Idaho County, Idaho: Idaho Geological Survey Technical Report 90-2, scale 1:100,000.

Lewis, R.S., Burmester, R.F., and Frost, T.P., 1996, Proterozoic granite and augen gneiss of central Idaho-A result of rifting during Belt Supergroup deposition?: Geological Society of America Abstracts with Program, v. 28, no. 7, p. 376.

Link, P.K., Christie-Blick, N., Devlin, W.J., Elston, D.P., Horodyski, R.J., Levy, M., Miller, J.M.G., Pearson, R.C., Prave, A., Stewart, J.H., Winston, D., Wright, L.A., and Wrucke, C.T., 1993, Middle and Late Proterozoic stratified rocks of the western U.S. Cordillera, Colorado Plateau, and Basin and Range Province, in Reed, J.C., Jr., Bickford, M.E., Houston, R.S., Link, P.K., Rankin, D.W., Sims, P.K., and Van Schmus, W.R., eds., Precambrian - Conterminous U.S.: Boulder, Colo., Geological Society of America, The Geology of North America, C-2, p. 463-595.

Link, P.K., Miller, J.M.G., and Christie-Blick, N., 1994, Glacial-marine facies in a continental rift environment- $-\mathrm{Neo}-$ proterozoic rocks of the western United States Cordillera, in Deynooux, M., Miller, J.M.B., Domack, E.W., Eyles, N., Fairchild, I.J., and Young, G.M., eds., International Geological Correlation Project 260-Earth's Glacial Record: London, Cambridge University Press, p. 29-46.

Livingston, D.C., 1932, A major overthrust in western Idaho and northeastern Oregon: Northwest Science, v. 6, p. 31-36.

Lund, K., 1980, Geology of the Whistling Pig pluton, Selway-Bitterroot Wilderness, Idaho: Boulder, Colo., University of Colorado Master's thesis, $115 \mathrm{p}$.

Lund, K., 1984, Tectonic history of a continent-island arc boundary, west-central Idaho: University Park, Penn., The Pennsylvania State University Ph.D. dissertation, 210 p.

Lund, K., 1988, The Salmon River suture, western Idaho-An island arc-continent boundary, in Lewis, S.E., and Berg, R.B., eds., Precambrian and Mesozoic plate margins, Montana, Idaho, and Wyoming with field guides for the 8th International Conference on Basement Tectonics: Montana Bureau of Mines and Geology Special Publication 96, p. 103-110. 
Lund, K., 1995, Metamorphic and structural development of island-arc rocks in the Slate Creek-John Day Creek area, west-central Idaho, in Vallier, T.L., and Brooks, H.C., Geology of the Blue Mountains region of Oregon, Idaho, and Washington-Petrology and tectonic evolution of pre-Tertiary rocks of the Blue Mountains region: U.S. Geological Survey Professional Paper 1438, p. 517-540.

Lund, K., Aleinikoff, J.N., Evans, K.V., and Fanning, C.M., 2003, SHRIMP U-Pb geochronology of Neoproterozoic Windermere Supergroup, central Idaho-Implications for regional synchroneity of Sturtian glaciation and associated rifting: Geological Society of America Bulletin, v. 115, no. 3, p. 349-372.

Lund, K., Alminas, H.V., Kleinkopf, M.D., Ehmann, W.J., and Bliss, J.D., 1990, Preliminary mineral resource assessment of the Elk City $1^{\circ} \times 2^{\circ}$ quadrangle, Idaho and Montana-Compilation of geologic, geochemical, geophysical, and mineral deposits information: U.S. Geological Survey Open-File Report 89-0016, 118 p.

Lund, K., Derkey, P.D., Brandt, T.R., and Oblad, J.R., 1998, Digital geologic map database of the forest and vicinity, Idaho: U.S. Geological Survey Open-File Report 98-219B, scale 1:100,000.

Lund, K., and Esparza, L.E., 1990, Mineral resources of the Gospel-Hump Wilderness, Idaho County, Idaho: U.S. Geological Survey Bulletin 1812, 19 p.

Lund, K., Evans, K.V., and Esparza, L.E., 1983, Mineral resource potential map of the Special Mining Management Zone-Clear Creek, Lemhi County, Idaho: U.S. Geological Survey Miscellaneous Field Studies Map MF-1576-A, scale 1:50,000.

Lund, K., Kuntz, M.A., Manduca, C.A., Gammons, C.H., Evans, K.V., Tysdal, R.G., Winkler, G.R., and Connor, J.J., 1997, Geology of the western Salmon River Mountains, Valley and Idaho Counties, west-central Idaho: U.S. Geological Survey Miscellaneous Investigations Series Map I-2599, scale 1:100,000.

Lund, K., McCollough, W.F., and Price, E.H., 1993, Geologic map of the Slate Creek-John Day Creek area, Idaho County, Idaho: U.S. Geological Survey Miscellaneous Investigations Series Map I-2299, scale 1:50,000.

Lund, K., Mutschler, F.M., Pawlowski, M.R., Hall, B.S., Bruce, R.M., and Evans, K.V., 1992, Geologic maps of the Big Mallard, Middle Bargamin, and Magruder Additions to the Frank Church-River-of-No-Return Wilderness, Lemhi and Idaho Counties, Idaho: U.S. Geological Survey Miscellaneous Field Studies Map MF-2204, scale 1:50,000.
Lund, K., Rehn, W.M., and Holloway, C.D., 1983, Geologic map of the Blue Joint Wilderness Study Area, Ravalli County, Montana, and the Blue Joint Roadless Area, Lemhi County, Idaho: U.S. Geological Survey Miscellaneous Field Studies Map MF-1557-B, scale 1:50,000.

Lund, K., Scholten, R., and McCollough, F.M., 1983, Consequences of interfingered lithologies in the Seven Devils island arc: Geological Society of America Abstracts with Programs, v. 15, p. 284.

Lund, K., and Snee, L.W., 1988, Metamorphism, structural development, and age of the continent-island arc juncture in west-central Idaho, in Ernst, W.G., ed., Metamorphism and crustal evolution of the Western United States: Englewood Cliffs, N.J., Prentice-Hall, Rubey Volume VII, p. 296-331.

Lund, K., Snee, L.W., and Evans, K.V., 1986, Age and genesis of precious metals deposits, Buffalo Hump district, central Idaho-Implications for depth of emplacement of quartz veins: Economic Geology, v. 81, p. 990-996.

Manduca, C.A., Kuntz, M.A., and Silver, L.T., 1993, Emplacement and deformation history of the western margin of the Idaho batholith near McCall-Influence of a major terrane boundary: Geological Society of America Bulletin, v. 105, p. 749-765.

Manduca, C.C.A., 1988, Geology and geochemistry of the oceanic arc-continent boundary in the western Idaho batholith near McCall: Pasadena, Calif., California Institute of Technology Ph.D. dissertation, 272 p.

Mangham, J.R., 1994, Geology of the Peck Mountain massive sulfide prospect, Adams County, Idaho, in Vallier, T.L., and Brooks, H.C., eds., Geology of the Blue Mountains region of Oregon, Idaho, and Washington-Stratigraphy, physiography, and mineral resources of the Blue Mountains region: U.S. Geological Survey Professional Paper 1439, p. 101-111.

Mann, G.M., 1989, Seismicity and Late Cenozoic faulting in the Brownlee Dam area, Oregon-Idaho-A preliminary report: U.S. Geological Survey Open-File Report 89-429, 46 p.

Mann, G.M., 1991, Geology and seismicity of the Pine Valley and Cuddy Mountain region, Oregon-Idaho: Hayward, Calif., California State University M.S. thesis, 230 p.

May, T.P., 1984, The geology of a portion of the Marshall Lake district, Idaho County, Idaho: Moscow, Idaho, University of Idaho M.S. thesis, $101 \mathrm{p}$.

McCafferty, A.E., 1992, Aeromagnetic maps and terrace-magnetization map centered on the Idaho batholith and Challis volcanic field, northwestern United States: U.S. Geological Survey Geophysical Investigations Map GP-994, 2 sheets, scale $1: 1,000,000$. 
McCafferty, A.E., Kucks, R.P., Hill, P.L., and Racey, S.D., 1999, Aeromagnetic map for the State of Idaho-A web site for distribution of data: U.S. Geological Survey Open-File Report 99-371. Available at URL http://pubs.usgs.gov/ of/1999/ofr-99-0371.

McClelland, W.C., Tikoff, B., and Manduca, C.A., 2000, Twophase evolution of accretionary margins - Examples from the North American Cordillera: Tectonophysics, v. 326, p. 37-55.

McIntyre, D.H., 1976, Reconnaissance geologic map of the Weiser geothermal area, Washington County, Idaho: U.S. Geological Survey Miscellaneous Field Studies Map MF-745, scale 1:62,500.

McIntyre, D.H., Ekren, E.B., and Hardyman, R.F., 1982, Stratigraphic and structural framework of the Challis Volcanics in the eastern half of the Challis $1^{\circ} \times 2^{\circ}$ quadrangle, in Bonnichsen, B., and Breckenridge, R.M., eds., Cenozoic geology of Idaho: Idaho Bureau of Mines and Geology Bulletin 26, p. 3-22.

Miller, F.K., and Whipple, J.W., 1989, The Deer Trail Group-Is it part of the Belt Supergroup?, in Joseph, N.L., and others, eds., Geologic guidebook for Washington and adjacent areas: Washington Division of Geologic and Earth Resources Information Circular 86, p. 3-21.

Mitchell, V.E., and Bennett, E.H., 1979, Geologic map of the Baker quadrangle, Idaho: Idaho Bureau of Mines and Geology Geologic Map Series, scale 1:250,000.

Morganti, J.M., 1972, Geology and ore deposits of the Seven Devils Volcanics, Seven Devils mining district, Hell's Canyon, Idaho: Corvallis, Oreg., Oregon State University Master's thesis, $152 \mathrm{p}$.

Onasch, C.M., 1977, Structural evolution of the western margin of the Idaho batholith in the Riggins, Idaho area: University Park, Penn., The Pennsylvania State University Ph.D. dissertation, $196 \mathrm{p}$.

Otto, B.R., 1976, Structure and petrology of the Sheepeater Peak area, Idaho Primitive Area, Idaho: Missoula, Mont., University of Montana Master's thesis, 68 p.

Reed, J.C., 1937, Geology and ore deposits of the Warren mining district, Idaho County, Idaho: Idaho Bureau of Mines and Geology Pamphlet, 65 p.

Rehn, W.R., and Lund, K., 1981, Eocene extensional plutonism in the Idaho batholith region: Geological Society of America Abstracts with Programs, v. 13, p. 536.

Reidel, S.P., 1983, Stratigraphy and petrogenesis of the Grande Ronde Basalt from the deep canyon country of Washington, Oregon, and Idaho: Geological Society of America Bulletin, v. 94, p. 519-542.
Ross, C.P., 1925, The copper deposits near Salmon, Idaho: U.S. Geological Survey Bulletin, 44 p.

Ross, C.P., 1933, The Thunder Mountain mining district, Valley County, Idaho: Economic Geology, v. 28, p. 587-601.

Ross, C.P., 1934, Geology and ore deposits of the Casto quadrangle, Idaho: U.S. Geological Survey Bulletin, p. 135.

Ross, C.P., 1947, Geology of the Borah Peak quadrangle, Idaho: Geological Society of America Bulletin, v. 58, p. 1085-1160.

Ross, C.P., 1962, Paleozoic seas of central Idaho: Geological Society of America Bulletin, v. 73, p. 769-794.

Ross, C.P., and Forrester, J.R., 1947, Geologic map of the State of Idaho: U.S. Geological Survey and Idaho Bureau of Mines and Geology, scale 1:500,000.

Ross, G.M., Bloch, J.D., and Krouse, H.R., 1995, Neoproterozoic strata of the southern Canadian Cordillera and the isotopic evolution of seawater sulfate: Precambrian Research, v. 73, p. 71-99.

Ross, G.M., McMechan, M.E., and Hein, F.J., 1989, Proterozoic history-The birth of the miogeocline, in Ricketts, B.D., eds., Western Canada sedimentary basin-A case history: Calgary, Alberta, Canadian Society of Petroleum Geologists, p. 79-104.

Ruppel, E.T., 1975, Precambrian Y sedimentary rocks in east-central Idaho: U.S. Geological Survey Professional Paper 889-A, 23 p.

Saint Blanquat, M., Tikoff, B., Teyssier, C., and Vigneresse, J.L., 1998, Transpressional kinematics and magmatic arcs, in Holdsworth, R.E., Strachan, R.A., and Dewey, J.F., eds., Continental transpressional and transtensional tectonics: London, Geological Society of London, Special Publication 135 , p. 327-340.

Saleeby, J., 1981, Ocean floor accretion and volcanoplutonic arc evolution of the Mesozoic Sierra Nevada, in Ernst, W.G., ed., The geotectonic development of California: Englewood Cliffs, N.J., Prentice-Hall, Rubey Volume I, p. 132-181.

Schmidt, D.L., 1964, Reconnaissance petrographic cross section of the Idaho batholith in Adams and Valley Counties, Idaho: U.S. Geological Survey Bulletin 1181-G, 50 p.

Schmidt, D.L., and Mackin, J.H., 1970, Quaternary geology of Long and Bear Valleys, west-central Idaho: U.S. Geological Survey Bulletin 1311-A, 22 p.

Schmidt, K.L., Lewis, R.S., Burmester, R.F., and Lang, R.A., 1994, Reconnaisance geologic map of the Shoup and Horse Creek area, Lemhi County, Idaho: Idaho Geological Survey Technical Report 94-3, scale 1:50,000. 
Schrader, F.C., and Ross, C.P., 1926, Antimony and quicksilver deposits in the Yellow Pine district, Idaho: U.S. Geological Survey Bulletin 780-D, p. 137-164.

Selverstone, J., Wernicke, B.P., and Aliberti, E.A., 1992, Intracontinental subduction and hinged unroofing along the Salmon River suture zone, west central Idaho: Tectonics, v. 11, p. 124-144.

Shannon, S.S., Jr., and Reynolds, S.J., 1975, A brief geological survey of the East Thunder Mountain mining district, Valley Co., Idaho: Idaho Bureau of Mines and Geology Information Circular 29, 13 p.

Shenon, P.J., and Ross, C.P., 1936, Geology and ore deposits near Edwardsburg and Thunder Mountain, Idaho: Idaho Bureau of Mines and Geology Pamphlet 44, 45 p.

Shockey, P.N., 1957, Reconnaissance geology of the Leesburg quadrangle, Lemhi County, Idaho: Idaho Bureau of Mines and Geology Pamphlet, $42 \mathrm{p}$.

Silberling, N.J., Jones, D.L., Blake, M.C., Jr., and Howell, D.G., 1984, Lithotectonic terrane map of the western conterminous United States, in Silberling, N.J., and Jones, D.L., eds., Lithotectonic terrane maps of the North American Cordillera: U.S. Geological Survey Open-File Report 84-523, p. C1-C32.

Silberling, N.J., Jones, D.L., Monger, J.W.H., and Coney, P.J., 1992, Lithotectonic terrane map of the North American Cordillera: U.S. Geological Survey Miscellaneous Investigations Series Map I-2176, scale 1:5,000,000.

Skurla, S.J., 1974, The geology of the Sturgill Peak area, Washington County, Idaho: Corvallis, Oreg., Oregon State University Master's thesis, $98 \mathrm{p}$.

Slater, M.N., 1969, Geology and mineral deposits of the western Cuddy Mountain district, western Idaho: Corvallis, Oreg., Oregon State University Master's thesis, 82 p.

Smitherman, J.R., 1985, Geology of the Stibnite roof pendant, Valley County, Idaho: Moscow, Idaho, University of Idaho M.S. thesis, $62 \mathrm{p}$.

Snee, L.W., Lund, K., Sutter, J.F., Balcer, D.E., and Evans, K.V., 1995, $\mathrm{An}{ }^{40} \mathrm{Ar}{ }^{39} \mathrm{Ar}$ chronicle of the tectonic development of the Salmon River suture zone, western Idaho, in Vallier, T.L., and Brooks, H.C., eds., Geology of the Blue Mountains region of Oregon, Idaho, and WashingtonPetrology and tectonic evolution of pre-Tertiary rocks of the Blue Mountains region: U.S. Geological Survey Professional Paper 1438 p. 517-540.

Spry, P.G., Peter, J.M., and Slack, J.F., 2000, Meta-exhalites as exploration guides to ore, in Spry, P.G., Marshall, B., and Vokes, F.M., eds., Metamorphosed and metamorphogenic ore deposits: Society of Economic Geologists, Reviews in Economic Geology, II, p. 163-202.
Stewart, J.H., 1991, Latest Proterozoic and Cambrian rocks of the western United States-An overview, in Cooper, J.D., and Stevens, C.H., eds., Paleozoic paleogeography of the Western United States; II: Los Angeles, Calif., Pacific Section Society of Economic Paleontologists and Mineralogists, 1, p. 13-38.

Strayer, L.M.I., 1988, Field guide to deformation and sense of displacement in mylonitic rocks near Orofino, Idaho, in Lewis, S.E., and Berg, R.B., eds., Precambrian and Mesozoic plate margins, Montana, Idaho, and Wyoming with field guides for the 8th International Conference on Basement Tectonics: Montana Bureau of Mines and Geology Special Publication, p. 165-169.

Strayer, L.M.I., Hyndman, D.W., Sears, J.W., and Myers, P.E., 1989, Direction and shear sense during suturing of the Seven Devils-Wallowa terrane against North America in western Idaho: Geology, v. 17, p. 1025-1028.

Swanson, D.A., Wright, T.L., Hooper, P.R., and Bentley, R.D., 1979, Revisions in stratigraphic nomenclature of the Columbia River Basalt Group: U.S. Geological Survey Bulletin 1457-G, 59 p.

Sylvester, A.G., and Smith, R.R., 1976, Tectonic transpression and basement-controlled deformation in San Andreas fault zone, Salton trough, California: American Association of Petroleum Geologists Bulletin, v. 60, p. 2081-2102.

Sylvester, A.G., 1988, Strike-slip faults: Geological Society of America Bulletin, v. 100, p. 1666-1703.

Tikoff, B., Kelso, P., Manduca, C., Markley, M.J., and Gillaspy, J., 2001, Lithospheric and crustal reactivation of an ancient plate boundary-The assembly and disassembly of the Salmon River suture zone, Idaho, USA, in Holdsworth, R.E., Strachan, R.A., Magloughlin, J.F., and Knipe, R.J., eds., The nature and tectonic significance of fault zone weakening: London, Geological Society of London, Special Publications 186, p. 213-231.

Tikoff, B., and Manduca, C., 1997, Late Cretaceous dextral transpressional shearing in the Idaho suture zone: Geological Society of America Abstracts with Programs, v. 29, no. 5, p. 70.

Toth, M.I., 1983, Reconnaissance geologic map of the Selway-Bitterroot Wilderness, Idaho County, Idaho, and Missoula and Ravalli Counties, Montana: U.S. Geological Survey Miscellaneous Field Studies Map MF-1495-B, scale 1:250,000.

Tysdal, R.G., 2000, Revision of Middle Proterozoic Yellowjacket Formation, central Idaho: U.S. Geological Survey Professional Paper 1601-A, 13 p. 
Tysdal, R.G., Evans, K.V., and Lund, K., 2000, Geologic map of the Blackbird Mountain quadrangle, Lemhi County, Idaho: U.S. Geological Survey Geologic Investigations Series I-2728, scale 1:24,000.

Tysdal, R.G., Lund, K., and Evans, K.V., 2003, Geologic map of the west half of the Salmon National Forest, in Evans, K.V., and Green, G., compilers., Geologic map of the Salmon National Forest and vicinity, east-central Idaho: U.S. Geological Survey Geologic Investigations Series I-2765, scale 1:100,000.

Umpleby, J.B., 1913, Geology and ore deposits of Lemhi County, Idaho: U.S. Geological Survey Bulletin 528, 182 p.

Vallier, T.L., 1967, The geology of part of the Snake River canyon and adjacent areas in northeastern Oregon and western Idaho: Corvallis, Oreg., Oregon State University Ph.D. dissertation, $267 \mathrm{p}$.

Vallier, T.L., 1977, The Permian and Triassic Seven Devils Group, western Idaho and northeastern Oregon: U.S. Geological Survey Bulletin 1437, 58 p.

Vallier, T.L., 1995, Petrology of pre-Tertiary igneous rocks in the Blue Mountains Province of Oregon, Idaho, and Washington-Implications for the geologic evolution of a complex island arc, in Vallier, T.L., and Brooks, H., eds., Geology of the Blue Mountains region of Oregon, Idaho, and Washington-Petrology, stratigraphy, tectonics, and resources: U.S. Geological Survey Professional Paper 1438, p. $125-210$.

Vandenburg, C.J., and Janecke, S.U., 1998, Three-dimensional strain produced by $>50 \mathrm{~m}$.y. of episodic extension, Horse Prairie basin area, SW Montana, U.S.A.: Journal of Structural Geology, v. 20, p. 1747-1767.

Walker, N.W., 1982, Pre-Tertiary plutonic rocks in the Snake River canyon, Oregon/Idaho-Intrusive roots of a Permo-Triassic arc complex: Geological Society of America Abstracts with Programs, v. 14, no. 4, p. 242-243.

Walker, N.W., 1986, U/Pb geochronologic and petrologic studies in the Blue Mountains terrane, northeastern Oregon and westernmost-central Idaho-Implications for pre-Tertiary tectonic evolution: Santa Barbara, Calif., University of California Ph.D. dissertation, 214 p.
Walker, N.W., 1989, Early Cretaceous initiation of post-tectonic plutonism and the age of the Connor Creek fault, northeastern Oregon: Geological Society of America Abstracts with Programs, v. 21, no. 5, p. 155.

Walker, N.W., 1995, Tectonic implications of U-Pb zircon ages of the Canyon Mountain Complex, Sparta complex, and related metaplutonic rocks of the Baker terrane, northeastern Oregon, in Vallier, T.L., and Brooks, H.C., eds., Geology of the Blue Mountains region of Oregon, Idaho, and Washington-Petrology and tectonic evolution of pre-Tertiary rocks of the Blue Mountains region: U.S. Geological Survey Professional Paper 1438, p. 247-270.

Watts, K.C., Jr., and King, H.D., 1999, Geochemistry of the forest, Idaho: U.S. Geological Survey Open-File Report 98-219-E, 44 p.

Weis, P.L., Schmitt, L.J., Jr., and Tuchek, E.T., 1972, Mineral resources of the Salmon River Breaks Primitive Area, Idaho: U.S. Geological Survey Bulletin 1353-C, 91 p.

White, D.E., 1941, Geologic map of the Yellow Pine area, Valley County, Idaho: U.S. Geological Survey Strategic Minerals Investigations Preliminary Map, scale 1:48,000.

White, J.D.L., White, D.L., Vallier, T.L., Stanley, G.D., Jr., and Ash, S.R., 1992, Middle Jurassic strata link Wallowa, Olds Ferry, and Izee terranes in the accreted Blue Mountains island arc, northeastern Oregon: Geology, v. 20, p. 729-732.

White, W.H., 1968, Plutonic rocks of the southern Seven Devils Mountains, Idaho: Corvallis, Oreg., Oregon State University Ph.D. dissertation, 177 p.

White, W.H., 1973, Flow structure and form of the Deep Creek stock, southern Seven Devils Mountains, Idaho: Geological Society of America Bulletin, v. 84, p. 199-210.

Wracher, D.A., 1969, The geology and mineralization of the Peck Mountain area, Hornet quadrangle, Idaho: Corvallis, Oreg., Oregon State University Master's thesis, 78 p.

Zen, E., 1985, Implications of magmatic epidote-bearing plutons on crustal evolution in the accreted terranes of northwestern North America: Geology, v. 13, p. 266-269. 


\section{Description of Map Units for the Geologic Map of the Payette National Forest, West-Central Idaho}

By Karen Lund

Chapter B of

Geology of the Payette National Forest and Vicinity, West-Central Idaho

By Karen Lund

Professional Paper 1666-B

Version 1.1, April 2021

Supersedes USGS Miscellaneous Geologic Investigations Map I-2599 and the GIS data in USGS Open-File Report 98-219-B 



\section{Contents}

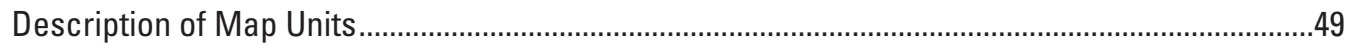

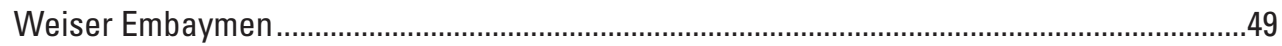

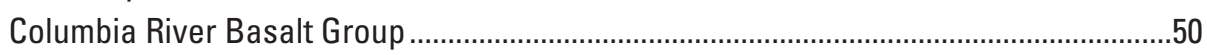

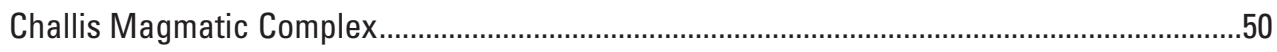

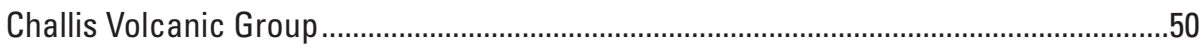

Thunder Mountain caldera .................................................................................50

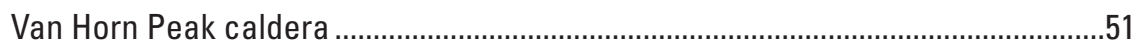

Hypabyssal intrusive rocks ...................................................................................

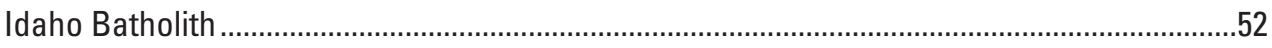

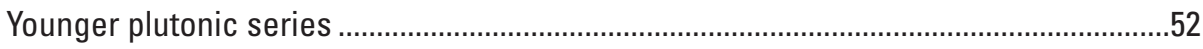

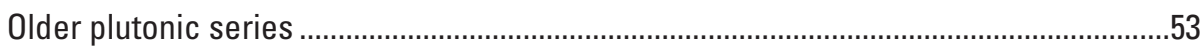

Salmon River Suture Complex ...............................................................................................

Allochthonous Rocks of Blue Mountains Island Arc ……......................................................54

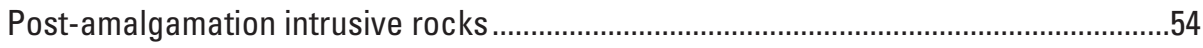

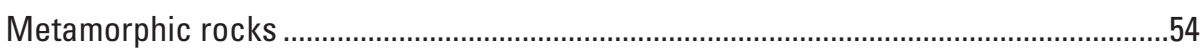

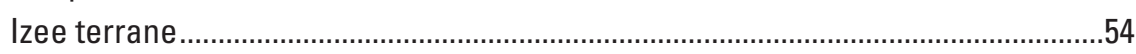

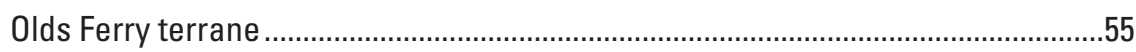

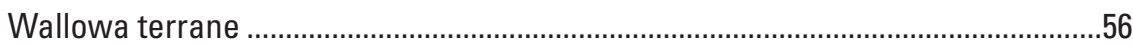

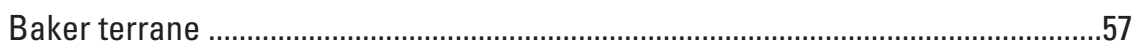

High-grade metamorphic and plutonic rocks, terrane unknown ..................................57

Laurentian Continental Rocks...............................................................................5

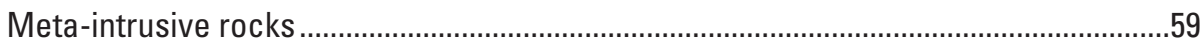

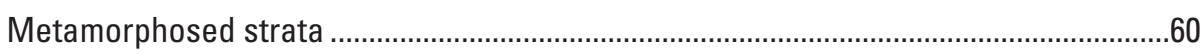

High-grade metamorphic units...........................................................................64

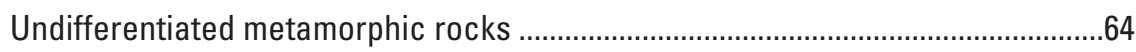

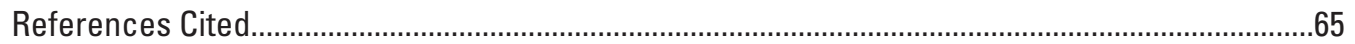

\section{Figures}

B1-B21. Photographs of:

B1. Eocene pink hornblende-biotite granite porphyry …………………………............69

B2. Eocene pink hornblende-biotite syenogranite ……….........................................69

B3. Rainbow arch cut in typical outcrops of Late Cretaceous

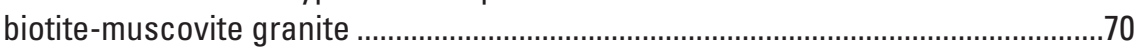

B4. Late Cretaceous porphyritic biotite granodiorit .....................................................71

B5. Cretaceous gneissic coarse-grained hornblende tonalite gneiss ...........................72

B6. Heterogeneous mixture of Jurassic to Permian island-arc volcanic rocks and Cretaceous to Jurassic intrusive rocks .........................................................73

B7. Deformed Jurassic to Permian amphibolite and garnet amphibolite gneiss ..........74

B8. Contact between Mesoproterozoic granitic augen gneiss and Mesoproterozoic migmatitic gneiss ....................................................................75

B9. Mesoproterozoic granitic augen gneiss as pluton and as stringers and veins forming in and crosscutting Mesoproterozoic biotite gneiss. 
B10. Cambrian to Neoproterozoic gray marble.

B11 Cambrian(?) and Neoproterozoic quartzite and quartzite conglomerate of Umbrella Butte Formation ...........................................................................................

B12 Neoproterozoic Missouri Ridge Formation …………….........................................8

B13. Neoproterozoic Moores Lake Formation.................................................................

B14. Neoproterozoic Goldman Cut Formation ..........................................................83

B15. Interbedded marble, iron-formation, and metasiltite of Neoproterozoic Moores Station Formation.

B16. Neoproterozoic metavolcanic rocks, metavolcanogenic sedimentary rocks, and diamictites of Edwardsburg Formation. .84

B17. Neoproterozoic Square Mountain Formation. .85

B18. Mesoproterozoic biotite-feldspar-quartz metasandstone of Gunsight Formation

B19. Mesoproterozoic laminated biotite phyllite and fine-grained metasandstone to siltite of Apple Creek Formation...

B20. Mesoproterozoic metasandstone and quartzite of Hoodoo Quartzite ....................88

B21. Mesoproterozoic Yellowjacket Formation .................................................................89 


\title{
Description of Map Units for the Geologic Map of the Payette National Forest, West-Central Idaho
}

\author{
By Karen Lund
}

\section{DESCRIPTION OF MAP UNITS}

\begin{abstract}
[The purpose of this chapter is to provide rock unit descriptions for the geologic maps of the western and eastern parts of the Payette National Forest, which includes parts of Valley, Idaho, Washington, Adams, Gem, and Custer Counties in west-central Idaho. The geologic setting and interpretation of the units and their metamorphic and structural history are provided in Chapter A. Igneous rocks and metamorphosed igneous rocks are classified according to modal analysis of the minerals present (Streckeisen, 1973). Textural features are also used to discriminate some units. Common mafic minerals are listed in order of increasing abundance from least to most abundant. Metamorphic rocks are described in terms of their composition, layering features, and mineralogy. Important minerals in the metamorphic rocks are listed in order of abundance as for the igneous rocks]
\end{abstract}

Qu Alluvial, landslide, and glacial deposits (Quaternary) - Unconsolidated boulder, gravel, sand, clay, and peat deposits of Holocene and Pleistocene age. These include moraine, glacial outwash, stream, talus, and landslide deposits. Four glacial episodes, pre-Bull Lake, Bull Lake (Blm on pl. 1), Pinedale (Pm on pl. 1), and Neoglaciation, are recognized in some areas based on outwash terraces and moraines

\section{WEISER EMBAYMENT}

QTi Idaho Group (Pleistocene and Pliocene) — Arkosic sedimentary rocks found along southern margin of Weiser embayment (pl. 1; fig. A3) and along fault troughs in Long Valley area (southeastern pl. 1 and southwestern pl. 2). Postdates basalts of Weiser embayment

Tp Payette Formation (Miocene) - Thin discontinuous soil horizons as well as ash beds and locally derived sediments deposited as interbeds and in local basins. Those interbedded with Imnaha (Tcri) and Grande Ronde (Tcrg) Basalts are considered to be lower part of Payette Formation whereas those associated with basalt of Weiser (Tw) are considered to be upper part of Payette Formation (Fitzgerald, 1982)

Tw Basalt of Weiser (Miocene) — Basalt flows that are post-Grande Ronde Basalt (Tcrg) and areally restricted to south-central part of plate 1 . Includes three members and several local units based on stratigraphy, geochemistry, and paleomagnetism (Fitzgerald, 1982). Locally includes interbedded pyroclastic deposits of Weiser (Twp)

Twp Pyroclastic deposits of Weiser (Miocene)_Voluminous pyroclastic materials including pumice breccia, scoria, volcaniclastic debris, and ash; closely related to basalt of Weiser (Tw). Pyroclastic rocks are particularly important near vent areas southeast of Cambridge and south of Midvale (southern pl. 1; Fitzgerald, 1982) where mapped separately from basalt of Weiser (Tw)

Tcm Basalt of Cuddy Mountain (Miocene) - Slightly to highly porphyritic (phyric) basalt flows; coarse pyroxene and plagioclase phenocrysts. Restricted to eastern edge of Cuddy Mountain uplift (west-central pl. 1). Mostly deposited on pre-Tertiary rocks of uplift. On southwestern part of Cuddy Mountain, a lower flow of basalt of Cuddy Mountain is overlain by a Grande Ronde Basalt (Tcrg) flow; elsewhere, an upper flow of unit Tcm may overlie unit Tcrg (not shown on map; Fitzgerald, 1982). Unit Tcm may at least span the time of deposition of unit Tcrg (Fitzgerald, 1982) but unit Tcm has also been included with basalt of Weiser (Tw) and correlated with the Strawberry Volcanics of Oregon (Hooper and Swanson, 1990) 
Columbia River Basalt Group

Tcr Columbia River Basalt Group, undivided (Miocene) - Includes Grande Ronde and Imnaha Basalts (Tcrg and Tcri, respectively) where they have not been mapped separately (mostly northern pl. 1). Exposures are part of eastern fringe of Columbia River Plateau known as the Weiser embayment (fig. A3, pl. 1; Fitzgerald, 1982). Faulting and erosion have caused discontinuous exposures that are remnants of more complete basalt cover to the west

Tcrg Grande Ronde Basalt-Nonporphyritic (aphyric) basalt; fine plagioclase laths in some flows. Sugary texture. Medium dark gray. Some green mottling on fresh surfaces at tops of flows; weathered tops of flows are reddish gray. Flows are 10-20 m thick. Total thickness in Weiser embayment (fig. A3) is less than $300 \mathrm{~m}$ (Fitzgerald, 1982). Flows are geochemically homogeneous and are subdivided based on paleomagnetism (Swanson and others, 1979). Deposited conformably on Imnaha Basalt (Tcri). Age 16.5-15.6 Ma (Long and Duncan, 1982)

Imnaha Basalt - Coarsely porphyritic (phyric) basalt flows at base of Columbia River Basalt Group. Phenocrysts are plagioclase, olivine, and augite. Black, except tops of some flows are purplish gray. Flows are 20-60 m thick; as many as 19 flows are exposed in areas in and near the forest. Total thickness at least $700 \mathrm{~m}$ in the Weiser embayment (fig. A3; Fitzgerald, 1982). Age 17.5-16.5 Ma (McKee and others, 1981)

\section{CHALLIS MAGMATIC COMPLEX}

Challis Volcanic Group

\section{Thunder Mountain caldera}

Tc
Challis Volcanic Group, undivided (Eocene) - Dacitic to rhyolitic ash flows and lahars and minor volcaniclastic sedimentary rocks (Cater and others, 1973; Fisher and others, 1992) in northern half of Thunder Mountain caldera (fig. A3; central pl. 2, north of lat $45^{\circ} \mathrm{N}$.), which remains mapped only at reconnaissance level as of 2003. Based on extension of units from areas mapped in greater detail in southern part of caldera, the lower part of the informal Sunnyside tuff (Tcs), buff rhyolite (Tcbr), and lapilli tuff (Tct) are probably the major units in northern, unsubdivided part of caldera. In northwestern part of caldera, exposed rocks are predominantly basal lahar units containing at least 25 percent prevolcanic metamorphic and igneous cobbles. Samples from this area have been preliminarily K-Ar dated at about 48-51 Ma (Leonard and Marvin, 1982)

Latite of Lookout Mountain-Black, nearly aphyric, vesicular latite lava containing cinder layers and volcanic bombs. Thickness $0-50 \mathrm{~m}$. Located in central part of caldera complex near Sunnyside mine (central pl. 2, between Dewey and Venable mines; Fisher and others,

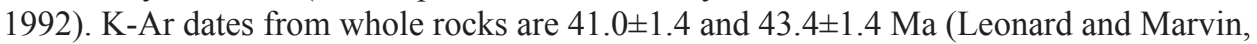
1982)

Volcaniclastic rocks of Dewey mine - Caldera-filling sedimentary rocks. Includes bedded volcaniclastic ash, varved lake-bed siltstone, volcaniclastic conglomerate, talus, and landslide deposits. Gold in hydrothermal system at Dewey mine (central pl. 2; Ross, 1933) chemically fixed by carbonaceous debris in unit

Sunnyside tuff - Complex informal rhyolitic unit making up most of southern Thunder Mountain caldera complex (fig. A3; central pl. 2) as subdivided by Fisher and others (1992). Upper part of Sunnyside tuff is a multiple-flow, compound cooling unit of red-weathering, densely welded, devitrified rhyolite tuff; contains rock fragments and flattened pumice lapilli; black vitrophyric base. Upper and lower parts of unit separated by megabreccia unit wherein fragments from lower part of unit are included in matrix of tuff from upper part of unit. Megabreccia may have formed from collapse of caldera walls at beginning of eruption of tuffs of upper part of unit. Lower part of Sunnyside tuff, from bottom to top, is (1) three or more cooling units of white to pink, only slightly welded, pumice-bearing, slightly porphyritic rhyolite bases and gray, vertically jointed, densely welded, phenocryst-rich (as much as 50 percent) quartz latite tops; (2) at least two cooling units of red, flow-layered lava or hot ash- 
flow tuff with black vitrophyre and intercalated black vesicular latite flow; and (3) a single cooling unit of reddish-gray, densely welded rhyolite tuff. Thickness as much as $1,000 \mathrm{~m}$ (Fisher and others, 1992). Originally named in Thunder Mountain mining district (fig. A4; Shannon and Reynolds, 1975). Biotite K-Ar date of $47.7 \pm 1.6 \mathrm{Ma}$ and sanidine K-Ar dates on two samples of $46.3 \pm 1.1$ and $46.3 \pm 1.0$ (Leonard and Marvin, 1982)

Tcbr Buff rhyolite - Nearly aphyric buff rhyolite. Flow laminated and layered. Thickness 0-300 m. In same stratigraphic position on western margin of caldera complex as lapilli tuff (Tct) is around southern and eastern margins (Fisher and others, 1992)

Tcp Perlitic rhyolite-Rhyolite ash-flow tuffs; three recognized cooling units (Fisher and others, 1992). Finely porphyritic rhyolite; plagioclase phenocrysts, less than $2 \mathrm{~mm}$ long, form 14 percent of unit. Cooling units have black vitrophyric bases, lavender to salmon devitrified or densely welded tops, and green epiclastic sedimentary rocks as interbeds. Thickness 0-300 m. Forms thin unit in central part of caldera (Fisher and others, 1992)

Lapilli tuff-Complex unit of lapilli-bearing ash-flow latite tuff, tuffaceous sedimentary rocks, and black latite lava. Greenish-gray or buff lapilli latite tuff is densely welded; contains plagioclase and pyroxene phenocrysts and conspicuous dark-green, 1.5- to 2.5-cm-long, collapsed pumice lapilli. Ash-flow tuffs are interbedded with tuffaceous sandstone and siltstone. Thin unit of black latite is a local interbed. Quartz-rich, densely welded, gray tuff forms base of unit on southwest side of caldera. Thickness 0-500 $\mathrm{m}$. Unit has undergone pervasive propylitic alteration. Eruption of unit caused initial collapse of Thunder Mountain caldera (Fisher and others, 1992)

Tcll Lower latite lava - Dark-gray and dark-purplish-gray, flow-layered latite lava. Latite lava is crystal poor and layered with porphyritic dacite-rhyolite flows having plagioclase, biotite, hornblende, and pyroxene phenocrysts. Thickness $0-500 \mathrm{~m}$. Found on fringes of Thunder Mountain caldera (Fisher and others, 1992). Sanidine K-Ar age of 50.8 $\pm 1.7 \mathrm{Ma}$ (Leonard and Marvin, 1982)

\section{Van Horn Peak caldera}

Tuff of Ellis Creek - Crystal-rich, grayish-green, rhyodacite ash-flow tuff. Subequal amounts of plagioclase, resorbed quartz, biotite, and hornblende phenocrysts. Pumice lapilli common. Two outflow units recognized. Thickness in forest unknown, but as much as $2,000 \mathrm{~m}$ in localities to the east. Unit formed as outflow from Van Horn Peak caldera on east side of Middle Fork of Salmon River (directly east of pl. 2). Biotite K-Ar date of 48.4 $\pm 1.6 \mathrm{Ma}$ (Fisher and others, 1992)

\section{Hypabyssal intrusive rocks}

Porphyritic rhyolite to dacite dikes and plugs (Eocene) - Porphyritic rhyolite to dacite and coarser grained granite porphyry to hornblende-biotite granodiorite. Dikes are 1-100 m wide and structurally controlled. Most intense concentration is Profile Gap-Smith Creek dike swarm (Lund and others, 1997); average strike about N. $10^{\circ}$ E. First mapped at Profile Gap (central pl. 2) by Shenon and Ross (1936) where intruded into Profile Gap-Johnson Creek shear zone (Lund and others, 1997). Dikes are dated by K-Ar on hornblende at about 46-47 Ma (Leonard and Marvin, 1982). These rocks also make up the areally larger Pistol Creek dike swarm (south-central pl. 2; Fisher and others, 1992), which has similar north-northeast trend. They also form the Rainbow Ridge dike swarm and the dikes near Van Meter Hill (3 km northwest of Yellow Pine, central pl. 2), which trend about N. $65^{\circ}$ E. and are primarily formed of hornblende-biotite granodiorite and porphyritic dacite, respectively

Tgp Granite porphyry and minor rhyolite porphyry (Eocene) - Consists of several textural varieties, which are not differentiated on map: (1) Green rhyolite; aphanitic groundmass has as much as 50 percent quartz and feldspar phenocrysts. (2) Light-tannish-pink, miarolitic rhyolite porphyry; quartz and potassium feldspar phenocrysts and aphanitic groundmass of the same mineralogic composition. (3) Tannish-pink syenogranite porphyry (fig. B1); finegrained groundmass and as much as 75 percent fine- to medium-grained quartz, potassium feldspar, biotite, and hornblende phenocrysts; also as much as 20 percent miarolitic cavities, 
some lined with bipyramidally terminated quartz crystals. (4) Gray monzogranite porphyry; fine-grained groundmass; common plagioclase phenocrysts; lesser amounts of potassium feldspar, biotite, and hornblende; and minor quartz phenocrysts.

Forms core of Savage Point pluton (fig. A3; Lund and others, 1997) along east-west trend from Rock Lake to upper Logan Creek (central pl. 2). Crops out in Wolf Fang Peak area as southwestern arm of roof zone of Chamberlain Basin pluton (fig. A3; north-central pl. 2). Rocks of this composition form part of Rainbow Ridge dike swarm (central pl. 2). Unit also present in roof areas of Casto pluton (fig. A3) and intruding Challis Volcanic Group in southeast corner of plate 2

Tg Hornblende-biotite granite (Eocene) - Composed of two compositional varieties, both common in Eocene plutons of central Idaho. (1) Tannish-pink, equigranular, medium- to coarse-grained hornblende-biotite syenogranite (fig. B2) forms much of Casto pluton, western part of Chamberlain Basin pluton, and easternmost phase of Chamberlain Basin pluton (fig. A3) known as Bighorn Crags pluton (eastern pl. 2). (2) Light-gray, porphyritic, medium-grained hornblende-biotite monzogranite; contains less hornblende than syenogranite and forms major part of Chamberlain Basin, Savage Point, and Casto plutons

Tgd Fine-grained hornblende-biotite granodiorite (Eocene) - Light-gray, fine-grained hornblende-biotite granodiorite. Forms early phase of Eocene plutons intruded by and fringing the granites ( $\mathrm{Tg}$ ) in Savage Point, Chamberlain Basin, and Casto plutons (fig. A3). Rocks of this composition also form major part of unit Tpr in Rainbow Ridge dike swarm (Lund and others, 1997)

Diorite (Eocene) - Dark-brownish-gray, medium-grained hornblende-biotite diorite. Coarsegrained, strongly zoned plagioclase; medium- to coarse-grained hornblende and biotite; and dark, fine-grained felted masses of plagioclase, quartz, hornblende, biotite, and opaque minerals as groundmass. Forms oldest phase of Eocene intrusions in Casto pluton (Fisher and others, 1992) and in western part of Chamberlain Basin pluton (fig. A3)

\section{IDAHO BATHOLITH}

\section{Younger plutonic series}

Kg Biotite-muscovite granite (Late Cretaceous) - Gray, medium-grained biotite-muscovite granite (fig. B3). Muscovite equal to biotite or more abundant. Rock is equigranular and minerals are subhedral. Structurally homogeneous (nonfoliated) texture. Pegmatite zone commonly observed at roof of unit Kg near contact with unit Kpg. Unit dated by $\mathrm{U}-\mathrm{Pb}$ zircon at $82 \pm 1 \mathrm{Ma}$ at Chimney Rock (center pl. 2; K. Lund, J.N. Aleinikoff, and D.M. Unruh, unpub. data, 2002). Crosscutting relationships not found; however, map relations (central pl. 2) suggest unit Kg intruded unit Kpg, and a fluid-rich pegmatite zone at the roof of $\mathrm{Kg}$ also indicates $\mathrm{Kg}$ is the younger

Kpg Porphyritic muscovite-biotite granite-granodiorite (Late Cretaceous) - Consists of varieties of gray porphyritic muscovite-biotite granite-granodiorite, gray biotite granitegranodiorite, and gray muscovite-biotite granite. In porphyritic variety, potassium feldspar phenocrysts, generally about $1 \mathrm{~cm}$ long, range from very common (15 percent) to sparse $(<1$ percent). In nonporphyritic varieties, minerals are medium grained and subhedral. Quartz grains form fine-grained aggregates. Muscovite varies from trace amounts to subequal with biotite, and increases near the contact with the younger biotite-muscovite granite $(\mathrm{Kg})$; some muscovite may be secondary. Monazite and xenotime are common accessory minerals and are ubiquitous heavy minerals in placers in Warren mining district (fig. A4). In western exposures, foliation is present but is inconsistently oriented; in eastern exposures, texture is nonfoliated. Unit dated by U-Pb zircon at $79 \pm 1$ Ma near mouth of East Fork South Fork Salmon River (center pl. 2) and near Paddy Flat (southeast pl. 2) and at $85 \pm 2 \mathrm{Ma}$ in Buffalo Hump mining district (north-central pl. 2; K. Lund, J.N. Aleinikoff, and D.M. Unruh, unpub. data, 2002). Muscovite-bearing varieties may be equivalent to Warm Lake quartz monzonite but much of unit Kpg is probably equivalent to Gold Fork granodiorite (Schmidt, 1957) 
Older plutonic series

Kgdf Foliated biotite granodiorite (Late Cretaceous) - Gray, fine- to medium-grained biotite granodiorite. Hornblende may be present in trace amounts. Local plagioclase phenocrysts. Prominent foliation formed by planar alignment of biotite and locally by flattening of quartz. Local biotite lineation. Inclusions, schlieren, and screens of country rock are common. Foliated biotite granodiorite is closely associated with foliated tonalite (Ktf) near Salmon River suture (fig. A3; eastern pl. 1 and western pl. 2) and at roof of Idaho batholith on plate 2. Equivalent to Little Valley quartz diorite of Schmidt (1957)

Ktf

Foliated hornblende-biotite tonalite (Late Cretaceous) - Gray, medium-grained, foliated and commonly lineated hornblende-biotite tonalite. Hornblende generally subsidiary to biotite; abundance of each ranges from trace to 10 percent. Primary epidote common (Manduca, 1988). Foliation formed by planar alignment of biotite flakes and elongation and flattening of quartz grains. Lineation formed by orientation of elongate hornblende grains. Schlieren and screens of metamorphic country rock are common near Salmon River suture (eastern pl. 1 and western pl. 2). Also preserved at top of Idaho batholith in isolated locations on plate 2 where intruded by units $\mathrm{Kg}$ and $\mathrm{Kpg}$. Dated by $\mathrm{U}-\mathrm{Pb}$ zircon at $89 \pm 1 \mathrm{Ma}$ from north of Payette Lake (west-central pl. 2) and 89 2 Ma in Buffalo Hump mining district (northern edge pl. 2; K. Lund, J.N. Aleinikoff, and D.M. Unruh, unpub. data, 2002). Equivalent to tonalite of Payette River of Manduca (1988) and probably equivalent to quartz dioritic gneiss of Donnelly of Schmidt (1957)

Kpgdf Foliated porphyritic biotite granodiorite (Late Cretaceous) - Coarsely porphyritic hornblende-biotite granodiorite; large pink potassium feldspar phenocrysts (fig. B4). More mafic than other Cretaceous granite and granodiorite (Kgdf or Kpg), having as much as 15 percent mafic minerals. Foliation common. Unit dated by U-Pb zircon at about $91 \mathrm{Ma}$ from upper Johnson Creek (south-central pl. 2; K. Lund and D.M. Unruh, unpub. data, 2002). Previous K-Ar date of 75-81 Ma on biotite from same locality (Fisher and others, 1992) probably reflects regional cooling. Intruded by units $\mathrm{Kg}$ and $\mathrm{Kpg}$; crosscutting relationships with units Ktf and Kgdf unknown

\section{SALMON RIVER SUTURE COMPLEX}

Kpgdm Gneissic porphyritic biotite granodiorite (Early Cretaceous) - Porphyritic biotite granodiorite gneiss; coarse phenocrysts of microcline in medium-grained quartzplagioclase-microcline-biotite groundmass; 5-15 percent biotite. Fabric ranges from foliated porphyritic granodiorite to mylonitic augen gneiss. Dated by SHRIMP U-Pb zircon at $115 \pm 1 \mathrm{Ma}$ from along Little Goose Creek (west edge pl. 2; K. Lund, J.N. Aleinikoff, and D.M. Unruh, unpub. data, 2002; previously dated at $111 \pm 5 \mathrm{Ma}$, Manduca, 1988). Equivalent to porphyritic orthogneiss that forms part of Little Goose Creek Complex (Manduca and others, 1993). Only differentiated from heterogeneous orthogneiss complex (Kgn) in large unmixed body forming much of West Mountains (east-central pl. 1)

Kgn Heterogeneous orthogneiss complex (Early Cretaceous) - Coarse-grained hornblende tonalite gneiss, porphyritic granodiorite gneiss (probably same rock as unit Kpgdm), and medium-grained biotite granodiorite gneiss (eastern pl. 1). Rocks are strongly deformed together (fig. B5) such that they cannot be mapped separately at this scale (for detail, see Manduca, 1988). Equivalent to Little Goose Creek Complex of Manduca and others (1993), gneissic quartz monzonite and quartz diorite unit of Hamilton (1969), and part of migmatite of McCall of Schmidt (1957) 


\section{ALLOCHTHONOUS ROCKS OF BLUE MOUNTAINS ISLAND ARC}

Post-amalgamation intrusive rocks

KJqd Quartz diorite and tonalite (Early Cretaceous? and Late Jurassic) - Hornblende quartz diorite and tonalite of Deep Creek and Echols Mountain plutons, nearby unnamed plutons (Cannon and others in Hamilton, 1963; White, 1968, 1973; G.C. Simmons, USGS, unpub. data, 1980; Aliberti, 1988; north-central pl. 1), and unnamed pluton in lower Rapid River (Hamilton, 1963; Onasch, 1977; G.C. Simmons, USGS, unpub. data, 1980; Aliberti, 1988; northwestern pl. 1) in the Wallowa terrane. Hornblende K-Ar date of 137 4 Ma on Deep Creek pluton (Armstrong and others, 1977; recalculated by Walker, 1986) and hornblende

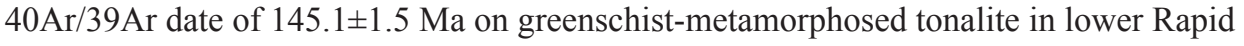
River (Snee and others, 1995) probably represent minimum age of emplacement. In southern Seven Devils Mountains, this group of plutons intruded the Wallowa terrane across trends of Oxbow-Cuprum shear zone and earlier deformed plutons ( $\mathrm{Pd}$ and Pqd; Cook, 1954; Cannon and others, in Hamilton, 1963; White, 1968, 1973; Gualtieri and Simmons, 1978; Vallier, 1995). Previously interpreted to have intruded as funnel-shaped bodies. Foliation in plutons parallel to foliation in country rock previously interpreted to be related to intrusive pressures and flow (White, 1968, 1973). However, all three are intruded along faulted contact of Late Triassic Martin Bridge ( $\mathrm{km})$ and Doyle Creek (ksd) Formations (Cook, 1954; Cannon and others, in Hamilton, 1963; Gualtieri and Simmons, 1978; Aliberti, 1988) as sheets and Deep Creek pluton possibly in a synclinal structure (Cook, 1954). Echols Mountain pluton and pluton in lower Rapid River are deformed (Hamilton, 1963), metamorphosed (Hamilton, 1963; Snee and others, 1995), and cut by strands of the Rapid River thrust system (Aliberti, 1988). Foliation in adjacent country rock and in plutons possibly related to syndeformational emplacement. Foliation interpreted to be same age as deformation in Riggins Group (Hamilton, 1963) that was later related to deformation along the Salmon River suture (Lund, 1984); may be related to amalgamation events as inferred by Walker $(1986,1989)$; or may be related to events occurring early in accretionary history. Echols Mounain pluton and pluton in Rapid River area brecciated and chloritized by movement on normal fault reactivations along upper Rapid River

\section{Metamorphic rocks}

Metamorphosed ultramafic rocks (Mesozoic) - Serpentinized melange containing fragments of Baker terrane ( $\mathrm{MzP}_{z} \mathrm{~b}$ ) and Weatherby Formation (Jws) of Izee terrane. Found in Cuddy Mountain fault zone (west-central pl. 1) where Baker and Izee terranes are juxtaposed along east-directed thrust fault. Also found in northeastern part of plate 1 within metamorphosed rocks of the Riggins Group in unit mapped as Squaw Creek Schist (JPrs) (Hamilton, 1963, 1969; Onasch, 1977, 1987)

\section{Izee terrane}

Jws Volcaniclastic rocks of the Weatherby Formation (Jurassic) - Greenstone volcaniclastic rocks and minor latite-andesite tuff of the Weatherby Formation exposed in southwestern part of plate 1 . Volcaniclastic rocks are primarily sandstone and shale containing largely volcanic and chert grains. Sedimentary features such as flute casts, grooves, and finingupward successions indicate deposition by turbidites. Individual andesite tuff (Jwa) and rhyolite tuff (Jwr) members have been mapped separately. Lower part contains several volcanic conglomerate horizons, especially a distinctive red and green conglomerate below rhyolite tuff member (Jwr). Conglomerate matrix is tuffaceous and clasts are predominantly andesite and basalt (Frankhauser, 1969; Bruce, 1971; Henricksen, 1975). Volcanic conglomerates were derived from the Huntington Formation ( $\mathrm{kh}$ ), which, in part unconformably (Slater, 1969; Bruce, 1971) and in part structurally (Livingston, 1932; Skurla, 1974; Henricksen, 1975), underlies the Weatherby Formation. Thus, the Huntington Formation (Olds Ferry terrane) must have been near the Izee terrane during 
the Jurassic. Additionally, the large percentage of chert detritus in sandstones indicates a cherty provenance probably from the Baker terrane, which must have been nearby in the Jurassic as well (Vallier, 1995). Jurassic dates are from fossil assemblages in the unit, particularly ammonite fossils (Brooks, 1979). Thickness greater than 1,300 m (Mann, 1991)

Jwa Andesite tuff-Light-green, greenstone andesite tuff layer in the Weatherby Formation (westcentral pl. 1; Mann, 1991). Composed of weathered plagioclase phenocrysts in a glassy perlitic matrix. Contacts are gradational. Absence of thermal alteration of underlying rocks indicates that andesitic tuff may have formed as a subaqueous ash fall (Mann, 1991). Approximately $130 \mathrm{~m}$ thick (Mann, 1991)

Jwr Rhyolite tuff - Rhyolite to rhyodacite crystal tuff. Traceable across Hitt Mountains and Cuddy Mountain (southwestern pl. 1) above the red and green volcanic conglomerate of the Weatherby Formation. Dated at about 200 Ma by K-Ar methods (C. Field, in Mann, 1989). Thickness 100-230 m (Skurla, 1974)

\section{Olds Ferry terrane}

kgd Porphyritic biotite granodiorite (Late Triassic) — Moderately porphyritic biotite granodiorite; plagioclase phenocrysts as much as $2 \mathrm{~cm}$ long and local quartz phenocrysts; mediumgrained groundmass. Common weak foliation. Intruded the Huntington Formation on Cuddy Mountain. Spatially and genetically related to quartz diorite ( $\mathrm{kqd}$ ) and gabbro ( Kgb), which all crop out on Cuddy Mountain and in the Hitt Mountains (western pl. 1; White, 1968; Frankhauser, 1969; Slater, 1969; Bruce, 1971; King, 1971; Skurla, 1974; Henricksen, 1975); granodiorite is the youngest of these units as demonstrated by crosscutting relationships. Preliminary U-Pb zircon data give age of about $220 \mathrm{Ma}$ for pluton in Cuddy Mountains (D.M. Unruh and K. Lund, unpub. data, 2002). This date indicates that unit kgd is significantly older than, and has a different origin than, the similar looking foliated granodiorite (Kgdf) east of the Salmon River suture. Previous age information was a K-Ar date on hornblende from a sample at Cuddy Mountain of 195-205 Ma (Frankhauser, 1969), which probably indicates regional cooling

kqd Hornblende-biotite quartz diorite (Late Triassic) - Light-gray, medium-grained, equigranular hornblende-biotite quartz diorite. Spatially associated with gabbro ( $\mathrm{kgb}$ ) and granodiorite ( $\mathrm{kgd}$ ) on Cuddy Mountain and in Hitt Mountains where it intruded the Huntington Formation (south-central and southwestern pl. 1, respectively). Previous K-Ar biotite and hornblende dates of 196-225 Ma from plutons on Cuddy Mountain and in Hitt Mountains (Henricksen, 1975)

kgb Hornblende gabbro (Late Triassic) - Medium-gray, medium- to coarse-grained hornblende gabbro plutons (central and southwestern pl. 1). Hornblende is the common mafic mineral in hand specimen; pyroxene and magnetite are common in thin section. Intruded the Huntington Formation on Cuddy Mountain. Intruded by granodiorite ( $\mathrm{kgd}$ ) and quartz diorite ( Kqd) on Cuddy Mountain and in Hitt Mountains (Frankhauser, 1969; Slater, 1969; Bruce, 1971; King, 1971; Skurla, 1974; Henricksen, 1975). Preliminary U-Pb zircon age of about $220 \mathrm{Ma}$ for pluton on northwestern Cuddy Mountain (K. Lund and D.M. Unruh, unpub. data, 2002). K-Ar biotite dates from samples on Cuddy Mountain give an age of 182-197 Ma (Henricksen, 1975), which, being contrary to the crosscutting relationships described above, probably reflects regional cooling

$\mathrm{kh} \quad H u n t i n g t o n$ Formation (Upper and Middle Triassic) - Greenstone volcaniclastic, volcanic, and minor intrusive rocks (southwestern and west-central pl. 1; Mann, 1991). Volcanic sandstone and conglomerate and minor limestone and chert are prevalent in Cuddy Mountain area. Volcanic rocks are tuffs, tuff breccias, and flows whose compositions are andesite, dacite porphyry, spilite, and keratophyre. To the southeast, volcaniclastic and volcanic rocks of the Huntington Formation are intruded by granodiorite, quartz diorite, and gabbro plutons ( $\mathrm{kgd}$, kqd, kgb, respectively). Rocks of the Huntington Formation are the southeasternmost of the oceanic terranes exposed in western Idaho. At least 2,600 $\mathrm{m}$ exposed in Cuddy Mountain area (Mann, 1991) 
km Martin Bridge Formation (Upper Triassic) - Recrystallized limestone and calcareous shale in Snake River Canyon (northwestern edge pl. 1); increases in metamorphic grade northeastward across thrust faults to (1) marble and calcareous phyllite and (2) coarsegrained marble to calcareous schist in area of Pollock Mountain (north-central pl. 1). Calcareous phyllite and schist contain calcite, plagioclase, biotite or phlogopite, muscovite, chlorite, rounded fine-grained quartz, epidote, siderite, and graphite. Limestone and marble are medium- to light-gray calcite; minor phlogopite and graphite at highest grades. In Snake River Canyon, limestone unconformably overlies Doyle Creek Formation (Ksd; Vallier, 1977). However, along trend to the northeast, Martin Bridge Formation gradationally overlies volcaniclastic sediments of Doyle Creek Formation (Ksd; McCollough, 1984; Lund and others, 1993). As much as $580 \mathrm{~m}$ thick (Vallier, 1977).

Herein, the name "Martin Bridge Formation" is used in preference to "Martin Bridge Limestone" (Hamilton, 1963) because, both in its type locality in Oregon (Ross, 1938; Follo, 1986, 1994) and in central Idaho (Lund and others, 1993), the unit is an interlayered succession of limestone and calcareous shale. In some studies, the interfingered limestone and shale (or their metamorphic equivalents) have been given separate names (Hamilton, 1963; Aliberti, 1988), which has complicated the understanding of the stratigraphy and structure. Additionally in areas where structure is complex, lenses of limestone in the upper Seven Devils Group have been mistakenly called Martin Bridge Limestone (Hamilton, 1963; Aliberti, 1988). Usage in this report is that Martin Bridge Formation refers to the interbedded limestone and calcareous shale above the volcanic and volcaniclastic rocks of the Seven Devils Group; however, because of the stratigraphic and structural complexity, it may include some strata from the overlying Lucile Formation (exposed north of map area) and underlying Doyle Creek Formation (Ksd)

\section{Seven Devils Group}

Upper part of Seven Devils Group, undivided (Triassic) — Volcanic and volcaniclastic rocks of Seven Devils Group not subdivided in areas of difficult access between Snake and Rapid Rivers in Seven Devils Mountains (northwestern pl. 1)

Ksd Doyle Creek Formation (Upper Triassic) — Red and lesser green greenschist facies volcaniclastic strata derived from underlying volcanic units and lesser basalt flows. Volcaniclastic rocks include sandstone, siltstone, conglomerate, and volcanic breccia. Beds vary greatly in thickness and in composition along trend. Amount of clastic material increases upward in section (Vallier, 1977) and thin limestone lenses are common (Lund and others, 1993). Named and described by Vallier (1977) for exposures in northwestern part of plate 1. More than $300 \mathrm{~m}$ thick at top of Seven Devils Group

Ksw Wild Sheep Creek Formation (Upper and Middle Triassic) - Greenschist facies basalt, basaltic andesite, andesite, lesser volcaniclastic rocks, and minor limestone. Volcanic flow rocks are now mostly altered to spilite and keratophyre. Volcaniclastic rocks include volcanic breccia, sandstone, and siltstone in layers 5-50 m thick. A limestone layer as much as $50 \mathrm{~m}$ thick is in upper one-third of formation. Base is predominantly keratophyric andesite, middle part is mainly spilitic basalt, and upper part is mainly volcaniclastic and limestone beds. Unit is primarily green in contrast to the mostly red, gradationally overlying Doyle Creek Formation. Named and described by Vallier (1977) for exposures in northwestern part of plate 1. Faunal dates indicate latest Middle Triassic to early Late Triassic age. About 2,500 m thick (Vallier, 1977)

Psh Hunsaker Creek Formation (Lower Permian) - Pyroclastic rocks, water-laid tuffs, and volcaniclastic rocks predominate; minor keratophyre and spilite flow units. Graded bedding in tuffs is characteristic. Volcaniclastic rocks are conglomerate, breccia, sandstone, and siltstone. Clasts commonly contain some plutonic rocks indicating deeply eroded source terrain. Upper contact unconformable. Faunal dates are Early Permian. Named and described by Vallier (1977) for exposures in northwestern part of plate 1. Thickness more than 2,500 $\mathrm{m}$ (Vallier, 1977) 
Psw Windy Ridge Formation (Lower Permian) - Greenschist facies quartz keratophyre tuff, tuff breccia, and flows. Grayish green; little evidence of bedding. Distinguished from overlying units by lack of clastic rocks. Base not exposed, top may be unconformable, and unit may be a local deposit rather than regionally continuous. Not well dated but probably Early Permian. Named and described by Vallier (1977) for exposures in northwestern part of plate 1. Thickness estimated at $250 \mathrm{~m}$ (Vallier, 1977)

Pqd Metamorphosed quartz diorite (Late Permian?) —-Syndeformational quartz diorite plutons intruded into northern extension of Oxbow-Cuprum shear zone (Cook, 1954; Cannon and others, in Hamilton, 1963; White, 1968; Gualtieri and Simmons, 1978). Intruded mafic plutons $(\mathrm{Pd})$ and mylonitic gneisses that may be early volcanic rocks of Seven Devils Group or possibly basement to Wallowa terrane (ks). Less deformed and metamorphosed than mafic plutons (Pd; White, 1968)

$\mathrm{Pd}$

Metamorphosed mafic plutons (Late Permian)-Strongly deformed gabbro and diorite plutons intruded into basement of Wallowa terrane (MzPzn). Late Permian U-Pb date of $249 \mathrm{Ma}$ on zircon (Walker, 1982, 1986) from plutonic rock south of The Oxbow on Snake River (west-central edge pl. 1) indicates that these plutons were emplaced between early (Lower Permian) and late (Upper and Middle Triassic) stages of arc volcanism. These plutons are related to formation of early part of Seven Devils Group (Vallier, 1995).

Gabbro and diorite plutons in southern Seven Devils Mountains have not been dated but were mapped as part of an older group of pre-deformational plutons (Cook, 1954; Cannon and others, in Hamilton, 1963; White, 1968; Gualtieri and Simmons, 1978). These intruded and were sheared together with greenschist metamorphic rocks of the Seven Devils Group and possible basement gneisses (Psw and MzPzgn; northwestern pl. 1). They are on trend with dated Late Permian plutonic rocks at The Oxbow (west-central edge pl. 1) and probably belong to the same plutonic episode (Vallier, 1995)

MzPzgn Mafic gneiss (Mesozoic and Paleozoic) - Amphibolite, hornblende schist, metabasalt, and metagabbro. Forms a mylonitized and sheared mafic gneiss complex that is basement to greenstone volcanic rocks of Wallowa terrane. Exposed at The Oxbow on Snake River (west-central edge pl. 1) and possibly in southern Seven Devils Mountains (White, 1968) as part of Oxbow-Cuprum shear zone (Vallier, 1967, 1977). Minimum age of $249 \mathrm{Ma}$ on quartz diorite (Pqd) that intruded the complex (U-Pb zircon methods, Walker, 1986). Deformation indicates left-lateral shearing (Ave Lallemant and others, 1985), which is dated by ${ }^{40} \mathrm{Ar} /{ }^{39} \mathrm{Ar}$ of metamorphic hornblende and biotite between 217 and $224 \mathrm{Ma}$ (Ave Lallemant and others, 1980)

\section{Baker terrane}

MzPzb Phyllite and chert of Baker terrane, undivided (Mesozoic and Paleozoic) — Baker terrane characterized by massive and ribbon cherts, cherty phyllite, cherty argillite, cherty limestone, phyllitic argillite, limestone, and all gradations among these lithologies. Cherts, argillites, and phyllites are well bedded but limestones are lensoid. Rocks are conspicuously folded, mostly into isoclinal folds, but beds can be traced along strike. Some strongly deformed metagabbro included as part of unit (Mann, 1991). Metamorphic grade is lower greenschist facies. Faulted over Izee terrane along Cuddy Mountain fault (west-central pl. 1)

High-grade metamorphic and plutonic rocks, terrane unknown

KJtf Metamorphosed quartz diorite, tonalite, and granodiorite (Cretaceous and Jurassic)Larger bodies of strongly deformed quartz diorite, tonalite, and granodiorite locally mapped within metamorphosed volcanic/plutonic complex (east side pl. 1). Plutons in North Fork of the Weiser River and Hazard Creek drainages dated by U-Pb zircon at $158 \pm 2 \mathrm{Ma}$ and about 160 Ma (D.M. Unruh, J.N. Aleinikoff, and K. Lund, unpub. data, 2002). Mapped areas include minor deformed plutons and dikes dated at about $110 \mathrm{Ma}$ (K. Lund and D.M. Unruh, unpub. data, 2002) and at 118 $\pm 5 \mathrm{Ma}$ (Manduca, 1988); probably related to Salmon River suture complex (Kgn and Kpgdm). Included as part of Hazard Creek Complex of Manduca and others (1993) and gneissic quartz diorite unit of Hamilton (1969) 
KJPvp Metamorphosed volcanic/plutonic complex (Cretaceous and Jurassic to Permian)Heterogeneous mixture of Jurassic to Permian island-arc volcanic, volcanogenic, and plutonic rocks; underwent Jurassic and Cretaceous metamorphism and deformation. Considerable variation exists among different rock types; protoliths not identifiable for much of complex (fig. B6); complexity of intrusion and deformation too great to be shown at this scale (for detail, see Hamilton, 1969; Manduca, 1988). Includes amphibolitic and biotitic paragneisses formed from volcanogenic sedimentary, volcanic, and plutonic protoliths, probably all Jurassic to Permian rocks of the Blue Mountains island arc. Possible earlier events recorded as vestiges of Jurassic (pre-144 Ma) metamorphism in garnets (Selverstone and others, 1992; Getty and others, 1993) and perhaps related to intrusions of unit KJtf. Also includes tonalitic, trondhjemitic, and granodioritic orthogneisses, some of which formed from Cretaceous intrusions into the Jurassic to Permian protolith and others of which may have originated as Jurassic to Permian island-arc plutons. Complexity in outcrop is similar to zone of infiltration in the Permian Canyon Mountain Complex, Oregon, of the Baker terrane (Bishop, 1995; Walker, 1995), as well as to gneisses in the basement of the Wallowa terrane (Vallier, 1967, 1995; White, 1968; Ave Lallement and others, 1980, 1985; Balcer, 1980; Walker, 1986). Oldest dated deformed plutons (KJtf, where mapped separately) are about $158 \pm 2 \mathrm{Ma}$ (K. Lund, D.M. Unruh, and J.N. Aleinikoff, unpub. data, 2002). Includes minor deformed plutons and dikes dated at about $110 \mathrm{Ma}$ (K. Lund and D.M. Unruh, unpub. data, 2002) and at $118 \pm 5$ Ma (Manduca, 1988), probably related to Salmon River suture complex (Kgn and Kpgdm). In northwestern exposures, metavolcanic parts of unit are gradational with undifferentiated metamorphosed rocks of Blue Mountains island arc (JPmv, JPam) and Riggins Group (JPrs, JPrl, JPrf). Orthogneisses and predominantly plutonic parts of unit are equivalent to Hazard Creek Complex of Manduca and others (1993) and gneissic quartz diorite unit of Hamilton (1969); entire complex is equivalent to gneiss of Council Mountain of Schmidt $(1957,1964)$

JPmv Metamorphosed rocks of Blue Mountains island arc, undifferentiated (Jurassic to Permian) - Calcareous schist, chlorite-biotite schist, and amphibolite gneiss along west side of Salmon River suture (central fig. A3; eastern pl. 1) where lithologies not mapped separately. Metamorphic grade ranges from greenschist to middle amphibolite facies. Premetamorphic protoliths were volcanic and volcanogenic sedimentary rocks of an allochthonous island-arc terrane. These may be (1) equivalent to part of Riggins Group (Hamilton, 1963; Onasch, 1977, 1987; Lund, 1984; Lund and others, 1993, 1997), (2) metamorphic equivalents of one of the terranes of Blue Mountains island arc, or (3) remnant of an unknown oceanic terrane. Gradational with metamorphosed volcanic components of metamorphosed volcanic/plutonic complex (KJPvp)

JPam Amphibolite gneiss (Jurassic to Permian) - Strongly deformed amphibolite and garnet amphibolite gneiss (fig. B7A). Originated primarily as volcanic rock, now metamorphosed to amphibolite facies. Retains some evidence of original volcanic textures such as possible layering and volcanic conglomerate (fig. B7B). May be equivalent in part with the Lightning Creek Schist of the Riggins Group (JPrl) (Hamilton, 1963; Onasch, 1977, 1987; Lund, 1984; Lund and others, 1993, 1997). Between the Rapid and Little Salmon Rivers (northeastern pl. 1), these rocks were thrust over muscovite-chlorite schist of the Lightning Creek Schist (JPrl), graphitic calcareous biotite schist of the Squaw Creek Schist (JPrs), and upper greenschist facies rocks of Wallowa terrane ( $\mathrm{ks}$ and $\mathrm{ksd}$ ). Amphibolite gneiss forms upper plate of Pollock Mountain thrust fault (Aliberti, 1988). Gradational with metamorphosed volcanic components of metamorphosed volcanic/plutonic complex (KJPvp)

\section{Riggins Group (Jurassic to Permian)}

JPrs Squaw Creek Schist - Graphitic biotite calc-silicate schist, biotite gneiss, and minor marble (Hamilton, 1963; Onasch, 1977, 1987; Lund, 1984; Lund and others, 1993, 1997); age and terrane of origin unkown. Compositionally, these may be a higher metamorphic grade equivalent of the Triassic to Jurassic sedimentary rocks of Wallowa terrane (Lund, 1984; Lund and others, 1993) or the Huntington Formation of Olds Ferry terrane (Brooks and Vallier, 1978; Vallier, 1995) 
JPrl Lightning Creek Schist - Garnet-amphibolite and biotite or chlorite schist (Hamilton, 1963; Onasch, 1977, 1987; Lund, 1984; Lund and others, 1993, 1997); age and terrane of origin unkown. Originated as volcanic and volcanogenic sedimentary rocks metamorphosed to amphibolite facies. Thrust westward over lower grade island-arc rocks (northeastern pl. 1)

JPrf

Fiddle Creek Schist - Silvery-green muscovite-chlorite schist named for exposures along strike to the north-northeast (Hamilton, 1963; Onasch, 1977, 1987; Lund, 1984; Lund and others, 1993, 1997); age and terrane of origin unknown. Forms a structural plate along east side of upper Rapid River (northeastern pl. 1). Unit originated as volcanic and volcanogenic sedimentary rocks metamorphosed to upper greenschist and amphibolite facies. Plate is sandwiched between underlying low-grade rocks of Wallowa terrane and overlying high-grade island-arc rocks (JPam and JPmv). Compositionally, these may be a higher metamorphic grade equivalent of the Seven Devils Group of Wallowa terrane (Lund, 1984; Lund and others, 1993) or the Huntington Formation of Olds Ferry terrane (Vallier and Brooks, 1978)

\section{LAURENTIAN CONTINENTAL ROCKS}

Meta-intrusive rocks

OEsd

Zsd

ZYam

Syenite and diorite (Ordovician to Cambrian) - Light- to medium-colored syenite to quartz syenite and dark-colored syenodiorite to amphibolite; minor pyroxenite and gabbro. Syenite and syenodiorite have mutual crosscutting relationships and complicated segregations of light and dark varieties indicating mixing of two chemically different magmas. Named Yellowjacket pluton; exposed near Middle Fork Peak (southeast edge pl. 2) and town of Yellowjacket, Idaho (east of pl. 2). Intruded the Yellowjacket Formation (Yy) and Hoodoo Quartzite (Yh). Chemistry similar to that of Neoproterozoic syenitediorite suites (Zsd), along same trend. U-Pb SHRIMP dating on zircons indicates date of $491 \pm 4$ Ma (J.N. Aleinikoff, K.V. Evans, and K. Lund, USGS, unpub. data, 2003)

Syenite-diorite suite (Neoproterozoic) - Light- to medium-colored syenite to quartz syenite and dark-colored syenodiorite to amphibolite; minor pyroxenite and gabbro. Forms three bimodal intrusive bodies that crop out in a west-northwest line along Big Creek (Cater and others, 1973), named Ramey Ridge (Leonard, 1963), Acorn Butte, and Rush Creek Point suites from northwest to southeast (Cater and others, 1973). Light-colored syenites are mainly composed of intergrown potassium feldspar and albite, lesser hornblende and biotite, and minor quartz and magnetite. Dark-colored syenodiorite and amphibolite are nearly equal mixtures of albite and mafic minerals (biotite and hornblende). Syenite and syenodiorite have mutual crosscutting relationships and complicated segregations of light and dark varieties, indicating mixing of two chemically different magmas. Dark compositional variation first identified as metavolcanic xenoliths in Ramey Ridge Suite (Ramey Ridge Complex of Leonard, 1963). Thin-section observation shows that these rocks have undergone greenschist facies metamorphism and deformation but this is not readily apparent in hand specimen. U-Pb SHRIMP dating on zircons indicates dates of $651 \pm 5 \mathrm{Ma}$ for Ramey Ridge suite, $661 \pm 7 \mathrm{Ma}$ for Acorn Butte suite, and $651 \pm 5 \mathrm{Ma}$ for Rush Creek Point suite (J.N. Aleinikoff, K.V. Evans, and K. Lund, USGS, unpub. data, 2003). The similar looking Yellowjacket pluton (O€sd; east edge pl. 2) is of the same composition but much younger

Amphibolite gneiss and amphibolite dikes (Neoproterozoic? and Mesoproterozoic?)Amphibolite gneiss consists mostly of hornblende and biotite and lesser plagioclase. Large bodies mapped near Buckhorn Lake (west side pl. 2) and Snowbank Mountain (southeast corner pl. 1), dikes mapped in Neoproterozoic and Mesoproterozoic strata near Big Creek (central pl. 2); also a major component of gneiss units (ZYs and Ygn). May be equivalent to the Mesoproterozoic amphibolites that are closely related to augen gneiss (Yagn; Evans and Zartman, 1990; Doughty and Chamberlain, 1996). Alternatively, some may be higher grade equivalents to the Neoproterozoic mafic metavolcanic rocks (Ze) or syenodiorite (Zsd) or may be dikes related to these Neoproterozoic igneous rocks 
Yagn Granitic augen gneiss (Mesoproterozoic) - Foliated porphyritic biotite granite and granitic augen gneiss. Potassium feldspar phenocrysts commonly 1-3 cm long. Exposed in far eastern part of forest along Middle Fork Salmon River both as discrete plutons (fig. B8) and as migmatitic stringers and veins (figs. B9 $A, B$ ) in metasedimentary biotite gneiss (Ygn; extreme northeast corner pl. 2). Equivalent to the Mesoproterozoic granitic augen gneiss and porphyritic granite near Shoup, $20 \mathrm{~km}$ to the east, and Elk City, $30 \mathrm{~km}$ to the northwest (Evans and Fischer, 1986; Evans and Zartman, 1990)

Metamorphosed strata

€Zgm Gray marble (Cambrian or Neoproterozoic) —Medium- to dark-gray marble. Fine- to medium-grained calcite; minor actinolite-tremolite needles as long as $2 \mathrm{~cm}$. Centimeterscale layers (fig. B10A), some that are tan silty carbonate, may represent bedding. Mottled bedding surfaces suggest bioturbation or mud cracks (fig. B10B). Calc-silicate minerals are more abundant at base and top of unit, and growth of these minerals has obscured primary features. Calcareous layers are gradational and interlayered with quartzite layers near top and base of unit at Cinnabar Peak (central pl. 2). Preserved in Gospel Peaks and Stibnite roof pendants (fig. A3; northwestern and south-central pl. 2, respectively). Maximum thickness about $250 \mathrm{~m}$, estimated from mapped exposures, at Cinnabar Peak (south-central pl. 2)

\section{Windermere Supergroup}

\section{Gospel Peaks succession D}

€Zub Umbrella Butte Formation (Cambrian? and Neoproterozoic) — Quartzite, quartzitepebble conglomerate, and minor sillimanite-biotite-quartz schist and marble. Quartzite predominates in upper part of unit. Planar crossbeds with slightly concave laminae are prevalent in quartzite at Sugar Mountain (fig. B11A, south-central pl. 2) and in overturned exposures at Cinnabar Peak in Stibnite roof pendant (fig. A6, south-central pl. 2). Marble, calc-silicate metasandstone, and schist in 5- to 10-m-thick layers are traced at wide intervals in upper quartzite-dominant parts of formation. Pebble conglomerate near base of formation and possibly in lenses higher in unit; conglomerate layers are about $10 \mathrm{~m}$ thick and contain well-rounded pebbles as much as $3 \mathrm{~cm}$ long and $1 \mathrm{~cm}$ wide (fig. B11B). Sillimanite-biotite-quartz schist layers are common at or near base of unit (fig. B11C) below conglomerate lenses. Part of the Umbrella Butte Formation is multiply repeated in Stibnite roof pendant probably due to unmapped thrust faults or tight folds. Exposures in forest are only about $150 \mathrm{~m}$ thick because of fault truncation or possibly because of limited deposition; estimated thickness about 1,500 $\mathrm{m}$ in Gospel Peaks roof pendant (northwest margin pl. 2; Lund, 1984)

Missouri Ridge Formation (Neoproterozoic) - Carbonaceous metasiltite and thinly layered calc-silicate-bearing marble in 5- to 15-m-thick compositional zones. Unique ribbon-laminated exposures (fig. B12A) of alternating fine-grained quartzo-feldspathic layers intercalated with thin marble and calc-silicate-bearing layers (fig. B12B). Individual beds generally $0.5-2 \mathrm{~cm}$ thick. Lower contact is a narrow gradational zone of calc-silicatedominant metasiltites. Upper contact may be an unconformity but is poorly preserved. The Missouri Ridge Formation overlies the Moores Lake Formation ( $\mathrm{Zml})$ in Big Creek and Stibnite roof pendants. Estimated to be about $450 \mathrm{~m}$ thick but exposures are complicated by deformation and intrusion

Zml Moores Lake Formation (Neoproterozoic) - Primarily quartzite and lenses of quartzitecobble conglomerate. Quartzite composed of recrystallized and intergrown quartz grains. Upper parts of unit are more than 95 percent quartz; minor feldspar and mica make up rest of rock. Upper part of unit is massive and bedding is difficult to identify but, in middle and lower parts of unit, faint uncommon layering is defined by muscovite- and biotite-rich laminae. Minor crossbedding is the only primary feature and is important for indicating stratigraphic younging directions for much of section. Base of unit in Gospel Peaks roof pendant contains lenses of quartzite-cobble conglomerate (fig. B13). Cobbles as much as 
$15 \mathrm{~cm}$ across are in micaceous feldspathic quartz-rich matrix. Where this part of section is well exposed in Gospel Peaks roof pendant, the presence of conglomerate lenses and the absence of the Goldman Cut Formation suggest that base of formation is an unconformity. Thickness of incomplete unit exceeds $500 \mathrm{~m}$

\section{Gospel Peaks succession B}

Goldman Cut Formation (Neoproterozoic) - Silvery-gray, rusty-brown-weathering, fine-grained andalusite-mica schist; preserved only in Big Creek and Stibnite roof pendants. Foliation and layering cause flaggy partings. Layering defined by micas and andalusite. Andalusite needles are aligned with foliation but not lineated. Primary features or compositional layering are not well preserved but original sedimentary layering with possible graded bedding (fig. B14) was found in Big Creek roof pendant (fig. A3; central pl. 2). About $250 \mathrm{~m}$ of unit is at intruded base of Big Creek roof pendant where base is gradational with the Moores Station Formation. A thinner interval, about $50 \mathrm{~m}$ thick, is traced in a thrust sheet across southeastern part of Stibnite roof pendant (fig. A3; central pl. 2)

Moores Station Formation (Neoproterozoic) - Composite unit of interbedded gray marble; fine-grained, black, rusty-weathering quartzite; rusty-weathering muscovite schist; and calc-silicate gneiss. Marble layers about $2-15 \mathrm{~m}$ thick; interbedded with layers of apatite- and pyrite-rich, fine-grained, black, red- to gray-weathering quartzite about 15-25 m thick (fig. B15). Orange-stained quartzite intervals, only about $10 \mathrm{~m}$ thick, are locally exposed. Muscovite schist commonly contains some garnet, biotite, staurolite, calcic amphibole, and (or) epidote. No primary features were found but the distinct compositional layers in this unit suggest original bedding. Probably formed as alternating black shale and limestone with compositional gradations; apatite-pyrite black quartztite and possibly staurolite-garnet-muscovite schist are silicate facies iron-formation layers. Very important and distinct regional marker unit; best exposed in Gospel Peaks and Marshall Mountain roof pendants. Structural complication makes thickness estimates difficult but, based on map exposure width in Gospel Peaks roof pendant, probably as much as $300 \mathrm{~m}$ thick

Edwardsburg Formation (Neoproterozoic) - Compound metamorphosed bimodal volcanic succession and associated glaciogenic conglomerate. Described section exposed west of settlement of Big Creek (center pl. 2); incomplete sections in other roof pendants. Most widely recognized members of the formation are layered amphibolite (Golden Cup Member) and associated mafic graywacke conglomerate containing quartzite and metacarbonate clasts (Wind River Meadows Member). Described in descending order:

Hogback Rhyolite Member-Metamorphosed porphyritic rhyolite tuff; relict potassium feldspar, plagioclase, and bipyramidal quartz phenocrysts (fig. B16A). Groundmass biotite and muscovite form a faint metamorphic foliation. Eutaxitic and fiamme structures as well as flow breccia are preserved, indicating that the Hogback Rhyolite Member is a rhyolite flow (rather than an intrusion); only preserved near settlement of Big Creek. Dated at $684 \pm 5 \mathrm{Ma}$ by U-Pb zircon methods (Lund and others, 2003). About $40 \mathrm{~m}$ thick.

Placer Creek Member-More regionally widespread than, and probably laterally interfingering with, the Hogback Rhyolite Member. Made up of volcanogenic matrix conglomerates. Upper conglomerate contains heterogeneous mixture of volcanic, quartzite, and calc-silicate gneiss pebbles (fig. B16B). Pebbles in upper conglomerate are stretched and as much as $4 \mathrm{~cm}$ wide by $10 \mathrm{~cm}$ long. Lower volcanic conglomerate contains volcanic clasts of diverse compositions (fig. B16C). Pebbles in lower conglomerate appear to be stretched and are mostly about $1 \mathrm{~cm}$ wide by $2 \mathrm{~cm}$ long.

Golden Cup Member-Metamorphosed mafic volcanic rocks of medium- to coarse-grained amphibolite containing relict pyroxene (now plagioclase and chlorite) and plagioclase phenocrysts (Leonard, 1962) and fine-grained indistinctly layered amphibolite containing hornblende, biotite, plagioclase, and quartz. In coarser grained porphyritic amphibolites, stretched calcite-filled cavities suggest amygdaloidal texture (fig. B16D). Possible fragmental and pillow textures are also found. These porphyritic amphibolites were volcanic flows and are mostly in middle of member. Fine-grained, indistinctly layered amphibolite may have originated as mafic volcaniclastic rocks. Approximately $400 \mathrm{~m}$ thick at Big Creek. 
Wind River Meadows Member-Interfingered rhyodacite tuffs and conglomerates. Regionally widespread, massive, matrix-supported, 2- to 15-m-thick graywacke conglomerate; quartzite and calc-silicate gneiss cobbles and pebbles (fig. B16E). Clasts are as long as $20 \mathrm{~cm}$ but mostly less than $4 \mathrm{~cm}$; rounded and structurally stretched. Matrixsupported conglomerate is as thick as $200 \mathrm{~m}$. Rhyodacite flow breccia, tuff, and waterworked tuff locally found low in unit. Rhyodacite has relict plagioclase and potassium feldspar phenocrysts. Volcanic breccia fragments of similar lithology are common (fig. $\mathrm{B} 16 F$ ). Primary sedimentary structures, including flow-breccia tuff and water-laid tuff with graded bedding, are locally preserved. Rhyodacite dated at $685 \pm 7 \mathrm{Ma}$ (Lund and others, 2003). About $20 \mathrm{~m}$ thick west of Big Creek (central pl. 2). Thin unit of mafic volcanic rocks, about $5 \mathrm{~m}$ thick, found on ridge about $6 \mathrm{~km}$ west of Big Creek. Fine-grained quartzite, 2-3 m thick, found at base in several localities.

Thickness of the Edwardsburg Formation, estimated from map width of exposures, is $700 \mathrm{~m}$. Graded bedding in volcaniclastic sedimentary part of rhyodacite in the Wind River Meadows Member west of Big Creek shows that section there is overturned. Where preserved, contacts at top and base are gradational

Anchor Meadow Formation (Neoproterozoic?) —-Marble and calc-silicate metasiltite underlying diamictite and volcanogenic rocks of Gospel Peaks succession B. Coarsegrained, light-grayish-green tremolite marble predominates at top of unit; medium-grained, dark-green and purple, layered calc-silicate metasiltite rock predominates at bottom. Contact of tremolite marble with Edwardsburg Formation (Ze) may be gradational in overturned exposures on ridge west of Big Creek (center pl. 2) but may be unconformable in other locations because pebbles of this unit are incorporated into diamictites of the Edwardsburg Formation. Basal contact is gradational. About $100 \mathrm{~m}$ thick

Zsm Square Mountain Formation (Neoproterozoic?) - Fine-grained, white to light-buff quartzite; subrounded bimodal quartz grains, minor mica, feldspar, and oxide grains. A few lenses contain remnant subrounded quartz granules and pebbles and subrounded ironoxide granules and reddish chert (fig. B17A). Granule beds with small quartzite pebbles, only as large as $1 \mathrm{~cm}$ across, noted on ridge south of Smith Creek and at Snowslide Peak (central pl. 2). Ripple crossbedding and ripple-marked surfaces present (fig. B17B). Compositionally, this quartzite is less rich in feldspar and mica than Mesoproterozoic biotite-feldspar-quartz metasandstone that is correlated with the Gunsight Formation (Ylg). Unit Zsm structurally overlies both Neoproterozoic and Mesoproterozoic strata on ridge northwest of Big Creek (center pl. 2). At this same location, amphibolite sills (ZYam) cut quartzite of unit Zsm but not the dated Neoproterozoic (and possible Cambrian) units that are structurally below but younger. Actual thickness not known because of structural disruption but probably greater than $500 \mathrm{~m}$

Zpp Plummer Point Formation (Neoproterozoic?) - Reddish-gray-weathering, mediumgrained muscovite-biotite schist and amphibolite; locally contains garnet-, sillimanite-, or quartz-rich layers. Top gradational with the overlying Square Mountain Formation in Gospel Peaks roof pendant. No primary sedimentary features found. Unit Zpp consistently found above Mesoproterozoic rocks and below dated Neoproterozoic rocks. Metamorphic grade, structural features, and bedding orientation typically differ below this unit, suggesting that base is an unconformity in places and structural elsewhere. About $200 \mathrm{~m}$ thick

Ys Swauger Formation (Mesoproterozoic) — Dark-gray and white, massive, quartz-rich metasandstone. Rock contains 5-15 percent feldspar; muscovite and biotite amount to as much as 5 percent of rock. Quartz grains are rounded to subrounded and medium grained. Massive to medium bedded; beds $0.1-0.5 \mathrm{~m}$ thick. Gradationally overlies the Gunsight Formation (Ylg); unit Ys strata may be mapped with the Gunsight Formation, particularly in Profile Creek and upper middle part of Big Creek. Unconformably overlain by Neoproterozoic units 


\section{Lemhi Group}

Ylg Gunsight Formation, upper part (Mesoproterozoic) - Prominent, tan to gray, fine- to medium-grained, $10 \mathrm{~cm}$ - to $0.5 \mathrm{~m}$-thick metasandstone layers alternating with rustyweathering, millimeter- to centimeter-thick biotite phyllite layers (fig. B18A) and massive feldspathic metasandstone. Lower to middle greenschist facies metamorphism. Formation becomes more quartz rich upward in section and grades into the Swauger Formation. Crossbedding, soft-sediment deformation (fig. B18B), and straight-crested ripple marks (fig. B18C) locally preserved in rocks from the Gunsight-Swauger transition. Base of unit exposed near Center Mountain (central pl. 2), where unit gradationally overlies biotite phyllite of the probable upper part of the Apple Creek Formation (Ylau). Not possible to determine accurate thickness but estimated to be about $1,000 \mathrm{~m}$. Unit is similar to and correlated with rocks near the Blackbird mine area (about $30 \mathrm{~km}$ east of pl. 2; Connor and Evans, 1986; Nash and Hahn, 1989; Connor, 1990, 1991) that are now mapped as Mesoproterozoic Gunsight Formation (Tysdal, 2000a).

Higher grade exposures in Profile Creek (center pl. 2) are interpreted as primarily upper part of the Gunsight Formation and probably include undifferentiated rocks of the Swauger Formation. Exposures in Profile Creek were previously called "older quartzite" by White (1941) to distinguish these from other quartzites that White mapped nearby as younger rocks but that are herein mapped as part of the Neoproterozoic Windermere Supergroup and related strata. Biotite-feldspar quartzite gneiss (fig. B18D; Ybfq) in Marshall Mountain roof pendant (fig. A3) may be metamorphic equivalent

Ylau Apple Creek Formation, upper part (Mesoproterozoic) — Laminated, gray and green chlorite-biotite phyllite and gray quartzose phyllite. Where cleavage is weak or parallel to layering, rock has (1) prominent, fine, light-and-dark laminations on millimeter to centimeter scale, (2) graded bedding, and (3) sedimentary water-escape structures of lightcolored, more quartzose material from some layers that appear to cut up into intervening dark micaceous layers (fig. B19A, B). Metamorphic grade is lower to middle greenschist facies. Crops out along Big Creek (east-central pl. 2). Upper contact with biotite metasandstone-phyllite of the probable Gunsight Formation (Ylau) is gradational near Center Mountain (central pl. 2) but elsewhere upper contact is faulted. Lower contact not exposed. Estimated thickness more than 1,000 m.

Previously correlated with the Mesoproterozoic Yellowjacket Formation (Cater and others, 1973) because composition is similar to that of strata mapped as Yellowjacket Formation to the east (for example, Connor and Evans, 1986). Based on revision of Mesoproterozoic stratigraphy near Blackbird, Idaho (Tysdal, 2000a, b; Tysdal and others, 2000), and on sedimentary structures and stratigraphic succession, unit is herein mapped as banded siltite unit of the Apple Creek Formation

Yaq Argillaceous quartzite (Mesoproterozoic) - Biotite phyllite and quartzite interlayered in centimeter-scale layers that are a preserved sedimentary lamination. Metamorphosed to middle and upper greenschist facies. Informally named unit (Ross, 1934) stratigraphically overlies the Hoodoo Quartzite in lower Big Creek drainage (R.S. Lewis, Idaho Geological Survey, written commun., 1996; east-central pl. 2). Top of unit not exposed. Thickness in study area unknown

Yh Hoodoo Quartzite (Mesoproterozoic) — Light-gray and tan biotite-feldspar metasandstone and feldspathic quartzite. Some preserved crossbedding, lenticular bedding (fig. B20A), and ripple marks (fig. B20B). Metamorphosed to middle and upper greenschist facies. Traced from the reference section (east-central edge pl. 2; Ross, 1934; Ekren, 1988; Tysdal, 2000b; Tysdal and others, 2000) across Middle Fork Salmon River to lower Big Creek (this study), where unit Yh stratigraphically overlies phyllites (R.S. Lewis, Idaho Geological Survey, written commun., 1996) herein correlated with the Yellowjacket Formation (Yy). Thickness in study area unknown 
Yy Yellowjacket Formation (Mesoproterozoic) — Gray, finely layered, biotite-feldspar metasiltite and phyllite. Compositional layering is, in part, preserved sedimentary fine lamination, at millimeter and centimeter scale (fig. B21A). Centimeter-thick layers with preserved ripplecross lamination (fig. B21B) found in Middle Fork Salmon River drainage. Metamorphosed to middle and upper greenschist facies. Traced from reference section (east-central edge pl. 2; Ross, 1934; Ekren, 1988; Tysdal, 2000b; Tysdal and others, 2000) across Middle Fork Salmon River to lower Big Creek where it underlies quartzite (R.S. Lewis, Idaho Geological Survey, written commun., 1996) of the Hoodoo Quartzite. Thickness in study area unknown

\section{High-grade metamorphic units}

Ybfq Biotite-feldspar quartzite (Mesoproterozoic) - Primarily mapped in Marshall Mountain and Stibnite roof pendants and around Yellow Pine and in scattered outcrops elsewhere in eastern part of forest. Lit-par-lit injection and possible partial melting commonly destroyed primary features (fig. B18D). Metamorphosed to upper amphibolite facies. Thickness unknown. Probably equivalent to biotite arkosic metasandstone of the Swauger and Gunsight Formations (Ys and Ylg)

Ygn Biotite phyllite, gneiss, and migmatite (Mesoproterozoic) —Biotite-quartz-feldspar phyllite and migmatite gneiss; includes some augen gneiss probably equivalent to unit Yagn, and some amphibolite probably equivalent to unit ZYam (figs. B8 and B9), where not mapped separately due to difficult access. In eastern exposures of upper greenschist facies metamorphism, some gross bedding preserved (but not fine details) despite strong ductile deformation. In western exposures of amphibolite facies metamorphism, sedimentary structures mostly not preserved in biotite gneiss and migmatite. Thickness unknown. Compositions and location suggest that much of unit, especially where exposed near mouth of Middle Fork Salmon River (northeastern pl. 2), may be metamorphosed Mesoproterozoic Apple Creek Formation (Ylau)

Yq Quartzite and layered quartz-rich metasandstone (Mesoproterozoic) - Quartz-rich metasandstone interlayered with centimeter-scale calc-silicate and phyllite layers in upper part and quartzite and feldspathic quartzite in lower part. Quartzite contains less than 10 percent biotite and muscovite; ripple cross-lamination and small-scale interference ripple patterns present on bedding surfaces (Lund, 1984). Base is structurally detached from underlying biotite phyllite and calc-silicate gneiss (Ybc); top eroded. Crops out in Nez Perce National Forest (northern pl. 2). Thickness about 3,200 m (Lund, 1984). May be equivalent to the Hoodoo Quartzite and argillaceous quartzite units (Yh and Yaq, respectively)

Ybc Calc-silicate and biotite gneiss (Mesoproterozoic) - Dark-green, medium-grained calc-silicate and biotite gneiss and tan calc-silicate gneiss. Calc-silicate gneiss layers composed of epidote, tremolite-actinolite, quartz, biotite, and feldspars. Interlayered with biotite-quartzfeldspar gneiss and well-layered phyllite to schist. Primary sedimentary features destroyed by medium-grade metamorphism in most areas. Lower grade exposures in the Gospel Hump Wilderness (north margin, pl. 2) contain centimeter-scale climbing ripple lamination and load structures (Lund, 1984). Thickness about 3,200 m (Lund, 1984). May be in part equivalent to biotite gneiss unit (Ygn) and to biotite phyllite and calcareous phyllite of the Yellowjacket Formation (Yy)

\section{Undifferentiated metamorphic rocks}

ZYs Metamorphic rocks, undivided (Neoproterozoic? and Mesoproterozoic?) —Undivided metasedimentary rocks and minor metavolcanic rocks. Compositions include quartzite, feldspathic quartzite, calc-silicate gneiss, biotite gneiss, micaceous schist, and amphibolite. Mapped mostly as screens and schlieren in foliated tonalite (Ktf) and biotite granodiorite (Kgdf, extreme east edge pl. 1 and west edge pl. 2), where sheared, structurally dismembered, and strongly intruded; not subdivided into discrete map units. Also shown in southeastern parts of plate 2 where rocks in roof pendants were not remapped and subdivided. Only limited observations of these outcrops were made during this study and, from these observations, it is not possible to determine if these rocks are part of the Neoproterozoic or Mesoproterozoic sections 


\section{References Cited}

Aliberti, E.A., 1988, A structural, petrographic, and isotopic study of the Rapid River area and selected mafic complexes in the northwestern United States-Implications for the evolution of an abrupt island arc-continent boundary: Cambridge, Mass., Harvard University Ph.D. dissertation, 194 p.

Armstrong, R.L., Taubeneck, W.H., and Hales, P.L., 1977, Rb/ $\mathrm{Sr}$ and $\mathrm{K} / \mathrm{Ar}$ geochronometry of Mesozoic granitic rocks and their Sr isotopic composition, Oregon, Washington, and Idaho: Geological Society of America Bulletin, v. 88, p. $397-411$.

Ave Lallemant, H., Phelps, D.W., and Sutter, J.F., 1980, ${ }^{40} \mathrm{Ar} /{ }^{39} \mathrm{Ar}$ ages of some pre-Tertiary plutonic and metamorphic rocks of eastern Oregon and their geologic relationships: Geology, v. 8, p. 371-374.

Ave Lallemant, H.G., Schmidt, W.J., and Kraft, J.L., 1985, Major Late Triassic strike-slip displacement in the Seven Devils terrane, Oregon and Idaho-A result of left-oblique plate convergence?: Tectonophysics, v. 119, p. 299-328.

Balcer, D.E., 1980, ${ }^{40} \mathrm{Ar} /{ }^{39} \mathrm{Ar}$ ages and REE geochemistry of basement terranes in the Snake River Canyon, northeastern Oregon-western Idaho: Columbus, Ohio, The Ohio State University Master's thesis, $111 \mathrm{p}$.

Bishop, E.M., 1995, Mafic and ultramafic rocks of the Baker terrane, eastern Oregon, and their implications for terrane origin, in Vallier, T.L., and Brooks, H.C., eds., Geology of the Blue Mountains region of Oregon, Idaho, and Washington-Petrology and tectonic evolution of pre-Tertiary rocks of the Blue Mountains region: U.S. Geological Survey Professional Paper 1438, p. 221-246.

Brooks, H., 1979, Plate tectonics and the geologic history of the Blue Mountains: Oregon Geology, v. 41, p. 71-80.

Bruce, W., 1971, Geology, mineral deposits, and alteration of parts of the Cuddy Mountain District, western Idaho: Corvallis, Oreg., Oregon State University Ph.D. dissertation, $165 \mathrm{p}$.

Cater, F.W., Pinckney, D.M., Hamilton, W.B., Parker, R.L., Weldin, R.D., Close, T.J., and Zilka, N.T., 1973, Mineral resources of the Idaho Primitive Area and vicinity, Idaho: U.S. Geological Survey Bulletin 1304, 431 p.

Connor, J.J., 1990, Geochemical stratigraphy of the Yellowjacket Formation (Middle Proterozoic) in the area of the Idaho cobalt belt, Lemhi County, Idaho: U.S. Geological Survey Open-File Report 90-0234-A, 30 p.

Connor, J.J., 1991, Some geochemical features of the Blackbird and Jackass zones of the Yellowjacket Formation (Middle Proterozoic) in east-central Idaho: U.S. Geological Survey Open-File Report 91-0259, 25 p.
Connor, J.J., and Evans, K.V., 1986, Geologic map of the Leesburg quadgrangle, Lemhi County, Idaho: U.S. Geological Survey Miscellaneous Field Studies Map MF-1880, scale 1:62,500.

Cook, E.F., 1954, Mining geology of the Seven Devils Region: Idaho Bureau of Mines and Geology Pamphlet 97, 22 p.

Doughty, P.T., and Chamberlain, K.R., 1996, Salmon River Arch revisited-New evidence for 1370 Ma rifting near the end of deposition in the Middle Proterozoic Belt basin: Canadian Journal of Earth Science, v. 33, p. 1037-1052.

Ekren, E.B., 1988, Stratigraphic and structural relations of the Hoodoo Quartzite and Yellowjacket Formation of Middle Proterozoic age from Hoodoo Creek eastward to Mount Taylor, central Idaho, with a Geologic map of the region between the Middle Fork of the Salmon River and the Salmon River: U.S. Geological Survey Bulletin 1570, 17 p.

Evans, K.V., and Fischer, L.B., 1986, U/Pb geochronology of two augen gneiss terranes, Idaho-New data and tectonic implications: Canadian Journal of Earth Sciences, v. 23, p. 1919-1927.

Evans, K.V., and Zartman, R.E., 1990, U-Th-Pb and Rb-Sr geochronology of Middle Proterozoic granite and augen gneiss, Salmon River Mountains, east-central Idaho: Geological Society of America Bulletin, v. 102, p. 63-73.

Fisher, F.S., McIntyre, D.H., and Johnson, K.M., 1992, Geologic map of the Challis $1^{\circ} \times 2^{\circ}$ quadrangle, Idaho: U.S. Geological Survey Miscellaneous Investigations Series Map I-1819, scale 1:250,000.

Fitzgerald, J.F., 1982, Geology and basalt stratigraphy of the Weiser embayment, west-central Idaho, in Bonnichsen, B., and Breckenridge, R.M., eds., Cenozoic geology of Idaho: Idaho Bureau of Mines and Geology Bulletin 26, p. 103-128.

Follo, M.F., 1986, Sedimentology of the Wallowa terrane, northeastern Oregon: Cambridge, Mass., Harvard University Ph.D. dissertation, $292 \mathrm{p}$.

Follo, M.F., 1994, Sedimentology and stratigraphy of the Martin Bridge Limestone and Hurwal Formation (Upper Triassic to Lower Jurassic) from the Wallowa terrane, Oregon, in Vallier, T.L., and Brooks, H.C., eds., Geology of the Blue Mountains region of Oregon, Idaho, and Washington-Stratigraphy, physiography, and mineral resources of the Blue Mountains region: U.S. Geological Survey Professional Paper 1439, p. 1-27.

Frankhauser, R.E., 1969, Geology and mineralization of the southern Cuddy Mountains, Washington County, Idaho: Corvallis, Oreg., Oregon State University Master's thesis, $137 \mathrm{p}$. 
Getty, S.R., Selverstone, J., Wernicke, B.P., Jacobsen, S.B., Aliberti, E., and Lux, D.R., 1993, Sm-Nd dating of multiple garnet growth events in an arc-continent collision zone, northwestern U.S. Cordillera: Contributions to Mineralogy and Petrology, v. 115, p. 45-57.

Gualtieri, J.L., and Simmons, G.C., 1978, Preliminary geologic map of the Hells Canyon area, Idaho County, Idaho, and Wallowa County, Oregon: U.S. Geological Survey Open-File Report 78-805, scale 1:48:000.

Hamilton, W., 1963, Metamorphism in the Riggins region, western Idaho: U.S. Geological Survey Professional Paper 436, $95 \mathrm{p}$.

Hamilton, W., 1969, Reconnaissance geologic map of the Riggins quadrangle, west-central Idaho: U.S. Geological Survey Miscellaneous Geologic Investigations Series Map I-579, scale 1:125,000.

Henricksen, T.A., 1975, Geology and mineral deposits of the Mineral-Iron Mountain District, Washington County, Idaho, and of a metallized zone in western Idaho and eastern Oregon: Corvallis, Oreg., Oregon State University Ph.D. dissertation, $205 \mathrm{p}$.

Hooper, P.R., and Swanson, D.A., 1990, The Columbia River Basalt Group and associated volcanic rocks of the Blue Mountains province, in Walker, G.W., ed., Geology of the Blue Mountains region of Oregon, Idaho, and Washington-Cenozoic geology of the Blue Mountains region: U.S. Geological Survey Professional Paper 1437, p. 63-100.

King, J.R., 1971, The geology of the southeastern Cuddy Mountain district, western Idaho: Corvallis, Oreg., Oregon State University Master's thesis, 78 p.

Leonard, B.F., 1962, Old metavolcanic rocks of the Big Creek area, central Idaho, in Short papers in geology, hydrology, and topography: U.S. Geological Survey Professional Paper 450-B, p. B11-B15.

Leonard, B.F., 1963, Syenite complex older than the Idaho batholith, Big Creek quadrangle, central Idaho, in Short papers in geology, hydrology, and topography: U.S. Geological Survey Professional Paper 450-E, p. E93-E97.

Leonard, B.F., and Marvin, R., 1982, Temporal evolution of the Thunder Mountain caldera and related features, central Idaho, in Bonnichsen, B., and Breckenridge, R.M., eds., Cenozoic geology of Idaho: Idaho Bureau of Mines and Geology Bulletin 26, p. 23-41.

Livingston, D.C., 1932, A major overthrust in western Idaho and northeastern Oregon: Northwest Science, v. 6, p. 31-36.
Long, P.E., and Duncan, R.A., $1982,{ }^{40} \mathrm{Ar} /{ }^{39} \mathrm{Ar}$ ages of Columbia River Basalt from deep boreholes in south-central Washington: Rockwell Hanford Operations Report RHOBW-SA-233P, $11 \mathrm{p}$.

Lund, K., 1984, Tectonic history of a continent-island arc boundary, west-central Idaho: University Park, Penn., The Pennsylvania State University Ph.D. dissertation, 210 p.

Lund, K., Aleinikoff, J.N., Evans, K.V., and Fanning, C.M., 2003, SHRIMP U-Pb geochronology of Neoproterozoic Windermere Supergroup, central Idaho-Implications for rifting of western Laurentia and synchroneity of Sturtian glacial deposits: Geological Society of America Bulletin, v. 115 , no. 3, p. 349-372.

Lund, K., Kuntz, M.A., Manduca, C.A., Gammons, C.H., Evans, K.V., Tysdal, R.G., Winkler, G.R., and Connor, J.J., 1997, Geology of the western Salmon River Mountains, Valley and Idaho Counties, west-central Idaho: U.S. Geological Survey Miscellaneous Investigations Series Map I-2599, scale 1:100,000.

Lund, K., McCollough, W.F., and Price, E.H., 1993, Geologic map of the Slate Creek-John Day Creek area, Idaho County, Idaho: U.S. Geological Survey Miscellaneous Investigations Series Map I-2299, scale 1:50,000.

Manduca, C.C.A., 1988, Geology and geochemistry of the oceanic arc-continent boundary in the western Idaho batholith near McCall: Pasadena, Calif., California Institute of Technology Ph.D. dissertation, $272 \mathrm{p}$.

Manduca, C.A., Kuntz, M.A., and Silver, L.T., 1993, Emplacement and deformation history of the western margin of the Idaho batholith near McCall-Influence of a major terrane boundary: Geological Society of America Bulletin, v. 105, p. $749-765$.

Mann, G.M., 1989, Seismicity and Late Cenozoic faulting in the Brownlee Dam area, Oregon-Idaho-A preliminary report: U.S. Geological Survey Open-File Report 89-429, $46 \mathrm{p}$.

Mann, G.M., 1991, Geology and seismicity of the Pine Valley and Cuddy Mountain region, Oregon-Idaho: Hayward, Calif., California State University Master's thesis, 230 p.

McCollough, W.F., 1984, Stratigraphy, structure, and metamorphism of Permo-Triassic rocks along the western margin of the Idaho batholith, John Day Creek, Idaho: University Park, Penn., The Pennsylvania State University Master's thesis, $141 \mathrm{p}$. 
McKee, E.H., Hooper, P.R., and Kleck, W.D., 1981, Age of Imnaha basalt - Oldest basalt flows of the Columbia River Basalt Group: Isochron/West, v. 31, p. 31-33.

Nash, J.T., and Hahn, G.A., 1989, Stratabound Co-Cu deposits and mafic volcaniclastic rocks in the Blackbird mining district, Lemhi County, Idaho, in Boyle, R.W., Brown, A.C., Jefferson, C.W., Jowett, E.C., and Kirkham, R.V., eds., Sediment-hosted stratiform copper deposits: Geological Association of Canada Special Paper 36, p. 339-356.

Onasch, C.M., 1977, Structural evolution of the western margin of the Idaho batholith in the Riggins, Idaho area: University Park, Penn., The Pennsylvania State University Ph.D. dissertation, $196 \mathrm{p}$.

Onasch, C.M., 1987, Temporal and spatial relations between folding, intrusion, metamorphism, and thrust faulting in the Riggins area, west-central Idaho, in Vallier, T.L., and Brooks, H.C., eds., Geology of the Blue Mountains region of Oregon, Idaho, and Washington-The Idaho batholith and its border zone: U.S. Geological Survey Professional Paper 1436, p. 139-150.

Ross, C.P., 1933, The Thunder Mountain mining district, Valley County, Idaho: Economic Geology, v. 28, p. 587-601.

Ross, C.P., 1934, Geology and ore deposits of the Casto quadrangle, Idaho: U.S. Geological Survey Bulletin 854, 135 p.

Ross, C.P., 1938, The geology of part of the Wallowa Mountains: Oregon Department of Geology and Mineral Industries Bulletin 3, $74 \mathrm{p}$.

Schmidt, D.L., 1957, Petrography of the Idaho batholith in Valley County, Idaho: Seattle, Wash., University of Washington Ph.D. dissertation, $110 \mathrm{p}$.

Schmidt, D.L., 1964, Reconnaissance petrographic cross section of the Idaho batholith in Adams and Valley Counties, Idaho: U.S. Geological Survey Bulletin 1181-G, 50 p.

Selverstone, J., Wernicke, B.P., and Aliberti, E.A., 1992, Intracontinental subduction and hinged unroofing along the Salmon River suture zone, west central Idaho: Tectonics, v. 11, p. 124-144.

Shannon, S.S., Jr., and Reynolds, S.J., 1975, A brief geological survey of the East Thunder Mountain mining district, Valley Co., Idaho: Idaho Bureau of Mines and Geology Information Circular 29, 13 p.

Shenon, P.J., and Ross, C.P., 1936, Geology and ore deposits near Edwardsburg and Thunder Mountain, Idaho: Idaho Bureau of Mines and Geology Pamphlet 44, 45 p.
Skurla, S.J., 1974, The geology of the Sturgill Peak area, Washington County, Idaho: Corvallis, Oreg., Oregon State University Master's thesis, $98 \mathrm{p}$.

Slater, M.N., 1969, Geology and mineral deposits of the western Cuddy Mountain district, western Idaho: Corvallis, Oreg., Oregon State University Master's thesis, 82 p.

Snee, L.W., Lund, K., Sutter, J.F., Balcer, D.E., and Evans, K.V., 1995, $\mathrm{An}{ }^{40} \mathrm{Ar} /{ }^{39} \mathrm{Ar}$ chronicle of the tectonic development of the Salmon River suture zone, western Idaho, in Vallier, T.L., and Brooks, H.C., eds., Geology of the Blue Mountains region of Oregon, Idaho, and WashingtonPetrology and tectonic evolution of pre-Tertiary rocks of the Blue Mountains region: U.S. Geological Survey Professional Paper 1438, p. 517-540.

Streckeisen, A.L., 1973, Plutonic rocks-Classification and nomenclature recommended by the IUGS subcommission on the systematics of igneous rocks: Geotimes, v. 23, p. 26-30.

Tysdal, R.G., 2000a, Stratigraphy and depositional environments of Middle Proterozoic rocks, northern part of the Lemhi Range, Lemhi County, Idaho: U.S. Geological Survey Professional Paper 1600, $40 \mathrm{p}$.

Tysdal, R.G., 2000b, Revision of Middle Proterozoic Yellowjacket Formation, central Idaho: U.S. Geological Survey Professional Paper 1601-A, 13 p.

Tysdal, R.G., Evans, K.V., and Lund, K., 2000, Geologic map of the Blackbird Mountain quadrangle, Lemhi County, Idaho: U.S. Geological Survey Geologic Investigations Series I-2728, scale 1:24,000.

Vallier, T.L., 1967, The geology of part of the Snake River canyon and adjacent areas in northeastern Oregon and western Idaho: Corvallis, Oreg., Oregon State University Ph.D. dissertation, $267 \mathrm{p}$.

Vallier, T.L., 1977, The Permian and Triassic Seven Devils Group, western Idaho and northeastern Oregon: U.S. Geological Survey Bulletin 1437, 58 p.

Vallier, T.L., 1995, Petrology of pre-Tertiary igneous rocks in the Blue Mountains region of Oregon, Idaho, and Washington-Implications for the geologic evolution of a complex island arc, in Vallier, T.L., and Brooks, H.C., eds., Geology of the Blue Mountains region of Oregon, Idaho, and Washington-Petrology and tectonic evolution of Pre-Tertiary rocks of the Blue Mountains region: U.S. Geological Survey Professional Paper 1438, p. 125-210. 
Walker, N.W., 1982, Pre-Tertiary plutonic rocks in the Snake River canyon, Oregon/Idaho-Intrusive roots of a Permo-Triassic arc complex: Geological Society of America Abstracts with Programs, v. 14, no. 4, p. 242-243.

Walker, N.W., 1986, U/Pb geochronologic and petrologic studies in the Blue Mountains terrane, northeastern Oregon and westernmost central Idaho-Implications for pre-Tertiary tectonic evolution: Santa Barbara, Calif., University of California Ph.D. dissertation, 214 p.

Walker, N.W., 1989, Early Cretaceous initiation of post-tectonic plutonism and the age of the Connor Creek fault, northeastern Oregon: Geological Society of America Abstracts with Programs, v. 21, no. 5, p. 155.
Walker, N.W., 1995, Tectonic implications of U-Pb zircon ages of the Canyon Mountain Complex, Sparta complex, and related metaplutonic rocks of the Baker terrane, northeastern Oregon, in Vallier, T.L., and Brooks, H.C., eds., Geology of the Blue Mountains region of Oregon, Idaho, and Washington-Petrology and tectonic evolution of pre-Tertiary rocks of the Blue Mountains region: U.S. Geological Survey Professional Paper 1438, p. 247-270.

White, D.E., 1941, Geologic map of the Yellow Pine area, Valley County, Idaho: U.S. Geological Survey Strategic Minerals Investigations Preliminary Map, scale 1:48,000.

White, W.H., 1968, Plutonic rocks of the southern Seven Devils Mountains, Idaho: Corvallis, Oreg., Oregon State University Ph.D. dissertation, 177 p.

White, W.H., 1973, Flow structure and form of the Deep Creek stock, southern Seven Devils Mountains, Idaho: Geological Society of America Bulletin, v. 84, p. 199-210. 


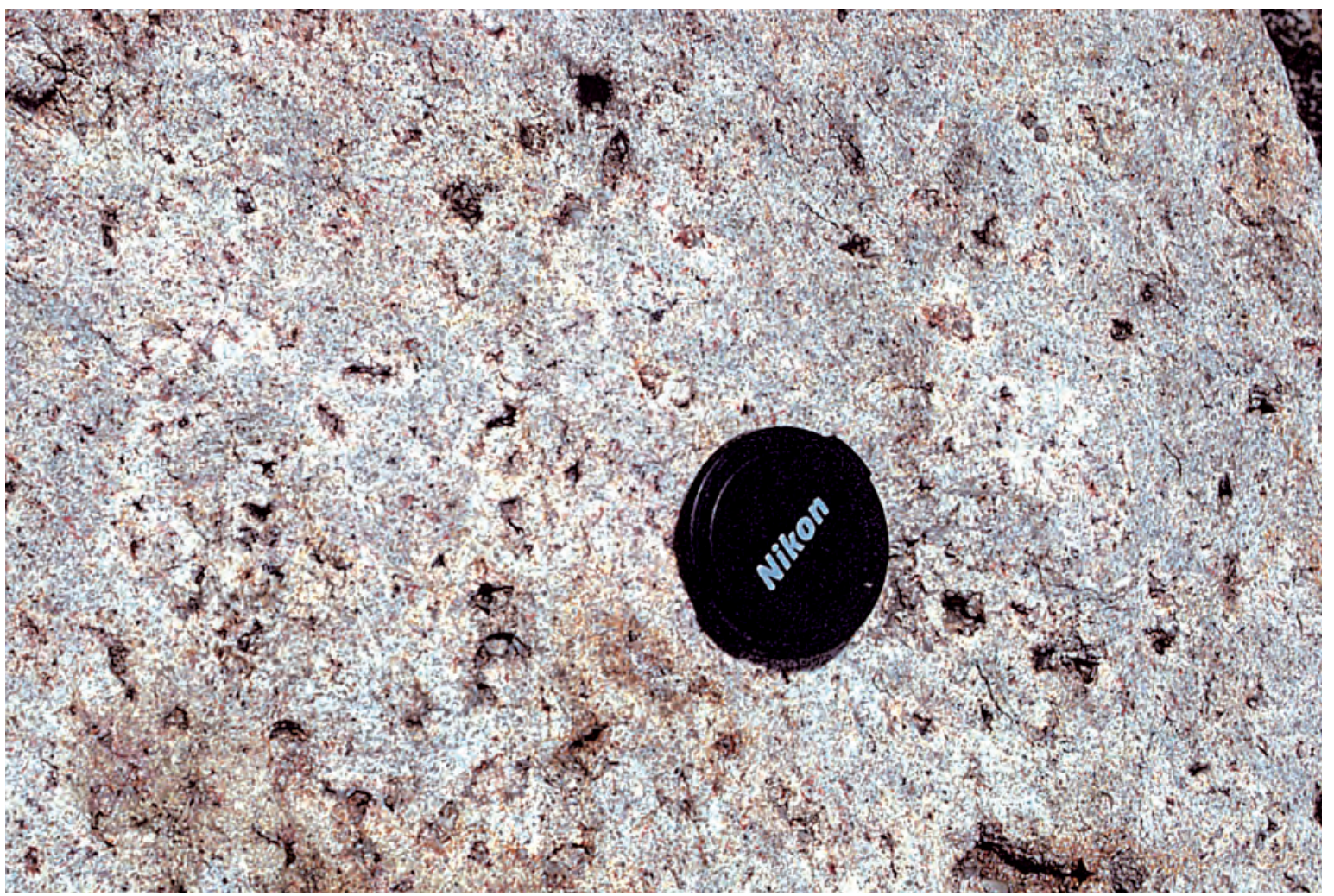

Figure B1 Eocene pink hornblende-biotite syenogranite porphyry (Tgp) containing abundant miarolitic cavities. Exposure at unnamed lake in upper Logan Creek drainage (central pl. 2). Lens cap $(7 \mathrm{~cm})$ for scale.

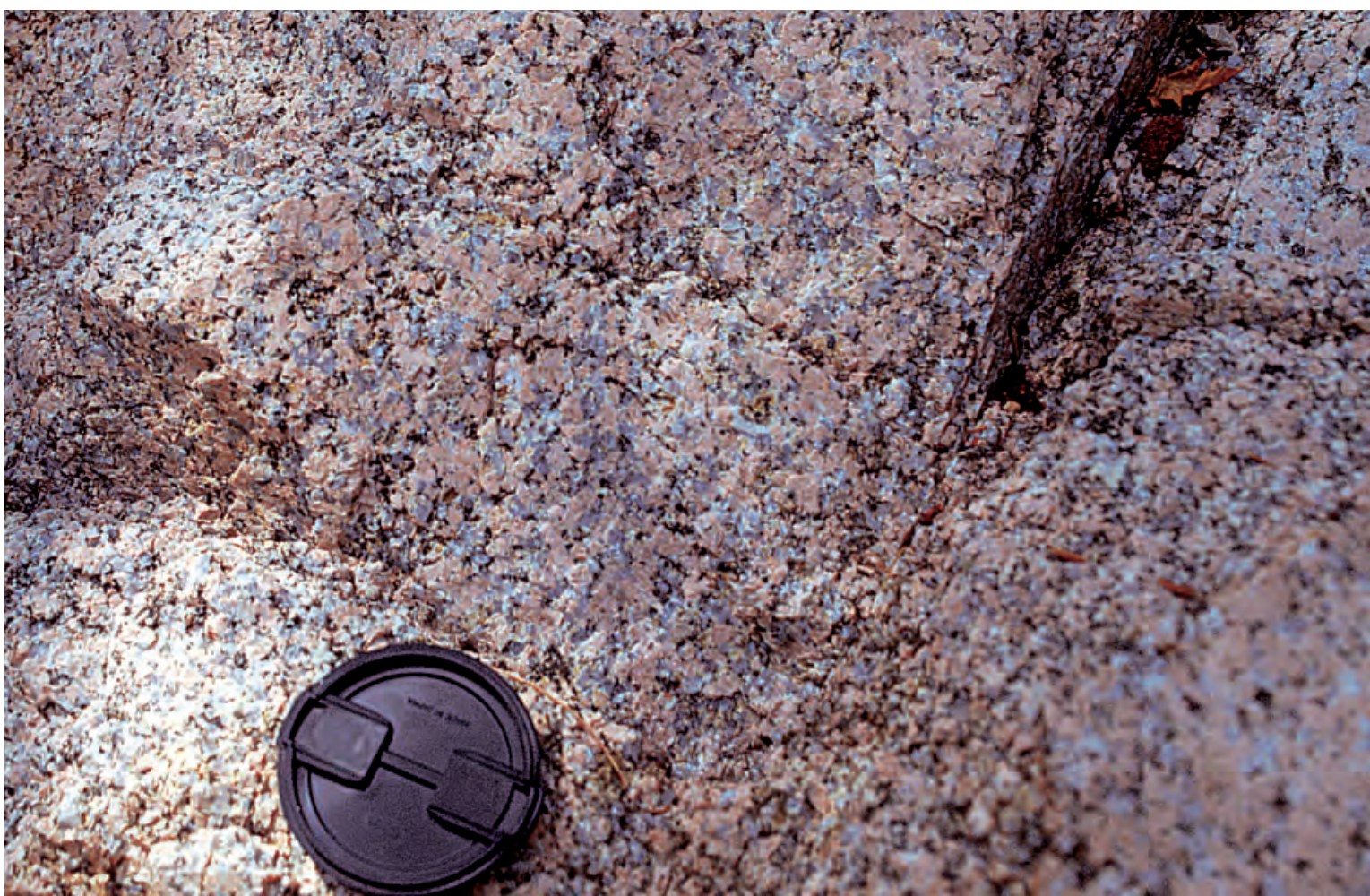

Figure B2. Eocene pink hornblende-biotite syenogranite (Tg). Exposure of Casto pluton from along Middle Fork Salmon River near White Creek (southeastern pl. 2). Lens cap $(7 \mathrm{~cm})$ for scale. 


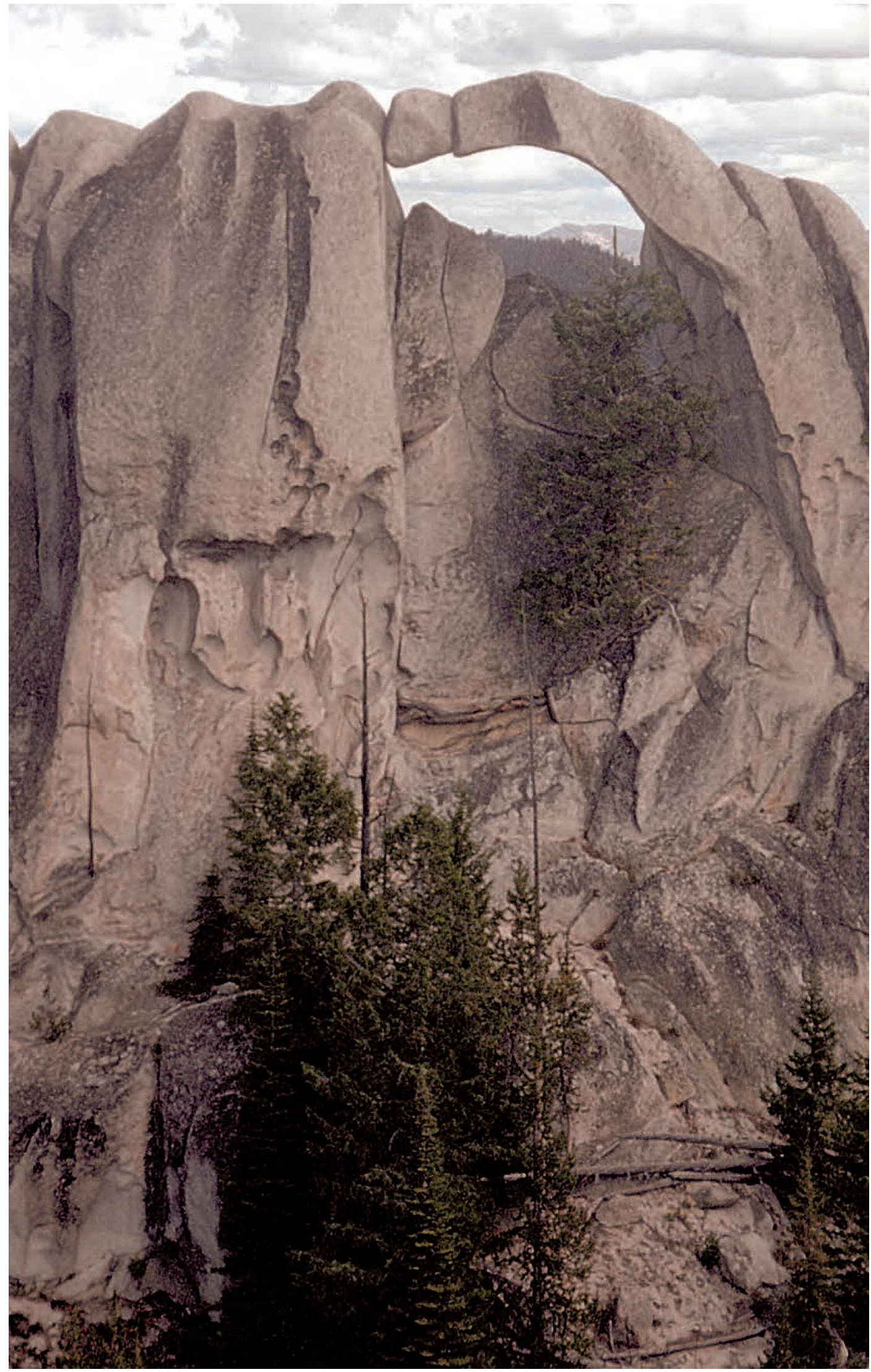

Figure B3. Rainbow arch cut in typical outcrops of Late Cretaceous biotite-muscovite granite (Kg). Location about $5 \mathrm{~km}$ south of Williams Peak (central pl. 2). 


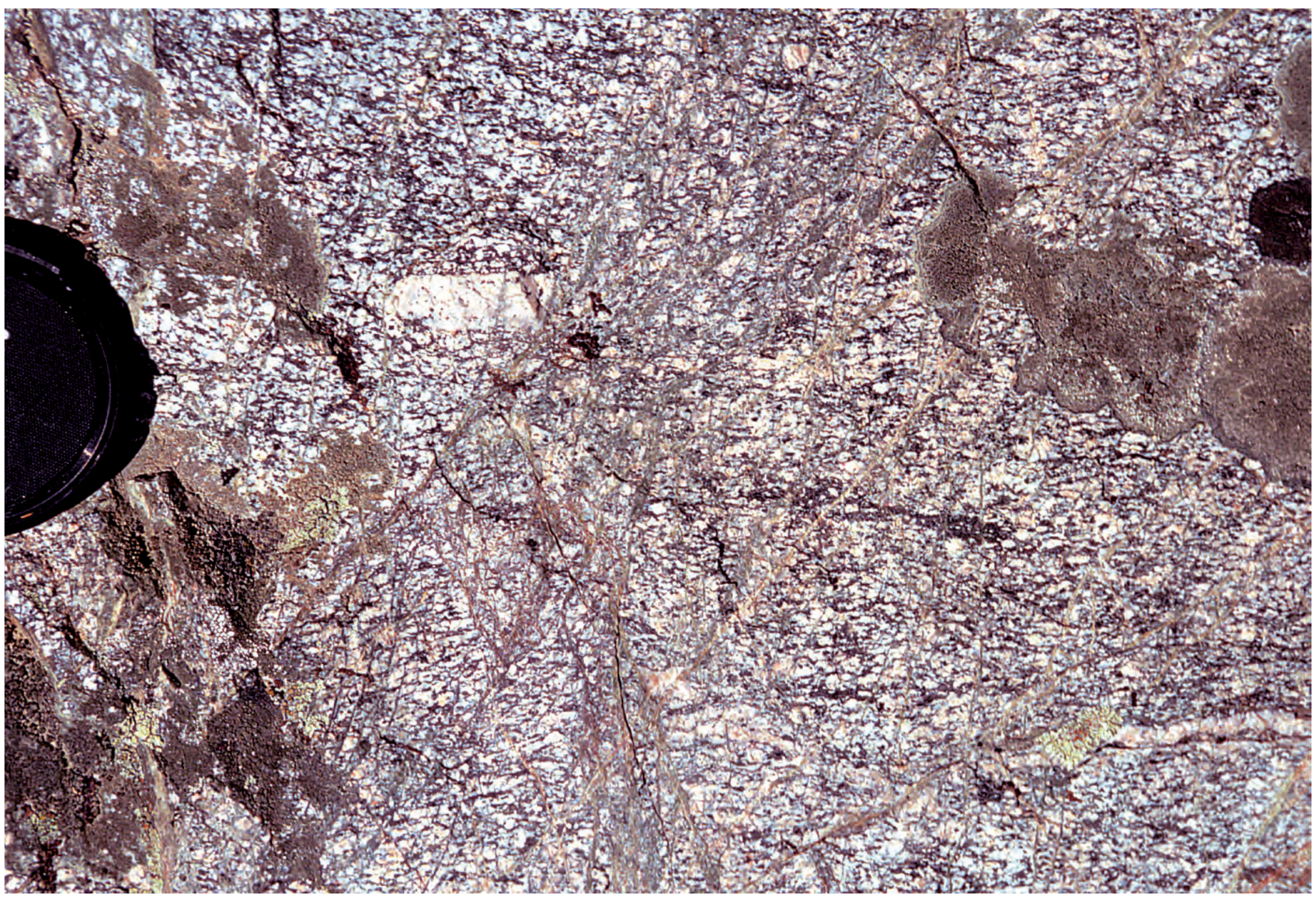

Figure B4. Late Cretaceous porphyritic biotite granodiorite containing large pink potassium feldspar phenocrysts (Kpgdf). Exposure along Middle Fork Salmon River near mouth of Camas Creek (south-central pl. 2). Lens cap $(7 \mathrm{~cm})$ for scale. 


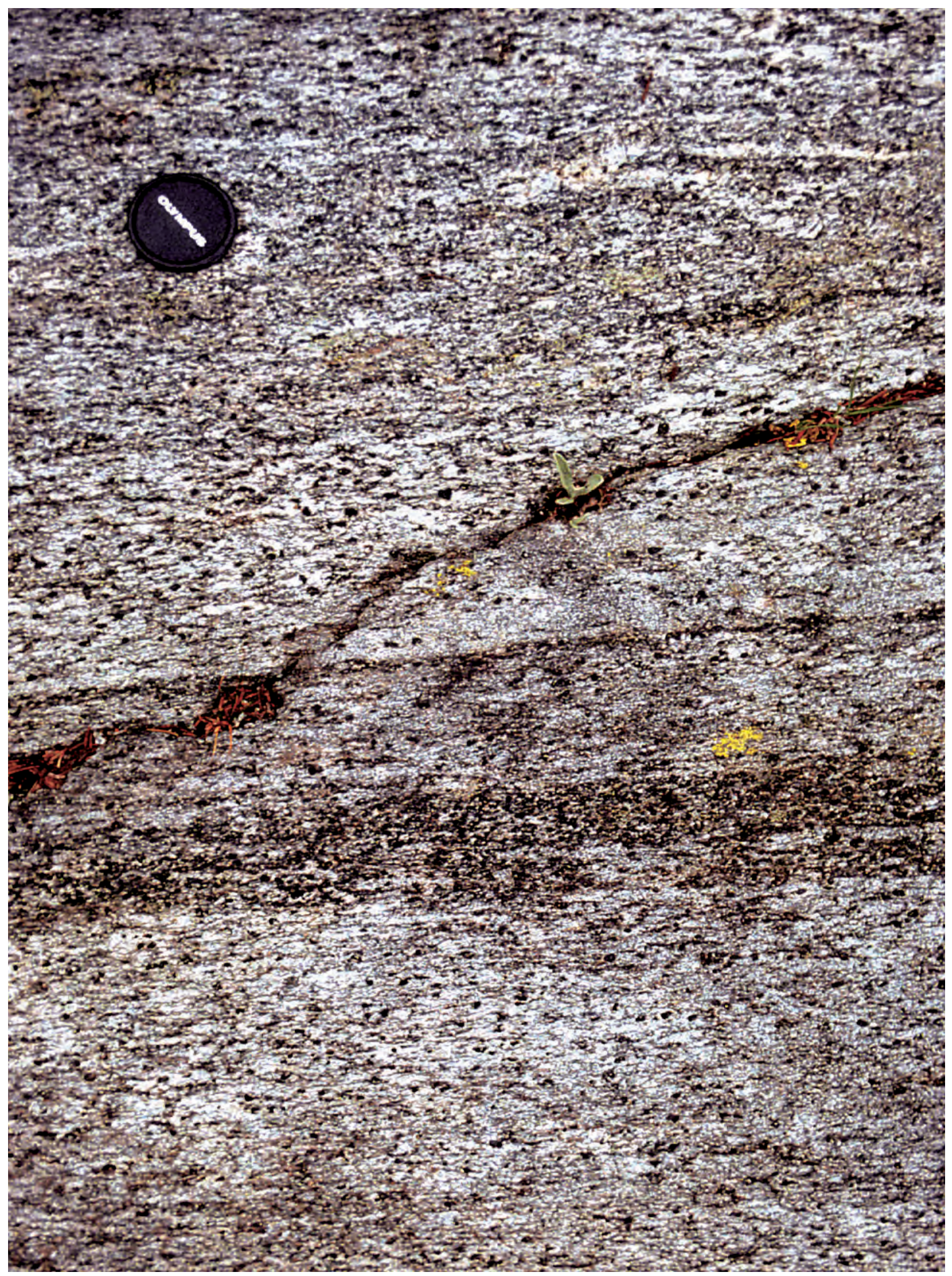

Figure B5. Cretaceous coarse-grained hornblende tonalite and mafic tonalite gneiss from heterogeneous orthogneiss complex (Kgn). Exposure about $2 \mathrm{~km}$ south of Hazard Lake (northeastern pl. 1). Lens cap (5.5 cm) for scale. 


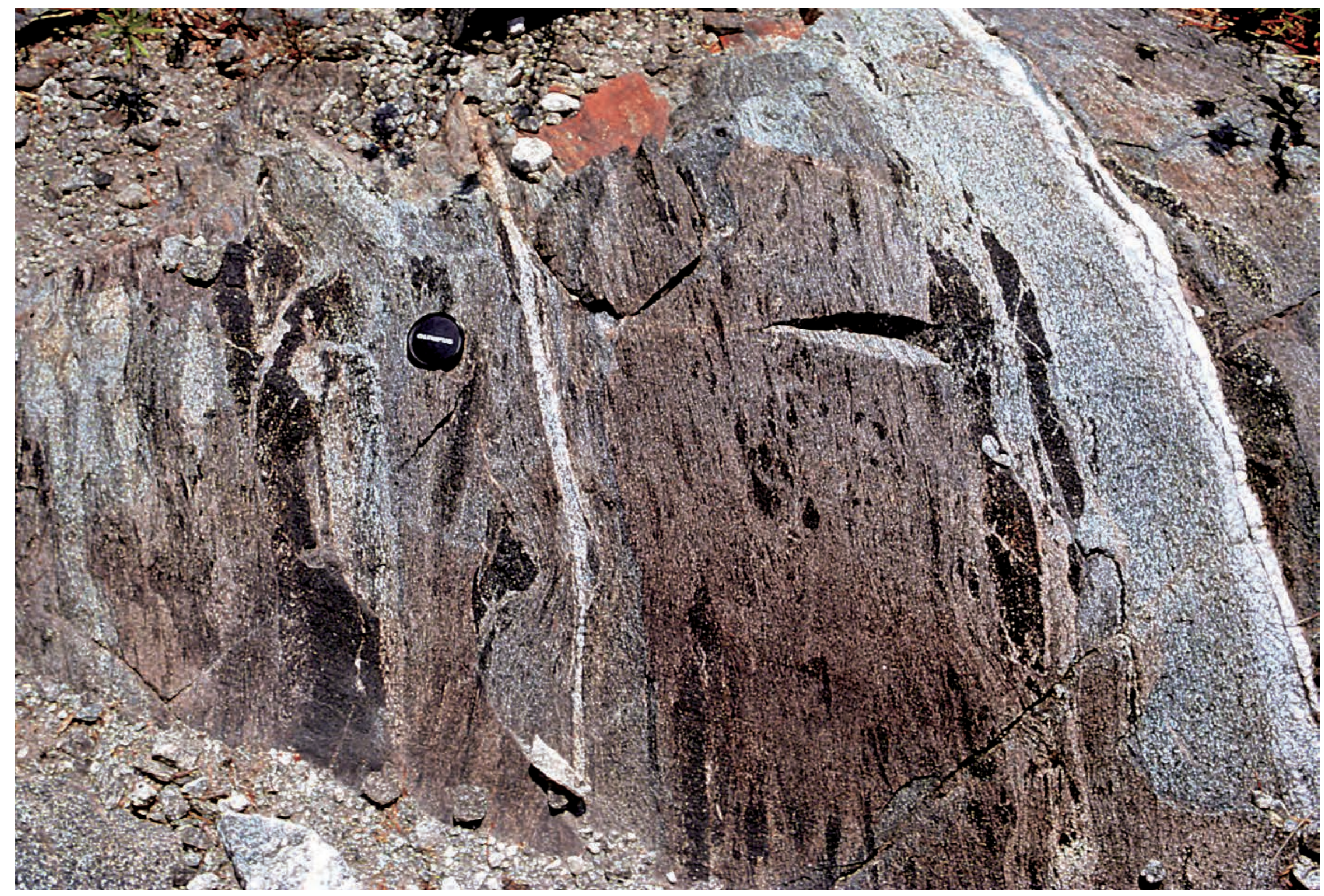

Figure B6. Heterogeneous mixture of Jurassic to Permian island-arc volcanic rocks and Cretaceous to Jurassic intrusive rocks in deformed metamorphosed volcanic/plutonic complex (KJPvp). Exposure east of Granite Lake (east-central pl. 1). Lens cap $(5.5 \mathrm{~cm})$ for scale. 

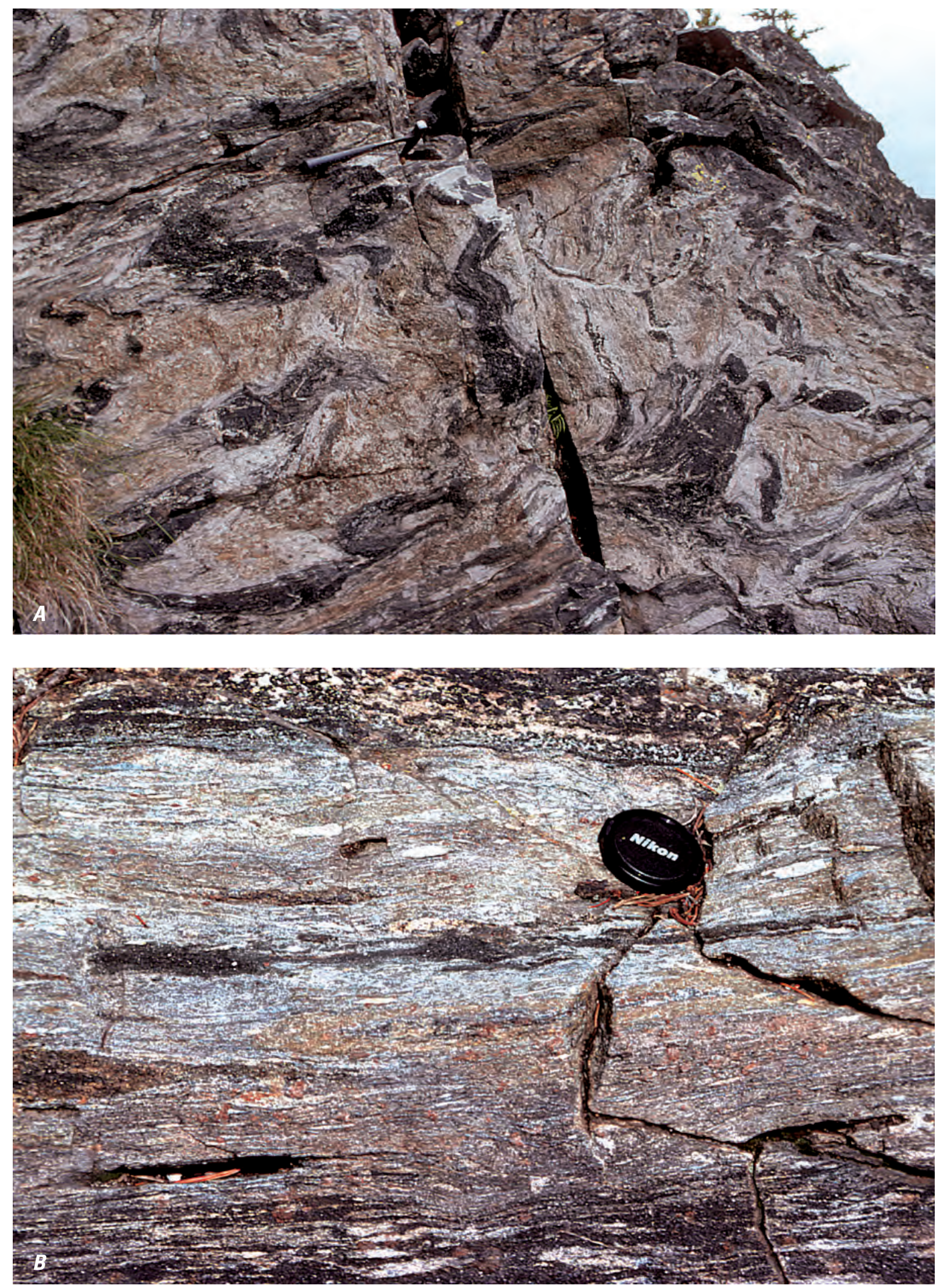

Figure B7. Deformed Jurassic to Permian amphibolite and garnet amphibolite gneiss (JPam). Unit is metamorphosed island-arc volcanic rock. A, Folded amphibolite gneiss from Pollock Mountain (northeastern pl. 1). Rock hammer (handle $30 \mathrm{~cm}$ ) for scale. B, Layered amphibolite gneiss containing probable stretched volcanic clasts and original compositional layering from Pollock Mountain. Lens cap $(7 \mathrm{~cm})$ for scale. 


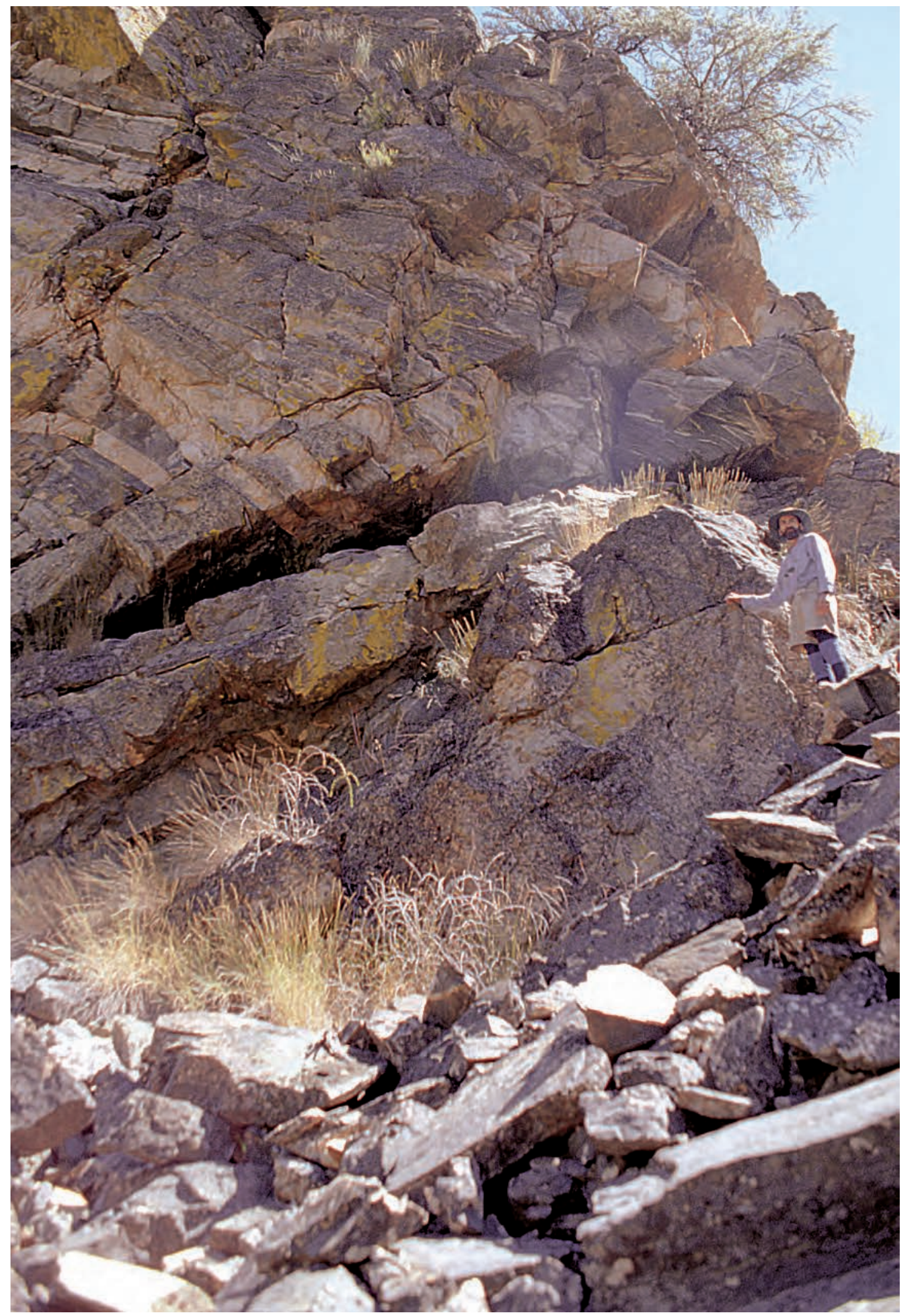

Figure B8. Contact between Mesoproterozoic granitic augen gneiss (Yagn beside geologist) and overlying Mesoproterozoic migmatitic biotite gneiss (Ygn); both units have parallel foliation indicating syn-intrusive or post-intrusive deformation. Exposure on lower Stoddard Creek (northeastern pl. 2). Undeformed Eocene dike intruded contact (1-m-thick zone crossing middle of exposure from above geologist's head to lower left). 

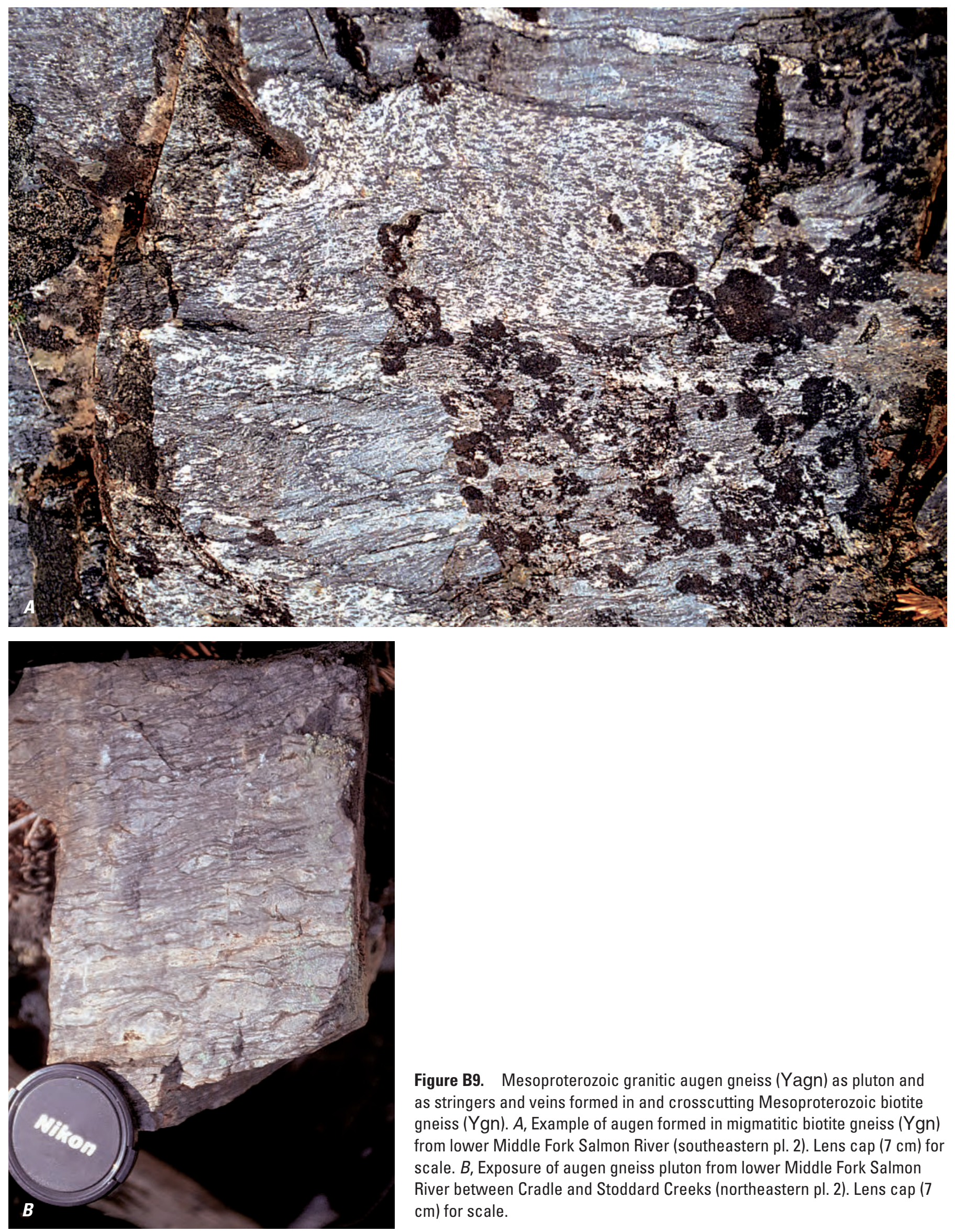

Figure B9. Mesoproterozoic granitic augen gneiss (Yagn) as pluton and as stringers and veins formed in and crosscutting Mesoproterozoic biotite gneiss (Ygn). A, Example of augen formed in migmatitic biotite gneiss (Ygn) from lower Middle Fork Salmon River (southeastern pl. 2). Lens cap (7 cm) for scale. $B$, Exposure of augen gneiss pluton from lower Middle Fork Salmon River between Cradle and Stoddard Creeks (northeastern pl. 2). Lens cap (7 $\mathrm{cm})$ for scale. 

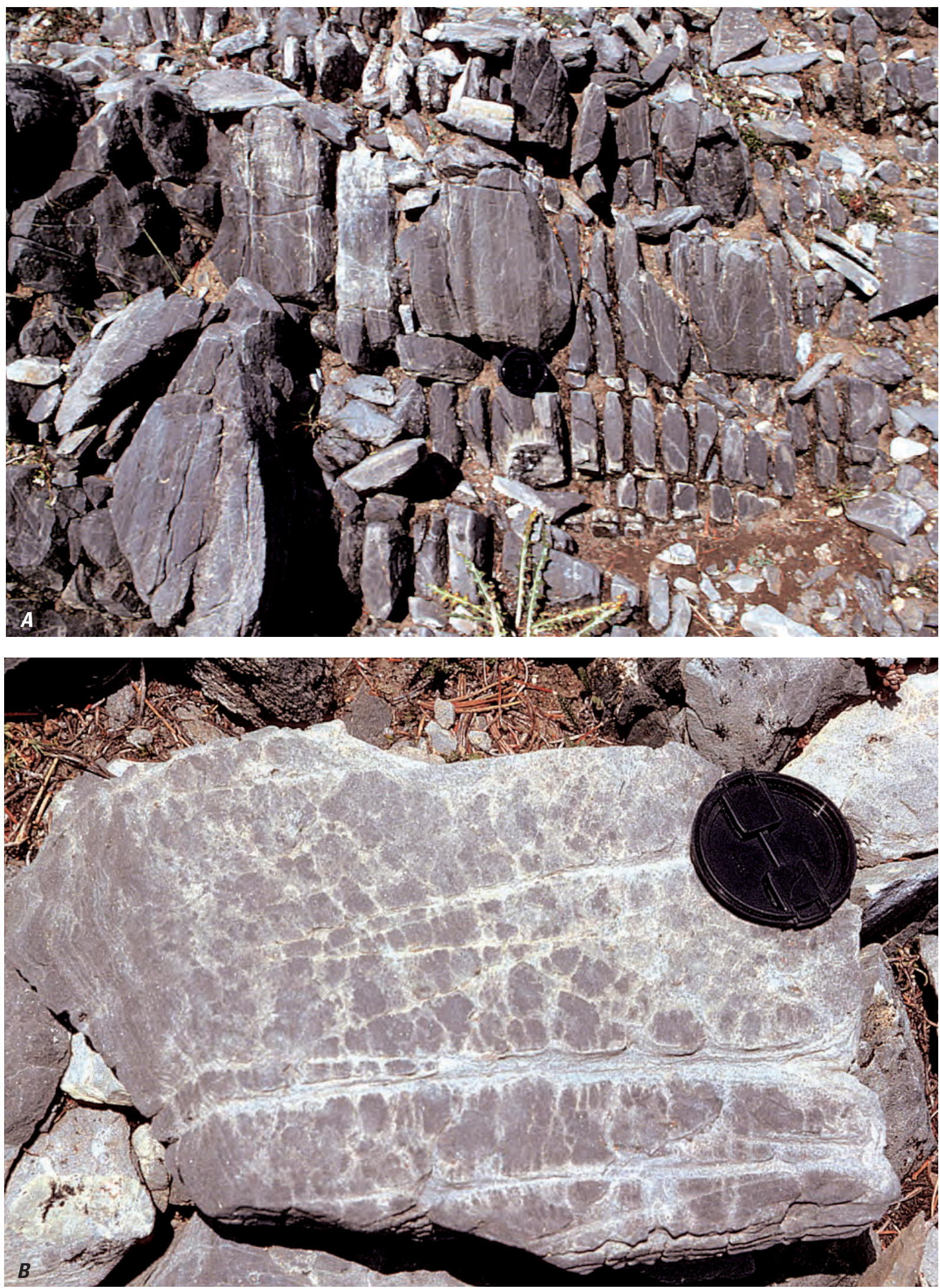

Figure B10. Cambrian or Neoproterozoic gray marble (€Zgm). Exposure on south side of Cinnabar Peak (central pl. 2). $A$, Example of layering that is probably original bedding. Leaves at bottom of photograph about $6 \mathrm{~cm}$ long. $B$, Bedding surface mottling. Lens cap $(7 \mathrm{~cm})$ for scale. 

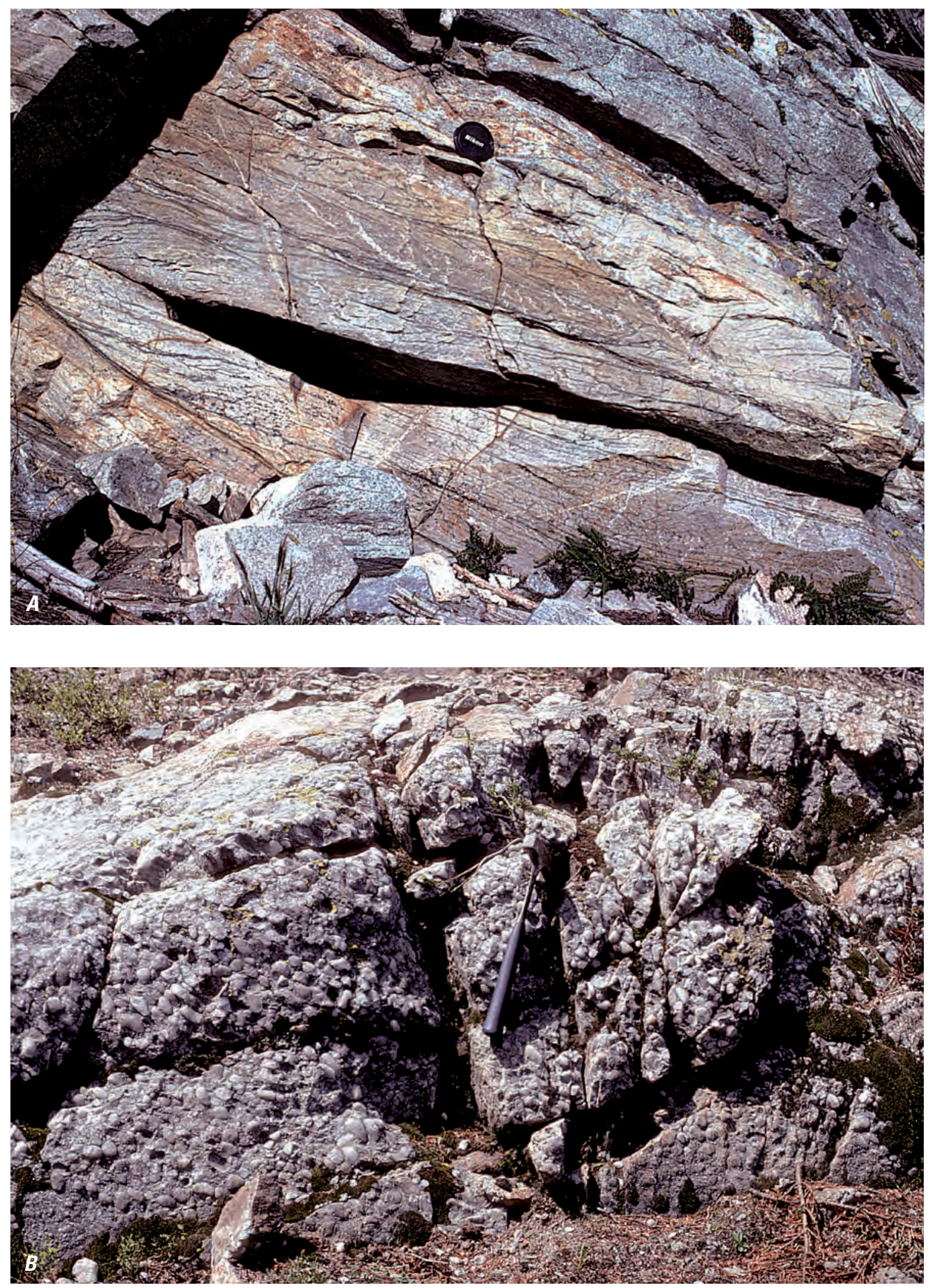

Figure B11 (above and facing page). Neoproterozoic quartzite and quartzite conglomerate of the Umbrella Butte Formation (€Zub). Exposures about $1 \mathrm{~km}$ northeast of Sugar Mountain (central pl. 2). A, Planar crossbed layers in arkosic quartzite. Lens cap $(7 \mathrm{~cm})$ for scale. $B$, Quartzite pebbles in quartzite conglomerate. Hammer (handle $30 \mathrm{~cm}$ ) for scale. C, Quartzite conglomerate interlayered with biotite schist, possibly overturned. Hammer (handle $30 \mathrm{~cm}$ ) for scale. 


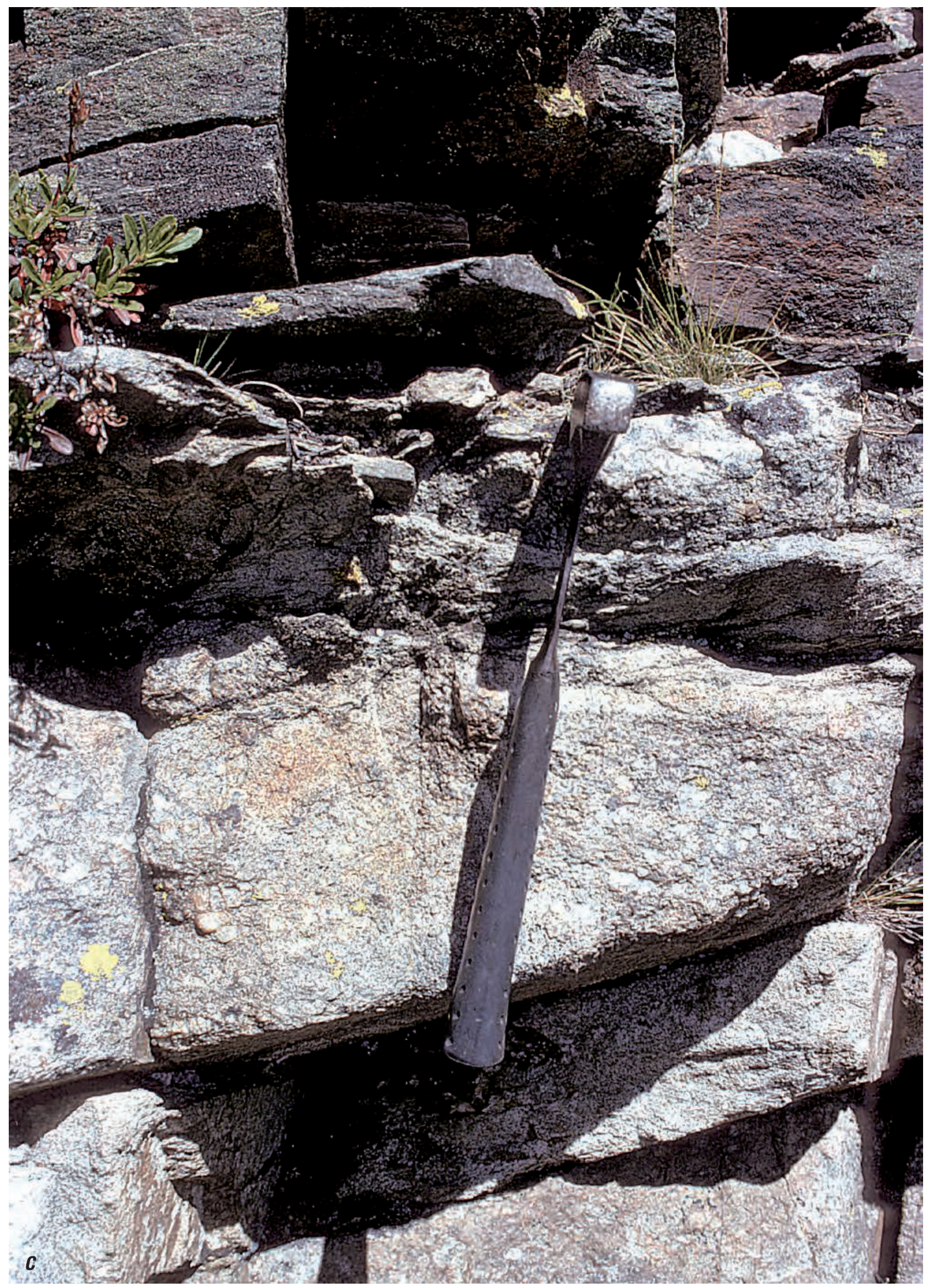




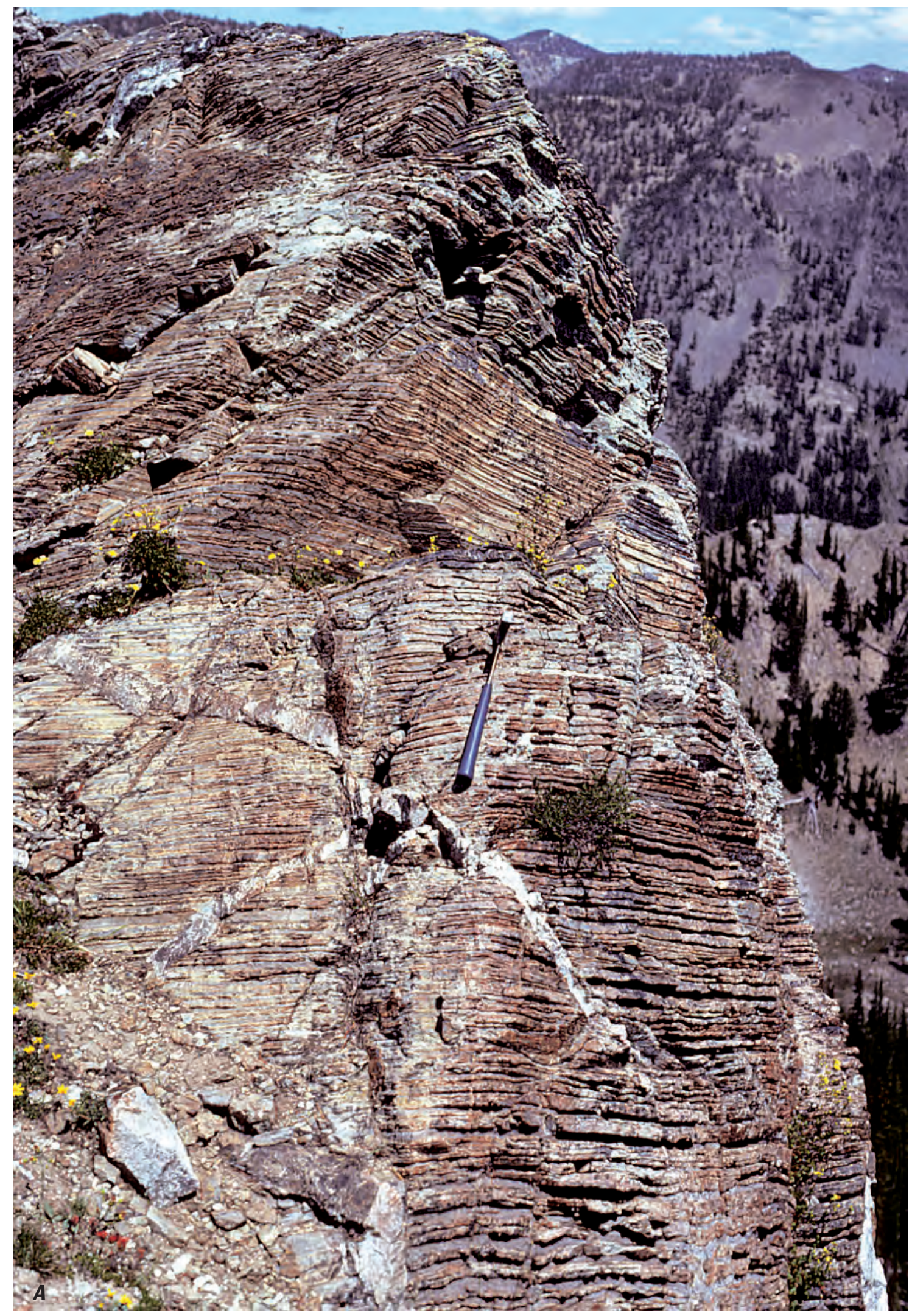

Figure B12 (above and facing page). Cambrian(?) and Neoproterozoic Missouri Ridge Formation (Zmr). $A$, Ribbon-laminated marble and calc-silicate metasiltite from Missouri Ridge (center pl. 2). Hammer (handle $30 \mathrm{~cm}$ ) for scale. $B$, Calc-silicate metasiltite with primary bedding from east side upper Missouri Creek. Lens cap $(7 \mathrm{~cm})$ for scale. 


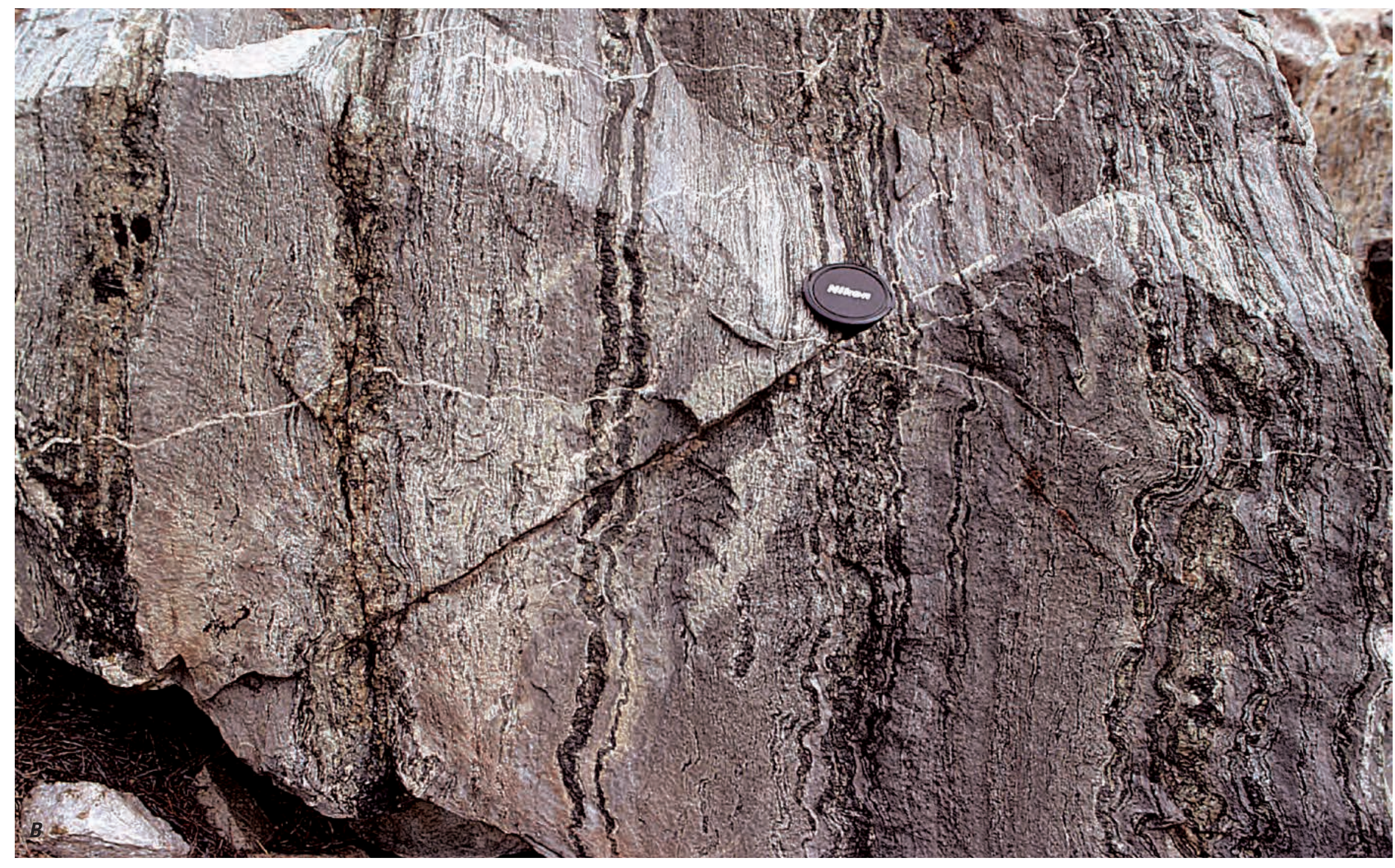

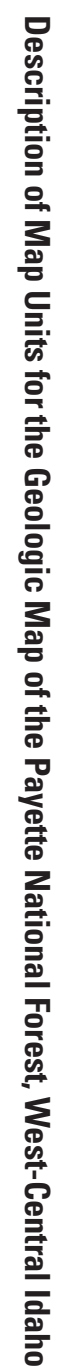




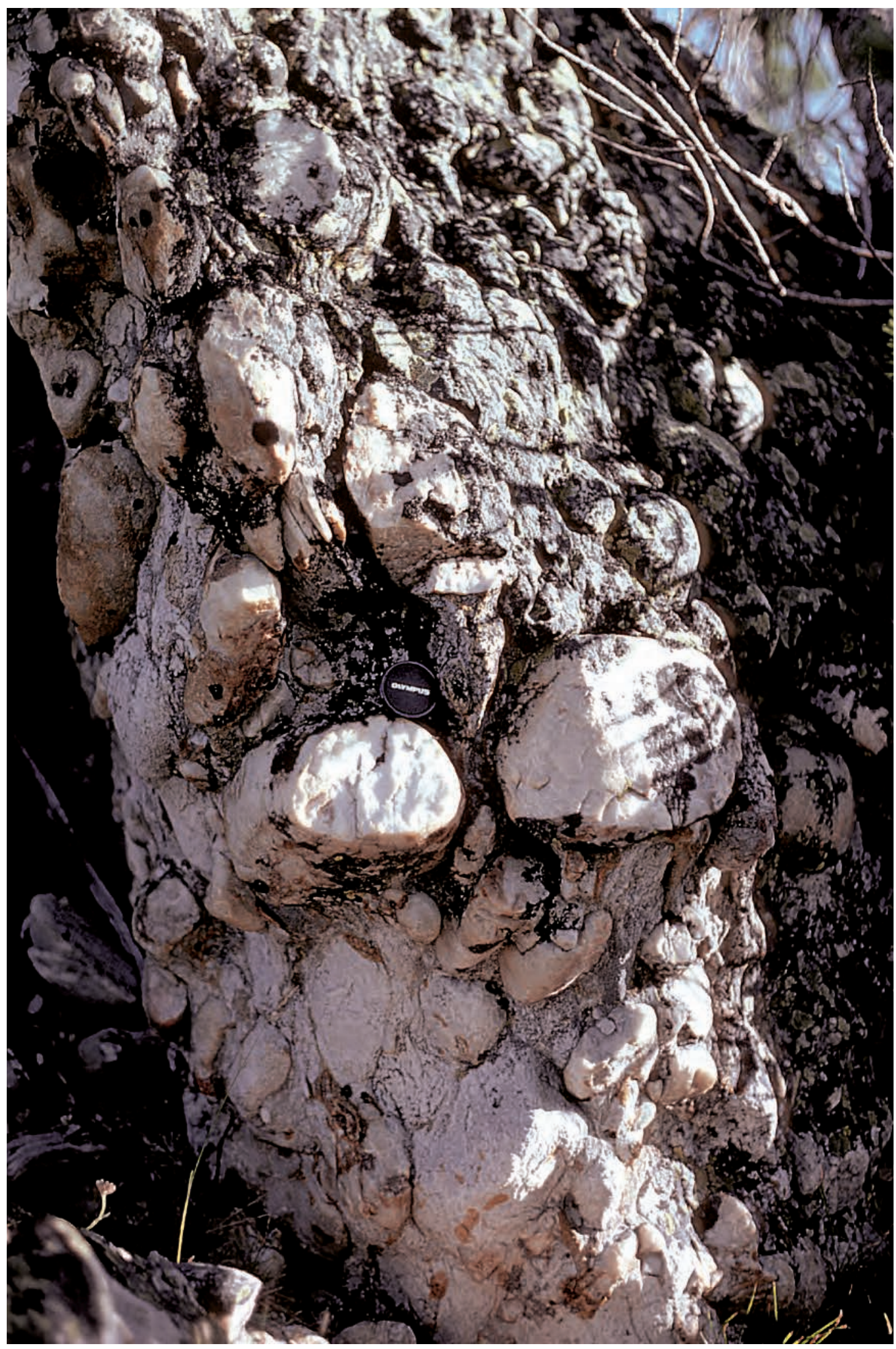

Figure B13. Neoproterozoic quartzite pebble to cobble conglomerate of the Moores Lake Formation $(Z \mathrm{ml})$. Exposure in upper Wind River drainage, Gospel Peak roof pendant, north of forest (location 2, fig. A6, northwest corner pl.2). Lens cap $(5.5 \mathrm{~cm})$ for scale. 


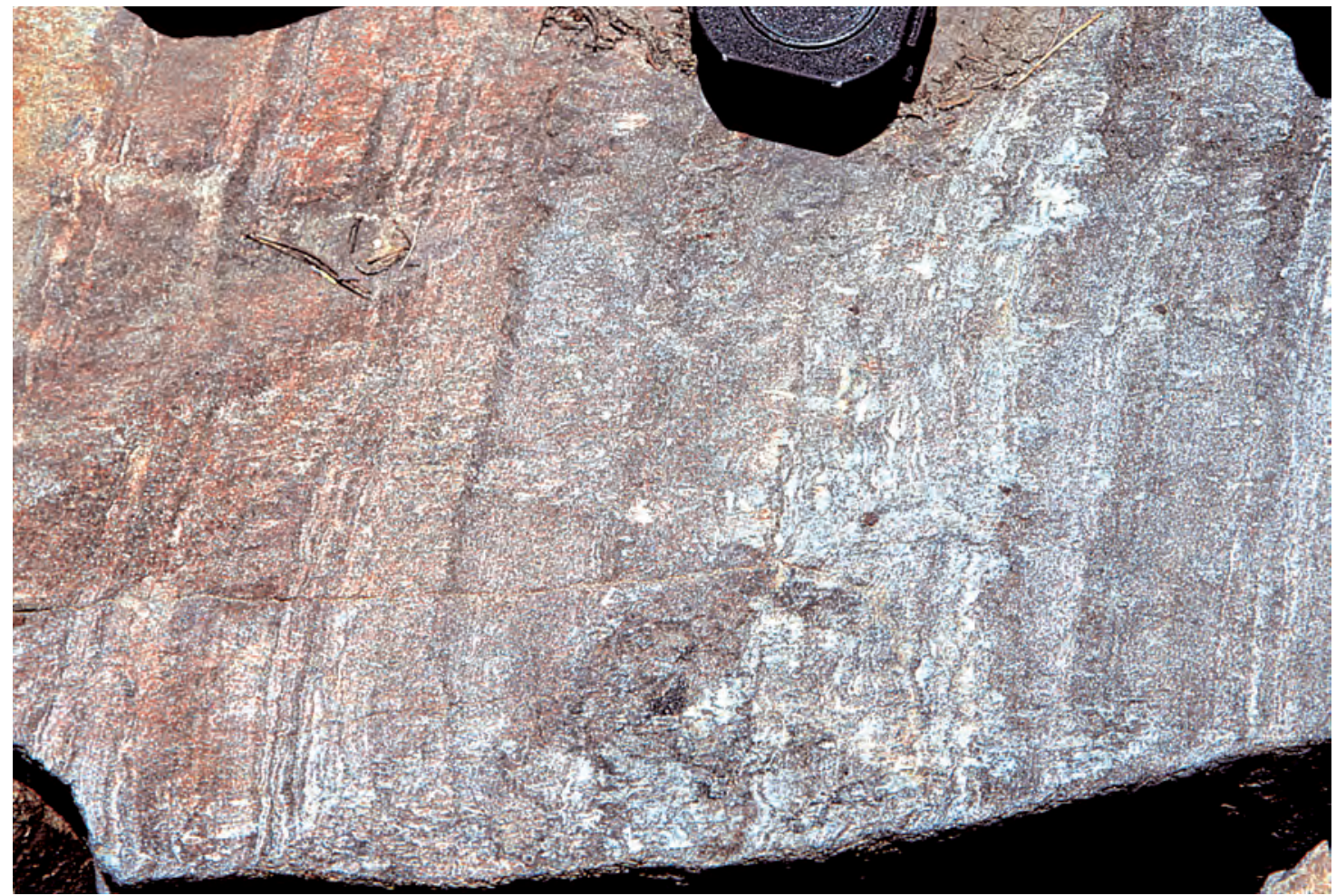

Figure B14. Feldspathic, staurolite-bearing, fine-grained metasandstone-schist of the Neoproterozoic Goldman Cut Formation (Zgc). Exposure near Goldman Cut, Big Creek roof pendant (central pl. 2). Compass $(7 \mathrm{~cm})$ for scale.

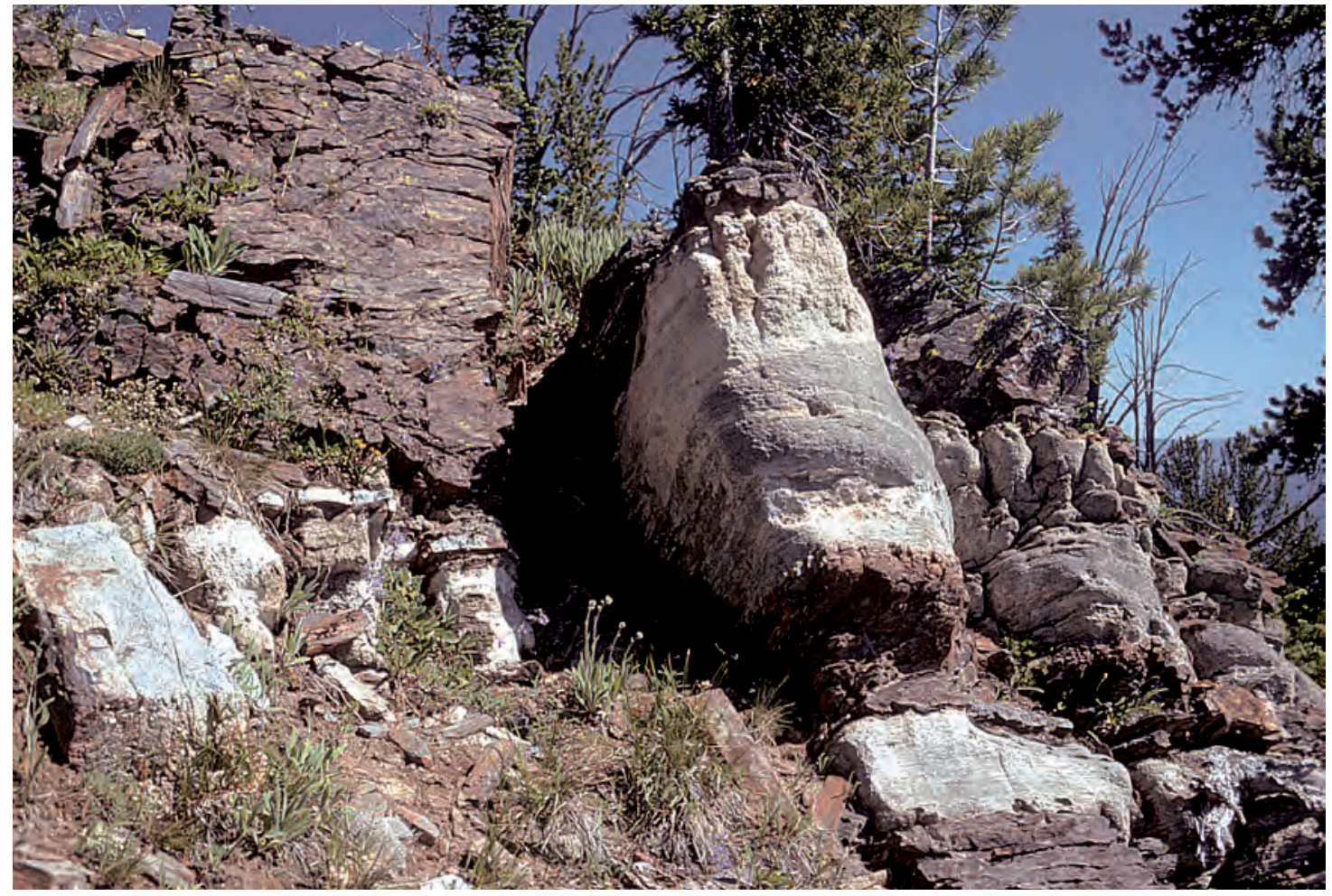

Figure B15. Interbedded light-gray marble, reddish-brown apatite-pyrite quartzite iron-formation, and metasiltite of the Neoproterozoic Moores Station Formation (Zms). Exposure in upper Bear Creek of Marshall Mountain roof pendant (fig. A3; northwestern pl. 2). Layers offset by down-to-the-left steep fault in middle of photograph. Flower stalks in lower middle of photograph about $30 \mathrm{~cm}$ high. 

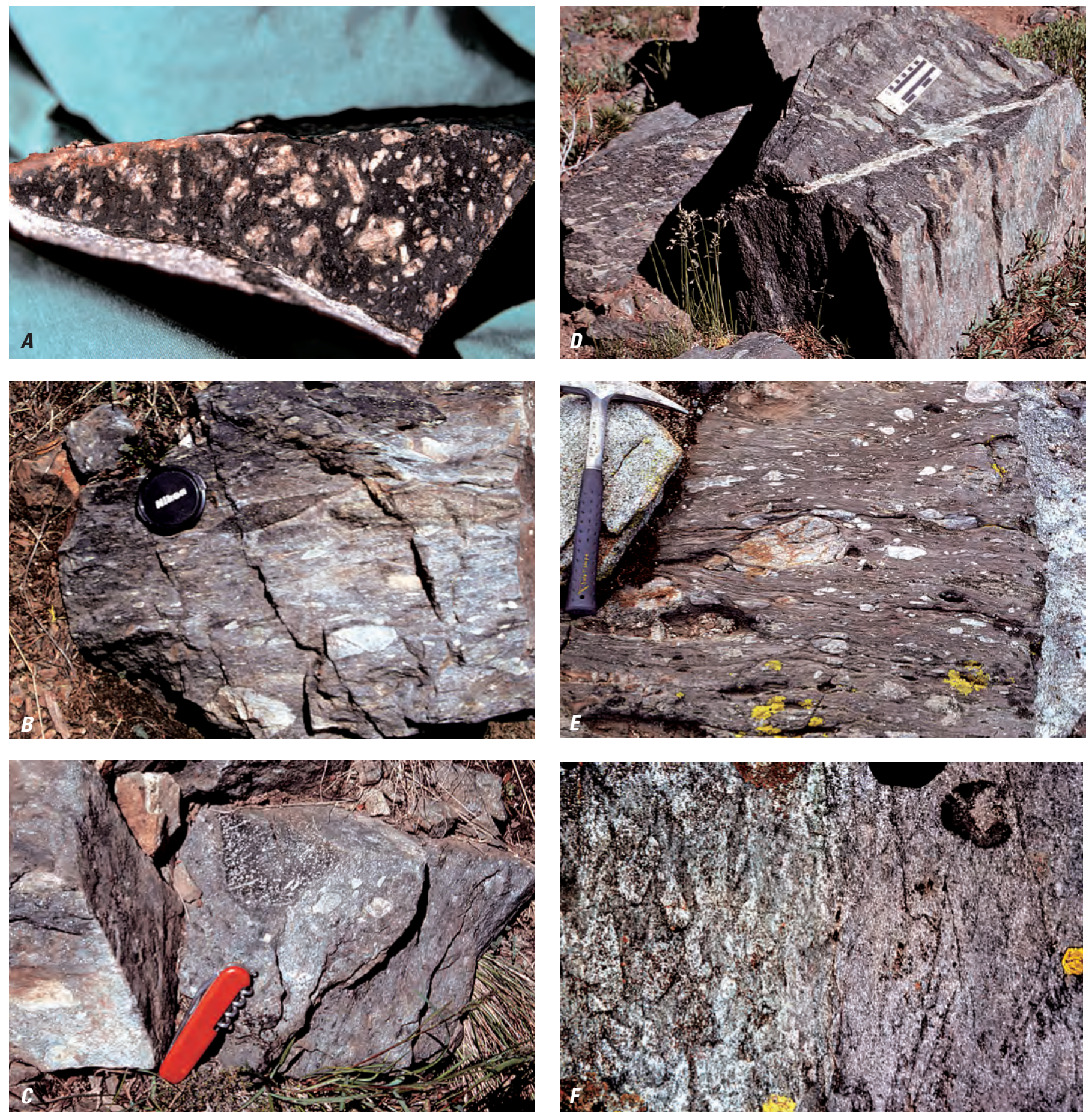

Figure B16. Neoproterozoic metavolcanic rocks, metavolcanogenic sedimentary rocks, and diamictites of the Edwardsburg Formation (Ze). A, Metamorphosed Hogback Rhyolite Member porphyry from hogback in lower Big Creek (center pl. 2). Sample about $16 \mathrm{~cm}$ long. $B$, Metamorphosed conglomerate of the Placer Creek Member with volcanogenic matrix and stretched pebbles consisting of various volcanic, quartzite, and calc-silicate gneiss compositions from ridge northwest of Big Creek. Lens cap (7 cm) for scale. $C$, Metamorphosed volcanic conglomerate of the Placer Creek Member with heterogeneous mixture of volcanic clast compositions from ridge northwest of Big Creek. Knife $(9 \mathrm{~cm})$ for scale. Photograph by P.K. Link. D, Mafic metavolcanic rock of the Golden Cup Member with stretched amygdules, many of which contain carbonate from ridge northwest of Big Creek. Scale bar $10 \mathrm{~cm}$ long. Photograph by R.G. Tysdal. E, Matrix-supported metamorphosed graywacke with quartzite and calc-silicate gneiss cobbles and pebbles from the Wind River Meadows Member near base of unit northwest of Big Creek. Hammer (handle $30 \mathrm{~cm}$ ) for scale. F, Metamorphosed rhyodacite flow breccia or reworked tuff with stretched rhyodacite pebbles from the Wind River Meadows Member from ridge west of Big Creek. Edge of compass $(5 \mathrm{~cm}$ in view) for scale. 

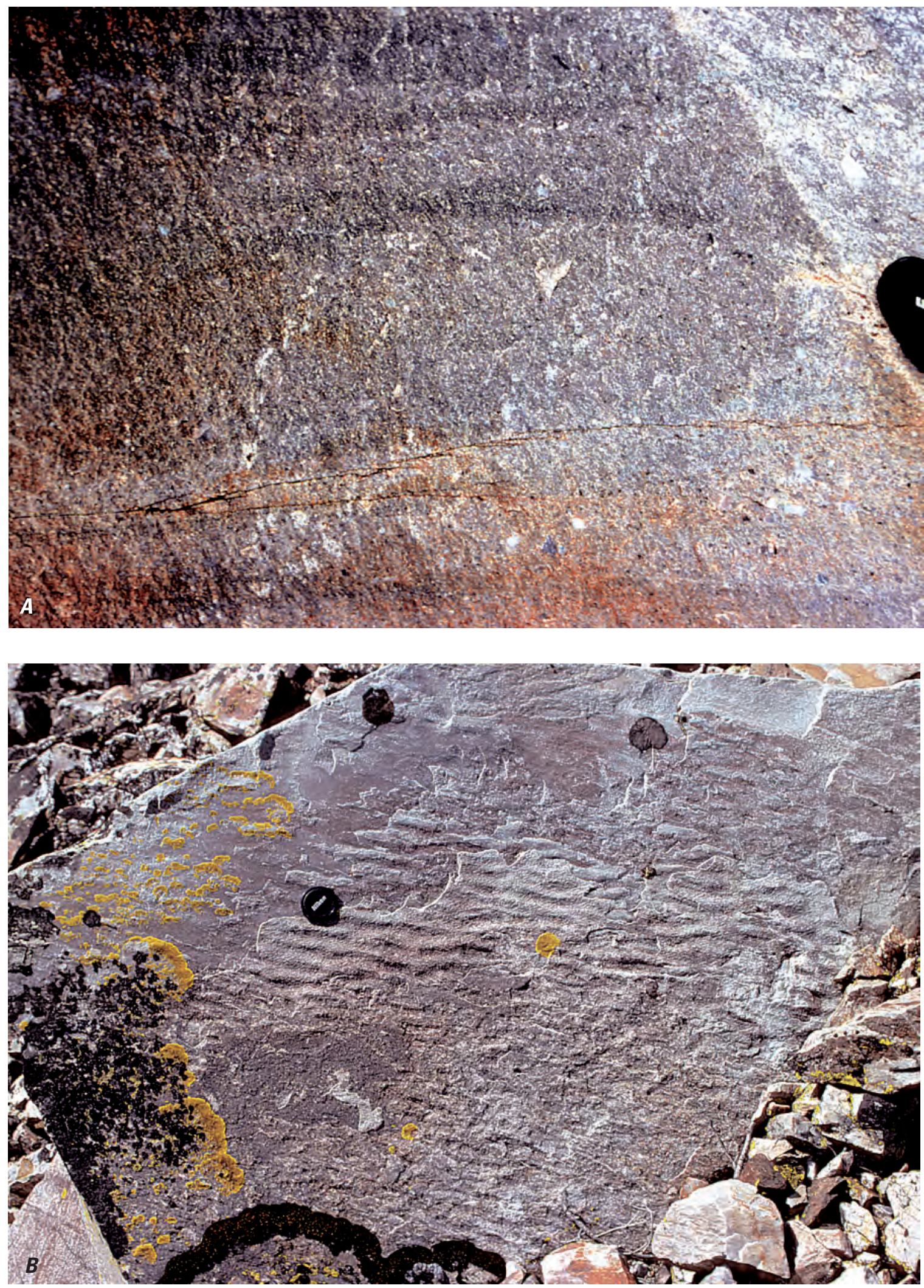

Figure B17. Neoproterozoic Square Mountain Formation (Zsm). A, Bimodal grain size includes granules of quartz and iron oxide from $3 \mathrm{~km}$ northwest of Big Creek (center pl. 2). Lens cap $(7 \mathrm{~cm}$ ) for scale. B, Straight-crested ripple marks from exposures from point of ridge $2 \mathrm{~km}$ south of mouth of North Fork of Smith Creek (center of pl. 2). Hammer (handle $30 \mathrm{~cm}$ ) for scale. 

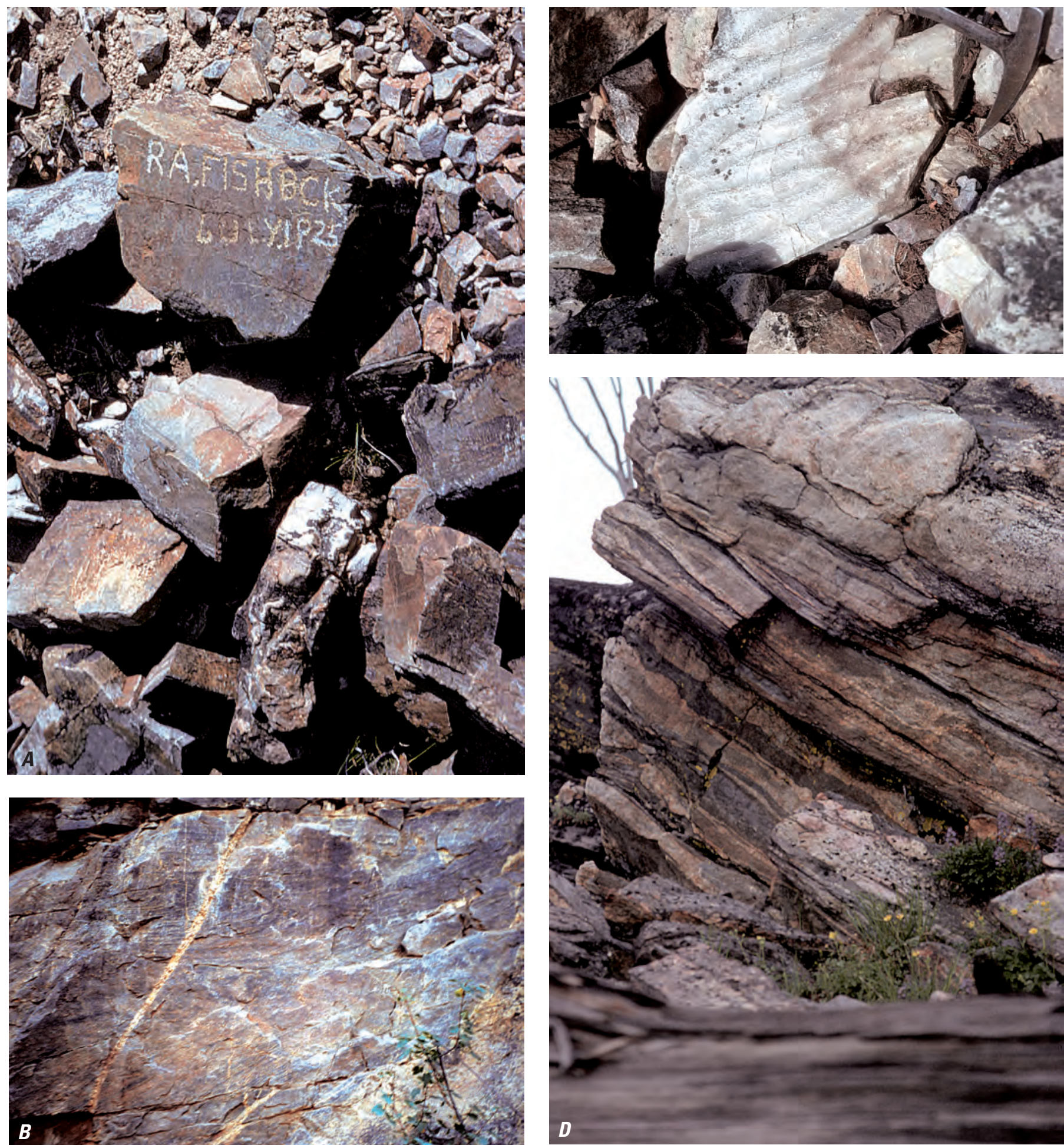

Figure B18. Mesoproterozoic biotite-feldspar-quartz metasandstone of the Gunsight Formation (Ylg). A, Fine-grained metasandstone layers alternate with biotite phyllite layers, shown in side view in block below carved block, from Center Mountain (center pl. 2). Carved letters about $3 \mathrm{~cm}$ high for scale. $B$, Crossbedding, soft-sediment deformation, and parallel bedding in exposures along Profile Creek (center pl. 2) from the Gunsight-Swauger transition. Plant $(10 \mathrm{~cm})$ for scale. $C$, Ripple-marked bedding surface from exposure along Big Creek about $3 \mathrm{~km}$ west of mouth of Ramey Creek (center of pl. 2). Hammer (head $18 \mathrm{~cm}$ ) for scale. D, High-grade metamorphism and litpar-lit injection zone in Mesoproterozoic biotite-feldspar quartz metasandstone (Ybfq) probably correlative with the Gunsight Formation, from Marshall Mountain (northwestern pl. 2). Flower stalks about $20 \mathrm{~cm}$ high. 

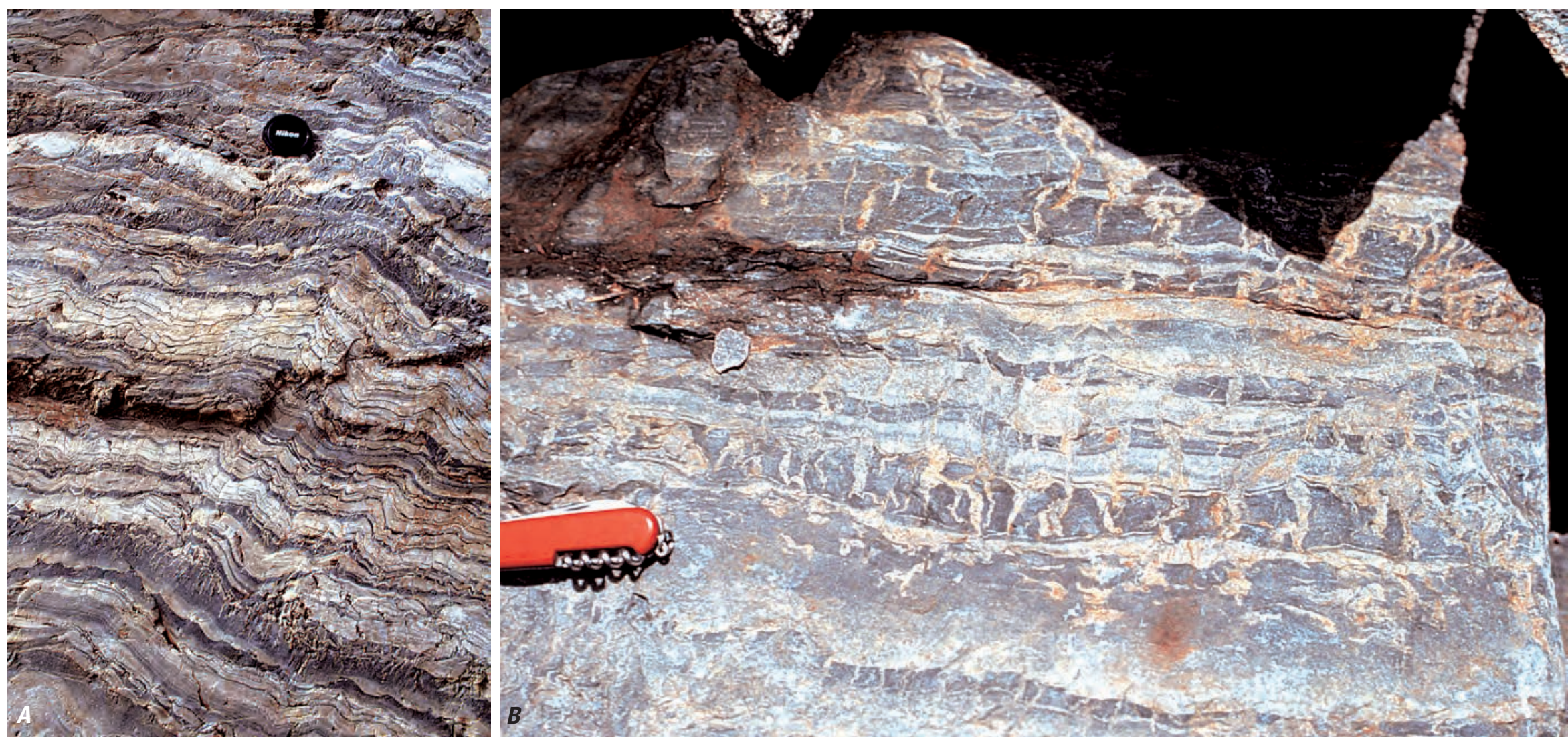

Figure B19. Mesoproterozoic laminated biotite phyllite and fine-grained metasandstone to siltite of the Apple Creek Formation (Ylau). Exposures at mouth of Smith Creek

(center pl. 2). A, Preserved graded bedding and water-escape structures. Superimposed cleavage planes from lower left to upper right of outcrop. Lens cap (7 cm) for scale. $B$ Close-up of graded bedding and water-escape structures. Knife $(8.5 \mathrm{~cm})$ for scale. 

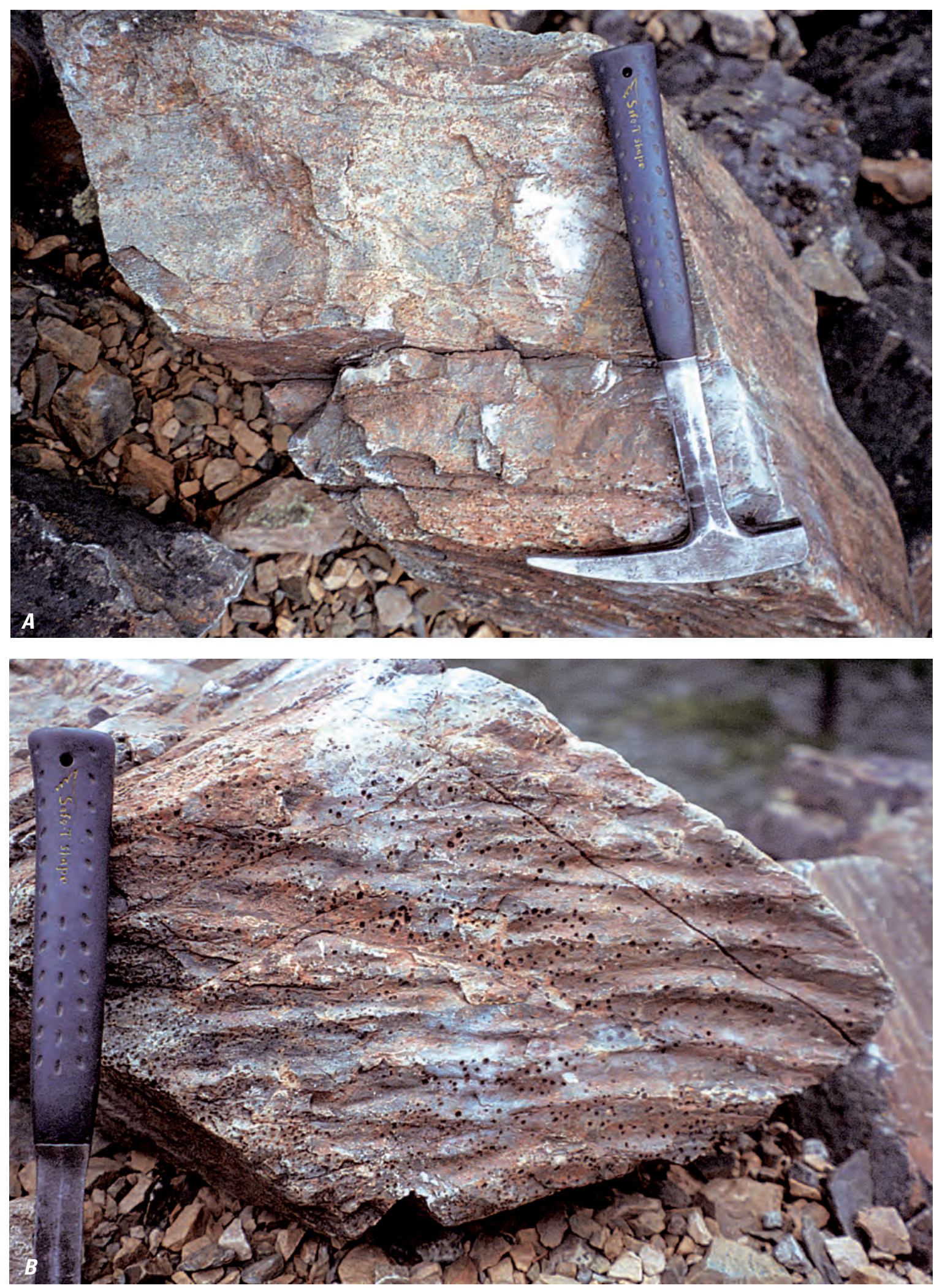

Figure B20. Mesoproterozoic metasandstone and quartzite of the Hoodoo Quartzite (Yh) from near Wilson Creek along Middle Fork Salmon River (eastern pl. 2). A, Lenticular bedding in metasandstone. Hammer (handle $30 \mathrm{~cm}$ ) for scale. $B$, Ripple marks in metasandstone. Hammer (handle $30 \mathrm{~cm}$ ) for scale. 

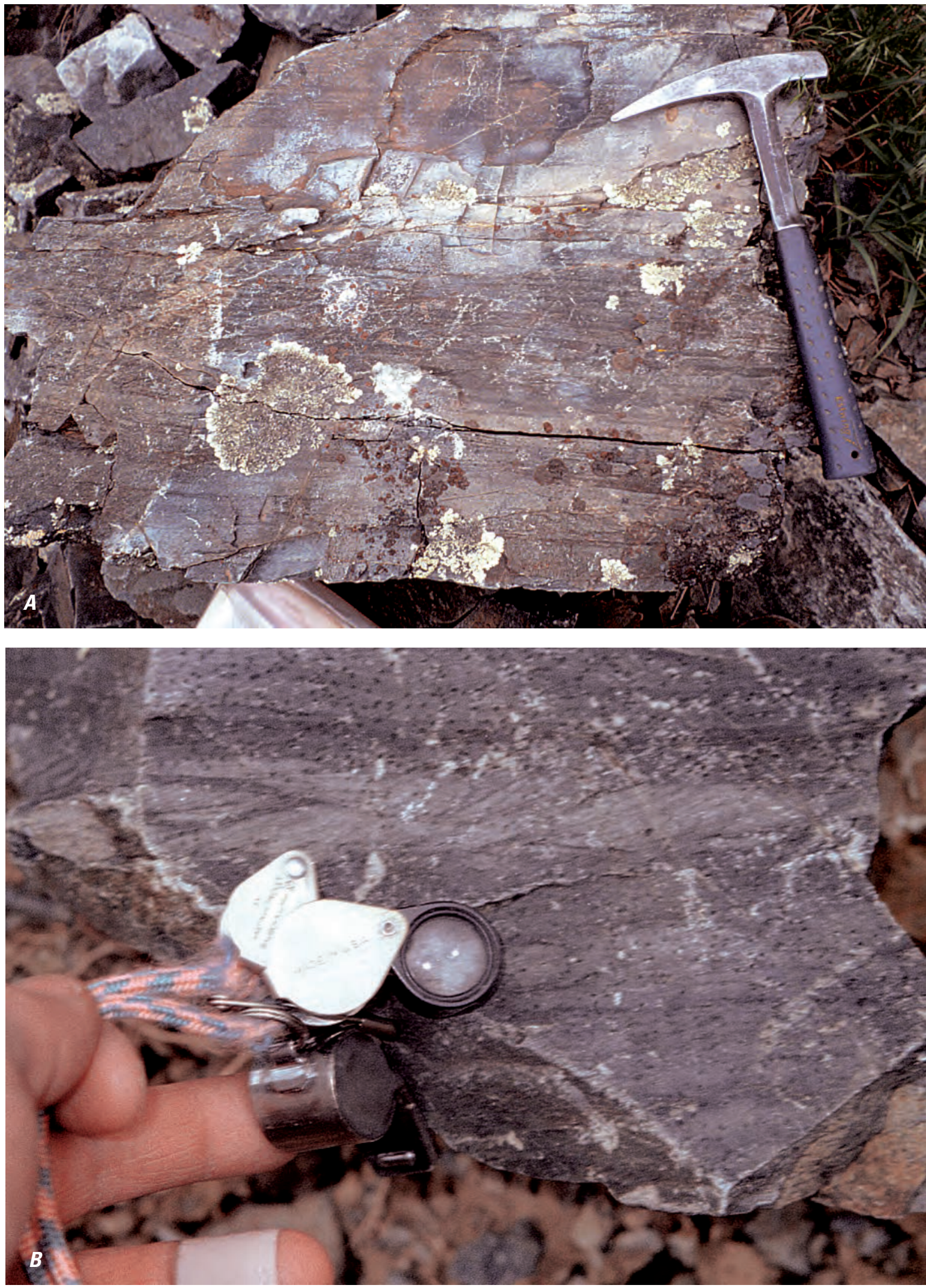

Figure B21. Mesoproterozoic siltite to schist of greenschist facies Yellowjacket Formation (Yy) from near Woolard Creek along Middle Fork Salmon River (eastern pl. 2). A, Preserved fine-scale lamination and bedding features. Hammer (handle $30 \mathrm{~cm}$ ) for scale. $B$, Preserved small-scale ripple cross lamination. Hand lenses (larger, $2.5 \mathrm{~cm}$ long) for scale. 
A.

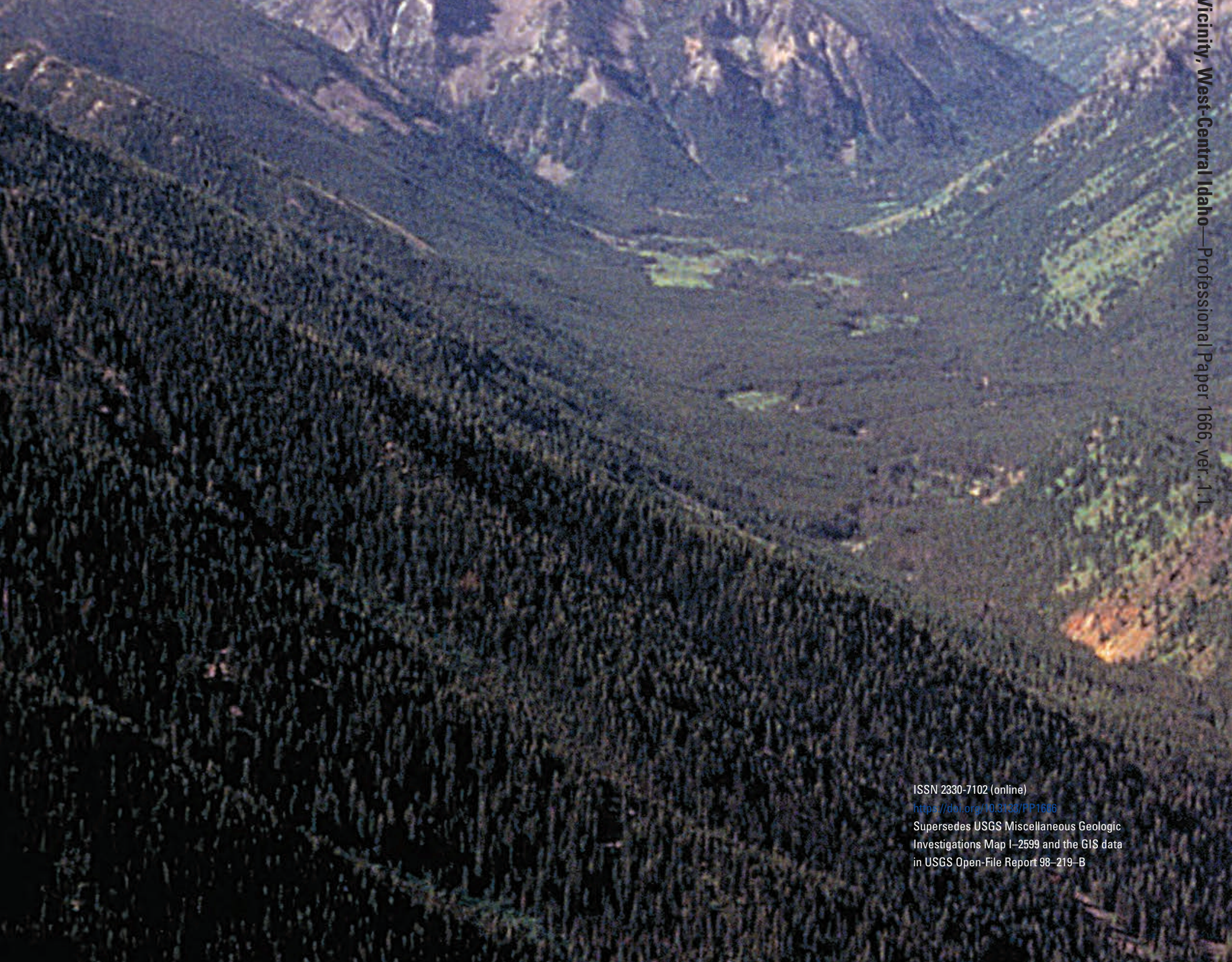

